UNIVERSIDADE DE SÃO PAULO

FACULDADE DE FILOSOFIA, LETRAS E CIÊNCIAS HUMANAS DEPARTAMENTO DE HISTÓRIA PROGRAMA DE PÓS-GRADUAÇÃO EM HISTÓRIA SOCIAL

TANIA MACHADO MORIN

PRÁTICAS E REPRESENTAÇÕES DAS MULHERES NA REVOLUÇÃO FRANCESA - 1789-1795

São Paulo 2009 
UNIVERSIDADE DE SÃO PAULO

FACULDADE DE FILOSOFIA, LETRAS E CIÊNCIAS HUMANAS

DEPARTAMENTO DE HISTÓRIA

PROGRAMA DE PÓS-GRADUAÇÃO EM HISTÓRIA SOCIAL

\title{
PRÁTICAS E REPRESENTAÇÕES DAS MULHERES NA REVOLUÇÃO FRANCESA - 1789-1795
}

\author{
Tania Machado Morin \\ Dissertação apresentada ao Programa de \\ Pós-Graduação em História Social do \\ Departamento de História da Faculdade \\ de Filosofia, Letras e Ciências Humanas \\ da Universidade de São Paulo, para a \\ obtenção do título de Mestre em História
}

Orientadora: Profa ${ }^{a}$. Dra. Laura de Mello e Souza

São Paulo

2009 
Ao Patrick,

amigo de todas as horas. 


\section{Agradecimentos}

Agradeço especialmente à minha mestra e orientadora Laura de Mello e Souza por sua orientação cuidadosa e dedicada. Sempre generosa com seu tempo, suas idéias, seus livros , a leitura minuciosa do texto, e as indicações de centros de pesquisa a consultar. Seu incentivo e amizade foram essenciais nesses três anos de trabalho.

Sou grata aos professores Modesto Florenzano, Leila Mezan Algranti, e Carlos Alberto Zerón pelas sugestões oportunas sobre a dissertação, interpretação de imagens e indicações bibliográficas, e à Leila Leite Hernandez pela idéia de estudar a iconografia da Revolução Francesa. Gostaria também de lembrar Philippe de Carbonnières pela acolhida simpática nos arquivos de gravuras do Museu Carnavalet em Paris, e Silvia Davy que prestou a ajuda técnica tão necessária na organização digital das imagens e apresentação do trabalho.

Uma palavra especial à Stephanie, minha filha, cujo trabalho sobre Olympe de Gouges despertou meu interesse pelo tema das mulheres revolucionárias, à minha mãe, por seu entusiasmo pela Revolução Francesa, ao meu pai, que fez a revisão da versão inicial do texto, e ao Patrick, meu marido, que acreditou no projeto e me ajudou a superar as dificuldades do caminho. Muito importante também foi o carinho dos amigos que me acompanharam com interesse nessa trajetória. 


\section{Resumo da Dissertação}

O tema desta dissertação de mestrado é a controvérsia sobre os direitos civis e políticos das mulheres na França revolucionária, suscitada pela atuação cívica vigorosa das militantes políticas nos seis primeiros anos da Revolução - 1789-1795. Essas mulheres adquiriram uma visibilidade dramática ao participar maciçamente do movimento revolucionário, organizar-se em clubes políticos e exercer na prática alguns dos direitos de cidadania reservados ao sexo masculino. Seus direitos cívicos foram recusados, mas, pela primeira vez o assunto foi debatido e as autoridades tiveram que justificar a exclusão publicamente. O objetivo da pesquisa é estudar como as mulheres do povo conseguiram participar tão ativamente da vida política nacional no período inicial da Revolução e as razões pelas quais foram afastadas da cena pública. Estudarei a questão através das categorias práticas e representações, focalizando a atuação das militantes, e as imagens de mulheres nos espaços públicos e privados. Três grupos femininos emblemáticos serão considerados: as mães republicanas, as militantes políticas e as mulheres-soldados. A militância será analisada em duas vertentes principais: as jornadas revolucionárias começando pela Marcha a Versalhes em 1789 e a atuação de clubes femininos como a Sociedade das Republicanas Revolucionárias. As ativistas foram derrotadas junto com o último levante popular em Prairial do ano III. Razões políticas e culturais explicam porque as mulheres foram mal recebidas na arena política nacional. O capítulo da Iconografia apresenta 37 imagens de alegorias, caricaturas e cenas de acontecimentos da Revolução que ajudam a compreender o comportamento que se esperava das mulheres decentes: a maternidade com a dimensão cívica da educação dos futuros patriotas e a dedicação exclusiva ao lar. A moral republicana exigia que cada um cumprisse o seu papel na família e no corpo político. Era preciso manter a diferenciação das funções dos sexos: as mulheres deviam governar a casa e os homens o país. As militantes queriam ser mulheres livres, armarse, agir com independência , mas a maioria dos homens achava que eram usurpadoras das atribuições masculinas. A iconografia mostra modelos de comportamentos femininos virtuosos: deusas representando a nação porque estavam acima dos conflitos ou mães abnegadas, caridosas e heróicas. As que freqüentavam as tribunas das assembléias se transformavam nas terríveis "tricoteiras". As militantes foram toleradas enquanto foram úteis - quando fizeram oposição aos jacobinos foram reprimidas em nome dos princípios morais que sustentavam a República.

\section{Palavras chave: mulheres, Revolução Francesa, militantes, iconografia.}




\begin{abstract}
The subject of this Master's thesis is the controversy about civil and political rights of women in revolutionary France, sparked by the vigorous female militancy in the early years of the Revolution - 1789-1795. These women became dramatically visible when they massively joined the revolutionary movement, organized in political clubs and exercized some exclusively male citizenship rights. Their political rights of citizenship were denied, but for the first time the issue was debated and government officials had to publicly justify their decision. The objective of this research is to study how working-class women managed to participate so actively in national politics in the initial period of the Revolution and the reasons that led to their being banned from the public scene. I will explore the subject from the perspective of women's practices and representations, meaning the militants' civic actions and women's images in the public and private spheres. This paper will focus on three main groups of women: republican mothers, political activists and women soldiers. Their political involvement will be considered from the standpoint of their participation in insurrectionary journées, such as the March to Versailles, and membership in women's political clubs, such as the parisian Society of Revolutionary Republicans. The militant citoyennes were defeated in the last popular uprising of Prairial, Year III. Political and cultural factors explain why women's intervention in national politics was not welcomed. The chapter on representations discusses a repertoire of 37 alegories, caricatures and revolutionary events that help understand the kind of behaviour expected of decent women: civic motherhood, whose aim was to nurture and educate future patriots and an exclusive devotion to domestic duties. Republican morals required that everyone fulfilled their proper role in the family and in public life. It was necessary to maintain the cultural norms of gender differentiation : women managed the household and men ruled the country. Militants wanted to be "free women", that is, bear arms, and act independently, but most men thought that activists were "stepping out of their sex" and usurping male roles. The iconography fosters virtuous feminine behaviour: lofty goddesses representing the nation because they stood above conflict; or self-sacrificing, charitable and heroic mothers. The women who regularly attended the Assembly galleries became despicable "knitters". Militant women were tolerated while useful but when they became political adversaries, they were repressed in the name of the essential moral principles of the Republic.
\end{abstract}

Keywords: women, French Revolution, militants, iconography. 


\section{SUMÁRIO}

\section{Introdução}

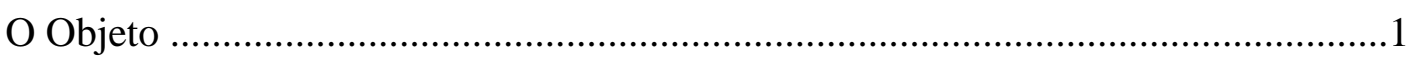

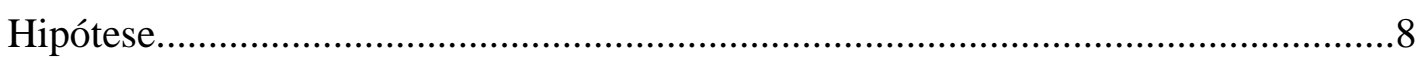

Diálogo com a historiografia.............................................................................. 12

Capítulo 1 - O ativismo das mulheres no espaço público: 1789-1795......................24

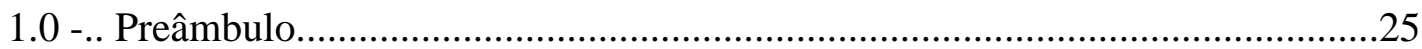

1.1 - Aspirações das mulheres :Cahiers de Doléances (Cadernos de Queixas) .........25

1.2 - A República da Virtude......................................................................................

1.3 - A conquista do espaço moral....................................................................................3.

1.4 - A ruptura com o passado.....................................................................................36

1.5 - A maternidade cívica ………………………………………………………....40

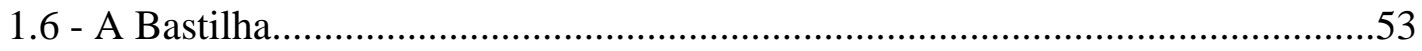

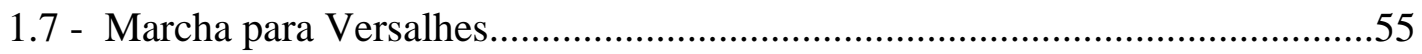

1.7.1 - Antecedentes sociais e políticos da Marcha.............................................55

1.7.2 - Motivações da Marcha............................................................................58

1.7.3 - Repercussões da Marcha..........................................................................63

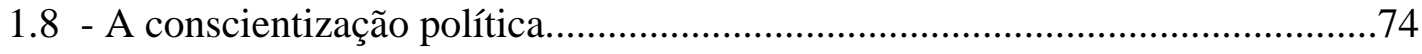

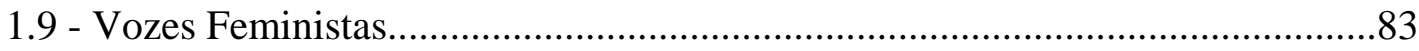

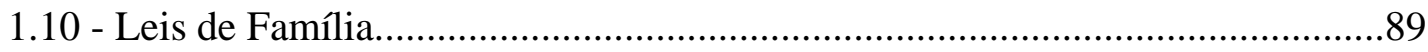

1.11 - Militância Organizada........................................................................................94

1.11.1 - Clubes Femininos nas Províncias.............................................................95

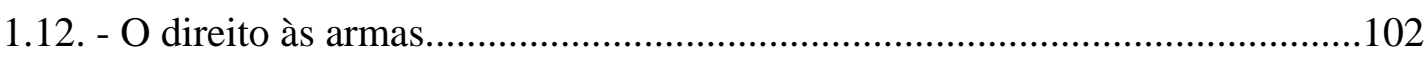

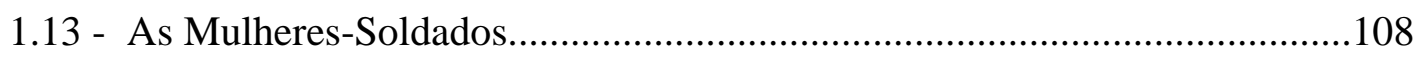

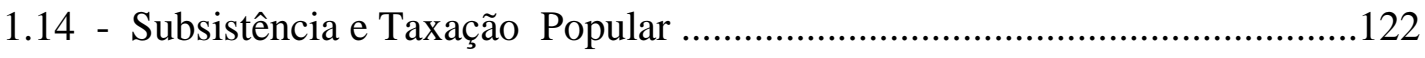

1.15 - A Sociedade das Cidadãs Republicanas Revolucionárias................................127

1.16 - A guerra das cocardas................................................................................141

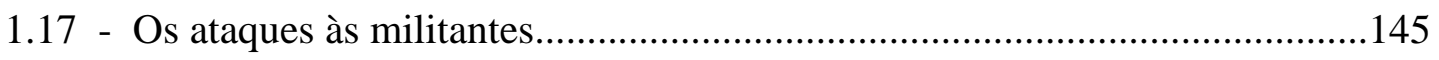

1.18 - A supressão da Sociedade das Cidadãs Republicanas Revolucionárias ......150

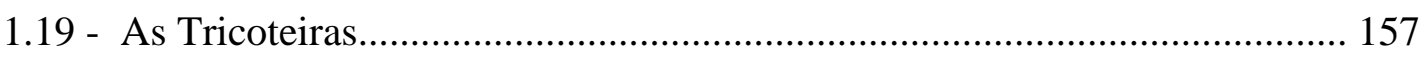

1.20 - As insurreições de Germinal e Prairial do Ano III ...........................................160 


\section{Capítulo 2 - Representações femininas}

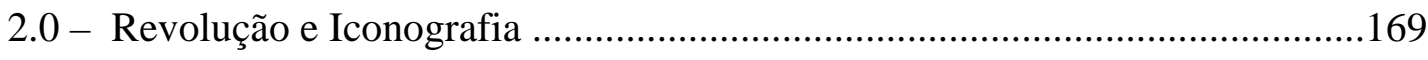

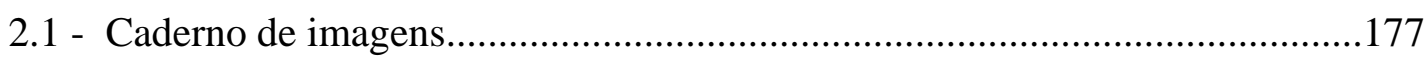

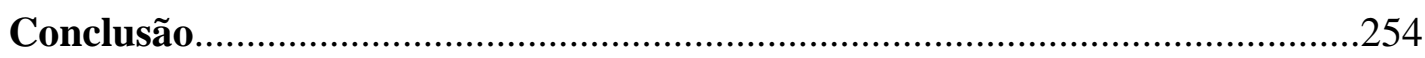

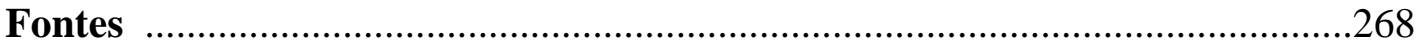

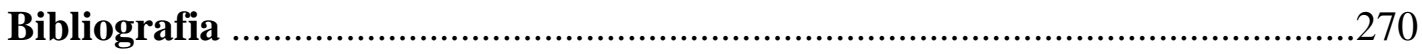

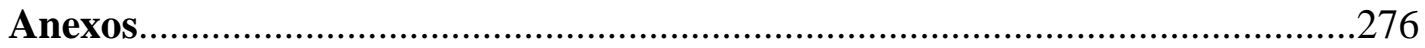




\section{LISTA DE ILUSTRAC̄̃̃ES}

\section{Capítulo 1:}

Mapa das Associações Políticas de Mulheres (ou Clubes) e Sociedades Populares Mistas (1789-1793) na França.

\section{Capítulo 2:}

1 - A Nova Praça da Bastilha.

2 - A Pátria instrui seus filhos e recebe a todos em seu seio...

3 - A República.

4 - A Igualdade.

5 - O Pudor.

6 - A França Republicana abrindo seu seio a todos os franceses.

7 - A Alegoria da Liberdade.

8 - Professora Republicana.

9 - A Fonte da Regeneração - visão de conjunto.

10 - A Fonte da Regeneração - detalhe da Fonte.

11 - A Natureza.

12 - Uma jovem havia prometido...

13 - Família indo para a guinguette

14 - Partida para a fronteira de um cidadão voluntário....

15 - Partida do voluntário.

16 - A heroína de Milhier.

17 - Os bandidos matam um pai nos braços de sua filha...

18 - Plantação da árvore da Liberdade.

19 - As cidadãs de Paris, esposas de artistas...

20 - "Vendedoras do mercado (Dames de la Halle) parabenizando..."

21 - Amazona Nacional.

22 - As Francesas se tornam livres.

23 - As mulheres-soldado.

24 - A Versalhes, a Versalhes.

25 - O $4^{\circ}$ acontecimento de 5 de outubro de 1789. 
26 - Jornada memorável de Versalhes na $2^{\text {a }}$ feira, 5 de outubro de 1789.

27 - Dia 1 de Prairial do Ano III (1795) - detalhe ampliado.

28 - Dia 1 de Prairial do Ano III (1795) - desenho completo.

29 - Clube patriótico de mulheres.

30 - Clube das mulheres patriotas numa igreja.

31 - As tricoteiras jacobinas ou de Robespierre.

32 - As tricoteiras da guilhotina nos degraus...

33 - O jantar do diabo.

34 - A grande debandada.

35 - A República.

36 - A Loucura dos homens.

37 - A mulher com o mosquete e o homem com a roca 


\section{INTRODUÇ̃̃O}

\section{O objeto}

O tema desta dissertação de mestrado é a controvérsia sobre os direitos civis e políticos das mulheres na França revolucionária, suscitada pela atuação cívica vigorosa das militantes políticas nos primeiros anos da Revolução. Os princípios revolucionários de justiça, igualdade, e os valores morais que levariam à regeneração da sociedade entusiasmaram o componente feminino das classes populares, as quais manifestaram o desejo de participar das grandes mudanças que conduziriam à "felicidade da humanidade"1. As circunstâncias fluidas e as incertezas do início da Revolução abriram um espaço de expressão política a um grupo social antes excluído dele. Fatores econômicos e políticos motivaram os primeiros protestos femininos em 1789. Na Revolução, a escassez de gêneros adquiriu conotações políticas ${ }^{2}$. Luís XVI se recusava a aceitar os decretos aprovados pela Asssembléia Nacional no mês de agosto, entre eles a importante Declaração dos Direitos do Homem e do Cidadão. Pressionadas pela crise de subsistência, e indignadas com a atitude do Rei, as mulheres do povo se fizeram ver e ouvir de forma dramática a partir de setembro de 1789: "elas irromperam maciçamente na cena política, focalizando os olhares sobre elas como grupo de mulheres, pela primeira vez na história revolucionária, esboçando os traços de uma prática feminina revolucionária, revelando a existência ds relações entre homens e mulheres dentro do movimento revolucionário" ${ }^{3}$.

Como foi possível que mulheres com pouca instrução, teoricamente sem experiência de articulações políticas, conseguissem participar tão intensamente do movimento revolucionário de 1789 a 1795? Pretendo estudar de que maneiras aquelas ativistas puderam instruir-se politicamente, encontrar apoio entre os companheiros dos meios populares e usar em seu proveito os novos espaços criados

\footnotetext{
1 Citação da obra Les Femmes dans la Révolution, Edhis, Paris, 1982, 3 vols ; Cahiers de Doléances de Femmes et autres textes, Editions des Femmes, Paris, 1981 IN GODINEAU, Dominique, Citoyennes Tricoteuses - Les femmes du peuple à Paris pendant la Révolution Française, Paris, Editions Alinea, Perrin, 2004 , p. 111.

2 LAPIED, Martine, « Histoire du Genre en Révolution » IN La Révolution à l'oeuvre - perspectives actuelles dans l'histoire de la Révolution Française, Paris, Presses Universitaires de Rennes, 2005, p. sem numeração, ver subtítulo : «Une histoire du terrain ».

${ }^{3}$ GODINEAU, Dominique, Citoyennes Tricoteuses - Les femmes du peuple à Paris pendant la
}

Révolution Française, Paris, Editions Alinea, Perrin, 2004 , p.110. 
pela Revolução. Quais eram suas preocupações, que motivos as levaram a tomar parte das jornadas revolucionárias, organizar-se em clubes políticos mistos e femininos, e exercer na prática alguns dos direitos de cidadania reservados ao sexo masculino? Examinarei a questão dos atos de cidadania praticados por aquelas que queriam ser chamadas de cidadãs, sem no entanto posssuir os direitos formais da cidadania. É preciso refletir sobre o sentido do discurso e da prática política das mulheres "sans-culottes" que se transformaram em militantes revolucionárias, assim como a repercussão que tiveram na sociedade. A percepção que essas protagonistas tinham de seu papel na nova ordem social não necessariamente coincidiu com as expectativas masculinas em geral sobre o lugar apropriado da mulher na sociedade francesa.

O objeto da pesquisa, portanto, é a militância feminina das classes populares, e o modo como suas ações foram recebidas pela sociedade e pelos líderes políticos. Apresentarei algumas vozes de feministas avant-la-lettre, como Olympe de Gouges , Théroigne de Méricourt e Etta Palm d'Aelders, idealistas que perceberam e denunciaram o tratamento desigual reservado às mulheres na França. Essas ativistas se notabilizaram pelas propostas audaciosas, mas não tiveram eco popular significativo. Por essa razão, darei mais ênfase àquelas que fundaram clubes femininos e tiveram uma ação limitada no tempo, porém mais conseqüente para o curso da Revolução e para o futuro político das mulheres francesas. $\quad$ Refiro-me à Sociedade das Republicanas Revolucionárias que construiu uma rede de apoio político entre as sociedades populares e Seções de Paris dominadas pela sans-culotterie. Agiam como membros do clube ou integradas nas massas revolucionárias. Pretendo refletir sobre sua atuação cívica , e seu sentimento de pertencimento ao Povo Soberano. Como parte desse corpo político, fizeram uso de alguns direitos tais como a apresentação de petições e reunião em associações ${ }^{4}$. Poucas reivindicaram as prerrogativas da cidadania , mas achavam que tinham o direito de expressar suas opiniões e fiscalizar o cumprimento das leis.

\footnotetext{
${ }^{4}$ LAPIED, Martine, « Histoire du Genre en Révolution » IN La Révolution à l’oeuvre - perspectives actuelles dans l'histoire de la Révolution Française, Paris, Presses Universitaires de Rennes, 2005, pp.4-5.
} 
Discutirei a reação dos líderes políticos ao ativismo feminno popular, para compreender de que forma o discurso e as ações das militantes provocaram o debate sobre a emancipação política das mulheres. A questão foi colocada na ordem do dia em outubro de 1793 e o sufrágio feminino foi recusado, o que não chega a surpreender, considerando a longa tradição de mando masculino na França, onde, em 1789, ainda vigorava a Lei Sálica. Como bem aponta Lynn Hunt, o novo na atitude dos revolucionários não foi a recusa, e sim “o fato de terem tido que discutir publicamente o papel das mulheres e justificar sistematicamente, e pela primeira vez, a exclusão das mulheres da coisa pública”5 . Antes da Revolução, nenhuma explicação teria sido necessária.

Para analisar as razões do repúdio aos direitos cívicos femininos, precisamos considerar tanto as circunstâncias políticas quanto as tradições culturais. Derrotadas politicamente, as militantes passaram a simbolizar o modelo negativo de comportamento feminino. As representações iconográficas, principalmente as caricaturas, são impiedosas com as ativistas, e apontam aspectos instigantes da questão, relacionada com a redefinição das atribuições de homens e mulheres no contexto da regeneração da sociedade. Com a exceção das heroínas de Versalhes, que foram homenageadas até 1793, e mesmo assim, com bastante ambiguidade, como assinalarei no Capítulo 1, a maioria dos líderes revolucionários preferia exaltar as mães republicanas, que consideravam, numa visão maniqueísta, o "reverso da medalha" das mulheres politizadas. O conceito de maternidade cívica fazia parte do ideário revolucionário da "sociedade virtuosa", e por isso será necessário refletir sobre o que significavam os conceitos de virtude e regeneração do homem para aqueles cidadãos e cidadãs. Este estudo é permeado pela questão dos modelos de comportamento femininos e moral republicana, e assim sendo, estudarei o contraste entre as mães e as "mulheres livres" - mas neste particular, os documentos nos reservam surpresas, como procurarei demonstrar no desenvolvimento do trabalho.

Analisando os protestos e as ações femininas, surgem questões como a natureza das insatisfações e aspirações das mulheres no início da Revolução, e não só das

\footnotetext{
${ }^{5}$ HUNT, Lynn , " L'histoire des femmes: accomplissements et ouvertures " IN LAPIED, Martine e PEYRARD Christine (direction) Préface VOVELLE, Michel, La Révolution Française au Carrefour des Recherches , Aix-en Provence, Publications de l’Université de Provence, 2003
} 
classes populares. A leitura dos Cahiers de Doléances (Cadernos de Queixas das Mulheres) nos dão algumas respostas de diferentes grupos sociais femininos, como religiosas, comerciantes, burguesas, floristas e mães de família. Há algumas preocupações comuns entre as autoras dessas cartas e as militantes: a reivindicação de educação profissional para as mulheres poderem ganhar a vida e terem mais independência, a necessidade da lei do divórcio, a igualdade perante a lei para os dois sexos. E já se percebe ali uma consciência política bem desenvolvida. Mas, de que maneira esse tipo de consciência surgiu e se disseminou entre as classes populares, e as mulheres passaram das idéias à ação?

Seguindo a trajetória das ativistas, vemos que lutaram ao lado dos homens no movimento popular urbano, participaram de várias jornadas populares como as de 9 de abril, 20 de junho e 10 de agosto de 1792, as quais resultaram na queda da monarquia. Abraçaram a Revolução, queriam armar-se para defender a nação dos inimigos internos, e tomaram parte das festas cívicas. Algumas se alistaram no exército e foram lutar nas fronteiras. No caso das Republicanas Revolucionárias, durante certo tempo contaram com o apoio dos deputados Montagnards (Montanheses) e os ajudaram a derrubar os Girondinos. Nessa ocasião, mereceram elogios públicos, como veremos no próximo capítulo. Depois se aliaram aos radicais Enragés e fizeram oposição aos Montagnards. As militantes adquiriram uma visibilidade nunca antes imaginada para mulheres do povo, despertando o interesse e a inquietação de integrantes do governo acerca da questão dos direitos civis e políticos femininos. A pergunta que fica é: porque sua presença na cena política foi tolerada e até incentivada no início da Revolução, porém reprimida em outubro de 1793, e depois novamente, e de forma definitiva, em 1795? Havia líderes revolucionários favoráveis aos direitos cívicos das mulheres? Se os havia, por que não os defenderam na Convenção?

Em compensação, em matéria de direitos civis, os legisladores foram modernos: houve avanços muito relevantes no caminho da emancipação civil da mulher, com a aprovação da lei do divórcio (que era uma reivindicação feminina), o fim dos privilégios masculinos da primogenitura nas heranças familiares e concessão de mais autonomia jurídica à mulher. Pela lógica do “espírito revolucionário”, os mesmos argumentos de eqüidade, liberdade e reciprocidade entre os cidadãos se aplicariam aos direitos cívicos femininos. Alguns dos dirigentes mais ativos da Revolução, como St. 
Just, pensaram na articulação entre a promoção civil da mulher e seu papel político ${ }^{6}$. Por que não deram o próximo passo, reconhecendo a igualdade entre cidadãos e cidadãs também na esfera política?

De acordo com Dominique Godineau ${ }^{7}$, para compreender o significado da história da luta pela cidadania feminina, precisamos articular diferentes campos historiográficos, como a história do pensamento político, a história social das práticas políticas e a história cultural das representações. Considerando todos esses aspectos, julguei que a abordagem mais instigante para estudar o objeto da pesquisa e responder às perguntas enunciadas, seria através das categorias práticas, entendidas aqui como as experiências reais, ações realizadas e " modo de agir característico de determinado grupo", segundo definição do dicionário Houaiss ${ }^{8}$, e representações das mulheres na Revolução Francesa. As representações consideradas neste estudo são as iconográficas, e mais especificamente as imagens femininas e masculinas que integram um sistema cultural de representações em construção durante a Revolução ${ }^{9}$. Reuni para este trabalho algumas representações significativas de mulheres e homens nos espaços públicos e privados, relevantes para a compreensão das questões enunciadas. A seguir explicarei mais detalhadamente o que entendo por práticas e representações para os objetivos da dissertação.

Alguns conceitos não se referem necessariamente à categoria práticas, mas são úteis para pensar as ações políticas femininas: Roger Chartier ${ }^{10}$ assim se referiu à festa: "Com seus rituais, seus gestos, seus objetos, ela é uma gramática simbólica que, fazendo ver e ouvir, permite enunciar um projeto político". Aplicando essa idéia à militância feminina, pode-se pensar que foi posta em prática pelas ativistas que

\footnotetext{
${ }^{6}$ GUIBERT-SLEDZIEWSKI, Elizabeth , "La femme, objet de la Révolution », Síntese de duas comunicações feitas na Assembléia da Société des Études Robespierristes, em junho 1984, e no Collège International de Philosophie, seminário "Formes du féminisme historique”, G. Fraisse, em abril de 1986, pp. 10-12.

${ }^{7}$ GODINEAU, Dominique, « Histoire sociale, histoire culturelle, histoire politique : la question du droit de cité des femmes » IN LAPIED, Martine e PEYRARD Christine (direction) Préface VOVELLE, Michel, La Révolution Française au Carrefour des Recherches, Aix-en Provence , Publications de l’Université de Provence, 2003, p. 302.

${ }^{8}$ Dicionário Houaiss da língua portuguesa, Rio de Janeiro, 2001, p. 2278.

${ }^{9}$ GODINEAU, Dominique, " Histoire sociale, histoire culturelle, histoire politique : la question du droit de cité des femmes " IN LAPIED, Martine e PEYRARD Christine (direction) Préface VOVELLE, Michel, La Révolution Française au Carrefour des Recherches, Aix-en Provence , Publications de l’Université de Provence, 2003, pp. 294, 295.

${ }^{10}$ CHARTIER,Roger, Lectures et lecteurs dans la France d'Ancien Régime, Paris, Ed. du Seuil, p. 36.
} 
souberam utilizar gestos, rituais e discursos para manifestar seu projeto de integração à cidadania. Ainda Chartier: " (...) é preciso postular que existe uma distância entre a

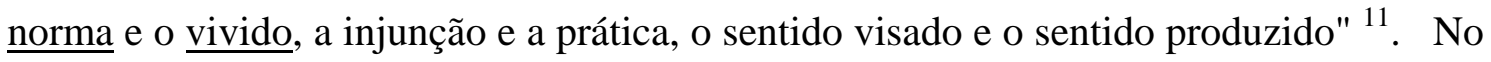
caso das ativistas, a "norma" não as incluía no grupo dos cidadãos ativos com plenos direitos de cidadania, mas o "vivido" nos mostra aquelas mulheres praticando atos de cidadania que as incluíam no povo soberano. A lei era rígida, a prática criava alternativas. Quanto ao "sentido visado e o sentido produzido" é essencial discutir a diferença entre os dois, e refletir sobre as intenções das mulheres e as repercussões produzidas na sociedade.

A obra de Dominique Godineau mostrou a pluralidade das ações concretas realizadas pelas mulheres nos espaços abertos pela Revolução ${ }^{12}$ e Lynn Hunt aponta a nova ênfase historiográfica sobre as práticas de pessoas comuns, e oferece sua definição de democracia: " Ela é menos uma forma de governo que um conjunto de práticas que todos os franceses e francesas aprendiam durante a Revolução, fossem eles brancos ou negros, emancipados ou escravos, soldados ou civis"13 (grifo meu).

Capítulo 1 tratará da pluralidade dessas práticas e o sentido que tiveram para as mulheres e para os líderes da Revolução. Três grupos femininos emblemáticos serão estudados: as mães republicanas, militantes políticas e as mulheres-soldados. A separação por categorias foi adotada com o intuito de organizar melhor o trabalho, e não reflete comportamentos estanques ou mutuamente excludentes. Ao contrário, numa época de ruptura com o passado e redefinição dos papéis sociais, percebe-se um entrelaçamento de papéis e funções que escapam a definições rígidas.

As representações (Capítulo 2), num sentido abrangente, tornam visível o que é imperceptível ou intensificam e complementam uma presença real. Assim compreendidas, as representações são realizadas através de signos - imagens, símbolos ou emblemas - que têm uma relação analógica com o referente, como no caso de retratos, cenas de acontecimentos (événementielles) ou não, como no caso das

\footnotetext{
${ }^{11}$ idem, p. 15.

${ }^{12}$ Tema de vários artigos em revistas acadêmicas e capítulos em obras coletivas, e do trabalho mais abrangente sobre a participação das mulheres do povo na política revolucionária, o livro já citado Citoyennes Tricoteuses.

${ }^{13}$ HUNT, Lynn, « Relire l’histoire du politique », idem, p. 121.
} 
alegorias, emblemas e símbolos. Annie Jourdain, em sua obra sobre a história da representação no final do século das Luzes, pondera que vários pensadores, entre eles Jean-Jacques Rousseau e Condillac, julgavam que os signos eram essenciais quando se empreendia a "modificação" dos homens, pois consideravam que a organização humana só podia ser "modificada" e aperfeiçoada pela educação ${ }^{14}$. Assim sendo, estavam persuadidos do poder dos signos - gestuais, de linguagem ou de imagens sobre a formação das idéias. Rousseau disse a esse respeito: "fala-se melhor aos olhos que às orelhas". A imagem poder servir de apoio à linguagem, que é volátil, e pode até comunicar o indizível, e Rousseau, mais uma vez afirmou: "em um piscar de olhos, tudo é dito"15. Tais conceitos foram absorvidos e colocados em prática pelos sucessivos governos revolucionários, os quais promoveram uma revolução cultural, "republicanizando tudo", como queria o Abbé Grégoire ${ }^{16}$. Em vista de semelhante argumentação, pareceu-me que as representações iconográficas me ajudariam a compreender o papel da mulher como parte de um sistema cultural que tratou de redefinir as relações e as atribuições dos sexos na era revolucionária.

Ao discorrer sobre o conceito de representação, Raquel Stoiani pondera que : "seu significado é produto de uma série de interesses e manipulações, não correspondendo necessariamente à realidade concreta de onde deriva" ${ }^{17}$. As práticas levaram às representações? Havia um sistema cultural de representações que influenciava as práticas, e por outro lado , as práticas levaram a determinados tipos de representações. $\mathrm{O}$ uso e a disseminação de imagens politicamente construídas contribuiu para consolidar determinadas percepções das ações femininas na sociedade em geral. O uso repetido dessas representações criou, em alguns casos, estereótipos que perduraram nos manuais escolares e no imaginário coletivo até a época atual. A arte tinha um papel pedagógico e inspirador, e os artistas que recebiam encomendas

\footnotetext{
14 JOURDAIN, Annie - Les Monuments de la Révolution - 1770-1804 - Une histoire de la représentation Paris, Honoré Champion Editeur, 1997, pp. 10-12. .

${ }^{15}$ Estas considerações estão em ROUSSEAU, Oeuvres complètes, Paris, 1954-1995; L'Emile, IV, p. 647-649; Essai sur l'origine des langues, V, pp. 376-378; "Rousseau et le pouvoir des signes. Représentation et nation" In "J.J. Rousseau, politique et nation " (IIe Colloque International de Montmorency 1995) IN JOURDAIN, Annie - Les Monuments de la Révolution - 1770-1804 - Une histoire de la représentation Paris, Honoré Champion Editeur, 1997, pp. 9-12.

${ }^{16}$ Ver a citação do A. Grégoire em "Revolução e iconografia", no Capítulo 2.

${ }^{17}$ STOIANI, Raquel, Da Espada à Águia - Construção Simbólica do Poder e Legitimação Política de Napoleão Bonaparte, São Paulo, Humanitas, 2005, p. 21.
} 
do governo revolucionário eram, por assim dizer, "instituidores da nação" ${ }^{18}$. objetivo dessa produção artística era criar imagens que ensinassem e convencessem a nação a abraçar os novos valores cívicos ancorados na moral e nos bons costumes.

Trabalharei principalmente com dois gêneros artísticos, as alegorias e as caricaturas, além de algumas aquarelas do artista Lesueur, qualificadas pelo Museu Carnavalet como "crônica em imagens da Revolução francesa"19. As caricaturas ilustravam o humor do momento e o conflito, enquanto a alegoria, corporificando idéias abstratas, os atenuava e apagava. Em geral, pensamos nas caricaturas como imagens satíricas ou exageradas e nas cenas históricas como registro objetivo de fatos. As imagens que sobreviveram da Revolução sugerem, entretanto, como é difícil manter essa divisão clara, e um bom exemplo é a coleção de Lesueur, a meio caminho entre caricatura e o documentário, ou imagem "événementielle" (dos acontecimentos). Da mesma forma que as caricaturas, os documentários do período são representações altamente codificadas e estilizadas dos acontecimentos que retratam. Ambas possuem uma função comemorativa, mostrando personagens históricas do ponto de vista de classes ou grupos sociais específicos, por exemplo, as mulheres do ponto de vista dos homens. Ambas, portanto, constroem seus materiais tanto quanto os registram. ${ }^{20} \mathrm{~A}$ apresentação da iconografia tem o objetivo de extrair informações das imagens, ilustrar e observar a complementaridade ou discordância em relação à documentação escrita.

O recorte cronológico e espacial privilegiado é a cidade de Paris, de 1789 a 1795, pois esses foram os anos e o lugar de participação feminina mais marcantes da era revolucionária. Embora o palco principal da ação seja a capital francesa, mencionarei também outros grupos ou clubes políticos de mulheres relevantes nas províncias.

\footnotetext{
${ }^{18}$ JOURDAIN, Annie, « Les concours de l'An II - En quête d'un art républicain » IN La Révolution à l'oeuvre - perspectives actuelles dans l'histoire de la Révolution Française, Presses Universitaires de Rennes, 2005, p. 273.

${ }^{19}$ CARBONNIĖRES, Philippe de , Lesueur - Gouaches Révolutionnaires - Collections du Musée Carnavalet, Paris, Paris-Musées, 2005, p. 21.
}

${ }^{20}$ LEVINE, S. -"“Print Culture in the Age of the French Revolution" - IN Representing Revolution, IN LANDES, Joan - Visualizing the Nation - Cornell University Press - 2003. p. 181 
Na conclusão, as respostas finais às perguntas formuladas na problemática : quais eram os objetivos das ativistas políticas, quais foram suas práticas, e por que razões políticas, sociais, culturais sua participação política foi reprimida em parte em 1793 e categoricamente em 1795?

Todas as traduções de citações e documentos são minhas, exceto nos casos de obras estrangeiras publicadas em português, conforme constam das notas de rodapé e da bibliografia no final da dissertação.

\section{$\underline{\text { A hipótese }}$}

As mulheres da Revolução, inclusive as ativistas políticas, concordavam com a idéia da reforma dos costumes e da moralização da sociedade francesa. Acompanharam os homens no desejo de ruptura com os hábitos do Antigo Regime. Muitas achavam, como seus companheiros, que as mulheres tinham sido fúteis e levianas no passado. Olympe de Gouges, por exemplo, escreveu:

as mulheres fizeram mais mal que bem. As restrições e a dissimulação eram seu destino. O que lhes faltava em força física era compensado pela esperteza. ; elas se valeram de todos os recursos de seus charmes, e mesmo o (homem) mais impecável não lhes resistia (...) O governo francês, sobretudo, dependeu durante séculos da administração noturna das mulheres ${ }^{21}$.

O novo modelo de virtude republicana pregava o inverso: a dedicação à família, a austeridade, a transparência, o amor à pátria e a cooperação com o bem comum em detrimento dos interesses particulares. As militantes compreenderam aqueles elevados ideais e se esforçaram para vivê-los. Não devemos subestimar o poder daquelas idéias novas na primeira fase da Revolução, no caso, até 1793. Algumas chegaram a arriscar suas vidas entrando para o exército onde lutaram na guerra junto com seus maridos, pais e irmãos, ou se alistaram sozinhas. Muitas reuniram-se em clubes políticos mistos ou só de mulheres em Paris e nas províncias, e freqüentavam as galerias das assembléias para educar-se politicamente e poder contribuir com causas

\footnotetext{
${ }^{21}$ MOUSSET, Sophie, Olympe de Gouges et les droits de la femme, Editions du Félin, 2007, pp. 96-97.
} 
públicas. Assim, pode-se dizer que adotaram o discurso masculino: colocaram em prática os princípios republicanos. E o fizeram porque acreditaram que dessa forma estavam contribuindo para a felicidade do conjunto da nação. Sentiram-se incluídas no povo soberano e protegidas pela Declaração dos direitos do homem e do Cidadão. Participaram da vida pública porque, agindo como cidadãs, este era seu direito e seu dever, e sua prática tinha o sentido político de integrá-las nos assuntos da cidade. Ao mesmo tempo, houve razões prementes de ordem material que deram ímpeto à ação política. Durante a Revolução, a escassez de pão e a carestia dos gêneros castigou principalmente as donas-de-casa das classes populares, as mais desprotegidas nos momentos de crise de subsistência.

Entretanto, o discurso moralizante dos revolucionários era ambíguo. Se por um lado repudiavam o uso dos atrativos femininos para fins políticos, como acontecia no Antigo Regime, não deixavam de incentivar esses mesmos meios para que as noivas, esposas e amantes da Revolução atraíssem seus homens para a causa republicana. ${ }^{22}$. Os limites entre o privado e o público se esmaeciam. A mulher se tornou o prêmio do cidadão patriota . E inversamente, o patriota merecia a mulher porque era republicano, e portanto virtuoso. O que era condenável antes, agora virou mérito, tudo dependia da opção política. A iconografia nos revela essa dinâmica, assim como certas declarações das jovens revolucionárias.

Por sua vez, as militantes procuraram agir com transparência e racionalidade republicanas na administração dos seus clubes políticos, em seus discursos nas assembléias. À medida que a prática e o discurso das mulheres se aproximavam dos ideais de virtude republicana - essencialmente masculinos - elas estavam agindo como os homens, no sentido positivo de "elevar-se" acima de seu sexo. Para os críticos das mulheres politizadas, "elevar-se" tinha um sentido negativo de "pretensão descabida". Suzanne Desan, historiadora que estudou os clubes provinciais, assinala que elas estavam se tornando mais racionais, menos influenciáveis, e imbuídas de espírito

\footnotetext{
${ }^{22}$ DESAN, Suzanne - “Constitutional Amazons: Jacobin Women's Clubs in the French Revolution” IN Re-creating Authority in Revolutionary France, edited by Bryant T. Ragan, Jr.and Elizabeth A. Williams, New Brunswick, New Jersey, Rutgers University Press, 1992, pp. 25-27.
} 
público $^{23}$. Indo um passo além, proponho que, ao deixar para trás o estereótipo da mulher inconseqüente, as militantes membros de clubes políticos de fato adquiriram uma atitude mais masculina, na medida em que abandonavam os supostos defeitos femininos. Mas a sua intenção não era comportar-se "como homens", nem "como mulheres": era pensar e agir como membros do povo soberano, independente de sexo, como indivíduos chamados a fazer a sua parte na reconstrução da nação. Elas partiam do pressuposto da racionalidade comum aos dois sexos, e da convicção de que o amor à pátria estava acima do sexo.

Para a sociedade do fim do século XVIII, ainda era inconcebível pensar as relações entre homens e mulheres em termos de igualdade. Mas abandonar as frivolidades não era um progresso? Não significava que a vaidade e o egoísmo tinham sido substituídos pelo espírito altruísta da República? Sim, mas com limites. A virtude republicana para a mulher girava em torno da fraqueza, sensibilidade e outras características "naturais" do sexo feminino, pensamento que era corroborado pela medicina da época, enunciado notadamente no influente compêndio do médico Pierre Roussel, Système Physique et Moral de la Femme (Sistema físico e moral da mulher), de 1775 .

Embora houvesse visões diferentes acerca da melhor maneira de colocar em prática os valores da República, essas tensões culturais, por si sós, talvez não tivessem originado as leis que proibiram os clubes femininos em outubro de 1793, tampouco os decretos de maio de 1795. Enquanto as ativistas, especialmente as Cidadãs Republicanas Revolucionárias de Paris, foram aliadas úteis dos jacobinos, eles conviveram com os clubes femininos e toleraram suas manifestações na Assembléia e nas ruas. No entanto, quando elas se tornaram adversárias políticas e quiseram por em prática o conceito de democracia direta, caro ao movimento sans-culottes ${ }^{24}$ passaram

\footnotetext{
${ }^{23}$ DESAN, Suzanne - "Constitutional Amazons: Jacobin Women's Clubs in the French Revolution” IN Re-creating Authority in Revolutionary France, edited by Bryant T. Ragan, Jr.and Elizabeth A. Williams, New Brunswick, New Jersey, Rutgers University Press, 1992, p. 29.
}

${ }^{24}$ Segundo Patrice Higonnet, o sans-culotte se situa num campo duplo: parisiense e revolucionário, social e político. Um documento de maio de 1793 define o sans-culotte por uma referência social: " É um ser que anda sempre a pé [...] e que mora modestamente com sua mulher e seus filhos, se os tiver, no quarto ou quinto andar". O sans-culotte típico não é o indigente dos quartos mobiliados (chambre garnie: a expressão denota penúria e tristeza), mas um artesão, um compagnon (categoria intermediária entre aprendiz e mestre), ou pequeno patrão. Um quarto dos comissários civis das Seções vivia de rendas; 
a ameaçar a hegemonia jacobina no governo. Nas insurreições de Germinal-Prairial de 1795, as mulheres instigaram os homens à rebelião e participaram de violências, inclusive no recinto da Convenção. As massas assim insufladas podiam abalar a estabilidade e a credibilidade do governo republicano.

No momento em que as militantes deixaram de ser apenas personagens excêntricas e barulhentas para se tornarem uma ameaça política, os governantes julgaram necessário reprimi-las com o rigor da lei e a força das armas. Assim, parece-me que foi a combinação dos fatores ideológicos, culturais e políticos que motivou a repressão dos direitos políticos das mulheres na França revolucionária. Esta é a hipótese que a presente dissertação pretende comprovar.

\section{Diálogo com a Historiografia}

As primeiras obras que li sobre as mulheres na Revolução Francesa foram Visualizing the Nation - Gender Representation and Revolution in EighteenthCentury France ${ }^{25}$ (Visualizando a Nação - Representação de Gênero e Revolução na França do século XVIII) e Women and the Public Sphere in the Age of the

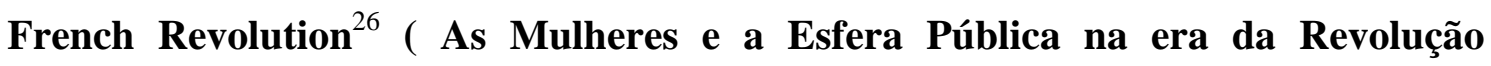
Francesa ), ambas da historiadora norte-americana Joan Landes. A primeira, Visualizing the Nation (2001) despertou meu interesse pelo tema dos usos das imagens femininas na construção da sociedade republicana, e da redefinição dos papéis dos gêneros tal como ocorreu na Revolução. Concordo com a autora em que as imagens valorizavam ou repudiavam comportamentos individuais tendo como referência os ideais coletivos. Noto, porém, que esses ideais eram "interpretados" pelos líderes jacobinos, no caso das gravuras encomendadas pelo governo

outros eram assalariados, criados domésticos ou pequenos comerciantes. Claire Lacombe, presidente do clube das Republicanas Revolucionárias, e o Enragé Jacques Roux aparecem no verbete como exemplos de integrantes da sans-culotterie. Informações IN HIGONNET, Patrice, FURET, Francois, e OZOUF, Mona, verbete "Sans-culotte" IN Dictionnaire Critique de la Révolution Française: Institutions et Créations, Événements, Idées, Acteurs - Champs, Flammarion 1992.

${ }^{25}$ LANDES, Joan B., Visualizing the Nation - Gender Representation and Revolution in EighteenthCentury France, Ithaca, Cornell University Press, 2001.

${ }^{26}$ LANDES, Joan B., Women and the Public Sphere in the age of the French Revolution, Ithaca and London, Cornell University Press, 1988. 
revolucionário. Por exemplo, o ideal republicano da boa mãe, que se sacrifica em nome de seus filhos e da nação, tem que ser constantemente reforçado, pois achava-se que a natureza feminina podia arrastar a mulher para uma independência perigosa. As ativistas políticas ficariam nesta segunda categoria. Essa é uma das explicações para a abundância de imagens de maternidade republicana durante a Revolução. Os revolucionários estavam dispostos inclusive a adotar as táticas de seus adversários católicos, pois estas tinham eficácia comprovada. Padres e revolucionários de todas as vertentes pregavam a domesticidade, a discrição, a dedicação ao próximo, a submissão ao marido. Landes desenvolveu uma argumentação instigante para mostrar que o desejo sexual masculino pelas imagens da vulnerabilidade, beleza e maternidade da mulher serviram para fortalecer os vínculos entre os cidadãos e a nação moderna representada por corpos femininos ${ }^{27}$. Tais explicações me parecem plausíveis, se considerarmos que Marianne, símbolo da República francesa, tem sido representada ao longo da história por protagonistas de grande beleza , como Brigitte Bardot e Catherine Deneuve.

Já a obra Women and the Public Sphere in the age of the French Revolution (1988) analisa a traumática exclusão feminina da esfera pública burguesa e masculina durante a Revolução. Para Landes, a queda das mulheres politicamente influentes no antigo Regime, as quais se destacaram no mundo aristocrático dos salões literários, está na raiz do feminismo moderno, que nada mais é do que a luta das mulheres para reingressar na esfera pública ${ }^{28}$. As salonnières ficaram associadas à frivolidade, ao luxo desmesurado, à dissimulação e aos vícios da aristocracia O discurso burguês em relação ao sexo feminino, ao contrário, influenciado principalmente pelas idéias de Rousseau e Diderot, pregava a transparência, a devoção à família, o classicismo, a volta das imaginadas virtudes das romanas antigas, como Cornélia e Pórcia. Para a regeneração dos costumes, a conduta das mulheres teria que ser a mais discreta possível, e suas vidas dedicadas à maternidade republicana. Conseqüentemente, a ausência das mulheres da esfera política não ocorreu por acaso. Landes pensa que, do ponto de vista feminino, o iluminismo foi um anti-iluminismo , e a Revolução, uma contra-revolução, e haveria razões para supor que os políticos revolucionários se

\footnotetext{
${ }^{27}$ idem, pp. 1 , 99, 170, 173.

${ }^{28}$ LANDES, Joan B., Women and the Public Sphere in the age of the French Revolution, Ithaca and London, Cornell University Press, 1988 , pp. 1, 46-49.
} 
uniram conscientemente para alijar as mulheres de seu meio ${ }^{29}$. A conclusão da autora é pessimista: “ [nesta obra] procuro estabelecer que a República foi construída contra as mulheres, não apenas sem elas” ${ }^{30}$ (grifo meu). Comecei minha pesquisa com o tema da repressão das mulheres e a pergunta que orientou grande parte do meu estudo foi o porquê da exclusão. Entretanto, considero a conclusão recém citada radical demais. Para que os homens construíssem um regime contra as mulheres, era necessário que elas estivessem no centro de suas preocupações. Não estavam. Em 1789, a Assembléia Nacional se ocupava com a reforma política, a nova constituição, os problemas de abastecimento, os múltiplos interesses das ordens sociais. E a partir da primavera de 1792, os deputados Girondinos, que até então manifestavam simpatia pelos direitos civis das mulheres, enfrentavam questões mais urgentes: uma monarquia traiçoeira, a séria escassez de trigo , uma guerra externa desastrosa, a revolta colonial, a igreja recalcitrante e a instabilidade da moeda. ${ }^{31}$. Decididamente, a questão dos direitos femininos não era prioritária. Além disso, a suposição de que houve um plano deliberado para excluir as mulheres não se sustenta: em diversas crises políticas, até 1793, as mulheres foram aliadas úteis e valorizadas, por exemplo, ajudaram os Montanheses na expulsão dos Girondinos da Convenção, em maio-junho de 1792. Em geral, contaram com o apoio masculino nas práticas de cidadania, nas jornadas revolucionárias, nos clubes políticos mistos, nas questões de direito de família. Penso que a exclusão ocorreu quando as ativistas se tornaram adversárias políticas dos jacobinos no poder, no outono de 1793, ou turbulentas demais no contexto do movimento de massa popular, em 1795. O importante é perceber que a ruptura revolucionária abalou a ordem estabelecida e criou espaços inéditos para mudanças radicais, inclusive a atuação e a expressão femininas. Nada estava decidido de antemão, tudo era teoricamente possível. Em seu livro sobre o espírito revolucionário dos jacobinos, Patrice Higonnet entende que: « (...) os Jacobinos começavam a compreender mais precisamente (...) que a soberania se situava numa nação-estado unida, fraternal, e recém-moralizada, cujo objetivo era dar poder a cada cidadão individual e talvez a cada

\footnotetext{
29 idem, p. 204.

${ }^{30}$ idem p. 12.

31 KATES, Gary, “ The Powers of Husband and Wife must be Equal and Separate' : The Cercle social and the Rights of women, 1790-1791”. IN APPLEWHITE, Harriet B. \& LEVY Darline G. (edited by) Women \& Politics in the Age of the Democratic Revolution, Ann Arbor, The University of Michigan Press, 1993, Vam
} 
cidadã também” ${ }^{32}$. (grifo meu). Geneviève Fraisse também discorda de Joan Landes quanto à idéia de uma exclusão planejada:

A democracia [da Revolução] é exclusiva , e não excludente, porque não enuncia as regras da exclusão. Ela produz a exclusão por uma série de impedimentos reais e imaginários, jurídicos e médicos. Teria sido necessário que houvesse uma intenção deliberada, um sistema explícito.

Ora, isso não existiu (...)

Foi graças a essa incerteza de enunciado que a inclusão se tornou possível e as mulheres se integraram à República. ${ }^{33}$. De fato, na Declaração dos Direitos do Homem há uma suposição de inclusão de todos os indivíduos, e na legislação revolucionária, exceto no breve período em que houve sufrágio masculino universal, as mulheres foram excluídas do direito de voto junto com os homens que não alcançavam a renda exigida pelo sistema censitário. Nas instâncias políticas cotidianas, sempre que não havia proibição explícita, as mulheres iam ocupando os interstícios da indefinição, freqüentando as galerias das assembléias ao lado dos homens, fiscalizando o cumprimento das leis nos mercados, armando-se quando acharam necessário.

Continuando a discussão da idéia de Joan Landes, de que a " A República foi construída contra as mulheres, e não apenas sem elas" , devo mencionar o as considerações de Lynn Hunt ${ }^{34}$. Esta historiadora considera Women and the Public Sphere in the Age of the French Revolution a obra mais importante sobre a problemática das mulheres na esfera pública e privada, abrindo um caminho que dominou os estudos ingleses e norte-americanos sobre mulheres e Revolução durante toda a década de 1990. Mesmo aqueles que questionaram as teses de Joan Landes , como ela própria, Lynn Hunt, a seguiram na temática escolhida, ou seja, as razões da recusa dos direitos cívicos às mulheres. A historiadora argumenta, entretanto, que essa linha de raciocínio desemboca sempre na desqualificação dos jacobinos e da Revolução Francesa, devido à negação daqueles direitos. E como os líderes

\footnotetext{
${ }^{32}$ HIGONNET, Patrice, Goodness beyond Virtue, Cambridge, Massachusetts e London, England, Harvard University Press, 1998, p. 20.

33 FRAISSE, Geneviève, Les deux gouvernements: la famille et la Cité - Gallimard, 2000, pp.62-63.

${ }^{34}$ HUNT, Lynn, «L'histoire des femmes : accomplissements et ouvertures » IN LAPIED, Martine e PEYRARD Christine (direction) Préface VOVELLE, Michel, La Révolution Française au Carrefour des Recherches , Aix-en Provence, Publications de l’Université de Provence, 2003, citações de Hunt em todo o artigo e principalmente pp. 285-286
} 
revolucionários se inspiraram, quanto à questão do lugar da mulher na sociedade, no pensamento anti-feminista dos filósofos iluministas, principalmente Rousseau, tanto a Revolução como o Iluminismo foram parar "na mesma lixeira da História". Outras autoras endossaram essa visão: Dorinda Outram, numa linha furetiana, concluiu que a Revolução, apagando a distinção entre o Estado e sociedade civil, estabeleceu a condição prévia para os regimes fascistas do século XX. . Madelyn Gutwirth e Margareth George, assim como a francesa Catherine Marand-Fouquet consideram a Revolução uma derrota histórica para as mulheres. Lynn Hunt, alarmada com os ataques concertados de foucaultianos e feministas ao Iluminismo e à Revolução, pelo menos nos países anglófonos, brada sua recusa ao que ela chamou de "discurso do fechamento ", em favor do "discurso da abertura": " (...) sou pela Revolução e pelas Luzes (...) o ataque dirigido[contra a Revolução e as Luzes] exige uma resposta" ${ }^{35}$. E aponta vários estudos que vêem a Revolução não como o fim das esperanças femininas, mas sim como uma época de experimentações criativas, mudanças audaciosas que deixaram legado positivo para as gerações seguintes. Nessa linha, Hunt destaca a obra de Dominique Godineau, Les Citoyennes Tricoteuses - Les femmes du peuple à Paris pendant la Révolution Française (As cidadãs tricoteiras - as mulheres do povo em Paris durante a Revolução Francesa), segundo ela o trabalho mais importante sobre as mulheres na Revolução. A abordagem de Godineau consiste no estudo das práticas políticas das mulheres do povo, seu engajamento na Revolução, e análise das relações masculino-femininas dentro do movimento revolucionário. Sem negar o fato inescapável da exclusão do sexo feminino dos direitos de cidadania, a autora mostra como as cidadãs afirmam seu pertencimento ao Soberano através da ação, criando um espaço próprio que se contrapõe, rejeita ou completa o espaço doméstico. Para ela, o espaço político estava em plena construção e o fato de ser ou não cidadão não dependia inteiramente das definições estipuladas na Assembléia $^{36}$. O discurso de Godineau é portanto o de abertura, e não o do declínio ou fechamento, segundo o conceito de Lynn Hunt.

\footnotetext{
35 idem, p. 286.

${ }^{36}$ GODINEAU, Dominique, « Histoire sociale, histoire culturelle, histoire politique : la question du droit de cité des femmes » IN LAPIED, Martine e PEYRARD Christine (direction) Préface VOVELLE, Michel , La Révolution Française au Carrefour des Recherches, Aix-en Provence, Publications de l’Université de Provence, 2003, pp. 296-297 e Citoyennes tricoteuses, pp. 13-15.
} 
Esta dissertação se desenvolverá sob a égide do discurso de abertura para analisar as práticas femininas, a tensão ou sobreposição entre maternidade e militância e os sistemas culturais de representação, além de refletir sobre a visão e o discurso dos revolucionários em relação a essas questões. Sigo a abordagem de Godineau, que não vitimiza as mulheres, ao contrário, apresenta-as como protagonistas conscientes de seu papel político. Entretanto, não acho possível abandonar a pergunta clássica sobre as razões da repressão ao direito de cidade das mulheres. Penso que na França revolucionária, as ações femininas sempre geraram reações masculinas e vice-versa, pois homens e mulheres lutaram juntos no movimento popular até 1795. A esse respeito, há um artigo relevante de Godineau: " Masculine and Feminine Political Practice during the French Revolution, 1793 - Year III"37 (Práticas políticas masculinas e femininas durante a Revolução Francesa, 1793 - ano III). Por conseguinte, a pergunta se impõe: o que fizeram aquelas militantes para motivar seu alijamento da esfera política? É preciso compreender o contexto social, político e cultural que levou à negação da cidadania feminina, unindo a história de gênero à história da Revolução.

Os artigos de Elisabeth Guibert-Sledziewski também seguem a linha da abertura, denunciando os "fantasmas de esquerda": as mulheres não ganharam nada com a Revolução, e "fantasmas de direita": tudo teria sido melhor sem a Revolução. A autora salienta que:

Pela primeira vez em nossa história, mulheres defenderam causas de mulheres, e homens colocaram a emancipação feminina na ordem do dia (...) a Revolução instalou no terreno da prática política - na rua, nos clubes, nas assembléias - um debate que até então tinha sido teórico e reservado aos salões ${ }^{38}$.

Elisabeth Guibert-Sledziewski repudia o julgamento da Revolução com "espírito de 1815" no seu bicentenário em 1989: "é no capítulo relativo às mulheres que a Revolução é acusada com mais má fé, por ter destruído a família (aprovou o divórcio) e

${ }^{37}$ GODINEAU, Dominique, " Masculine and Feminine Political Practice during the French Revolution, 1793 - Year III" IN APPLEWHITE, Harriet B. \& LEVY Darline G. (edited by) Women \& Politics in the Age of the Democratic Revolution, Ann Arbor, The University of Michigan Press, 1993. pp.61-80.

${ }^{38}$ GUIBERT-SLEDZIEWSKI, Elizabeth, "Une idée neuve de la femme" - postface IN ROSA, Annette, Citoyennes, Paris, Messidor, 1988, p. 239. 
por ter sido machista (excluiu as mulheres dos direitos políticos)" ${ }^{39}$. Dessa forma, contrabalança a exclusão cívica das mulheres com a conquista de direitos civis, ou seja, com o advento civil de uma mulher livre em seus sentimentos e escolhas, dona de uma personalidade civil moderna ${ }^{40}$. A autora faz uma reflexão sobre o estatuto jurídico da mulher: ela é sujeito para realizar os direitos reconhecidos a todo indivíduo membro da sociedade, mas não para participar da elaboração das leis que regem esses direitos. Nesse sentido, ela é objeto, e não sujeito da legislação - mesmo assim, "O direito privado da Revolução é parcial mas intensamente liberador, promotor de uma nova forma de individualidade civil, testada primeiro pela mulher".

Acho a argumentação pertinente e bem fundamentada, além de colocar em evidência outros foros onde a mulher pode exercer a defesa de seus direitos, no caso, os tribunais civis. Suzanne Desan também se debruçou sobre direito de família, em artigos como "War between Brothers and Sisters: Inheritance law and Gender Politics in Revolutionary France" ${ }^{41}$ (Guerra entre irmãos e irmãs: lei de heranças e política de gênero na França Revolucionária) onde assinala que o ambiente politizado da Revolução impulsionou a luta pelos direitos da mulher dentro da família, criando espaços para mudanças legais e ativismo político.

Olwen H. Hufton fez um estudo instigante das práticas políticas femininas, não só das militantes revolucionárias, como também das contra-revolucionárias e religiosas obrigadas a sair de seus conventos, em Women and the Limits of Citizenship in the French Revolution (1992). Para essa autora, a principal razão para o fechamento dos clubes políticos de mulheres em outubro de 1793 não foi o anti-feminismo dos jacobinos e sim um modo de reduzir as ameaças à ordem pública geradas pelos distúrbios entre grupos de mulheres no mercado ${ }^{42}$. Outrossim, Hufton salienta que, no

\footnotetext{
${ }^{39}$ GUIBERT-SLEDZIEWSKI, Elizabeth , "La femme, objet de la Révolution », Síntese de duas comunicações feitas na Assembléia da Société des Études Robespierristes, em junho 1984, e no Collège International de Philosophie, seminário Formes du féminisme historique, G. Fraisse, em abril de 1986, p. 4 e citação, p. 5.

${ }^{40}$ GUIBERT-SLEDZIEWSKI, Elizabeth, "Une idée neuve de la femme" op. cit. p. 246.

${ }^{41}$ DESAN, Suzanne - "War between Brothers and Sisters: Inheritance law and Gender Politics in Revolutionary France", French Historical Studies, vol. 20 (Autumn, 1997), pp. 597-634, Duke University Press,p. 634.

42 HUFTON, Olwen H., Women and the Limits of Citizenship in the French Revolution, Toronto, Buffalo, London, University of Toronto Press, 1992, pp.36-38.
} 
entender dos políticos, haveria ligação entre os Enragés e as militantes de Paris - tal argumento foi utilizado por Margaret George em seu artigo sobre a derrota das Cidadãs Republicanas Revolucionárias ${ }^{43}$. Penso que a ligação entre essas ativistas e os Enragés não foi decisiva na proibição dos clubes, apesar dos laços pessoais entre Leclerc e Pauline Léon e Claire Lacombe, fundadoras e sucessivamente presidentes da Sociedade das Republicanas Revolucionárias. Essa visão diminui a independência e a importância do grupo, relegando-o quase à condição de braço feminino dos Enragés. Já o estudo de Hufton sobre as contra-revolucionárias me pareceu muito importante por revelar um ativismo feminino que de forma alguma se limitava a ocultar clérigos refratários e organizar missas clandestinas. Ao contrário, o boicote ativo e o desafio à autoridade dos representantes em missão, juntamente com a resistência passiva à descristianização no seio da família deram origem ao temor republicano do triunfo do clericalismo através das mulheres. Nesse sentido, as contra-revolucionárias tiveram mais influência que as ativistas republicanas na recusa duradoura de direitos políticos a todas as francesas no século XIX, como proposto por Michelet. Embora esse grupo não faça parte do meu estudo, foi útil perceber os mecanismos que geraram o fantasma da aliança entre a mulher e a igreja como responsável pelo fracasso do primeiro republicanismo ${ }^{44}$.

Women \& Politics in the Age of the Democratic Revolution é uma obra coletiva que reúne, entre outros, trabalhos sobre o papel das mulheres nas revoluções democráticas da Holanda, Bélgica, Estados Unidos da América e França. Embora todas elas houvessem inspirado seus homens à ação, e defendido os interesses de suas comunidades locais, só as francesas ultrapassaram os limites de seus bairros para interagir com líderes de instituições políticas nacionais e reivindicaram uma identidade política como cidadãs e membros da nação soberana ${ }^{45}$. No capítulo escrito pelas editoras do livro, Harriet B. Applewhite e Darline G. Levy, há uma análise sobre as

\footnotetext{
${ }^{43}$ GEORGE, Margareth, "The World Historical Defeat" of the Républicaines -Révolutionnaires" IN Science \& Society, no. 40.4 (Winter 1976-1977), pp. 410-437.

${ }^{44}$ HUFTON, Olwen H., Women and the Limits of Citizenship in the French Revolution, Toronto, Buffalo, London, University of Toronto Press, 1992, pp. 138-145.

${ }^{45}$ APPLEWhiTe, Harriet B. \& LEVY Darline G. (edited by) Women \& Politics in the Age of the Democratic Revolution, Ann Arbor, The University of Michigan Press, 1993., p. 14, e capítulo de Godineau na mesma obra, p. 78.
} 
jornadas de 9 de abril e 20 de junho de 1792. Nessas duas ocasiões, soldados, Guardas Nacionais, mulheres, crianças, cidadãos, todos armados, se fizeram representar como uma nova força simbólica, política e militar, como uma família nacional em armas que não poderia ser vencida. A imagem da família republicana unida é poderosa e ajuda a compreender como, naquele meio e circunstância, começou a se forjar o conceito de cidadania feminina. Os capítulos acima mencionados provocam uma reflexão sobre as razões da singularidade política das francesas, as quais se integraram plenamente no movimento revolucionário, ao contrário de contemporâneas em outros países que tiveram atuação mais modesta e limitada.

\section{La femme au temps de la Révolution (A mulher no tempo da Revolução) de} Catherine Marand-Fouquet é um livro abrangente, que relata os principais acontecimentos revolucionários (1789-1799), do ponto de vista feminino. Apresenta uma galeria de mulheres de todas as condições sociais e profissões assinalando como participaram ou foram afetadas, em geral negativamente, pela Revolução. A autora se refere aos crimes hediondos e à barbárie que as mulheres sofreram no período revolucionário na guerra da Vendéia, mas também nas prisões, guilhotinadas depois dos maridos, como Lucille Desmoulins e Françoise Hébert.

A conclusão é sombria: para as mulheres, a Revolução foi uma oportunidade perdida. A burguesia triunfante conseguiu impor seus modelos de comportamento aos gêneros, preparando o caminho para o Código Civil de 1804, que colocou a mulher em estado de subordinação e menoridade vitalícias. Marand-Fouquet não acredita que as ações femininas ou feministas tenham deixado as sementes de uma emancipação futura: "entre elas e as feministas contemporâneas, nenhuma continuidade. Se alguma coisa germinou, nesse meio tempo, foi a condição infeliz, social e política da francesa, consagrada no código civil alguns anos mais tarde". ${ }^{46}$ Outros países europeus foram mais generosos com as mulheres, em parte porque tiveram grandes Rainhas, como Elizabeth da Inglaterra, Cristina da Suécia e Maria Teresa da Áustria, que predispuseram seus cidadãos a aceitarem um governo de mulheres. A autora não acredita que a Revolução Francesa pudesse ter realizado a emancipação feminina.

\footnotetext{
${ }^{46}$ MARAND-FOUQUET, Catherine, La femme au temps de La Révolution - 1989, Éditions Stock/Laurence Pernoud.p. 376 - para esta conclusão, ver capítulo "Le rendez-vous manqué'.
} 
Outra obra panorâmica e fartamente ilustrada é Citoyennes (Cidadãs) de Annette Rosa, que oferece uma visão geral da questão feminina durante a Revolução, numa linha de "discurso de abertura". Embora não tenha formato acadêmico - faltam as notas de rodapé - o texto é de uma especialista na matéria, e endossado por E. Guibert-Sledziewski e Claude Mazauric. No capítulo "Pérfido Rousseau?" , em vez de enfatizar os aspectos negativos do pensamento rousseauísta em relação à mulher, a autora procura compreender a espantosa popularidade do filósofo entre as mulheres do fim do século XVIII. Como era a vida conjugal das mulheres naquela época? Na sociedade aristocrática do século, as mulheres não podiam esperar nenhuma felicidade em seus casamentos arranjados. O cinismo tinha chegado ao seu ápice, o carinho entre esposos era o último dos ridículos, o amor conjugal uma infelicidade da plebe , um sentimento que comprometia a reputação de um homem ou mulher "do mundo". Diderot preconizou outro padrão moral para o casamento, baseado no respeito mútuo e fidelidade, como explicou em carta de 1772 à sua filha recém-casada ${ }^{47}$. Este documento está incluído no item "Anexos" desta dissertação. Rousseau condenou a infidelidade de ambos os cônjuges, e declarou que o marido que trai era injusto e bárbaro. E foi além: defendeu o direito da mulher ao casamento por amor, em nome da "ordem dos sentimentos naturais", e ordenou aos jovens que se amassem, autorizando a coincidência entre o prazer e a virtude. Exaltou a maternidade : "que as mães amamentem suas crianças, e os costumes se reformarão sozinhos (...) os homens voltarão a ser pais e maridos. O Estado se repovoará" ${ }^{48}$. A mãe estava no centro da família, tinha o amor do marido e dos filhos, era valorizada e respeitada pela sociedade - essa idéia era nova e encontrou enorme aceitação entre as mulheres. Lynn Hunt pensa o mesmo que Annete Rosa em relação ao anti-feminismo dos filósofos do XVIII, dizendo que eles foram homens de sua época, e compartilharam dos preconceitos dos seus contemporâneos europeus sobre judeus, africanos e mulheres. Hunt contextualiza aquelas idéias, que de outra forma nos parecem chocantes, e enfatiza a novidade da exaltação da mulher na maternidade ${ }^{49}$. Penso que, se o culto à

\footnotetext{
${ }^{47}$ DIDEROT, Denis, Lettre à Madame Caroillon - 13 de setembro de 1772, Corespondance vol. 5 IN LUCAS, Colin, Editor-in-Chief The French Revolution Research Collection, University of Chicago, 1992, The New York Public Library - A carta está no Anexo B desta Dissertação.

${ }^{48}$ ROSA, Annette, Citoyennes, Paris, Messidor, 1988 , pp. 52-55.

${ }^{49}$ HUNT, Lynn, «L'histoire des femmes : accomplissements et ouvertures » IN LAPIED, Martine e PEYRARD Christine (direction) Préface VOVELLE, Michel, La Révolution Française au Carrefour des Recherches, Aix-en Provence, Publications de l’Université de Provence, 2003, p. 286.
} 
maternidade foi em certa medida uma compensação à mulher pelo seu afastamento da vida pública, por outro lado ofereceu um caminho para a integração feminina à nova ordem social republicana.

Os trabalhos de Lynn Hunt foram subsídios essenciais para o desenvolvimento do tema desta dissertação. A obra The Family Romance of the French Revolution ${ }^{50}$ (O Romance da Família na Revolução Francesa) oferece uma abordagem psicanalítica de origem freudiana para a ruptura revolucionária. Nesta reflexão, os franceses teriam tido o desejo de se livrar de seus pais políticos a quem menosprezavam - o Rei e a Rainha - e substituí-los por uma família sem pais, na qual os filhos, principalmente os irmãos, agissem com autonomia. Essa fraternidade não saberia bem o que fazer com as irmãs, as quais foram afastadas da esfera política essencialmente masculina. Sinto certo desconforto com a psicanálise aplicada aos estudos históricos: parece-me que os conflitos de situações individuais são dificilmente transpostos para toda uma sociedade, e às vezes as analogias ficam um tanto "forçadas". Feita esta ressalva, a obra contém interpretações esclarecedoras sobre a iconografia revolucionária, e é valiosa para explicar a questão da militância e da maternidade cívica, das reações masculinas às ativistas, e finalmente da evolução do direito de família. Outro livro da autora, Política , Cultura e Classe na Revolução Francesa ${ }^{51}$ é especialmente importante devido à abordagem de temas como a interação entre política , cultura e simbologia da prática política. Nessa mesma linhagem interpretativa, saliento a importância de mais dois artigos de Hunt: "Engraving the Republic - Prints and Propaganda in the French Revolution"52 (Registrando (ou gravando) a República - gravuras impressas e propaganda na Revolução Francesa) e "Hercules and the Radical Image in the French Revolution" (Hércules e a Imagem Radical na Revolução Francesa). Nesses trabalhos, Hunt analisa a criação dos símbolos republicanos, a crise de representação da soberania que emergiu com a morte do Rei, e

\footnotetext{
${ }^{50}$ HUNT, Lynn, The Family Romance of the French Revolution, University of California Press, 1992, prefácio.

${ }^{51}$ HUNT, Lynn, Política, Cultura e Classe na Revolução Francesa, (trad.) São Paulo, Cia. Das Letras, 2007 .

${ }^{52}$ HUNT, Lynn, "Engraving the Republic: Prints and Propaganda in the French Revolution” History Today, no. 30 (October 1980).

HUNT, Lynn. "Hercules and the Radical Image in the French Revolution", Representations, no. 2 (Spring, 1983) pp. 95-117 - JSTOR.
} 
as relações complexas do jogo de poder entre os deputados e o povo. Essas tensões se refletem na escolha das figuras femininas, masculinas, ou abstratas, nas diferentes fases da Revolução.

Para concluir este diálogo com a historiografia, reconheço que a minha visão da questão feminina se refinou ao longo da pesquisa. No início alinhei-me às idéias de Joan Landes sobre a repressão política das mulheres na Revolução. Havia um consenso em torno do "discurso de fechamento" entre os historiadores que escreveram na década de 1990, alguns dos quais citei acima. Não se trata agora de negar a repressão, mesmo porque isso seria impossível, se considerarmos que houve as leis de 1793 e 1795 , e mais tarde o Código Napoleônico de 1804 que consagraram em lei a limitação dos direitos femininos. Mesmo os historiadores do "discurso de abertura" reconhecem a repressão, porém tendem a estabelecer nuances, graus e ressalvas nesse processo. Diante da nova perspectiva historiográfica (anos 2000) e das evidências que encontrei na documentação escrita por homens e mulheres, redirecionei o enfoque anterior que apenas tratava da repressão - para incluir a experiência política feminina, a qual foi pioneira e singular, por isso suscitou tantas controvérsias. Como resultado da nova perspectiva, a reflexão se voltará para a relação entre os discursos femininos e masculinos, levando em conta que as visões de gênero não são unívocas. Por discurso, entendo práticas políticas, decisões legislativas, e representação simbólica republicana. 
CAPÍTULO 1

O ativismo das mulheres no espaço público 
1.0 - Preâmbulo

O objetivo deste capítulo é discutir, em primeiro lugar, as aspirações femininas em 1789 a partir das cartas e panfletos reunidos nos Cahiers de Doléances (Cadernos de Queixas). Essas cartas, assinadas ou anônimas, foram endereçadas ao Rei Luís XVI ou aos deputados dos Estados Gerais e expressavam queixas e aspirações de uma ou mais mulheres de diferentes condições sociais e níveis de educação. Em seguida, passarei ao tema dos direitos civis e políticos das mulheres durante a Revolução Francesa pelo viés das práticas políticas femininas, principalmente das militantes das classes populares. O discurso de outras mulheres pode ser mencionado na medida em que servem de contraponto às idéias e ações das ativistas. A discussão focalizará a atuação de três grupos de mulheres: as mães, as militantes e as mulheres-soldados, e a repercussão de suas ações na sociedade, segundo a documentação e bibliografia consultada. As reflexões do capítulo giram em torno de alguns acontecimentos emblemáticos nos quais houve participação marcante das mulheres ou práticas femininas relevantes na história da Revolução e na história do movimento feminino organizado.

\section{1 - As aspirações das mulheres: Os Cahiers de Doléances}

No clima de efervescência da convocação dos Estados Gerais em agosto de 1788 (para início em maio de 1789), Luís XVI convidou todos os franceses a lhe transmitirem seus Cahiers de Doléances, pensando que só a nobreza, o clero e a alta burguesia se expressariam, e com moderação. Mas a crescente insatisfação e a vontade de mudança foram de tal ordem que a redação dos documentos ensejou um grande debate público, como atestam os 60.000 cadernos que chegaram até nós ${ }^{53}$. As mulheres, no entanto, não foram consultadas nesse grande testemunho coletivo, exceto as que eram membros de algumas guildas, como as floristas e modistas de Paris. Mesmo assim, algumas resolveram se manifestar escrevendo - e publicando - suas

\footnotetext{
${ }^{53}$ CARBONNIER, Annelise, TOULET, Michel, LECAT, Jean-Michel, La longue marche des femmes - 1789-1920 - des citoyennes aux suffragistes - Paris, Ed. Phébus, 2008 p. 34-35.
} 
queixas em cartas, petições, e brochuras dirigidas ao Rei e aos Estados Gerais. O espírito das Luzes permeava esses escritos: a maioria pede mais educação, mais esclarecimento, e até oportunidade de trabalho, além de demonstrar aguda percepção da situação política. E quase todas as cartas se referem à necessidade de moral e bons costumes (moeurs) para reformar a sociedade. Apresentarei a seguir seis cartas que tratam dos temas mais comumente encontrados.

A autora anônima do panfleto Do Destino Atual das mulheres, aos bons Espíritos ${ }^{54}$, posterior aos Estados Gerais, demonstra uma consciência feminista avantla-lettre: está indignada com exclusão das mulheres pela nova Constituição e com a interpretação excludente que certos legisladores faziam da Declaração dos direitos do Homem e do Cidadão : "a metade da espécie humana está privada de seus direitos naturais; e definha num estado que se aproxima da escravidão(...)" Protesta veementemente contra o artigo 29 da nova lei penal, que equipara as mulheres aos homens estrangeiros para efeitos das sentenças judiciárias, como se a pátria as rejeitasse, apesar de: “amarem a pátria com uma ternura incomparável, porque aqueles que a compõem nascem de suas dores" 55 . "Como ousam! eles [os legisladores] ao redigir as leis, assimilaram sem pudor as suas companheiras, mães e filhas aos homens estrangeiros!"

Indignada com a injustiça, a autora pondera que se uma parte dos erros do governo é atribuída a uma "mulher estrangeira" (Maria Antonieta), seria justo manifestar que o povo francês é estimável igualmente em seus dois sexos. Para ela, a culpa e o mérito têm que ser igualmente atribuídos. A missivista faz anotações para si própria: "bom para meus filhos e filhas. O estudo por meia-hora que seja (...)" Diz que a força moral é um dom que a natureza concede à mulher, e fala da importância dos bons costumes (moeurs) para as mulheres serem respeitadas. Para isso, é preciso devolver-lhes suas propriedades e seus direitos, tão sagrados quanto os dos homens. Essa autora não vê nenhuma razão lógica ou justa para um tratamento desigual e discriminatório em relação à mulher francesa. Ela considera que as mulheres amam a pátria e fazem parte da nação, e devem ter os mesmos direitos que os homens.

\footnotetext{
${ }^{54}$ Cahiers de doléances des femmes en 1789 et autres textes - préfacé par Paule-Marie Duhet Paris, C. Des femmes 1981 , p. 115.

${ }_{55}$ Cahiers de doléances des femmes en 1789 et autres textes - préfacé par Paule-Marie Duhet Paris, C. Des femmes 1981 p. 113.
} 
Outra carta notável é a Petição das mulheres do Terceiro Estado ao Rei , de 1 de janeiro de $1789^{56}$. A autora anônima queixa-se da educação deficiente dada às meninas, e das escolhas infelizes que as mulheres têm na vida: o casamento sem amor, o claustro, o serviço doméstico, o celibato desprezado ou a libertinagem. Seu principal pedido ao rei é de uma modernidade surpreendente: ela quer uma educação que permita às mulheres oportunidades de trabalho e vida independente. Além disso, acha que certas profissões devem ser reservadas para as mulheres - os homens ficariam proibidos de exercê-las:

que nos deixem pelo menos a agulha e o fuso, nós nos comprometemos a jamais tocar no esquadro e compasso"; Educar-se para trabalhar: "nós desejamos ser esclarecidas (.. )para que tenhamos os meios de viver ao abrigo do infortúnio" "(...) sair da ignorância para dar aos nossos filhos uma educação sã e razoável (...) nós vos suplicamos, Majestade, que estabeleçais escolas gratuitas.

Mais uma vez lemos pedidos de educação e trabalho. Por um lado essa carta é de uma notável modernidade, defendendo a independência de vida para mulheres através da autonomia financeira, educação como responsabilidade do Estado, mas tradicional no tocante à separação das profissões adequadas para mulheres e homens. E a ironia em relação às atividades científicas, ciosamente reservadas para os homens, acrescenta uma provocação apimentada ao texto.

A carta de Madame $\mathbf{B}^{* * *} \mathbf{B}^{* * * 57}$ expressa surpresa com o silêncio das mulheres no momento da "revolução geral" em curso, pois haveria tantos abusos a combater, queixas a apresentar. A autora ousa elevar a voz para defender uma causa comum. Com agudeza de espírito, percebe que debate-se a libertação dos negros - será que a filosofia ficaria muda a respeito das mulheres? O lema das mulheres parece ser "trabalhar, obedecer e se calar". Madame B *B exige a cidadania para as mulheres: considera que elas não estão representadas nos Estados Gerais, pela mesma razão que um nobre não pode representar um comerciante. A educação feminina não se resume a aprender a agradar, mas sim ser útil à família e à sociedade, é preciso mudar as regras

\footnotetext{
${ }^{56}$ Cahiers de doléances des femmes en 1789 et autres textes - préfacé par Paule-Marie Duhet Paris, C. Des femmes 1981, p. 25

${ }^{57}$ Les Tracts féministes au XVIIIe siècle - publiés avec une introduction par Colette Michael, Editions Slatkine, Genève - Paris, 1986 - Bibliothèque de la Sorbonne, p. 121-128
} 
da educação. A autora acha que as mulheres não podem ser privadas dos conhecimentos que a tornam capaz de ajudar os homens. Há um grande desejo de aperfeiçoamento, e de repúdio aos antigos costumes que só enchiam de frivolidades as cabeças das mulheres. ${ }^{58}$ Dessa forma, as pessoas de bom senso reconhecerão que agora as mães de família razoáveis se ocuparão frutiferamente de seus afazeres domésticos e discutir os interesses públicos com conhecimento e discernimento. Madame B quer uma uniformização das leis em todas as províncias do país, segundo critérios ditados pela razão, sabedoria e justiça. A autora se insurge contra o costume da primogenitura, pela sua flagrante injustiça com outros irmãos e irmãs. E dá sugestões em política econômica: para sanar a dívida nacional, recomenda o confisco dos bens das ordens religiosas adquiridos por vias escusas, que por essa razão seriam ilegítimos.

Outra reivindicação feminina expressa nos Cahiers de Doléances e em outros documentos da época, era o direito ao divórcio. Em Agravos e Queixas das mulheres mal-casadas ${ }^{59}$, dirigido à Assembléia Nacional, a autora anônima lança mão de argumentos ousados contra a indissolubilidade do casamento. A reação negativa dos religiosos podia ser antecipada, nesta pergunta retórica: “(...) vocês ignoram que o que nós ligamos na terra está ligado no céu? Jesus Cristo o disse. Eis nossa resposta: um laço formado contra as intenções da natureza não foi ligado no céu". É interessante notar como os princípios revolucionários permeavam todas as questões, inclusive a do casamento e do divórcio. Como tudo mais, a indissolubilidade do casamento foi politizada, e pensada à luz da Liberdade: um princípio maior e um direito fundamental dos homens, pouco tempo depois consagrado na Declaração dos

\section{Direitos do Homem e do Cidadão.}

Um voto indissolúvel é um atentado à liberdade do homem e o sistema atual é e deve ser aquele da Liberdade" "A França rompeu suas cadeias, a Liberdade torna-se (...) a base de todas as nossas leis (...) então porque esses grilhões, cadeados, este cativeiro perpétuo, dignos do despotismo oriental?"60 A Razão iluminista entra na liça:"a indissolubilidade de um voto o torna desarrazoado e absolutamente contra a natureza(...)

\footnotetext{
58 idem, p. 124.

${ }^{59}$ Cahiers de doléances des femmes en 1789 et autres textes - préfacé par Paule-Marie Duhet Paris, C. Des femmes 1981 , pp. 143 e 147.

${ }^{60}$ idem, p. 148.
} 
Além de educação e direitos de cidadania, as mulheres queriam proteção econômica. À época da Revolução, as mulheres integravam a força de trabalho, nos mais diversos setores: prataria, encadernação, papelaria, comércio de alimentação, costura, pequenas atividades de rua. Seus salários eram sempre inferiores aos dos homens pelas mesmas tarefas, e uma doença ou um acidente podia privá-las de recursos $^{61}$. Algumas guildas exclusivamente femininas sobreviveram de facto à abolição oficial por Turgot (editos de 1776-1777) e seus membros pediram proteção aos Estados Gerais, ou ao Diretor Geral de Finanças, como fizeram as vendedoras de flores $^{62}$ nos Cahiers de Doléances des Bouquetières (Cadernos de Queixas das Floristas). As floristas queriam o restabelecimento de seus direitos, visto que “(...) elas pagaram ao rei somas consideráveis para usufruir das vantagens de sua profissão, vantagens das quais são privadas pela grande concorrência e as desordens que ela acarreta (...)”.

Havia também um aspecto moral na reclamação: as “irregulares” são incompetentes, não conseguem sobreviver do que ganham, e descambam para a vida libertina: "elas procuram na libertinagem e na mais desavergonhada devassidão os recursos que lhes faltam. A causa das peticionarias é a dos bons costumes." (grifo meu). Neste caso, assim como no das outras cartas em nome de corporações de ofício, as mulheres pedem proteção contra concorrentes desleais e libertinas. E o fazem em nome da moral e dos bons costumes: essa é a grande novidade desse tipo de carta, que no mais, segue a tradição da reserva de mercado para os membros das guildas. Além disso , as comerciantes se aventuram numa definição de liberdade que as favorece, contagiadas pela necessidade de falar a linguagem política que encontra ressonância nos Estados Gerais e outras instâncias do poder: "A Liberdade, defendida por todas as Ordens de Estado, não pode ser obstáculo à demanda das peticionárias. A Liberdade é inimiga do desregramento , e os cidadãos serão livres sempre que obedecerem às leis que eles próprios se impuseram"63.

\footnotetext{
${ }^{61}$ MARAND-FOUQUET, Catherine, La femme au temps de La Révolution - 1989, Éditions Stock/Laurence Pernoud, pp. 26-27.

${ }^{62}$ Cahiers de doléances des femmes en 1789 et autres textes - préfacé par Paule-Marie Duhet Paris, C. Des femmes 1981, Cahier de Doléances des bouquetières - pp. 31-37.

${ }^{63}$ idem, p. 37.
} 
Consoante com o espírito geral, em algumas petições transparece a fé no poder de transformação social das leis e da Constituição. Um exemplo é o documento A Gráfica das mulheres (L'Imprimerie des femmes) ${ }^{64}$, de Mme. de Bastide, a qual propôs a criação de uma escola gratuita de tipografia e liceu para mulheres. Para a autora, a Constituição trará consigo uma nova moral social. $\underline{A}$ tipografia e o liceu seriam fundados sob a égide da regeneração dos costumes, tanto para os homens como para as mulheres: as mulheres se educarão e os homens não mais se permitirão ridicularizá-las.

uma nova Constituição prepara e traz nova moral e novos costumes (...) o ignorante, tolo ou orgulhoso não se permitirá mais, sem dúvida, ridicularizar as mulheres, as quais, pelo estudo e meditação buscarão desenvolver o germe dessas virtudes (...)

regenerar a educação das mães de família, ou das moças destinadas à maternidade (...) lhes proporcionar os meios de adquirir todos os conhecimentos que possam alcançar, e persuadi-las sobretudo que o princípio motor da felicidade é o trabalho e a instrução, e que em todos os lugares e todos os tempos, é sobre a ignorância que a tirania funda seu império (...)

Mme. de Bastide observou que as mulheres tinham qualidades para se tornarem boas tipógrafas: eram naturalmente sedentárias, habilidosas, pacientes e ordenadas no trabalho. Entre as condições para aceitação de candidatas na escola gratuita, a primeira era: "que as mulheres saibam ler e escrever bem e que tenham uma moral inatacável (...)” . A República exigia moral sólida de todos os cidadãos e cidadãs.

Nesta pequena amostra de cartas escritas por mulheres ao Rei e aos Estados Gerais, já se nota a tendência de certas reivindicações que se intensificarão no curso da Revolução: melhor educação para as meninas para que possam ser úteis à sociedade; oportunidade de trabalho; ensino de ofícios às mulheres; direito da mulher à propriedade; repúdio à tradição da primogenitura nas heranças; leis penais equânimes para ambos os sexos. A linguagem da moral e da política permeia os Cahiers de Doléances. As autoras invocam a justiça, a igualdade e a liberdade para defender seus direitos. Mesmo antes, e certamente depois da Bastilha (algumas cartas são posteriores à reunião dos Estados Gerais) percebe-se uma indignação reprimida por parte das mulheres, as quais levantaram suas vozes contra a injustiça de sua condição na família, na sociedade, no trabalho, e perante a legislação. Tinham urgência em se

\footnotetext{
${ }^{64}$ Cahiers de doléances des femmes en 1789 et autres textes - préfacé par Paule-Marie Duhet Paris, C. Des femmes 1981, pp.87-93.
} 
fazer ouvir, e expressaram seu descontentamento com firmeza e altivez. Sua atitude prenuncia a politização e o engajamento feminino na Revolução. As cartas aqui apresentadas são de autoria feminina , de pessoas oriundas da burguesia educada, ou de membros de corporações de ofício. Representam porém, sentimentos compartilhados por mulheres de outras classes sociais, e também homens, que se comprometerão a defendê-los ao longo da Revolução.

\section{2 - A República da Virtude}

Para compreender melhor as práticas femininas na era revolucionária, julguei importante situar as personagens no ambiente da campanha de regeneração moral que permeava a vida política e social no período estudado. Mesmo antes do início da Revolução, instaurou-se na França um discurso de moralização dos costumes considerados corruptos e decadentes da sociedade aristocrática do fim do século XVIII. As artes refletiam o mal-estar social vigente. Choderlos de Laclos tinha denunciado os vícios e a malícia das mulheres poderosas e devassas, no romance epistolar Ligações Perigosas, de 1782. Novos princípios de patriotismo, lealdade e virtude republicanas foram propostos no quadro de Jacques-Louis David, O Juramento dos Horácios, de 1784. Durante a Revolução, os dirigentes franceses se lançaram à empresa de reformar o Estado, acabar com os privilégios, as injustiças, reformar as leis, o calendário, os pesos e medidas, e inspirados nas idéias dos filósofos iluministas como Rousseau e Diderot, promover a regeneração moral da nação.

Tocqueville atribuiu a "ilusão de ruptura e fundamento" revolucionária às teorias políticas abstratas elaboradas pelos escritores do século XVIII. Essas idéias explicariam a vontade e a consciência de uma inovação absoluta que caracterizam a Revolução: " Os franceses fizeram em 1789 o maior esforço jamais empreendido por qualquer povo, para cortar em dois, por assim dizer, o seu destino, e separar por um abismo o que eles tinham sido até então do que queriam ser dali em diante" ${ }^{65}$.

\footnotetext{
65 TOCQUEVILLE, Alexis de, L'Ancien Régime et la Révolution, Paris, Gallimard, 1967, p. 43 IN CHARTIER, Roger, Les origines culturelles de la Révolution française, Paris, Seuil, 2000, pp. 28-29.
} 
De fato, inspirados principalmente em Rousseau, os homens da Revolução se lançaram à tarefa sobre-humana de transformar um desejo em realidade: a reconstituição da inocência adâmica, a criação de um novo homem, enérgico, frugal , dotado de nova sociabilidade moral ${ }^{66}$. Em outras palavras, a República precisava de indivíduos de outra têmpera: queria cidadãos virtuosos, em tudo diferentes dos súditos do Rei. Robespierre definiu o que é a virtude no discurso Sobre os princípios de moral política em que anunciou a vontade de substituir todos os vícios e todos os ridículos da monarquia por todas as virtudes e milagres da República, entre eles:

[queremos substituir] o egoísmo pela moral, a honra pela probidade, as conveniências pelos deveres, a tirania da moda pelo império da razão, o desprezo da infelicidade pelo desprezo ao vício, a insolência pelo orgulho, o amor do dinheiro pelo amor à glória, os usos pelos princípios" " a alma da República é a virtude " "A virtude pública (...) não é outra coisa que o amor à pátria e às suas leis"; o amor à pátria inclui necessariamente o amor à igualdade ${ }^{67}$.

Por outro lado, a definição jacobina de vida pública tornou-se mais masculina, moralizante e aos poucos apagou a fronteira entre a vida privada e a vida pública: "para ser um homem honesto, é preciso ser bom filho, bom marido e bom pai...e reunir todas as virtudes privadas e públicas...eis aí a verdadeira definição de patriotismo", explicou um francês a um cidadão da Filadélfia num panfleto revolucionário ${ }^{68}$. Robespierre e Saint-Just compartilhavam da mesma visão de moral social derivada de Rousseau. Robespierre não se considerava agente, nem defensor do povo: " Eu sou o próprio povo". Saint-Just se apresentava como livre de qualquer mácula de iniquidade, e assim esperava que fossem todos os homens públicos. Estes deviam prestar contas de sua virtude à cidade ${ }^{69}$. O espírito público, a própria essência da virtude jacobina, passou a importar mais que a natureza humana e seu invólucro material. O homem jacobino regenerado e virtuoso podia e devia elevar-se acima de si mesmo. Ele colocava em prática os princípios republicanos na sua vida privada e pública,

\footnotetext{
${ }^{66}$ OZOUF, Mona, L'Homme Régénéré - Essais sur la Révolution Française, Paris, Gallimard, 1989, pp. 118-119.

${ }^{67}$ ROBESPIERRE, Maximilien, "Sur les principes de morale politique" 5 février 1794/17 Pluviôse an II, publicado por ZIZEK, Slavoj IN Robespierre : entre vertu et terreur - Editions Stock, 2008 (traduction française) pp. 224-227.

${ }^{68}$ HIGONNET, Patrice, Goodness beyond Virtue, Cambridge, Massachusetts e London, England, Harvard University Press, 1998, pp. 136- 137.
}

${ }^{69}$ BLUM, Carol, Rousseau and the Republic of Virtue - The language of Politics in the French Revolution, Ithaca and London, Cornell University Press, 1986 , p. 160-163. 
participava entusiasticamente das votações, festas e rituais cívicos, defendia a Revolução dentro e fora das fronteiras, era franco, mantinha promessas, identificava-se com a nação, e acreditava na amizade, no sacrifício pelo bem comum ${ }^{70}$.

\section{3 - A conquista do espaço moral}

Em vista da disseminação de tais doutrinas, nada mais natural que as mulheres tivessem, por sua vez, abraçado aqueles elevados ideais para compartilharem do espírito público da cidadania. Emilie Tardy de Besançon, filha de emigrados, rompeu com a política contra-revolucionária de sua família em 1793 e filiou-se ao clube feminino de Besançon. Mesmo levando-se em conta que ela precisava provar mais enfaticamente que suas irmãs republicanas a sua lealdade à República , sua linguagem de elevação moral é semelhante à das outras participantes:

Cidadãs, irmãs, amigas... Eu me alcei o quanto pude às alturas do espírito nacional; o afeto familiar, os laços de amizade nunca me desviaram, nem desviarão dos princípios de liberdade e igualdade... Peço-vos que aceitem , irmãs e amigas, este testemunho público da minha gratidão.

No mesmo tom, a cidadã Maugras de Besançon declarou: "Elevadas às alturas da Revolução, nós preferimos a liberdade e a igualdade a todas as trivialidades do amor" ${ }^{71}$. Logo depois da aprovação da lei do divórcio em 22 de setembro de 1792, a Mère Duchesne escreveu com otimismo um tanto precipitado:

"antes, quando queríamos falar, calavam-nos dizendo polidamente: "a senhora raciocina como mulher" (...) agora tudo mudou; nós crescemos muito depois da Revolução (...) Meu Deus! Como a liberdade nos deu asas! Hoje nós voamos como as águias"72 ${ }^{72}$.

O entusiasmo dessas mulheres era sincero, apesar de não terem oficialmente nenhuma das prerrogativas da cidadania. A novidade do espírito revolucionário, herdeiro da ilustração, é que ele inflamou os corações. Tocqueville havia percebido como a filosofia política do século XVIII chegou às multidões e se transformou numa

\footnotetext{
${ }^{70}$ HIGONNET, Patrice, Goodness beyond Virtue, Cambridge, Massachusetts e London, England, Harvard University Press, 1998, idem, p. 133.

71 DESAN, Suzanne - “Constitutional Amazons: Jacobin Women’s Clubs in the French Revolution” IN

Re-creating Authority in Revolutionary France, edited by Bryant T. Ragan, Jr.and Elizabeth A. Williams, New Brunswick, New Jersey, Rutgers University Press, 1992 , as 2 citações, p. 26 - 27.
} 
paixão política , de tal modo que: "(...) vimos teorias gerais e abstratas sobre a natureza das sociedades tornarem-se assunto de conversas diárias dos desocupados e inflamarem até mesmo a imaginação das mulheres e dos camponeses (...)"(grifo meu) ${ }^{73}$.

A expressão "até mesmo" revela que o interesse feminino pelas questões cívicas surpreendeu a sociedade. Realmente o que aconteceu foi novo e extraordinário : mulheres do povo, com pouca instrução, passaram a falar a linguagem dos direitos do homem. Acreditaram que também faziam parte do povo soberano, e podiam participar da grande "reconstrução" da nação. Havia uma dignidade nova na posição da mulher patriota, e ela criou ânimo para conquistar seu espaço. Proponho que, antes de ocupar os espaços políticos reais que surgiram nos desdobramentos da Revolução , essas mulheres conquistaram um espaço moral advindo da Declaração de Direitos do Homem e do Cidadão, cujos princípios inspiravam um respeito quase religioso amplamente difundido na sociedade. O seu Artigo III inflamou os espíritos: " O princípio de toda Soberania reside essencialmente na Nação. Nenhum corpo ou indivíduo pode exercer autoridade que não emane expressamente da Nação" ${ }^{74}$. Jornalistas radicais como Camille Desmoulins iam mais longe: "A soberania reside na cidadania, e ela nunca delega seu poder exceto por mandato... que é revogável pela vontade do povo (...) e a vontade do povo é a lei suprema" ${ }^{75}$. Ora, o direito de revogar o mandato de deputados incompetentes e referendo popular está implícito nesta idéia, defendida mais tarde pelo movimento da sans-culotterie, do qual participaram as mulheres. É natural que elas começassem a assimilar tais mensagens. O primeiro ensaio prático do conceito ocorreu quando as manifestantes parisienses invadiram a Assembléia Nacional em 5 de outubro de 1789.

A idéia da igualdade entre todos os cidadãos seduzia os humildes. A "República da Virtude" oferecia algo que o cristianismo nunca prometeu aos pobres:

\footnotetext{
73 TOCQUEVILLE, Alexis de - L’ancien régime et la Révolution - Gallimard 1967, p. 231.

${ }^{74}$ www.assemblee-nationale.fr/histoire/dudh/1789.

${ }^{75}$ APPLEWHITE, Harriet B. \& LEVY Darline G. "Responses to the Political Activism of Women of the People in Revolutionary Paris, 1789-1793. IN Women and the Structure of Society - Selected research from the fifth Berkshire Conference on the History of Women., edited by Barbara J. Harris and Jo Ann K. McNamara. Duke Press Policy Studies, 1984, p. 216.
} 
poder sobre os grandes no tempo presente, e não uma vaga preferência ${ }^{76}$ por eles na vida eterna. Saint-Just postulava que se os governos e potências terrenas não respondessem adequadamente, "armem o povo, o povo deve reinar"77. Algumas mulheres, como as Republicanas Revolucionárias, ouviram o apelo e reivindicaram o direito de armar-se, prerrogativa da cidadania. Trata-se do direito absoluto da humanidade de rebelar-se contra a tirania desumana.

A seguir , um exemplo de princípios revolucionários colocados em prática no ambiente de trabalho. Devido à crise econômica, o governo abriu oficinas de fiação e costura para empregar as mulheres necessitadas. As Seções de Paris contrataram desempregadas e parentes dos soldados para confeccionar roupas para o exército. Em geral, os salários mal garantiam a subsistência, e as condições de trabalho eram precárias, o que gerou protestos. No Magazin du Temple, onde as operárias costuravam sacos de farinha, não havia aquecimento em pleno inverno. Uma funcionária reclamou que: “ os oficiais municipais e as autoridades não passavam de seus agentes [das funcionária]) e era espantoso que faltasse lenha para o [povo] Soberano enquanto seus agentes estavam dela abundantemente providos" ${ }^{78}$.

A descontente foi despedida junto com sua filha, pois a moça, logo após o incidente, leu a Declaração dos Direitos do Homem e do Cidadão para as colegas de oficina de trabalho. As duas protestaram mais na qualidade de cidadãs que de operárias e recorreram à sociedade popular de seu bairro, que assumiu sua defesa perante os administradores da fiação. Reivindicações de artesãos são anteriores à Revolução, porém agora, vinham acompanhadas da consciência do direito à igualdade no trabalho. A novidade era o uso dos princípios da Declaração de Direitos do Homem e do Cidadão como arma moral e política contra o tratamento indigno das operárias. Aquelas mulheres julgavam que tinham direitos porque pertenciam ao corpo político dos cidadãos. As fiandeiras estavam convencidas do que disse Saint Just:

\footnotetext{
76 "É mais fácil um camelo passar pela cabeça da agulha que um rico entrar no Reino dos Céus". No Evangelho há várias passagens que denotam a preferência de Deus pelos pobres, os injustiçados, os humildes, as crianças.

77 citação de Saint-Just IN BLUM, Carol, Rousseau and the Republic of Virtue - The language of Politics in the French Revolution, Ithaca and London, Cornell University Press, 1986, p. 174.

78 GODINEAU, Dominique, Citoyennes Tricoteuses - Les femmes du peuple à Paris pendant la
} Révolution Française, Paris, Editions Alinea, Perrin, 2004 , pp. 88., 102-103. 
" Os infelizes são os poderosos da terra. Eles têm o direito de falar como senhores aos governos que os esquecem " ${ }^{79}$.

Embora muitas operárias trabalhassem em silêncio, por medo de perder o emprego, outras se insubordinaram contra a administração comunal. Tais movimentos operários, segundo Dominique Godineau, relativizam a imagem da população assalariada dócil, afastada das lutas políticas.

\section{4 - A ruptura com o passado}

As mulheres que apoiaram a Revolução, independente de sua classe social, queriam e precisavam romper com a persistente imagem de egoísmo, vaidade, dissimulação e futilidade associadas ao sexo feminino, para poder integrar-se à nova ordem social. Esse é um dos sentidos da militância política. A imagem negativa emergia com freqüência nos discursos e panfletos masculinos como exemplo de vícios que deviam desaparecer com a regeneração dos costumes. No contexto da nova sociedade que aspirava à virtude, os defeitos atribuídos às aristocratas e à Rainha respingavam no sexo feminino como um todo. Para alguns articulistas, as aristocratas devassas eram culpadas pelo esfacelamento da sociedade monárquica e pela ruína da França do Antigo Regime. O jornalista radical Prudhomme, escreveu no seu jornal Révolutions de Paris em fevereiro de 1791: " O reino das cortesãs precipitou a ruína da nação; o império das Rainhas o consumou (...) a princesa frívola Marie Antoinette (...) aproveitou sua ascendência sobre pequenas coisas para interferir nas grandes e influenciar o destino de todo um povo (...)" ${ }^{80}$.

Os franceses detestavam Maria Antonieta e repudiavam tudo o que ela representava no imaginário popular: a má mãe, a esposa adúltera, a leviandade, o luxo desmedido, a má conselheira do Rei, a estrangeira. Entre outras faltas, era acusada de ensinar o Rei a ser dissimulado, o que significava guardar segredos e mentir. A dissimulação estaria no cerne das conspirações contra-revolucionárias. A acusação era séria, considerando que os revolucionários valorizavam a transparência, virtude

\footnotetext{
79 Relatório de Saint-Just de 8 Ventôse do Ano II IN GODINEAU, Dominique, Citoyennes Tricoteuses - Les femmes du peuple à Paris pendant la Révolution Française, Paris, Editions Alinea, Perrin, 2004 , p. 98.

${ }^{80}$ CENSER, Jack R. and HUNT, Lynn, Liberty, Equality, Fraternity - Exploring the French

Revolution, Pennsylvania, The Pennsylvania State University Press, 2001, pp. 79-81.
} 
considerada essencial para o futuro da República ${ }^{81}$. As críticas vinham dos prestigiosos filósofos (philosophes) do século XVIII: na opinião de Montesquieu e Rousseau, a dissimulação era uma característica feminina, e não apenas aristocrática.. Já havia uma tendência de estender ao sexo feminino os traços negativos das integrantes da aristocracia. François Furet pensa que os ataques verbais a Maria Antonieta eram tão virulentos que poderiam, para além da Rainha, visar todo o sexo, "num tempo que incensa as mães mas não sabe o que fazer com as cidadãs"82. Em vista da mancha de caráter projetada pela Rainha, e em solidariedade ao ódio que lhe devotavam os homens, algumas mulheres faziam questão de desprezar a "prostituta austríaca" , não só por lealdade nacional, mas em sinal de sua pureza pessoal ${ }^{83}$. Durante a invasão ao Palácio das Tulherias em 20 de junho de 1793, uma moça atirou ao chão a touca da Rainha que colocaram em sua cabeça, bradando que como "pessoa honesta" não ia se sujar com aquele adereço ${ }^{84}$.

No Espírito das Leis, Montesquieu declara que os vícios do luxo aristocrático levam à corrupção feminina. A liberdade irrestrita e a vaidade se derramam sobre a esfera pública da corte sempre que cortesãos ambiciosos buscam ascensão através dos ofícios de damas poderosas. Ao contrário, o autor elogia a virtude e a liberdade das mulheres sob constituições republicanas, onde a liberdade é controlada pelos bons costumes (moeurs), e o luxo e o vício são banidos. Ao mesmo tempo, adverte que quando as mulheres estão "fora de seu lugar", os homens são reduzidos a uma posição efeminada e a desordem necessariamente se instala ${ }^{85}$.

Jean-Jacques Rousseau se insurgiu contra a pretensão das mulheres da sociedade parisiense à cultura e saber, e foi o principal crítico das salonnières, que na sua opinião, ensinavam os homens a se promoverem na cena política e cultural através do fingimento e da hipocrisia. O salão literário era a porta de entrada das mulheres na esfera pública, que as corrompia. Assim, a virtude só seria restaurada se as mulheres

\footnotetext{
${ }^{81}$ HUNT, Lynn, The Family Romance of the French Revolution , Los Angeles, University of California Press, 1992 , pp. 96-98.

${ }^{82}$ FURET, Francois, e OZOUF, Mona, Dictionnaire Critique de la Révolution Française: Institutions et Créations, Événements, Idées, Acteurs - Champs, Flammarion 1992, Acteurs, p. 210. ${ }^{83}$ GUTWIRTH, Madelyn, The Twilight of the Goddesses - Women and Representation in the French Revolutionary Era - New Jersey, Rutgers University Press, 1992, p. 243.

${ }^{84}$ ROSA, Annette, Citoyennes, Paris, Messidor, 1988 , p.93.

${ }^{85}$ MONTESQUIEU, L'Esprit des Lois, IN LANDES, Joan B., Women and the Public Sphere in the age of the French Revolution, Ithaca and London, Cornell University Press, 1988 , p. 36.
} 
retornassem para a esfera privada do lar e da família ${ }^{86}$. No Emile, Rousseau propõe o modelo de uma educação feminina exclusivamente voltada para o casamento, a maternidade e domesticidade, pois esse era o caminho para a reforma da sociedade. $\mathrm{Na}$ Carta a d"Alembert, o autor elogia a moral e os costumes dos antigos quando as mulheres viviam reclusas e raramente apareciam em público, ao contrário da França, onde a mulher mais estimada era a mais espalhafatosa, a que se mostrava mais "no mundo" e julgava e assinalava aos talentos os devidos lugares, enquanto os humildes sábios mendigam seus favores ${ }^{87}$. Fénelon, no século precedente, já havia ressuscitado o conceito aristotélico da família como unidade fundamental da vida cívica, e recomendou a volta da mulher para a esfera privada do lar. Daí se deduz que para ele, a ordem social dependia da domesticidade da mulher. Rousseau preconiza a mesma coisa. Politiza o comportamento dos sexos - ou "sexualiza” a política - associando a austeridade republicana de Genebra com masculinidade, e o luxo da monarquia absolutista com feminilidade. Considera que a virtude é masculina e republicana ${ }^{88}$. Para um monarca dá na mesma governar homens ou mulheres, desde que seja obedecido, "mas numa República, precisa-se de homens" 89.

Aqui está a semente do discurso radical da Revolução burguesa dos costumes durante a Revolução Francesa: os homens passaram a representar austeridade, transparência, e liberdade da República, e as mulheres a dissimulação e corrupção do Antigo Regime. Havia se estabelecido uma conexão entre a degradação da mulher , corrupção política, conspiração da aristocracia e enfraquecimento da sociedade francesa, o que gerou uma violenta reação moralista contra a idéia do poder social e político da mulher. Rousseau fez escola: a ligação negativa entre a aristocracia e a feminilidade está presente tanto na retórica como na iconografia revolucionária ${ }^{90}$.

\footnotetext{
${ }^{86}$ HUNT, Lynn, The Family Romance of the French Revolution , Los Angeles, University of California Press, 1992 . p. 98

${ }^{87}$ ROUSSEAU, Jean-Jacques - Lettre à d'Alembert - Flammarion 1967 pp. 114, 115.

${ }^{88}$ ROUSSEAU, Oeuvres Complètes, vol.3 p.139

${ }^{89}$ idem, p. 196.

${ }^{90}$ LANDES, Joan B., Visualizing the Nation - Gender Representation and Revolution in EighteenthCentury France, Ithaca, Cornell University Press, 2001, pp.122-123.
} 
Vejamos o artigo "Por que as mulheres são mais aristocratas que os homens?” do Journal de Perlet de 22 de novembro de $1790{ }^{91}$, no qual o autor supôs que as mulheres detestavam a Revolução porque :

Elas viram que num Estado onde a liberdade política é completa, haveria uma revolução na moral e nos costumes (moeurs) (...) elas seriam obrigadas a substituir seu ócio ruidoso e frívolo e sua independência escandalosa pelos deveres de esposas, de mães e de cidadãs; a honra de se tornarem espartanas não as consola pela perda dos prazeres de Atenas (...) a revolução vai lhes impor o jugo odioso (...) das virtudes, da moral e da fidelidade.

Tudo indica que o autor se refere às aristocratas do Antigo Regime. Depois de criticá-las, aproveita para ensinar-lhes os novos ideais : a honra republicana das esposas, mães e cidadãs. Houve duas respostas a essa carta anônima, ambas defendendo as mulheres, uma elogiando as ativistas populares por sua atuação em prol da "coisa pública" nas jornadas revolucionárias, e outra indignada com a acusação, em pleno século da ilustração, de se supor que o único interesse feminino seja a vaidade, e propõe o sufrágio para ambos os sexos.

A questão da futilidade, do guarda-roupa, e da coqueteria femininas na sociedade revolucionária não é inócua como pode parecer à primeira vista. Muitos eram os que pensavam que os cuidados com a beleza e o gosto dos enfeites eram inerentes ao sexo feminino, em qualquer regime político ou tempo da história. Ao afirmar que as mulheres só se preocupavam com a aparência e com a galanteria masculina, negavam seu interesse pela coisa pública, e sua participação na esfera política revolucionária. Era uma exclusão dupla: a frivolidade não pertencia ao terreno político, e o "eterno espírito feminino" as afastava da reconstrução da cidade. Segundo Godineau, esse era o discurso dominante, porém outros pensavam que nem as mulheres nem os homens podiam escapar das mudanças sociais, e que, de fato, as francesas tinham deixado de ser frívolas, passando a repudiar jóias e fitas como "símbolos vergonhosos" de sua antiga escravidão ${ }^{92}$. Na retórica revolucionária, a mulher livre desprezava a vaidade característica da degradação moral feminina numa

\footnotetext{
${ }^{91}$ Journal de Perlet no. 473, 22 novembre 1790, 5-6 e as cartas ao editor IN LANDES, Joan B., Visualizing the Nation - Gender Representation and Revolution in Eighteenth-Century France, Ithaca, Cornell University Press, 2001, pp. 215-216.

92 GODINEAU, Dominique, « Histoire sociale, histoire culturelle, histoire politique : la question du droit de cité des femmes » IN LAPIED, Martine e PEYRARD Christine (direction) Préface VOVELLE, Michel , La Révolution Française au Carrefour des Recherches , Aix-en Provence , Publications de l’Université de Provence, 2003,pp. 300-301.
} 
sociedade escravizada ${ }^{93}$. De fato, conforme algumas declarações já citadas anteriormente neste trabalho, as patriotas se valeram da recém-descoberta liberdade para dedicar-se à causa pública. As militantes se integraram na nova sociedade através da ação política, embora muitas afirmassem que também eram esposas e mães devotadas à família. A maternidade conferia respeitabilidade moral, e no início da Revolução, ainda não existia a percepção de incompatibilidade entre esses papéis.

\section{$\underline{1.5}$ - A maternidade cívica}

Não obstante, a maioria das francesas concordava com os homens que não viam com bons olhos a participação feminina na vida política. Elas escolheram o caminho da maternidade para expressar seu patriotismo, conforme preconizava a ideologia revolucionária dominante, herdeira das teorias iluministas sobre a regeneração moral na sociedade. A volta das mulheres aos seus deveres maternos e a devoção à família estavam na base dessa idéia. Jean-Jacques Rousseau realçou a importância materna na educação dos filhos pequenos: " a primeira educação dos homens depende dos cuidados da mãe; das mulheres dependem também sua moral, suas paixões, gostos, prazeres e até a felicidade. Assim, toda a educação das mulheres tem que ser relativa aos homens" (Emile, livre V) ${ }^{94}$. No espírito rousseauísta, um líder de seção de Orléans explicou em 1792 o que entendia por educação: "As mães ensinarão às crianças a falar desde cedo a linguagem máscula da liberdade" ${ }^{95}$. Como fazer isso? Para ajudar as mães a formarem cidadãos, apareceram várias publicações dirigidas a elas, como “O verdadeiro amigo da Rainha, ou o Jornal das damas - por uma sociedade de cidadãs" :

(...) desde que os esposos de nossas companheiras são homens, \& que seus filhos são homens para educar,(...) a caixa de rouge e os pompons estão esquecidos (...) sobre sua mesa de toilette , é o "Moniteur" (jornal oficial do governo revolucionário - parêntese meu) que encontramos; o Jornal das Damas, de hoje em diante tem que ser sério para agradar essas

\footnotetext{
93 GODINEAU, Dominique, "De la rosière à la tricoteuse: les représentations de la femme du peuple à la fin de l'ancien Régime et pendant la Révolution" p. 7 , http://revolution-francaise.net/2008/05/01/229rosiere-a-tricoteuse-representation-femme-peuple. Acesso em : 11 maio 2009.

${ }^{94}$ KIEBIEHLER, Yvonne, Histoire des Mères et de la Maternité en Occident, Paris, PUF 2004, pp. 59-69.

95 PROCTOR, Candice E., Women, Equality and the French Revolution, chapter "The Cult of Republican Motherhood", Contribution in Women's Studies, no. 115, Greeenwood Press, p. 127.
} 
mulheres, tem que ser uma publicação patriótica que a mãe possa colocar nas mãos de sua filha (...) vamos lhes apresentar um jornal (...) que exprima os sentimentos patrióticos como as mulheres os expressam (...) com doçura e emoção ${ }^{96}$.

A mensagem é que a Revolução teria transformado o caráter das pessoas. Os companheiros e filhos eram agora verdadeiros homens e as mulheres trocaram a futilidade dos pompons pelo desvelo na educação dos filhos - mas com um toque de sentimentalismo, supostamente para agradar as leitoras. A devoção total da mãe à criança tornou-se um valor de civilização e um código de boa conduta, além de manifestação de patriotismo. Mais uma vez, a vida privada e a pública se misturam.

As virtudes das patriotas deviam ser o oposto das características atribuídas às mulheres do Antigo Regime, de acordo com o jornalista Prudhomme: " As virtudes mais agradáveis numa mulher, e as que mais atraem as homenagens e o respeito dos homens não são o pudor, o cuidado na amamentação e criação dos filhos, a vigilância sobre o lar, e a contribuição para a felicidade do marido?"17 Prudomme, inspirado em Rousseau como outros revolucionários, queria recriar uma visão gloriosa da Roma Republicana , onde o homens eram viris e as mulheres submissas e restritas ao lar. Os modelos a serem copiados pelas francesas eram Pórcia, que não pensava em política e seguia docilmente a opinião dos homens da família, e a famosa Cornélia, elogiada por um orador do Cercle Social: "o trono de uma mulher está no seio da família. Cornélia não era nem general, nem consul, nem senador, era a mãe dos

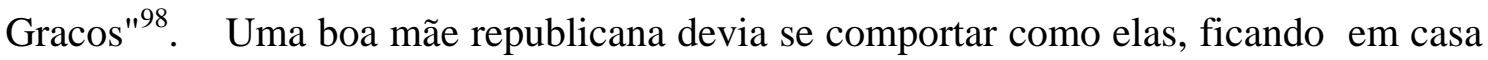
cuidando dos filhos, seu lugar não era nas tribunas das assembléias nem nas manifestações de rua.

\footnotetext{
${ }^{96}$ Le Véritable ami de la Reine ou Journal des Dames par une Société de Citoyennes - Paris, 1790, microficha 9.4/173 IN LUCAS, Colin, Editor-in-Chief The French Revolution Research Collection, University of Chicago, 1992 , The New York Public Library.

${ }^{97}$ Panfleto Adresse au beau sexe, rélativement à la révolution présente IN PROCTOR, Candice E., Women, Equality and the French Revolution, Contribution in Women's Studies, no. 115, Greeenwood Press , pp. 56-57.

${ }^{98}$ AULARD, F. A. Paris Pendant la réaction thermidorienne et sous le Directoire: Recueil de documents, vol. 3, p. 548, vol. 4, p. 624. IN PROCTOR, Candice E., Women, Equality and the French Revolution, Chapter "The Cult of Republican Motherhood' , Contribution in Women's Studies, no. 115, Greeenwood Press, p. 57.
} 
A partir de 1792, a França estava em guerra e precisava de combatentes para defendê-la , e as mulheres foram chamadas a dar à luz a um "povo de heróis"99, como disse Hérault de Séchelles, Presidente da Convenção. As mulheres grávidas eram "alegorias à perenidade da Revolução" e num projeto de festa cívica, Chaumette propôs instalá-las numa tribuna com os dizeres: "respeito às mulheres grávidas, esperança da pátria"100. Indo além da simples função geradora, as mulheres eram fundamentais na formação moral do novo homem, pedra de toque na construção de uma nova sociedade mais virtuosa e feliz. As mães patriotas não apenas criavam prosaicamente os filhos, estavam num patamar mais elevado, pois ensinavam os princípios republicanos aos futuros cidadãos franceses. Na visão revolucionária da divisão sexual de tarefas, os homens faziam as leis e as mulheres faziam os costumes. Não era pouco. A mulher continuava subordinada ao homem, porém exaltada como mãe e educadora. Em vista disso, conforme Godineau ressaltou, seria empobrecedor pensar que esse "culto à maternidade" por parte dos dirigentes revolucionários fosse apenas uma maneira de alijar as mulheres da cena pública, embora os deveres maternos tivessem sido invocados para justificar a exclusão política feminina ${ }^{101}$. A sociedade de fato reconhecia a importância do papel materno, e há testemunhos desse sentimento nas mais inusitadas circunstâncias. Madame de la Tour du Pin relatou que quando tinha acabado de dar à luz num subúrbio de Bordeaux, onde estava refugiada sob falsa identidade, sua casa foi invadida por um bando de "corta-cabeças". Aqueles "seres ferozes" tiveram compaixão por ela e seu bebê , e até delicadeza, tirando os tamancos de madeira para não fazer barulho perto de seu quarto. Durante toda a Revolução, as mulheres assumiram o papel de mães com orgulho. A Mère Duchesne observou: " se as crianças devem beber com o leite os princípios da Constituição, quem pode e deve catequizá-las nessa circunstância?" [a mãe] . Pondera que é a mãe que faz germinar em seus corações o amor da liberdade, e se ela prestasse apenas esse serviço à nação, já teria feito o bastante pela Revolução. A literatura também reproduziu o clima da época : o personagem principal da obra Les dieux on soif, Gamelin, no decorrer da Revolução se transforma aos poucos num fanático impiedoso. Porém, quando ele se

\footnotetext{
${ }^{99}$ LEVY, Darline G. e APPLEWHITE Harriet B. "Women and Militant citizenship in Revolutionary Paris” IN MELZER, Sara E. And RABINE, Leslie W. (editoras), Rebel Daughters -Women and the French Revolution, New York - Oxford, Oxford University Press, 1992, p. 94.

${ }^{100}$ Segundo La Gazette française no. 703 (11 frimaire an II) IN GODINEAU, Dominique, Citoyennes Tricoteuses - Les femmes du peuple à Paris pendant la Révolution Française, Paris, Editions Alinea, Perrin, 2004 , p. 43.

101 GODINEAU, Dominique, Citoyennes Tricoteuses - Les femmes du peuple à Paris pendant la
} Révolution Française, Paris, Editions Alinea, Perrin, 2004, p. 43. 
deparou na rua com a citoyenne Dumonteil, famélica, olhar vago, mal nutrida a ponto de não poder amamentar seu filho, deu metade de seu pão à infeliz, e passou fome ele próprio aquela noite ${ }^{102}$. A maternidade despertava ternura até nos piores sanguinários.

Lynn Hunt ${ }^{103}$ observa que, apesar do interesse de estudiosos pelo tema da maternidade republicana, não há muitos trabalhos a respeito: uma exceção é o estudo de Candice Proctor "The Cult of Republican Motherhood"104. Ela própria vê poucas evidências de uma campanha de propaganda sistemática da maternidade republicana na França. As militantes sempre se referiam à importância do papel das mães educadoras, mas organizaram poucos programas educativos para as crianças. A opinião de Hunt é de que a maternidade republicana foi defendida pelos homens, principalmente os que detestavam os clubes políticos femininos, sempre que precisaram justificar sua rejeição à participação política das ativistas. Não posso avaliar se houve tal "campanha sistemática" pela documentação escrita que consultei. É possível constatar, entretanto, nas declarações de diversos líderes revolucionários, jornalistas, militantes, mães e cidadãos, que havia um enorme entusiasmo e respeito pelo conceito novo da maternidade cívica e da família. Em seu relatório de 7 de maio de 1794, Robespierre propôs festivais dedicados à celebração do amor, da fidelidade conjugal, afeto paternal, amor materno, piedade filial, entre outros ${ }^{105}$. Tamanha glorificação era um componente essencial do programa de transformação moral da nação conhecido por República da Virtude. Dhaussy e Verjus vêem uma política de "matrimonialização" da cidadania, apresentada como o remédio mais eficaz contra as antigas práticas libertinas (...) que permite situar as mulheres no processo de construção política da democracia ${ }^{106}$. O modo de pensar sobre a família e a maternidade havia mudado em relação ao Antigo Regime. E penso que a iconografia revolucionária

${ }^{102}$ FRANCE, Anatole, Les dieux ont soif, Paris, Gallimard, 1989, p. 98.

${ }^{103}$ HUNT, Lynn, "Male Virtue and Republican Motherhood" IN BAKER, Michael K., The French

Revolution and the Creation of Modern Political Culture, New York, Elsevier Science Ltd, Pergamon, 1994, vol. 4 "The Terror", pp. 210-202.

${ }^{104}$ PROCTOR, Candice E., "The Cult of Republican Motherhood" IN Women, Equality and the French Revolution, Contribution in Women's Studies, no. 115, Greeenwood Press .

${ }^{105}$ HUNT, Lynn, "Male Virtue and Republican Motherhood" IN BAKER, Michael K., The French Revolution and the Creation of Modern Political Culture, New York, Elsevier Science Ltd, Pergamon , 1994, vol. 4 "The Terror", pp. 200-201.

${ }^{106}$ DHAUSSY, Catherine, e VERJUS, Anne "De l'action féminine en période de révolte (s) et de révolution (s) AHRF NO. 312, 1988, No. 1- http://dhaussy.verjus.free.fr/html/action.femmes.html 
teve papel significativo na formação da nova mentalidade, sendo naturalmente também influenciada por ela. As deusas da antigüidade greco-romana e as mães se tornaram os novos símbolos da nação, como se depreende das representações. A exaltação dessas imagens femininas pode ser considerada uma campanha educativa para promover os novos comportamentos republicanos. O resultado desse esforço concertado levou a uma percepção amplamente compartilhada na sociedade da respeitabilidade moral das mães de família. Lynn Hunt salientou que nos últimos anos da década de 1790 a imagem da boa mãe que conhece seu lugar na família havia se estabelecido firmemente, apesar de que considera difícil correlacionar a imagem com as alterações demográficas - entretanto notou que cresceu o número de casamentos do início do reinado de Luís XVI até $1794^{107}$. A família tinha-se tornado o símbolo da harmonia social. Penso que em larga medida pode-se atribuir o fato ao êxito da campanha jacobina de reforma dos costumes e do culto à maternidade para a consolidação da república francesa. Mercier celebrou a nova família moralizada em 1798:

"onde quer que eu olhe, vejo crianças em todos os lugares nos braços de todas as mulheres; até os homens estão carregando essas inocentes criaturas...Nunca em outra cidade (...) fiquei tão impressionado com o número de crianças. (...) todas as nossas mulheres francesas amamentam, todas se sentem honradas em ser mães e todas acham que a única boa nutriz é a mãe verdadeira".

Com otimismo precipitado, o autor achou que a era das amas-de-leite e da severidade com as crianças tinha acabado ${ }^{108}$.

Toda a questão da maternidade cívica está permeada pela porosidade das fronteiras entre a família e o Estado. Dorinda Outram ${ }^{109}$ propõe que a virtude pessoal da mulher (virtude:castidade) leva à virtude política (virtude: prezar os interesses do

\footnotetext{
${ }^{107}$ HUNT, Lynn, The Family Romance of the French Revolution , Los Angeles, University of California Press, 1992 , p. 160

108 Louis-Sébastien Mercier, Le Nouveau Paris (Paris, au VII [1799], vol. 3, pp. 191-94 IN HUNT, Lynn, The Family Romance of the French Revolution , Los Angeles, University of California Press, 1992 , p. 160.

${ }^{109}$ OUTRAM, Dorinda, "Le langage mâle de la vertu: Women and the discourse of the French Revolution" IN BURKE, Peter , PORTER, Roy, The Social History of Language, Melbourne, Cambridge University Press, 1987, p. 125.
} 
Estado acima dos pessoais). Daí se deduz a importância do comportamento virtuoso feminino para o corpo social, e o seu oposto, a desordem moral da mulher que leva à corrupção política da sociedade, tal como no Antigo Regime. Num paroxismo de confusão entre a vida privada e a pública, uma mulher devassa solapa as bases da República, é uma traidora. A maternidade e a amamentação, que antes eram funções da vida particular, se tornaram assunto de interesse público. Entretanto, é preciso levar em conta que no século dezoito, os serviços das amas-de-leite eram uma instituição social e uma profissão regulamentada pelo Estado, o que matiza a idéia do "particular" e do "público"110. No século das Luzes muitos pensadores defenderam o aleitamento materno, o que reflete uma mudança de atitude nas relações familiares. O costume de enviar o recém-nascido para uma ama-de-leite no campo foi denunciado com indignação. Em 1746, Madame d"Épinay deu à luz ao seu primeiro filho e ao manifestar o desejo de aleitá-lo pessoalmente, foi ridicularizada pelo marido, o qual a proibiu de fazê-lo, pois era uma atividade para "camareiras", "indigna de uma mulher de posição"111.

Uma obra amplamente difundida, Conselhos às Mães (Avis aux Mères) de Le Rebours, endossada pela Faculdade de Medicina de Paris, dizia que o leite mercenário era "bastardo" e pervertia a nobreza natural do homem, seu corpo e seu espírito - era uma alimentação degenerada como as próprias amas-de- leite, que na sua opinião podiam infectar a criança com seu sangue impuro e contagioso. As recomendações médicas visavam a redução da escandalosa mortalidade infantil, pois percebeu-se que o "menino era pai do homem", ou seja, a saúde moral e física do adulto dependia dos cuidados que recebeu na infância. O grande defensor do amor e do aleitamento maternos foi Jean-Jacques Rousseau. Para ele, uma mulher que se recusasse a amamentar seu bebê estaria traindo a natureza, principalmente devido aos laços afetivos que se formam com o contato carnal entre a mãe e a criança. Tanto para Rousseau como para Le Rebours, o aleitamento materno criava uma unidade familiar imune à corrupção. As mulheres esclarecidas das classes superiores e da burguesia responderam ao apelo antes das mães operárias, que precisavam trabalhar e não podiam

\footnotetext{
${ }^{110}$ JACOBUS, Mary, "Incorruptible Milk: breast-feeding and the French Revolution' IN MELZER, Sara E. And RABINE, Leslie W. (editoras), Rebel Daughters -Women and the French Revolution, New York - Oxford, Oxford University Press, 1992, p. 54 - 61.

${ }^{111}$ BADINTER, Elisabeth, Émilie, Émilie - A ambição feminina no século XVIII - São Paulo, Discurso Editorial, 2003, p. 112-113.
} 
amamentar $^{112}$. Mas a mudança se impôs entre as últimas décadas do Antigo Regime e a Revolução.

Já em 1791, as mães de Clermont-Ferrand escreveram para a Assembléia Nacional: "Nós amamentamos nossas crianças com um leite incorruptível que clareamos com o espírito natural e agradável da liberdade"113. Os deputados aplaudiram as mães que cumpriam seu dever - mas não deixa de ser curioso o fato de elas terem escrito à Assembléia Nacional para informar o fato. As mulheres haviam conquistado o direito de se manifestar nesse espaço político sobre uma variedade de questões e não perdiam oportunidade de fazê-lo. Depois da glorificação das mães, chegou a vez do leite materno, o qual era tido como veículo de qualidades morais. A expressão "mamar os princípios republicanos junto com o leite" tornou-se lugar comum. A iconografia registrou a Festa da Constituição de 10 de agosto de 1793, na qual uma gigantesca estátua "egípcia" espirrava leite de suas mamas ${ }^{114}$. Saint-Just achava que as crianças pertenciam às suas mães desde que ela os amamentasse pessoalmente até os cinco anos de idade; depois disso pertenciam à República até a morte; as mães que não amamentassem seus filhos deixavam de ser mães aos olhos da pátria; a criança e o cidadão pertencem à pátria (...)" ${ }^{115}$. Saint-Just também declarou à Convenção: "A felicidade é uma idéia nova na Europa". Não se referia à felicidade particular, mas sim às condições sociais e políticas que devem permitir a felicidade de todos os cidadãos - o bonheur commun - era de fato uma idéia nova (século XVIII) e consta do preâmbulo da Declaração dos Direitos do Homem e do Cidadão ${ }^{116}$. As boas mães republicanas ajudariam a construir uma sociedade na qual as crianças se desenvolveriam nas melhores condições possíveis, num ambiente de liberdade e igualdade. A vocação da mulher era governar a casa, enquanto os homens legislavam e governavam a nação. Revoltar-se contra essa ordem estabelecida não só era uma

\footnotetext{
112 JACOBUS, Mary, "Incorruptible Milk: breat-feeding and the French Revolution' IN MELZER, Sara E. And RABINE, Leslie W. (editoras), Rebel Daughters -Women and the French Revolution, New York - Oxford, Oxford University Press, 1992, p. 54.

113 JACOBUS, Mary, "Incorruptible Milk: breat-feeding and the French Revolution' IN MELZER, Sara E. And RABINE, Leslie W. (editoras), Rebel Daughters -Women and the French Revolution, New York - Oxford, Oxford University Press, 1992, p. 54.

${ }^{114}$ Esta gravura está incluída no Capítulo 2.

${ }^{115}$ SAINT-JUST, Republican Institutes J.H. Robinson ed. Readings in European History 2 vols.(Boston:Ginn, 1906) < history.hanover.edu/texts/stjust.html > acesso em 26/8/08.

${ }^{116}$ THEURIOT, F. , "La conception Robespierriste du bonheur" IN Annales Historiques de la Révolution Française (AHRF) , no. 191 (quarantième année) jan-mars, 1968, p. 207.
} 
atitude anti-cristã e anti-natural, mas também impatriótica. A esterilidade natural era uma infelicidade, mas a tentativa de limitar o número de filhos era criminosa e, claro, impatriótica.

Em compensação, as mães, inclusive das classes populares, passaram a ter mais autoridade sobre os filhos, eram respeitadas por seus conhecimentos de puericultura, tinham lugar de honra nos festivais, eram chamadas de cidadãs, e isso lhes conferia dignidade. Havia uma vontade nova entre elas de educar seus filhos pessoalmente, para a felicidade deles e de todos, afastando-os das superstições das amas-de-leite e comadres. O juramento que os membros do Clube das Lionesas faziam une a maternidade e o civismo: " Juro ensinar aos meus filhos e outros sob minha autoridade que devem preferir a morte à escravidão"117. As mulheres francesas aceitaram a maternidade cívica como um meio honroso de participar da comunidade revolucionária. O título de cidadãs era plenamente justificado pela dimensão pública da maternidade, mas por outro lado estava ligado a um estado civil.

$\mathrm{Na}$ prática, as mães se transformaram em categoria social e política. Robespierre se refere a elas como categoria, ao responder a uma deputação de membros da Sociedade das Republicanas Revolucionárias em 26 de agosto de 1793: "(...) vocês descobriram gente malvada, inimigos do povo, mas não é entre as mães de família que poderíamos encontrá-los, elas conservam seu espírito para a execução das leis e dos princípios (...)" Robespierre fez a afirmação invocando todo o peso dos "verdadeiros patriotas" da Assembléia, que "se apoiará sempre sobre a força do povo"118. A designação genérica " mães" transcende classe social e ocupação, e configura uma categoria social e política. O patriotismo daquelas mães de família, estava acima de qualquer suspeita, pois elas usavam suas energias para "executar leis e princípios", ou seja, elas viviam a Revolução. E mais: seus atos tinham o respaldo da Assembléia apoiada pelo povo, ao qual elas pertenciam. A defesa de Robespierre se baseou nas qualidades morais inerentes à condição materna. Ademais, elas não podiam ser inimigas do povo, pois eram o povo. Entretanto, durante o Terror, as mães acusadas de traição não se livraram do cadafalso, como Madame Roland e Lucille Desmoulins. A única razão para o adiamento da execução era a constatação de

\footnotetext{
${ }^{117}$ ROSA, Annette, Citoyennes, Paris, Messidor, 1988, p. 228.

${ }^{118}$ Mercure Universel, t. XXX - p. 416
} 
gravidez. Há um estudo de Stephanie Brown salientando que o tribunal revolucionário de Paris julgou 325 mulheres por atividades políticas alegadamente nocivas à Revolução. Entre as julgadas, Brown relaciona 30\% acusadas de inteligência com o inimigo, 23\% denunciadas por opiniões contra-revolucionárias e 15 \% por conspiração. Não sei quantas mães havia nesse grupo, pois não tive acesso a esse trabalho citado por L. Hunt ${ }^{119}$. O Terror minou o entusiasmo das mulheres pela República da Virtude ${ }^{120}$.

Mas antes disso, a glorificação foi tamanha que algumas mães de família quiseram manifestar publicamente a sua dedicação à pátria. Encontrei na documentação vários exemplos de atos públicos de civismo por parte das esposas e mães republicanas. O fato me chamou a atenção pois não deixa de ser irônico que para comprovar seu ardor patriótico, elas tenham ousado deixar seus lares para se apresentar no espaço público das assembléias e dos clubes políticos. Sinal de que as mulheres assimilaram a doutrinação enfática da maternidade cívica, tanto a parte substantiva da "maternidade", como a parte qualificativa de "cívica". Embora nessas ocasiões professassem os mais sinceros princípios republicanos, o faziam na esfera pública eminentemente masculina, em vez de se limitarem ao espaço doméstico, o que transgredia o princípio basilar da domesticidade e da modéstia femininas. Mas como fariam as mães para ensinar os princípios revolucionários aos filhos se elas próprias não os aprendessem? E como aprender sem freqüentar as tribunas, ler os jornais, ouvir discursos, participar das discussões? A resposta de Prudhomme era clara, elas deviam " ter confiança inteira, quase cega (grifo meu) nos homens ligados a elas pelos laços de coração ou de sangue", ouvindo deles os relatos, e seguindo à risca todas as suas recomendações, tal qual fazia a romana Pórcia. Senão " ao querer trocar de papel conosco, temam destruir de um lado o que nós construímos do outro". Aqui já aparece a preocupação com a perigosa "troca de papéis" que tanto assustava uma parte dos homens da época. O jornalista radical se opunha à presença de mulheres peticionárias nas assembléias, ou das que vinham à tribuna debater com deputados. Mesmo no caso das esposas dos artistas de Paris, que se dirigiram à Assembléia Nacional para doar

\footnotetext{
${ }^{119}$ BROWN, Stephanie, Women on Trial: The Revolutionary Tribunal and Gender, PhD theses, Stanford University, 1996 (p. 2) IN HUNT, Lynn, capítulo "L'Histoire des femmes: accomplissements et ouverture" IN LAPIED, Martine, PEYRARD, Christine, La Révolution Française au carrefour des recherches , Aix-en-Provence, Publications de l'Université de Provence, 2003, p. 288.
} 
as suas jóias à nação e foram homenageadas com coroas cívicas, ele achou que elas teriam feito melhor se não tivessem saído de casa. Afinal, poderiam ter enviado os objetos pelos respectivos maridos ou parentes, e depois ouvido deles a repercussão agradável de seu generoso gesto ${ }^{121}$.

A maioria das mães de família não participava da política e se contentava com a vida no espaço doméstico ou no bairro. Algumas, entretanto, sentiram necessidade de um engajamento que ultrapassava o círculo familiar e dos vizinhos. $\underline{\text { Proponho a idéia }}$ de que elas adotaram uma espécie de "maternidade militante", o que pode parecer um paradoxo, pois a militância política não combinava com o conceito republicano de maternidade. Todavia, em meio às tensões revolucionárias surgiam espaços para a ação e o debate, e as práticas eram mais flexíveis que os preceitos e as leis. Situo esse tipo de ação feminina no âmbito da ideologia republicana da transparência e da ligação estreita entre a esfera pública e a privada. Se a pátria era a extensão da família, algumas mães acharam importante pronunciar-se acerca de assuntos públicos que as afetavam, ainda que dentro dos limites da discrição e reconhecendo o terreno como masculino. As relações familiares eram do interesse do Estado: os cidadãos e cidadãs respondiam perante a nação sobre sua moral e bons costumes. Na França, a virtude se exercia em público, não era apenas uma qualidade pessoal. A República da Virtude invadia o lar.

Depois de Termidor tal intrusão na privacidade dos indivíduos se tornou insuportável. $\quad$ Com o fim do período mais radical da Revolução, diminuiu a confraternização que caracterizava o modo de ser dos "sans-culotte", seres gregários que não separavam a moral privada da pública: "ele relata tudo à massa comum: as alegrias, sentimentos de dor (...) aí está a fonte da publicidade que distingue o governo fraternal, isto é, republicano". Eles queriam a moralização da política e a politização do cidadão: era necessário ser bom pai, bom filho para ser patriota ${ }^{122}$. O governo termidoriano marcou a vitória dos moderados da classe burguesa, a qual sempre preferiu a discrição e a separação entre a esfera privada e a vida pública. Diderot

121 Jornal Révolutions de Paris no. 124, 1791, artigo "Das mulheres peticionárias" IN LUCAS, Colin, Editor-in-Chief The French Revolution Research Collection, University of Chicago, 1992, The New York Public Library, microficha 9.4/45.

122 Verbete "Sans-culottes" , Acteurs, FURET, Francois, e OZOUF, Mona, Dictionnaire Critique de la Révolution Française: Institutions et Créations, Événements, Idées, Acteurs - Champs, Flammarion 1992., pp. 427-429. 
explicou como ninguém, na carta à sua filha recém-casada, que as relações familiares deveriam ser um "mistério" para todas as outras pessoas ${ }^{123}$. Lynn Hunt acha que a mudança de sensibilidade em relação à privacidade anunciava o movimento romântico do "fechamento do indivíduo sobre si mesmo e da dedicação à família, num espaço doméstico determinado com maior precisão"124.

No caso das "mães militantes", o que não se esperava era o trânsito no sentido inverso, do lar para a esfera política. Tudo indica que esta atuação seja pontual e esporádica, e não configura uma verdadeira militância, pois segundo a definição de Godineau, a militância é assídua, e muitas vezes exercida através de associações políticas femininas. Entretanto, quando as "mães militantes" intervieram no espaço quintessencialmente masculino, e em tom contestatório, causaram desconforto e o antigo temor da troca de papéis. Nessas circunstâncias, assemelhavam-se às "militantes mães", ou seja, aquelas ativistas que tinham filhos. Em vários casos, fica difícil separar as militantes das mães, porque todas agitavam a bandeira da maternidade republicana, todas eram mães educadoras. As preocupações familiares e reivindicações cívicas se embaralhavam. Penso que as mães e as militantes, na medida em que atuaram politicamente, são duas faces da mesma moeda. As mulheres que se engajaram na política não viam nenhuma incompatibilidade entre as duas funções, ou condições sociais. Tal era a visão dos defensores da cidadania feminina, como Condorcet e Guyomar, Olympe de Gouges e Pauline León. Para os adversários dessa causa, o que separava as mulheres virtuosas das outras era a atuação no espaço político. A exaltação da maternidade estava reservada àquelas que se mantinham com discrição na esfera privada, enquanto todas as que se expuseram na esfera pública foram reprimidas, independente de seu estado civil ou estatuto materno.

Vejamos o documento de 29 de março de 1790: Carta de Brigent Baudouin esposa de um funcionário municipal de Lannion (Bretanha), à Assembléia Nacional, e outros nomes femininos, pedindo que as mulheres sejam admitidas à prestação do

\footnotetext{
${ }^{123}$ A carta de Diderot está comentada na Conclusão da dissertação, e anexada ao trabalho (Anexo B)

${ }^{124}$ HUNT, Lynn , "Revolução Francesa e Vida Privada", IN História da Vida Privada, vol. 4, São Paulo, Cia. das Letras, 2006, p. 21.
} 
juramento cívico (serment civique) ${ }^{125}$. A seguinte carta foi lida na Assembléia, a signatária não estava presente:

Sr. Presidente, não há nenhuma palavra sobre as mulheres na Constituição, e confesso que elas não teriam capacidade de se imiscuir nos assuntos públicos, porém, as mães de família podem e devem ser cidadãs, qual será a que não quer imitar a nossa Rainha, que prometeu educar seu augusto filho nos princípios da nova constituição? Penetrada, afetada por essa declaração patriótica, mãe de dez filhos, e amamentando o mais novo, os reuni em torno de mim (...) e jurei de joelhos diante de Deus educá-los dentro da fidelidade à nação e ao Rei. Minha filha mais velha fez o mesmo juramento porque também é mãe e amamenta seu bebê. Eu ficaria desolada , Sr. Presidente, se esta ação desagradasse à Assembléia Nacional. (...) ouso esperar que, ao contrário, ela emita uma disposição que permita às mães prestar esse juramento solene perante os oficiais municipais que nós estimaremos porque de hoje em diante serão escolhidos pelo povo. Imagino que esta cerimônia respeitável tornará a maternidade recomendável e inculcará os deveres cívicos nas primeiras mestras ${ }^{126}$ dos cidadãos.

Brigent Baudouin teve coragem de apontar a ausência das mulheres no texto constitucional aos deputados da Assembléia Nacional; ela poderia ter se dirigido às instâncias de poder local, mas dessa forma, revestiu seu pedido de um alcance nacional. Para ela, as mães de família podem e devem ser cidadãs, porque são patriotas respeitáveis, querem imitar a Rainha. Elas seriam exemplo para outras mulheres. A signatária tem as melhores credenciais: número de filhos, bom exemplo à sua filha mais velha, amamenta seus bebês, e é fiel à nação, ao Rei e a Deus. O juramento solene inspiraria os deveres cívicos nas mães e tornaria a maternidade recomendável. Mas também emprestaria legitimidade à reivindicação de cidadania feminina. Talvez se fossem tratadas como cidadãs, eventualmente seriam incluídas na categoria dos cidadãos. O juramento solene as elevaria a outro patamar político e social - ficaria difícil recusar-lhes o título oficial de citoyenne. Mas a signatária sabe que está pisando em terreno movediço, teme desagradar à Assembléia, como de fato ocorreu. Na discussão que se seguiu à leitura da carta, um deputado foi favorável ao juramento das mulheres, enquanto outro denunciou " uma inquisição terrível" . O pedido foi votado e adiado. Brigent tinha aguda consciência política, como demonstra a escolha do foro, a natureza do pedido - que de fato tinha objetivos ambiciosos - as razões apresentadas e respostas às possíveis objeções. Durante toda a época revolucionária, o juramento cívico foi muito importante, pois tinha valor sagrado e emprestava uma garantia de fidelidade à palavra dada. O primeiro e mais célebre foi o Juramento do Jeu

\footnotetext{
${ }^{125}$ Documento IN Annales historiques de la Révolution Française (AHRF) no. 322 - Sources, Archives Parlementaires, t.XII, p. 402.

126 "primeiras mestras" são as mães, consideradas as primeiras educadoras de seus filhos pequenos.
} 
de Paume em 20 de junho de $1789^{127}$. Brigent pediu cidadania só para as mães de família, as quais reconhecidamente mereciam mais respeito que as outras mulheres - ou seja, a cidadania era prerrogativa de um estado civil, supondo-se que todas fossem casadas. Por sua vez, as feministas que reivindicaram a cidadania feminina fizeramno em nome de todas as mulheres.

Outro documento interessante é o "Discurso proferido pelas cidadãs da rua do Regard no Clube dos Cordeliers em 22 de fevereiro de 1791"128. As "mães militantes" e citoyennes em questão moravam no Faubourg Saint-Germain, eram das classes populares, e vieram exortar seus irmãos do clube a serem mais enérgicos em relação aos aristocratas e outros inimigos da Revolução. Essas mulheres são esposas e mães, porém ameaçam os homens - que consideram indolentes - de se envolver na luta política se eles não defenderem a pátria:

"No seio de nosso lar, ensinando nossos filhos a saber de cor os princípios sagrados da constituição (...) que os nossos maridos e irmãos juraram proteger, soubemos com pesar e medo da destruição que ameaça a pátria (...) onde estão os homens do 14 de julho? onde está essa família de vinte e cinco milhões de irmãos que prometeram voar em socorro de nosso lar comum em tempos de calamidade? Nós também, nós somos dignas de combater e morrer pela pátria. (grifo meu) Escutem, irmãos do Clube dos Cordeliers, deixamos por alguns instantes o retiro onde estamos relegadas pelos nossos deveres maternos, trabalhos domésticos, nos reunimos e falamos das desgraças que nos afligem por todos os lados (...) e aqui está o que dizem suas irmãs , as Cidadãs da Rua do Regard: não confiem nos homens pérfidos que vos convidam à segurança da morte; fujam das palavras eloqüentes, só falem para agir; nós os seguiremos dia e noite, e pobre daquele que deixar o barco se partir antes de pedir ajuda à força pública; permaneçam armados; o inimigo vos arrastará de volta para a escravidão quando estiverem distraídos cantando hinos à liberdade. Até agora tivemos orgulho em ser chamadas de suas companheiras. Consolamo-nos de nossa inabilidade de contribuir para o bem público elevando o espírito de nossas crianças à altura dos homens livres. Mas, se vocês desapontarem nossas esperanças (...) o desespero e a indignação nos impelirão para as praças públicas onde combateremos pela defesa da liberdade (...) Até conquistarem-na não serão homens (...) Nós salvaremos a pátria ou morreremos com ela(...) Saudações e perseverança aos nossos bravos irmãos do Clube dos Cordeliers" Seguem-se dezenove assinaturas femininas, e um interessante comentário do relator da sessão do clube, o "vosso irmão Kolly" : "depois de uma manifestação tão vigorosa dos sentimentos das mulheres-homens, os homens-mulheres têm que se calar e enrubescer" .

${ }^{127}$ TULARD, J., FAYARD, J.F., FIERRO, A. - Histoire et dictionnaire de la Révolution Française 1789-1799. Ed. Robert Laffont, 1988, verbete "serments civiques", p. 1095.

${ }^{128}$ Documento publicado no Mercure National et Révolutions de L'Europe, Journal Démocratique, No. XVI, 1 de março de 1791. - IN LUCAS, Colin, Editor-in-Chief The French Revolution

Research Collection, University of Chicago, 1992 , The New York Public Library , microficha no. 9.4/33. O mesmo documento traduzido para inglês não contém o comentário importante do relator Kolly, ver LEVY, Darline G., APPLEWHITE, Harriet B., JOHNSON, Mary D. - Women in Revolutionary Paris - 1789-1795 - . Selected documents translated with notes and commentary by the authors - Urbana e Chicago, University of Illinois Press, 1980. 
Durante a Revolução, a razão alegada pelas mulheres para o seu envolvimento na luta política freqüentemente é a inação ou a covardia dos homens -elas os envergonham, declarando que eles não serão homens até conquistarem a liberdade. As mulheres então ameaçam tomar a frente e heroicamente defender a pátria com a própria vida: pegarão em armas se preciso for, e esse também é um tema constante na militância. Elas não se deixam enganar pelos "homens pérfidos" que tentam ludibriar os seus "irmãos" do Clube dos Cordeliers. Há um falso conformismo com a distância dos embates revolucionários: " relegadas em nosso retiro" a educação cívica dos filhos parece ser um pálido consolo pela "inabilidade" de contribuir à causa pública. A menção aos "hinos à liberdade" é significativa: elas sabiam separar o essencial do acessório. As cidadãs da Rue du Regard alertam seus "irmãos" (suposição de igualdade) dos perigos, e parecem almejar a plena participação, inclusive no combate, porém precisam justificar sua atitude com a incompetência masculina. A opinião de Kolly, relator da sessão, é reveladora do sentimento de muitos homens à época: "a manifestação tão vigorosa" das mulheres foge à natureza feminina; elas são portanto caracterizadas como "mulheres-homens", que se comportam como homens, embora sejam mães. E nessa situação embaraçosa, os homens ficam reduzidos a "homensmulheres", aos quais só resta o silêncio e a vergonha. Ecos de Rousseau. O temor da troca de papéis surge novamente, pois ela prenuncia o caos na sociedade, que começa com a humilhação masculina perante a mulher. A seguir, veremos o início da participação feminina nas jornadas revolucionárias.

\section{6 - A Bastilha}

No dia 14 de julho de 1789, a Bastilha foi tomada pela multidão, formada, em sua maioria, por pequenos artesãos do faubourg Saint-Antoine. Na lista dos vencedores, havia um nome de mulher, Marie Charpentier, esposa de Haucourt, lavadeira do Faubourg Saint-Marcel. Por decreto da Constituinte de 12 de dezembro de 1790, ela recebeu uma pensão de 200 libras como recompensa pelos ferimentos que sofreu na batalha. Marie-Françoise Williaume, misturada à multidão que tomou “a execrável Bastilha”, tinha as mãos enegrecidas pela pólvora do fuzil de que ela se 
apossara nos Inválidos ${ }^{129}$. Conta-se que uma moça de dezoito anos lutou disfarçada de homem ao lado do noivo. Marguerite Pinaigre, mulher de Bernard Vener, escreveu uma petição à Assembléia Nacional, reclamando a pensão prometida ao marido combatente, ferido no confronto: " não só este cidadão lutou na conquista da Bastilha com a maior coragem, mas sua mulher citoyenne, que subscreve a presente, trabalhou igualmente com todas as suas forças, e ambos resolveram triunfar ou morrer"130. De fato, essa mulher participou da luta, transportando no seu avental as garrafas utilizadas como buchas dos canhões apontados para a ponte levadiça da fortaleza. Um comerciante da Rue de Hurepoix relatou que "as mulheres e crianças pegavam as pedras do pavimento dos pátios, levavam para o alto das casas para atirá-las nos soldados"131.

São poucos os nomes registrados nos arquivos, mas suficientes para mostrar que as mulheres do povo estavam presentes desde os primeiros momentos da Revolução. Na verdade, as parisienses vinham acompanhando com vivo interesse os acontecimentos que se precipitavam desde a abertura dos Estados Gerais em 5 de maio de $1789^{132}$. Marand-Fouquet aponta o estabelecimento do caráter masculino do embate revolucionário, logo na primeira jornada em que o povo pegou em armas. De fato, houve poucas mulheres no ataque à Bastilha , muitas entre as vítimas, mas o que me chamou a atenção no relato é que as mulheres estavam ao lado de seus homens, enfrentando o perigo e ajudando na medida de suas possibilidades. Espectadoras ou participantes, começando nessa data emblemática, elas estiveram presentes em quase todos os levantes e jornadas revolucionárias. O detalhe curioso da moça disfarçada de soldado lutando junto com o noivo, se é que realmente existiu em 14 de julho, prenuncia o que acontecerá em maior escala na guerra, quando algumas realmente se alistarão vestidas de homem, junto com seus maridos ou amantes.

\footnotetext{
129 GODINEAU, Dominique, Citoyennes Tricoteuses - Les femmes du peuple à Paris pendant la Révolution Française, Paris, Editions Alinea, Perrin, 2004 , p. 109.

130 " Petição dirigida à Assembléia Nacional" - A.N., Fic III, Seine 71 - documento no. 4 IN LEVY, Darline G., APPLEWHITE, Harriet B., JOHNSON, Mary D. - Women in Revolutionary Paris 1789-1795 - . Selected documents translated with notes and commentary by the authors - Urbana e Chicago, University of Illinois Press, 1980.

${ }^{131}$ CAPON, Gaston, "La prise de la Bastille. Lettre inédite", Intermédiaire des chercheurs et des curieux LXXXVI, 1582 - (June, 1923) IN GARRIOCH, David, "The Everyday Lives of Parisian Women and the October Days of 1789" - Social History, Vol. 24, No. 3 (Oct., 1999) p. 244.

132 GODINEAU, Dominique, Citoyennes Tricoteuses - Les femmes du peuple à Paris pendant la
} Révolution Française, Paris, Editions Alinea, Perrin, 2004 , p. 109. 


\section{7 - A Marcha para Versalhes}

\subsection{1 - Antecedentes sociais e políticos}

A grande Marcha para Versalhes foi a primeira intervenção da multidão feminina na Revolução, e marcou o início da participação política expressiva das mulheres do povo no processo revolucionário. Independente de sua reação aos fatos, os contemporâneos não se espantaram com tal participação, pois estavam habituados à presença dessas mulheres no espaço público durante o Antigo Regime em Paris e Versalhes. Joan Landes acha que a Marcha para Versalhes se situa dentro de uma longa tradição de participação feminina em protestos populares, especialmente durante crises de subsistência. Nesta Marcha, contudo, havia uma nova "sensibilidade política" entre manifestantes de ambos os sexos ${ }^{133}$. David Garrioch também vê uma continuidade entre o modo de ação tradicional das mulheres do povo no século XVIII e os acontecimentos de outubro de 1789: o autor oferece exemplos anteriores à Revolução onde se percebe a iniciativa enérgica, a independência , e o exercício de poder comunitário por parte das mulheres ${ }^{134}$. As lojas e mercados de alimentos eram um território feminino por excelência. Tais mulheres tinham autoridade moral nas ruas: de suas barracas, as comerciantes observavam e controlavam em certa medida o que acontecia à sua volta, separando brigas entre homens ou mulheres, ou às vezes impedindo que pais se excedessem nos castigos físicos aos filhos. De acordo com o grande observador da vida parisiense, Louis-Sébastien Mercier, as vendedoras de peixe faziam a lei no mercado central - "les poissardes font la loi" ${ }^{135}$. Elas não hesitavam em enfrentar as autoridades e incitar rebeliões de vizinhos contra agentes de polícia ou das guildas que vinham ao seu bairro prender devedores, confiscar mercadorias, expulsar inquilinos inadimplentes. As mulheres intervinham no espaço público "feminino", pois estavam defendendo suas famílias e sua comunidade.

Responsáveis pelo orçamento doméstico e pela alimentação da família, eram elas que passavam horas nas filas das padarias, e portanto as que sofriam mais

\footnotetext{
${ }^{133}$ LANDES, Joan B., Women and the Public Sphere in the age of the French Revolution, Ithaca and London, Cornell University Press, 1988, pp. 109-10.

${ }^{134}$ GARRIOCH, David, "The Everyday Lives of Parisian Women and the October Days of 1789" Social History, Vol. 24, No. 3 (Oct., 1999) p. 231-249.

${ }^{135}$ MERCIER, Louis-Sébastien, Le Tableau de Paris, 12 vols, Amsterdam 1782-8, VI, p. 306 IN GARRIOCH, David, "The Everyday Lives of Parisian Women and the October Days of 1789" - Social History, Vol. 24, No. 3 (Oct., 1999) p. 241.
} 
agudamente a escassez e a carestia. As mulheres tomaram parte das revoltas populares em 1740-1 e das "guerras da farinha" em 1775. Já em 1720 , sabiam que o governo controlava de perto o mercado de cereais e que os protegidos dos ministros e da amante real estavam entre os maiores comerciantes. Assim, deduziam que havia conexão entre a alta de preços e a cobiça do círculo íntimo do governo. A subsistência era considerada preocupação legítima das mulheres. Seus companheiros e as autoridades aceitavam tacitamente o direito feminino de agir naquelas situações ${ }^{136}$. Michelet descreveu o desespero das mulheres no início da Revolução, e generalizou a atitude de algumas, contribuindo para disseminar no século seguinte o mito das “fúrias da guilhotina" sedentas de sangue:

As mulheres não se resignavam, elas tinham filhos .(grifo do autor) Elas vagavam como leoas. Em todos os levantes, eram as mais afoitas, as mais furiosas. Lançavam gritos frenéticos, envergonhavam os homens por sua lentidão; os julgamentos sumários da Grève eram sempre demorados demais para elas. Elas enforcavam primeiro ${ }^{137}$.

Alguns grupos de mulheres estabeleceram ligações diretas com o poder. As comerciantes do mercado (Dames de la Halle) e mais especificamente as vendedoras de peixe, tinham, desde o tempo da Fronda , o privilégio de acesso direto ao Rei: por ocasião do nascimento do Delfim, iam a Versalhes atestar a legitimidade do herdeiro do trono, e juntamente com outras corporações femininas eram convidadas para as festividades de aniversários e casamentos reais. Em tempos de seca e escassez, mandavam deputações ao Rei, assim como para celebrar vitórias e outras ocasiões especiais. Maria Leczinska, esposa de Luís XV, incentivou essa ligação, e sua reputação entre as mulheres do menu peuple ${ }^{138}$, cresceu na mesma proporção da impopularidade do marido mulherengo. Tornou-se uma das rainhas mais queridas da França ${ }^{139}$.

\footnotetext{
${ }^{136}$ GARRIOCH, David, "The Everyday Lives of Parisian Women and the October Days of 1789" Social History, Vol. 24, No. 3 (Oct., 1999) pp. 242-3.

${ }^{137}$ MICHELET, Jules, Histoire de la Révolution Française, Paris, Editions Robert Laffont, 1979, livre premier, pp. 171-172.

${ }^{138}$ Povo miúdo, arraia-miúda.

${ }^{139}$ HUFTON, Olwen H., Women and the Limits of Citizenship in the French Revolution, Toronto, Buffalo, London, University of Toronto Press, 1992, p. 15.
} 
A convocação dos Estados Gerais proporcionou outro canal de comunicação das mulheres com o poder. No "Cahier de Doléances" há exemplos de petições femininas dirigidas a esse corpo legislativo. No documento "Saudação das vendedoras de peixe aos seus irmãos do Terceiro Estado"140, percebe-se uma visão política surpreendentemente elaborada neste grupo de mulheres. Em 19 de maio, auge do conflito da verificação dos poderes dos deputados das Três Ordens nos Estados Gerais, "as vendedoras de laranjas e outras Dames de la Halle vieram cumprimentar a Assembléia e recomendar o interesse do povo aos deputados" . A homenagem pública aos deputados do Terceiro Estado foi um apoio de peso que não deve ter passado despercebido das outras ordens minoritárias e sem sustentação popular. Aquelas mulheres eram um termômetro do humor das ruas de Paris. Para terminar, como de costume, cantaram alguns versos em parte reproduzidos abaixo, e cuja autoria Hardy atribuiu ao poeta Maréchal:

Se o clero e a nobreza nos tratam com tanta rudeza, deixemos que eles percam o Estado; enquanto isso vamos beber ao Terceiro Estado"(...) " Será que eles se esqueceram que seu brilho e sua glória provêem do Terceiro Estado?"(...)"os Senhores que polidamente nos tratam como escória, terão que pagar a talha como nós, muito nobremente."(...) "O nascimento é obra do acaso. O primeiro que se fez Senhor foi um soldado; [depois se tornou] Rei; a quem deveu tal coisa? Ao Terceiro Estado.

Eis aí um panfleto político cantado, desafiando o status quo, no recinto da Assembléia, e em nome do povo. Apesar de serem leais ao Rei, as poissardes lembravam que ele devia sua posição ao Terceiro Estado, deixando no ar uma ameaça velada. Já havia começado a erosão da imagem e autoridade antes sacrossantas do Rei. Naturalmente, os deputados asseguraram à delegação feminina que se encarregariam de proteger seus interesses nos Estados Gerais. Coincidência ou não, nos dias 20 e 21 de maio, o clero e a nobreza renunciaram aos seus privilégios fiscais e aceitaram o princípio da igualdade de todos perante os impostos.

Vários aspectos me pareceram notáveis no comportamento do grupo neste episódio: a acuidade política das protagonistas que haviam compreendido o quanto estava em jogo na luta entre as Três Ordens; a consciência da importância do apoio popular aos legisladores e o sentido de oportunidade: elas vieram sustentar "seus

140 documento: "Compliment des dames poissardes a leurs frères du Tiers État" IN Les élections et les Cahiers de Paris en 1789 par Chassin - tome III-L'Assemblée des Trois Ordres et l'Assemblée Générale des électeurs au 14 juillet - Paris, 1889 - BNF -Bibliothèque Nationale de France. 
irmãos" no momento certo; a segurança de quem tem autoridade moral: elas vieram compenetradas de seu papel; a audácia de lembrar ao Rei, aos nobres e ao clero que deviam sua magnificência ao Terceiro Estado, o que também sinaliza a mudança da correlação de forças políticas no país. Por último, é relevante notar que, apesar da troca de amabilidades com os membros do Terceiro Estado, as visitantes não deixaram de dizer-lhes que "a voz pública" os tinha eleito para defender os interesses do povo. Ficou implícito que se não cumprissem sua missão, os mesmos eleitores poderiam revogar seus mandatos. Daí para a defesa do conceito de povo soberano e cidadania o caminho foi curto.

A Marcha para Versalhes não surgiu do nada. As antigas tradições estão na base da crescente conscientização política das mulheres do povo, da desenvoltura com que agiam perante as autoridades, e do estatuto moral de que se revestiam suas reivindicações revolucionárias. As militantes tinham uma bagagem política que lhes foi útil para encontrar novos modos de ação, adaptados às circunstâncias do momento.

\subsection{2 - Motivações da Marcha}

No dia 7 de agosto de 1789 uma deputação das Dames des Halles foi a Versalhes felicitar o rei e a Rainha pelo início dos trabalhos da Constituição que limitaria seus poderes. Michelet relata que elas se dirigiam ao Rei com muita familiaridade: “Pobre homem! estimado homem! bom papai!” e mais seriamente à Rainha: "Senhora, senhora, abra suas entranhas! vamos nos abrir ! não vamos esconder nada, vamos dizer bem francamente o que temos a dizer! "141. A linguagem não era de subserviência. Denotava afeto , mas também ligação com o poder. ${ }^{142}$ Gostar do Rei não impediu as comerciantes de aderir à Revolução. No dia 25 de agosto elas retornaram ao palácio para falar da escassez de pão em Paris, acompanhadas da Guarda Nacional. A diferença é que agora elas contavam com o apoio político do Prefeito Bailly e com a aliança da recém-formada Guarda Nacional, o que deu às

\footnotetext{
${ }^{141}$ MICHELET, Jules, Les Femmes de la Révolution - 1853 - apresentado por Françoise Giroud, Carrère, 1988, p. 72.

${ }^{142}$ APPLEWHITE, Harriet B. \& LEVY Darline G. "Responses to the Political Activism of Women of the People in Revolutionary Paris, 1789-1793”. IN Women and the Structure of Society - Selected research from the fifth Berkshire Conference on the History of Women., edited by Barbara J. Harris and JoAnn K. McNamara. Duke Press Policy Studies, 1984, p. 218.
} 
reivindicações o suporte de uma força militar. Em Versalhes, temia-se que tais visitas ao Rei aumentassem a mobilização popular. Georges Rudé viu nessas demonstrações dos faubourgs e do menu peuple em agosto e setembro um "tira-gosto" da Marcha para Versalhes ${ }^{143}$. Em Paris, falava-se outra vez de um suposto complô dos aristocratas que queriam derrotar o povo pela fome. Para as mulheres do povo, era o pior dos mundos: a escassez, os altos preços dos alimentos e o desemprego causado pela retração do comércio da moda e da criadagem doméstica, afetados seriamente pela crescente emigração dos nobres. Nessa situação, as mulheres começaram a agir de formas não tradicionais ${ }^{144}$, saindo em procissões e marchas rituais quase diárias. Em 14 de setembro, houve uma marcha de ação de graças a Santa Genoveva da qual participaram setecentas moças e mulheres, seus companheiros operários de diferentes distritos, membros da Guarda Nacional, trombeteiros, todos armados, levando com eles um modelo da Bastilha em madeira. O livreiro Siméon-Prosper Hardy ${ }^{145}$ ficou apreensivo com as proporções do cortejo e relatou que muitas pessoas julgaram haver algo de assustador na organização e magnitude do cortejo e suspeitavam que a piedade não seria o único motivo dos devotos da padroeira de Paris. Realmente, as armas e o símbolo da vitória do povo sobre a tirania, a Bastilha, não faziam parte das tradições religiosas.

Prudhomme interpretou o evento como uma celebração da derrota do despotismo, mas os dois homens ficaram impressionados com a coordenação dos diferentes grupos. Entre os integrantes, havia meninas e mulheres que rezavam para a Virgem, conquistadores da Bastilha, operários do faubourg, devedores libertados e a Guarda Nacional armada - todos carregando símbolos de fome e colheita, despotismo derrotado, e do poder armado da cidadania livre Essas mulheres estavam ligando a

\footnotetext{
${ }^{143}$ RUDE, George, The Crowd in the French Revolution , London, Oxford University Press Oxford at the Clarendon Press, 1959, pp. 66-7.

${ }^{144}$ LEVY, Darline G., APPLEWHITE, Harriet B., JOHNSON, Mary D. - Women in Revolutionary Paris - 1789-1795 - . Selected documents translated with notes and commentary by the authors Urbana e Chicago, University of Illinois Press, 1980, pp. 14-15.

${ }^{145}$ Siméon-Prosper Hardy, Mês Loisirs, vol. VIII, fols. 431,443,479 in BNF, Mss.fr.,vol 6687 IN LEVY, Darline G., APPLEWHITE, Harriet B., JOHNSON, Mary D. - Women in Revolutionary Paris 1789-1795 - . Selected documents translated with notes and commentary by the authors - Urbana e Chicago, University of Illinois Press, 1980, pp. 34-35.
} 
tradição dos festivais religiosos com questões prementes de subsistência e política ${ }^{146}$. Hardy tinha razão, o barril de pólvora estava prestes a explodir.

No dia 5 de outubro de 1789, a continuada falta de pão e as notícias de ofensas à cocarda $^{147}$ nacional por parte dos oficiais do Regimento de Flandres num banquete em Versalhes foram o estopim de uma insurreição. Sete mil mulheres do menu peuple vindas dos distritos e faubourgs de Paris se reuniram no Hotel de Ville, denunciaram Bailly e Lafayette por incúria administrativa, e, ajudadas por homens munidos de piques, tridentes e lanças, derrubaram as portas das salas de armamentos e tomaram as armas que encontraram. Lafayette hesitou em apoiar um protesto dessa magnitude, mas os membros radicais da Guarda Nacional ofereceram sua proteção armada às mulheres. Em seguida, sob a liderança de Maillard, um vencedor da Bastilha, marcharam rumo a Versalhes para interpelar a Assembléia Nacional e pedir ajuda ao árbitro supremo, o Rei. Tinham a intenção de trazê-lo de volta a Paris, onde a influência "maléfica" da Rainha e da corte seriam menores: iriam ao palácio buscar "o padeiro, a padeira e o padeirinho" ${ }^{148}$. Elas acreditavam que a presença do Rei teria o condão de acabar com a falta de pão. $\quad$ A crise era de subsistência mas também política. Enquanto se debatia o conceito de soberania popular nas esquinas de Paris, o Rei se recusava a sancionar os decretos de 4 de agosto que acabavam com os privilégios da nobreza, e a Declaração dos Direitos do Homem e do Cidadão, aprovada pela Assembléia Nacional em 26 de agosto.

Alguns dias antes da invasão do Hotel de Ville, mulheres amotinadas tinham se queixado : "os homens ficam para trás... os homens são covardes... amanhã as coisas funcionarão melhor: nós vamos comandar as negociações" ${ }^{149}$. Segundo Maillard, naquele dia 5 de outubro algumas queriam queimar os papéis que encontraram nas salas do Hotel de Ville, dizendo " é só isso o que o conselho da cidade tem feito" e segundo

\footnotetext{
${ }^{146}$ APPLEWHITE, Harriet B. \& LEVY Darline G. "Responses to the Political Activism of Women of the People in Revolutionary Paris, 1789-1793. IN Women and the Structure of Society - Selected research from the fifth Berkshire Conference on the History of Women., edited by Barbara J. Harris and JoAnn K. McNamara. Duke Press Policy Studies, 1984, pp. 218- 220.

${ }_{147}^{147}$ A cocarda ou roseta tricolor se tornou um símbolo nacional desde o 14 de julho de 1789.

${ }^{148}$ MARAND-FOUQUET, Catherine, La femme au temps de La Révolution - 1989, Éditions Stock/Laurence Pernoud, p. 72 e 80.

149 citação: " les hommes traînent...les hommes sont des lâches... Demain les choses iront mieux: nous nous mettrons à la tête des affaires" IN HUFTON, Olwen H., Women and the Limits of Citizenship in the French Revolution, Toronto, Buffalo, London, University of Toronto Press, 1992, p. 13.
} 
um observador: "os homens não tinham força suficiente (...) as mulheres mostrariam que eram melhores que os homens"150. Tais comentários denotam uma impaciência feminina com a inação masculina, e com a papelada administrativa que não resolvia a falta de gêneros. Dali saíram vários grupos para recrutar outras mulheres, as quais vieram em massa de todas as direções para o ponto de encontro no meio dos Champs Elysées. Armadas de lanças, foices, machados, mosquetões, puxando um canhão sem munição, marcharam quatorze quilômetros em seis horas sob a chuva. O chefe do cortejo, Maillard, relata que usou sua autoridade várias vezes para impedir violências das manifestantes contra pessoas e propriedades no caminho ${ }^{151}$. As mulheres foram recebidas em Versalhes por gritos de "Viva nossas parisienses!", ao que elas responderam "Viva Henrique IV!" O grupo armado se precipitou sobre a Assembléia Nacional, onde Maillard apresentou a petição das mulheres, e citou um panfleto popular "Quando teremos pão?", no qual as autoridades e não os padeiros eram responsabilizados pela escassez ${ }^{152}$. As manifestantes ocuparam galerias , interromperam debates, pressionaram e intimidaram os deputados : “quem está falando aí? Calem a boca desse tagarela. Não se trata disso . Trata-se de ter pão (...)”153, gritou uma vendedora de peixe. Uma mulher ocupou a cadeira de Mounier, o Presidente da Assembléia, temporariamente ausente da sala, e todas "votaram" moções e leis sobre a circulação e distribuição de cereais. Mounier foi repreendido pelo seu apoio ao "veto perverso"154 (le vilain véto), que foi a tentativa de conceder ao Rei o direito de veto absoluto sobre a legislação aprovada pela Assembléia. Em seguida, as

150 LEVY, Darline G. e APPLEWHITE Harriet B. "Women and Militant citizenship in Revolutionary Paris” IN MELZER, Sara E. And RABINE, Leslie W. (editoras), Rebel Daughters -Women and the French Revolution, New York - Oxford, Oxford University Press, 1992, p. 83.

151 Depoimento de Stanislas Maillard, herói da Bastilha e membro da Guarda Nacional, no qual descreve a marcha das mulheres para Versalhes em 5 e 6 de outubro de 1789. Fonte: Procédure criminelle instruite au Châtelet de Paris, 2 vols (Paris, 1790), vol.I, pp. 117-32, reprinted from George Rudé, Ed. The Eighteenth Century (New York, 1965), pp. 198-205. ${ }^{151}$

152 RUDE, George, The Crowd in the French Revolution , London, Oxford University Press Oxford at the Clarendon Press, p. 75-6.

153 MARAND-FOUQUET, Catherine, La femme au temps de La Révolution - 1989, Éditions Stock/Laurence Pernoud, p. 75.

${ }^{154}$ Em setembro de 1789 a questão do veto real dividia os deputados entre os que queriam conceder ao Rei o poder de veto absoluto à legislação aprovada pela Assembléia: Mounier, Mirabeau,LallyTolendal , Malouet e Clermont-Tonerre, junto com os nobres liberais, religiosos, burgueses com poderes senhoriais desejavam o fim da Revolução e a reconciliação com o monarca, e os deputados que propunham um veto apenas suspensivo: Du Port, Barnave e Lameth, que assumiram a direção do partido patriota, e foram vitoriosos. O veto suspensivo foi concedido ao Rei em 11 de setembro, com a condição tácita de que o monarca aprovasse os decretos de agosto - IN LEFEBVRE, Georges,

LEFEBVRE, Georges - La Révolution Française - Presses Universitaires de France, Paris, 1989, p. 128. 
insurgentes declamaram versos e caçoaram dos deputados. Para Levy e Applewhite , o comportamento das mulheres tinha elementos de farsa e dos antigos charivaris populares, com sua característica subversão hierárquica ${ }^{155}$. Porém , o clima não era de carnaval: as manifestantes estavam armadas, deixaram claro que falavam sério e não iam se deixar enganar com falsas promessas, mostrando seu braço levantado. Uma deputação de 12 mulheres foi ao palácio junto com o Presidente da Assembléia, Mounier, pedir providências ao Rei sobre a escassez de trigo, e obteve do monarca a promessa do pronto abastecimento de Paris. Mas as delegadas não trouxeram o compromisso por escrito, e foram severamente criticadas pelas outras ${ }^{156}$. A palavra de Luis XVI já não valia grande coisa. A crise de subsistência se confundiu com a da legitimidade política. A dramaturgia de 5 de outubro pode ser lida como uma tomada simbólica de poder por parte das mulheres enquanto membros da soberania popular ${ }^{157}$.

O palácio foi invadido na madrugada do dia seis, e a Rainha escapou por pouco da fúria popular. Dois guardas foram assassinados e decapitados, talvez por um modelo da Academia de nome Nicolas, de acordo com o depoimento de uma das participantes da marcha, Madelaine Glain ${ }^{158}$. Nada indica que alguma delas tenha participado do massacre dos guardas reais. Ao saber que Lafayette estava se dirigindo a Versalhes à frente de mil e duzentos soldados, o Rei assinou os decretos de agosto. As mulheres estavam exaustas, famintas, mas vitoriosas: o Rei prometeu fazer o que estivesse ao seu alcance para restabelecer o suprimento de pão em Paris, e concordou em voltar a viver em Paris com sua família, onde ficaria próximo da vigilância popular. De fato, veio pela estrada escoltado pelo povo e pela Guarda Nacional .

\footnotetext{
${ }^{155}$ APPLEWHITE, Harriet B. \& LEVY Darline G. "Responses to the Political Activism of Women of the People in Revolutionary Paris, 1789-1793. IN Women and the Structure of Society - Selected research from the fifth Berkshire Conference on the History of Women., edited by Barbara J. Harris and JoAnn K. McNamara. Duke Press Policy Studies, 1984. p. 223.

${ }^{156}$ HUFTON, Olwen H., Women and the Limits of Citizenship in the French Revolution, Toronto, Buffalo, London, University of Toronto Press, 1992, p. 10.

${ }^{157}$ LEVY, Darline Gay e APPLEWHITE, Harriet B. - "Women and Militant Citizenship in Revolutionary Paris” I N MELZER, Sara e RABINE, Leslie W. (editoras), Rebel Daughters -Women and the French Revolution, New York - Oxford, Oxford University Press, 1992, pp.84-5

${ }^{158}$ Depoimento no. LXXXIII - Procédure criminelle instruite au Châtelet de Paris (Paris, 1790) documento no. 9 IN LEVY, Darline G., APPLEWHITE, Harriet B., JOHNSON, Mary D. - Women in Revolutionary Paris - 1789-1795 - . Selected documents translated with notes and commentary by the authors - Urbana e Chicago, University of Illinois Press, 1980, p. 47.
} 


\subsubsection{Repercussões da marcha}

O acontecimento gerou alguns mitos acerca das "mulheres de outubro", como ficaram conhecidas na época e na historiografia. Os contemporâneos conservadores e moderados consideraram aquelas mulheres "fúrias incontroláveis" e prostitutas a soldo do Duque de Orléans que queria tomar o lugar de Luis XVI como monarca constitucional ${ }^{159}$. Para eles, o levante era uma amostra do que aconteceria se não se reprimisse a explosão da vontade popular. Madame Roland também duvidou da espontaneidade da Marcha: “alguém deve ter pago essas mulheres imbecis e grosseiras ... para representarem uma comédia sem graça”"160 . Roland desqualifica a capacidade e independência política de seu sexo. A historiadora Marand-Fouquet ${ }^{161}$ também sugere que a idéia da Marcha não surgiu espontaneamente entre as mulheres algumas das quais foram obrigadas a aderir. Pelo contrário, já estaria no ar desde o mês de agosto: políticos como Dussaulx, Desmoulins e Danton propunham uma manifestação em Versalhes para trazer o Rei de volta a Paris. Uma vez na capital, centro nervoso da vida política, econômica e cultural do país, sob vigilância cerrada do povo e da imprensa, seria mais fácil impedir o veto real aos textos constitucionais. Esperava-se que o monarca se reaproximasse dos súditos, como fez seu antepassado Henrique IV. No Palais Royal e no Café du Foy houve mesmo uma tentativa de lançar a Marcha, mas o povo não seguiu, o que aponta para a importância da iniciativa das mulheres, mesmo que a idéia não tenha surgido entre elas.

O conservador inglês Edmond Burke, ferrenho adversário da Revolução, descreveu a volta da família real para Paris: " Os cativos reais seguiram lentamente o cortejo, em meio a gritos lancinantes, danças frenéticas, impropérios afrontosos, e abominações indizíveis das fúrias do inferno na forma insolente das mais vis mulheres"162. Logo no início da Revolução, Burke foi pioneiro no uso de imagens de

\footnotetext{
${ }^{159}$ LEVY, Darline G., APPLEWHITE, Harriet B., JOHNSON, Mary D. - Women in Revolutionary

Paris - 1789-1795 - . Selected documents translated with notes and commentary by the authors Urbana e Chicago, University of Illinois Press, 1980, p. 16-17.

160 idem.

${ }^{161}$ MARAND-FOUQUET, Catherine, La femme au temps de La Révolution - Paris, Éditions Stock/Laurence Pernoud, 1989, p. 72-80.

162 Ambas as citações IN LANDES, Joan B., Women and the Public Sphere in the age of the French Revolution, Ithaca and London, Cornell University Press, 1988, p. 112.
} 
bruxaria para caracterizar as mulheres engajadas na política. Mary Wollstonecraft , simpática às participantes da Marcha em sua primeira obra sobre a Revolução, responde a Burke que ele" provavelmente se referia a mulheres que ganhavam a vida vendendo verduras ou peixe e nunca tinham desfrutado dos benefícios da educação". Quatro anos depois, entretanto, desiludida com a mobilização popular e o Terror, Wollstonecraft concordava com a tese das "mulheres da sarjeta" sem espírito público, pagas com o ouro do Duque de Orléans, agindo sob instigação de mentores do complôn ${ }^{163}$. O relato de Sébastien Mercier sobre a volta da multidão de Versalhes foi igualmente uma condenação moral:

duzentos mil homens na estrada, dançando (...) cada um com uma prostituta nos braços; as vendedoras de peixe sentadas nos canhões, outras usando barretes frígios, barris de vinho junto das caixas de pólvora, (...) o barulho, a imagem da antiga Saturnalia, nada poderia descrever o comboio que trouxe de volta o monarca (...) ${ }^{164}$ (grifo meu).

Nesses depoimentos conservadores notamos repetidos ataques à moral pessoal das protagonistas da Marcha. Já se delineia a intenção de associar o engajamento político à falta de virtude nas mulheres, pois a desenvoltura na cena pública nacional fugia às normas de comportamento feminino da época. A esfera pública era terreno masculino.

Os observadores contemporâneos radicais, ao contrário, criaram uma "lenda dourada" sobre as "heroínas de Versalhes". A jornalista Louise de Kéraglio foi uma das que contribuiu para mitologização das jornadas de outubro, elogiando a coragem das manifestantes em seu artigo de 8 de outubro de 1789. Interessante notar que ela também reconheceu que aquelas mulheres tinham ultrapassado os limites aceitáveis para seu sexo, porém justificou os excessos pela escassez de pão. Outros jornalistas eram ambivalentes: se por um lado celebravam a vitória das parisienses, por outro afligiam-se com o perigo do povo rebelado e fora de controle. Talvez por isso mesmo tenham contribuído para transformar as mulheres em símbolos de inspiração, criando um espaço idealizado e delimitado para elas. Exemplo dessa intenção foi a cunhagem de uma medalha mostrando a família real retornando a Paris liderada pela

\footnotetext{
${ }^{163}$ LANDES, Joan B., Women and the Public Sphere in the age of the French Revolution, Ithaca and London, Cornell University Press, 1988 , pp. 149-50.

${ }^{164}$ GUTWIRTH, Madelyn, The Twilight of the Goddesses - Women and Representation in the

French Revolutionary Era - New Jersey, Rutgers University Press, 1992 , p. 243.
} 
deusa da Liberdade ${ }^{165}$. As mulheres de carne e osso foram assimiladas às criaturas míticas da antiguidade pagã, principalmente no período republicano da Revolução, quando passaram a representar alegoricamente as virtudes cívicas.

Loustalot descreveu em seu jornal Révolutions de Paris alguns detalhes da marcha que permaneceram no imaginário social: " algumas conduzem os cavalos, outras, sentadas sobre os canhões levam na mão a temível mecha e outros instrumentos de morte (...)" ${ }^{166}$ (grifo meu). Outros jornalistas liberais analisaram o acontecimento, sendo que dois deles anônimos, os quais cito a seguir. O primeiro escreveu o panfleto As Heroínas de Paris, ou a Inteira Liberdade da França, pelas Mulheres - Polícia que elas devem exercer de sua própria autoridade. Expulsão dos Charlatães ${ }^{167}$. O

autor quis integrar a marcha de outubro na mitologia revolucionária:

(..) nossa liberdade está fortalecida (...) e foram as mulheres que a restauraram para nós! E com que glória imortal elas se cobriram. E com que ordem e coragem quase dez mil foram pedir satisfações aos amigos do despotismo (...) pelo crime de lesa-nação cometido a sanguefrio [o insulto à cocarda nacional]. Ela [a Providência] inspirou as mulheres com a resolução de libertar a Pátria, e fez com que vencessem. (...) Os aristocratas dizem que essas mulheres vão comemorar sua vitória no cabaré. (...) Esta crítica é séria e precisa ser respondida. As mulheres que celebramos são desordeiras sem sentimentos heróicos de honra? Respondo que por trás de sua aparência desvantajosa as mulheres do povo têm um sólido caráter (...)" Nota do autor: há pessoas que querem manter o povo ignorante por medo que aprendam o valor da liberdade (...)

O jornalista acha que elas merecem toda a gratidão, e para retribuir o grande feito, dá alguns conselhos às heroínas, o que denota seu nervosismo com sua atuação:

elas não devem mais iniciar passeatas que as degradem; devem se mostrar à altura da glória que adquiriram perante toda a França; devem adotar uma auto-disciplina que as honrará; nunca beber em excesso (as mulheres devem ser a encarnação da suavidade e da modéstia) nem permitir a embriaguez nos homens; não ficar se distraindo com charlatães; mostrar respeito pelo clero e pessoas com títulos; fiscalizar a qualidade dos alimentos que entram em Paris; (...) .

\footnotetext{
${ }^{165}$ APPLEWHITE, Harriet B. \& LEVY Darline G. "Responses to the Political Activism of Women of the People in Revolutionary Paris, 1789-1793. IN Women and the Structure of Society - Selected research from the fifth Berkshire Conference on the History of Women., edited by Barbara J. Harris and JoAnn K. McNamara. Duke Press Policy Studies, 1984, p. 222.

${ }^{166}$ citação IN DUHET, Paule-Marie, Les femmes et la Révolution 1789-1794, Paris, Gallimard/Julliard, 1971, p. 48.

${ }^{167}$ Documento "Par un homme de lettres connu, qui va publier un ouvrage intitulé La France vue dans l'avenir'. Les Héroïnes de Paris, ou L'Entière liberté de la France par des Femmes. Police qu'elles doivent exercer de leur propre autorité. Expulsion des Charlatans, etc.etc., le 5 octobre 1789 [n.p., n.d] in B.N. Lb39 2411. IN LEVY, Darline G., APPLEWHITE, Harriet B., JOHNSON, Mary D. - Women in Revolutionary Paris - 1789-1795 - . Selected documents translated with notes and commentary by the authors - Urbana e Chicago, University of Illinois Press, 1980, doc. 10.
} 
O jornalista queria o fim dessas marchas de protesto, agora que as mulheres já tinham alcançado seus objetivos. Os elogios e recomendações mostravam que desejava enquadrá-las nos limites da discrição e moderação apropriados para as mulheres da burguesia. Podiam, entretanto, ser úteis naquele papel feminino tradicional de fiscalização dos alimentos, ligado à saúde das famílias e da comunidade.

O segundo jornalista escreveu um artigo no jornal Révolutions de Versailles et de Paris analisando as jornadas de 5 e 6 de outubro, e dedicou o número às damas francesas ${ }^{168}$. Ele relata os acontecimentos e se refere às mulheres como

Oh, generosas heroínas! É às senhoras que os franceses devem esta segunda revolução, a qual decidirá a sorte gloriosa reservada aos seus elevados destinos! (...) grita-se que é preciso ir a Versalhes. As mulheres são as primeiras a fomentar a insurreição: elas se juntam (elles s"attroupent) , e obrigam todas as que encontram pelo caminho (..) a cozinheira, a devota que ia à igreja, a modesta costureira, a elegante modista, a mulher de chapéu e a de touca, todas são iguais nesta nova milícia(..) elas tomam o caminho de Versalhes armadas de piques e foices, seguidas pelos habitantes do faubourg Saint-Antoine, uma multidão de operários.(...)Burgueses e cidadãos de todas as classes, armados ou não, entram no cortejo.

A Guarda Nacional acompanhou a marcha. Quanto ao objetivo do movimento "diz-se que no momento da partida as mulheres juraram arrancar o Rei dos braços dos aristocratas para que ele viesse morar no meio de seu povo(...)" $\mathrm{Na}$ Assembléia Nacional, elas "votaram" resoluções sobre o abastecimento de Paris, e segundo o autor: " exerceram portanto, naquela incomparável jornada, as funções do poder legislativo e do poder executivo". A votação foi simbólica, pois no dia seguinte os deputados anularam todas as resoluções da véspera, tomadas sob pressão. Durante as discussões sobre o preço do pão, o Bispo de Langres quis oferecer dinheiro às damas carentes, mas "uma recusa unânime ressoou pela Sala, e as Damas acrescentaram generosamente que se havia dinheiro para dar, devia ser colocado na Caixa patriótica". Na madrugada do dia 6, após a Guarda Real ter atirado nas mulheres, a "Guarda burguesa de Versalhes, os Dragões, o Regimento de Flandres, indignados com a conduta da Guarda do Rei, se reuniram às nossas bravas Cidadãs". A bravura de quem se sente imbuído de uma missão fazia adeptos até entre os militares - tanto entusiasmo podia ser perigoso. As mulheres começam a praticar a cidadania e são chamadas de cidadãs.

168 Documento Révolutions de Versailles et de Paris, dédiées aux dames françoises - No. I, outubro de 1789 - autor anônimo IN LUCAS, Colin, Editor-in-Chief The French Revolution Research Collection, University of Chicago, 1992 , The New York Public Library - microficha no. 9.4/13. 
Este testemunho é enfático quanto à iniciativa feminina e seus objetivos tanto políticos como de subsistência; exalta a importância da insurreição, a qual levará os franceses a grandes destinos. De fato, a chegada do Rei e da Assembléia Nacional em Paris mudou o curso da Revolução; percebemos que a composição da Marcha era variada, incluindo militares, operários, membros da burguesia, homens e mulheres; apesar de algumas mulheres terem sido coagidas a acompanhar, a maioria parece ter vindo por livre e espontânea vontade, assim como os burgueses e outros. O documento deixa transparecer a consciência do momento histórico e um sentimento patriótico compartilhado pelos manifestantes, mas inicialmente inspirados pelas mulheres. A determinação das participantes contagiou até membros do Regimento de Flandres, antes acusados de insultar a cocarda nacional. Na Assembléia Nacional, elas souberam demonstrar seu espírito público, recusando o oferecimento pecuniário do Bispo e exigindo respeito às necessidades do povo. Entretanto, fizeram-no desafiando as autoridades e invertendo os papéis dos gêneros aceitos na época, o que causou repúdio entre a maioria dos constituintes ali reunidos.

O jornalista anônimo emprestou um imenso significado político às ações femininas, ao dizer que as mulheres "exerceram o poder legislativo e executivo". Applewhite considera a afirmação exagerada, ponderando que em outubro de 1789, elas ainda não tinham a consciência política sofisticada e a organização institucional influente que viriam a ter somente em $1793^{169}$. É verdade, porém acho que as francesas forjaram sua cidadania de facto desde o início da Revolução, e principalmente a partir das jornadas de outubro. A documentação da época é muito significativa a esse respeito e mostra um grau de compreensão política além do que se poderia esperar de pessoas com pouca educação formal e contato com instâncias de poder. Um exemplo é a crítica das manifestantes ao apoio de Mounier, Presidente da Assembléia, ao poder de veto do Rei sobre os decretos do legislativo. Talvez elas não tivessem compreendido todos os meandros da questão, mas sabiam que não interessava ao povo - nem aos seus representantes- conceder ao Rei tal poder de veto. O cataclisma da Revolução abriu espaços inéditos de participação política a pessoas que

\footnotetext{
${ }^{169}$ APPLEWHITE, Harriet B. \& LEVY Darline G. "Responses to the Political Activism of Women of the People in Revolutionary Paris, 1789-1793. IN Women and the Structure of Society - Selected research from the fifth Berkshire Conference on the History of Women., edited by Barbara J. Harris and JoAnn K. McNamara. Duke Press Policy Studies, 1984, p. 224.
} 
antes estavam à margem da vida pública, preparadas do que se pensava para ocupá-los.

e as mulheres do povo estavam mais Penso que isso explica a preocupação das testemunhas aqui citadas em conter a ação feminina e popular dentro de certos limites. Apreensivos com o levante, autoridades como Lafayette, Bailly e a corte usaram sua influência para desacreditar as jornadas revolucionárias ${ }^{170}$. Sinal da importância do levante de 5 e 6 de outubro!

Michelet também valorizou as participantes da Marcha para Versailles. Para ele "a revolução de 6 de outubro, necessária, natural e legítima (...) toda espontânea, imprevista, verdadeiramente popular, pertence sobretudo às mulheres, como a de 14 de julho aos homens. Os homens tomaram a Bastilha, as mulheres tomaram o Rei"171.

Já Georges Lefebvre parece concordar com a tese da orquestração da marcha: "no dia 5, as mulheres do Faubourg Saint-Antoine e dos Halles se reuniram no Hotel de Ville para exigir pão: não podia ser um acaso, mas nós não sabemos nada dos preparativos” $^{172}$ (grifo meu). Dominique Godineau não tem dúvidas sobre a iniciativa feminina do movimento, o qual, uma vez lançado, obteve a adesão de homens organizados em corpos armados. Essa dinâmica relacional se repetiu em outras jornadas revolucionárias, notadamente na revolta de Prairial em 1795. Quanto à motivação das mulheres, Godineau acha que "Numa situação política de enfrentamento, a questão do pão serve para mobilizar as mulheres e está na origem da formação da multidão feminina(...)". $\quad$ Não obstante, a fome não as tornava insensíveis ao ambiente político: quando um monarquista lhes sugeriu que haveria pão se o Rei recuperasse toda sua autoridade, mulheres o insultaram, dizendo que " queriam pão, mas não ao preço da liberdade”, isto é, não ao preço da obediência ao Rei ${ }^{173}$. As preocupações de subsistência vinham acompanhadas de sentimentos cívicos.

\footnotetext{
${ }^{170}$ MARAND-FOUQUET, Catherine, La femme au temps de La Révolution - 1989, Éditions Stock/Laurence Pernoud, p. 96.

${ }^{171}$ MICHELET, Jules, Histoire de la Révolution Française, Paris, Editions Robert Laffont, 1979, livre premier, pp.244-246.

172 LEFEBVRE, Georges - La Révolution Française - Presses Universitaires de France, Paris, 1989, p. 130.

173 GODINEAU, Dominique, Citoyennes Tricoteuses - Les femmes du peuple à Paris pendant la
} Révolution Française, Paris, Editions Alinea, Perrin, 2004 , p. 110-111. 
E o que pensaram as próprias mulheres a respeito da Marcha para Versalhes? Alguém compôs uma "Canção das Poissardes" (vendedoras de peixe):

Arrastamos nosso canhão até Versalhes; éramos apenas mulheres mas queríamos mostrar coragem irreprimível; fizemos os homens de espírito perceberem que nós, assim como eles, não tínhamos medo; com nossas armas, nos lançamos como Amadis da Gália; como guerreiras, ganhamos os lauréis e a glória, e despertamos esperança de glória para a França. ${ }^{174}$.

Essas mulheres sonhavam com a glória, a própria e a da França, conquistada com coragem, prenunciando seu futuro engajamento militar. Uma nota publicada na revista feminina Les Etrennes Nationales des Dames dizia:

"No último dia 5 de outubro as parisienses provaram aos homens que são tão corajosas e empreendedoras quanto eles...sofremos mais que os homens, que com suas declarações de direitos nos deixam em estado de inferioridade, e até de escravidão (...)Se há maridos aristocráticos o bastante em seus lares para se opor ao compartilhamento das honras patrióticas, usaremos as armas (...) contra eles".

Eis aí uma exigência ousada de igualdade absoluta. A autora sabia que os homens faziam uma interpretação excludente da Declaração dos direitos... e se rebelava contra o alijamento das mulheres - elas queriam "fazer parte", e participar das honras patrióticas, das quais sua coragem as tornava merecedoras. Mas a ameaça de usar armas contra os homens ultrapassava os limites da razoabilidade, e soava como uma intolerável inversão de papéis.

\section{Surgiu também um panfleto Reivindicação das damas à Assembléia} Nacional, que com base nos direitos universais contidos na Declaração dos direitos do homem e do cidadão, e na "coragem marcial" que as mulheres tinham demonstrado nas jornadas revolucionárias do verão e outono de 1789, exigia direitos e poderes iguais para as mulheres serem também legisladoras, magistradas, eclesiásticas e militares $^{175}$. Mais uma vez a coragem na Marcha e a Declaração são a justificativa da reivindicação de honras e igualdade. A Declaração foi criada pelos deputados constituintes, mas a "coragem marcial" foi exercida na prática pelas manifestantes de outubro, por isso acho que é tão valorizada nessas declarações. Junto com seus

\footnotetext{
174 ambas as citações IN GUTWIRTH, Madelyn, The Twilight of the Goddesses - Women and Representation in the French Revolutionary Era - New Jersey, Rutgers University Press, 1992 , pp. 244-5.

${ }^{175}$ LEVY, Darline G. e APPLEWHITE Harriet B. "Women and Militant citizenship in Revolutionary Paris” IN MELZER, Sara E. And RABINE, Leslie W. (editoras), Rebel Daughters -Women and the French Revolution, New York - Oxford, Oxford University Press, 1992,p. 85.
} 
companheiros homens, e mulheres de outras classes sociais, as militantes tinham arriscado a vida na insurreição, e algumas saíram feridas. A experiência das jornadas revolucionárias de outubro despertou nas mulheres um sentimento de pertencimento ao "povo soberano".

Há também o depoimento de Sra. Cheret "que teve a honra de fazer parte da deputação na Assembléia Geral" ${ }^{176}$. Essa testemunha relata que resolveu deixar sua loja para se juntar às damas cidadãs que "voaram a Versalhes" sob o comando de Maillard e outros voluntários da Bastilha, "os quais quiseram informar a Assembléia Nacional sobre a origem da infelicidade do povo, sem o qual os maiores monarcas não podem absolutamente nada". A Assembléia Nacional lhes pareceu muito imponente, porém nem o ambiente, nem a presença de nobres e eclesiásticos as inibiu. Ao contrário, Cheret considerou que os nobres usufruíam de bens concedidos pela credulidade cega dos antepassados, e não representavam a nação. A determinação das damas convenceu os deputados a atender os seus pedidos quanto à circulação de cereais, taxas sobre o trigo e preço da carne. O grupo tinha objetivos claros, que foram todos cumpridos. O Rei cedeu e concordou em voltar a Paris, e assim cresceu outra vez na estima popular. Segundo Cheret, Luís XVI mostrou que merecia o epíteto de Restaurador da Nação Francesa e "nossas Cidadãs, cobertas de glória, foram reconduzidas em charretes, às custas de Sua Majestade, ao Hotel de Ville de Paris, onde nós as recebemos como libertadoras da Capital". A Sra. Cheret compreendia que nenhum monarca pode governar sem o apoio do povo, do qual as mulheres são parte integrante. A ligação entre as jornadas de outubro e os direitos da soberania popular não se fez esperar. As mulheres - chamadas de cidadãs - entraram em Paris como "libertadoras da Capital". Não é pouco: é costume festejar soldados vitoriosos dessa forma. Heróis vencedores merecem prêmios, ou melhor, conquistam direitos.

Há uma grande distância entre a auto- percepção exaltada das militantes e de alguns homens que as apoiaram, e a visão que acabou predominando na sociedade: as mulheres de outubro eram perigosas, descontroladas, violentas, queriam subverter a hierarquia social e as relações entre os sexos. O horror à inversão de papéis teria vida

\footnotetext{
${ }^{176}$ Documento " Evenément de Paris et de Versailles" - outubro 1789 IN Cahiers de doléances des femmes en 1789 et autres textes - préfacé par Paule-Marie Duhet - Paris, C. Des femmes 1981, p. 79-82.
} 
longa na Revolução. As militantes tinham que ser refreadas, e essa preocupação influenciou as decisões relativas aos direitos políticos de todas as mulheres. As conseqüências das diferentes percepções sobre a Marcha de Versailles foram dramáticas e duradouras.

O que era novo? As mulheres fizeram a transição da política local dos seus bairros para a cena nacional ao se dirigirem aos centros de poder: a Prefeitura de Paris, a Assembléia Nacional e o Rei ; a escala da manifestação e a ambição dos objetivos; a união das antigas tradições com as armas da Guarda Nacional, o que dava um peso militar às reivindicações; as jornadas de julho e de outubro lembravam aos constituintes em Versalhes que tinham uma dívida para com a insurreição popular; a vitória convenceu as mulheres de que valia a pena "tomar o poder" das autoridades incapazes de resolver seus problemas, como fizeram na Assembléia; estabeleceu-se um padrão de ação em insurreições: as mulheres iniciam o movimento, os homens as seguem armados, depois as mulheres os apóiam, e os dois sexos lutam ombro a ombro; a definição popular de soberania como o exercício da democracia direta foi posta em prática no dia 5 de outubro na Assembléia Nacional ${ }^{177}$; havia começado a erosão da autoridade antes sacrossanta do monarca, e os súditos se transformaram em cidadãos militantes; tendo combatido, as mulheres não iam concordar em ficar à margem dos acontecimentos, pois o combate traz direitos: a partir das jornadas de outubro, elas estariam no centro dos movimentos populares revolucionários. Além disso, o povo se conscientizou de que as insurreições eram eficazes para garantir a subsistência. levante popular se justificava pelo bem comum, e se legitimava como braço armado da nação soberana. O fundamento moral da insurreição era a Declaração dos direitos do homem e do cidadão, principalmente o direito à existência - e portanto à alimentação , e o direito de resistência à opressão. Os cidadãos que na Constituição de 1791 seriam classificados como passivos, inclusive as mulheres, constataram que sua intervenção política podia mudar o curso da Revolução.

As autoridades enxergaram a mesma coisa e se assustaram com a força da multidão revolucionária. Sua resposta mais imediata às jornadas de outubro foi a

\footnotetext{
${ }^{177}$ APPLEWHITE, Harriet B. \& LEVY Darline G. "Responses to the Political Activism of Women of the People in Revolutionary Paris, 1789-1793. IN Women and the Structure of Society - Selected research from the fifth Berkshire Conference on the History of Women., edited by Barbara J. Harris and JoAnn K. McNamara. Duke Press Policy Studies, 1984, p. 223.
} 
centralização do poder e a tentativa de desacreditar a Marcha, denegrir as mulheres e duvidar de sua autonomia. O inquérito do Châtelet que investigou os acontecimentos fez perguntas dirigidas que apontavam para uma suposta conspiração do Duque de Orléans. As mulheres teriam sido compradas, estavam embriagadas, e algumas nem sequer eram mulheres, mas sim homens travestidos ${ }^{178}$. Era preciso minimizar o papel e a ameaça das manifestantes parisienses. Tarefa difícil: entre todas as rebeliões populares da Revolução, os dias de outubro se destacam como uma insurreição feminina 179 .

Além do processo criminal e da campanha de descrédito, outra maneira de neutralizar a iniciativa das ativistas foi a idéia de atribuir sua inspiração à deusa da Liberdade, ou à Providência. Quatro anos depois, em 10 de agosto de 1793, durante a Festa da Regeneração planejado por Jacques-Louis David (ver duas imagens da Festa no Capítulo 2). Hérault de Séchelles homenageou as "heroínas de outubro" mitologizando o evento histórico da Marcha para Versalhes. " A fraqueza do sexo, o heroísmo da coragem!" disse ele. Em seguida, atribuiu a vitória de sete mil mulheres acompanhadas pela Guarda Nacional e civis armados aos milagres da deusa da Liberdade ${ }^{180}$. As "frágeis" protagonistas tinham sido apenas instrumentos da deusa. A coreografia de David incluía algumas mulheres montadas nos canhões, debaixo de um arco comemorativo onde se lia " elas expulsaram o tirano como uma presa vil". A história se repete como farsa? Acho que este caso ilustra a idéia de Marx: o drama real se transformou em espetáculo. Houve uma sublimação do pesadelo da inversão de papéis, das mulheres comandando e subjugando um símbolo masculino de força - 0 canhão. Nesse ambiente delimitado e controlado, desapareceram a paixão, a violência e o heroísmo que tanto fascinaram e inquietaram os governantes. Em seu lugar ficaram personagens de pantomima.

\footnotetext{
${ }^{178}$ APPLEWHITE, Harriet B. \& LEVY Darline G. "Responses to the Political Activism of Women of the People in Revolutionary Paris, 1789-1793. IN Women and the Structure of Society - Selected research from the fifth Berkshire Conference on the History of Women., edited by Barbara J. Harris and JoAnn K. McNamara. Duke Press Policy Studies, 1984, p. 222

${ }^{179}$ LEVY, Darline G., APPLEWHITE, Harriet B., JOHNSON, Mary D. - Women in Revolutionary

Paris - 1789-1795 - . Selected documents translated with notes and commentary by the authors Urbana e Chicago, University of Illinois Press, 1980, p. 17.

${ }^{180}$ LEVY, Darline G. e APPLEWHITE Harriet B. "Women and Militant citizenship in Revolutionary Paris” IN MELZER, Sara E. And RABINE, Leslie W. (editoras), Rebel Daughters -Women and the French Revolution, New York - Oxford, Oxford University Press, 1992, p. 94.
} 
Dando mais um passo na direção da "domesticação" das ativistas, Hérault, Presidente da Convenção Nacional, aproveitou para lembrar às homenageadas que depois do seu grande feito, seu papel na Revolução era dar a luz "a um povo de heróis" e nutri-los com leite materno para que desenvolvessem a virtude marcial ${ }^{181}$. Naquela época, achava-se que o leite transmitia à criança as qualidades morais de quem amamentava, portanto podemos pensar que o orador reconhecia virtudes marciais naquelas mulheres. O leite materno formava cidadãos, ao contrário do "leite mercenário" das amas contratadas. O Festival da Regeneração representou o paroxismo da campanha do aleitamento materno. Por outro lado, o culto à maternidade cívica excluía a mulher do espaço público exaltando seu dever de gerar patriotas.

Em nome da moral republicana, era preciso incentivar as militantes a voltarem ao seu lugar no lar e na família. À época, a sans-culotterie atingia o auge de seu poder, e as ativistas estavam presentes no Festival na qualidade de membros do Povo Soberano, não em sua função privada de mães. Mas era preciso transformar aqueles seres políticos em exemplos de esposas e mães dedicadas à família. Em outubro de 1793 os clubes políticos femininos foram proibidos. E em dezembro de 1793, significativamente, aprovou-se uma lei estipulando que nas cerimônias cívicas as patriotas de outubro teriam um lugar especial "onde estarão presentes com seus maridos e crianças, e onde tricotarão"'" (Moniteur, XIX, 85 - 11 nivose) ${ }^{182}$. Agora havia uma lei determinando o comportamento das heroínas nos festivais: em vez de homenagear seu heroísmo patriótico, pretendiam exaltar sua condição materna. Ironicamente, o símbolo da nova domesticidade das militantes de outubro de 1789 era o mesmo tricô que, quando executado pelas freqüentadoras das tribunas, era transgressor e repulsivo. Tratava-se de devolver a doçura e o aconchego ao ato de tricotar. E fazê-lo em público, com as militantes rodeadas de suas crianças, com o máximo de estardalhaço! As relações entre militância, maternidade e representações femininas das virtudes republicanas são complexas e não se esgotam nestes breves comentários. A questão será apreciada do ponto de vista iconográfico no Capítulo 2 - Representações Femininas.

\footnotetext{
${ }^{181}$ LEVY, Darline G. e APPLEWHITE Harriet B. "Women and Militant citizenship in Revolutionary Paris” IN MELZER, Sara E. And RABINE, Leslie W. (editoras), Rebel Daughters -Women and the French Revolution, New York - Oxford, Oxford University Press, 1992, p. 94.

${ }^{182}$ A citação está IN BLUM, Carol, Rousseau and the Republic of Virtue - The language of Politics in the French Revolution, Ithaca and London, Cornell University Press, 1986 , p. 215.
} 
A presença do Rei em Paris não foi suficiente para garantir o abastecimento de farinha de trigo na cidade, e passadas duas semanas, os distúrbios continuavam, um padeiro foi linchado, e um manifestante enforcado. O problema foi resolvido através de medidas conjuntas da Communa de Paris e da Assembléia Nacional recém instalada na capital. Os deputados, que agora podiam prescindir do apoio popular, restauraram a ordem por meio de uma repressão feroz: foi decretada a censura à imprensa, a pena de morte para sedições, e a lei marcial. Só no mês de novembro, depois que o preço do pão caiu para doze sous, a paz social voltou a reinar em Paris 183

\section{8 - A conscientização política}

Embora o foco desta dissertação seja a militante das classes populares, é importante perceber que essas mulheres não foram as únicas a participarem da vida política revolucionária. As damas das classes privilegiadas tinham consciência das mudanças radicais na organização política, social e econômica do país, as quais necessariamente afetariam seu círculo familiar e camada social. Mas o interesse feminino ia além da esfera pessoal.

No verão de 1789, com exceção das aristocratas que emigraram junto com seus pais e maridos, a maioria das mulheres parisienses recebeu a Revolução com entusiasmo $^{184}$. Algumas aristocratas freqüentavam as tribunas da Assembléia Constituinte, como a Condessa de Chalabre, fascinada por Robespierre ${ }^{185}$. Era de bom tom assistir aos debates da Assembléia e sessões do Clube dos Jacobinos - mas essas senhoras eram apenas espectadoras, ouviam e aplaudiam, não tomavam a palavra. No máximo, poderiam tentar influenciar algum deputado que freqüentasse a sua casa. A

\footnotetext{
183 MARAND-FOUQUET, Catherine, La femme au temps de La Révolution - Paris, Éditions Stock/Laurence Pernoud, 1989, pp. 79-80.

${ }^{184}$ LEVY, Darline G., APPLEWHITE, Harriet B., JOHNSON, Mary D. - Women in Revolutionary

Paris - 1789-1795 - . Selected documents translated with notes and commentary by the authors Urbana e Chicago, University of Illinois Press, 1980, p. 14.

${ }^{185}$ MARAND-FOUQUET, Catherine, La femme au temps de La Révolution - 1989, Éditions

Stock/Laurence Pernoud, P. 110.
} 
exceção notável foi Madame de Staël, filha de Necker e principal égerie ${ }^{186}$ de seu tempo: exercia uma influência real sobre determinados representantes. Alguns, como Narbonne e Tayllerand, deviam seus cargos à sua intervenção pessoal. Germaine de Staël amargou um prolongado exílio, pois todos os governos que se sucederam entre 1792 a 1814 tiveram a preocupação comum de mantê-la afastada de Paris, onde ela aspirava fazer de seu salão um dos grandes corpos de Estado (corps d'État) ${ }^{187}$. Apesar de sua ambição política, Staël nunca reclamou direitos cívicos para as mulheres. Contudo, achava que elas podiam influenciar os homens de Estado, papel que ela própria desempenhou à merveille! Realmente, o "direito à influência" é uma reivindicação bem pálida se comparada à Declaração dos direitos da mulher de Olympe de Gouges, guilhotinada em 1793. Staël comparecia assiduamente às galerias da Assembléia Nacional, de onde se dizia que mandava bilhetes aos deputados no plenário instigando-os a apoiarem moções patrióticas.

Mme. Manon Roland, que pertencia à burguesia educada, não acreditava nesses rumores, pois para ela a participação direta das mulheres na política era inconcebível , no que compartilhava a visão da maioria de seus contemporâneos: "Creio que nossos costumes ainda não permitem que as mulheres se mostrem [na cena política]. Elas devem inspirar o bem e nutrir, inflamar todos os sentimentos úteis à pátria, mas sem parecer concorrer à obra política"188 (grifo meu). Sempre discreta, em público fazia questão de ficar à sombra do marido, apesar da influência expressiva que exerceu sobre Roland e o grupo de políticos que frequentavam sua casa. O cuidado de "não parecer" influente não a livrou da condenação à morte, pois seu papel de mentora política do marido e inspiradora dos girondinos era bem conhecido de seus inimigos.

As burguesas em geral ficavam no recesso do lar, mas, se suas famílias corressem perigo, mostravam coragem e determinação para salvá-las. Durante os Estados Gerais, em 1789, alguns estudantes de direito e medicina foram presos pelos nobres de Angers. As mulheres se reuniram e publicaram o texto:

\footnotetext{
${ }^{186}$ Mme. de Staël foi a égerie por excelência, a ponto de seu nome se tornar sinônimo do termo; o dicionário Petit Robert (1973, p. 545) exemplifica o sentido da palavra com o papel que ela exerceu na política: "conseillère, inspiratrice d'un homme politique" "Son ambition (de Mme. de Staël) visait à être l'Égerie des hommes d'État”.

${ }^{187}$ DISBACH,Ghislain de - Madame de Staël, Paris, Perrin 1997, p. 10.

${ }^{188}$ ROSA, Annette, Citoyennes, Paris, Messidor, 1988 , p. 81.
} 
nós, mães, irmãs, esposas e amantes dos jovens cidadãos da cidade de Angers (...) declaramos que, se os problemas recomeçarem, e, no caso de partida (...) nós nos uniremos à nação, cujos interesses são os nossos (...) e nos encarregaremos das bagagens, provisões, e todos os cuidados, consolações e serviços que dependerem de nós (...) preferindo a glória de compartilhar seus perigos à segurança de uma inação vergonhosa ${ }^{189}$.

A linguagem das angevinas é política : a identidade de interesses com a nação, e pertencimento ao corpo político. A motivação principal é a defesa dos entes queridos, mas a argumentação é eivada de civismo. Elas assumiram o papel feminino tradicional de coadjuvantes nos serviços de retaguarda mas já usam a retórica revolucionária da nação unida contra a tirania. A "inação" é indigna delas, que sentem, portanto, o dever de agir. Aliás, a expressão "inação vergonhosa" foi usada muitas vezes pelas mulheres engajadas quando questionadas sobre o motivo de sua intervenção política durante a Revolução. Algumas mulheres não se contentaram com o papel de coadjuvantes, queriam uma participação direta na vida nacional - estou me referindo às militantes.

Quem eram as militantes? As revolucionárias em questão, agindo sozinhas ou como grupo de mulheres, não estavam isoladas, à margem do movimento popular. Ao contrário, nele se encontravam plenamente integradas, como seu elemento feminino. A maioria dessas mulheres eram das classes populares: lavadeiras, costureiras, artesãs, pequenas comerciantes, criadas domésticas. Elas tinham uma vida social ligada ao trabalho, à família, à vida cotidiana e política nas seções de Paris, o que permitia que tivessem relações com os integrantes masculinos de diversas vertentes do movimento revolucionário. Porém, como explica Godineau ${ }^{190}$, as mulheres não se engajaram na Revolução da mesma forma, havia várias tendências políticas e interesses diferentes em seu meio. Não se trata de um grupo monolítico, a exemplo do próprio movimento revolucionário, o qual incluía os Girondinos, Montanheses, Enragés, Cordeliers, entre outros. Em alguns momentos, entretanto, elas intervieram no curso da Revolução de forma dramática, e como grupo de mulheres, como percebemos na documentação existente: na Marcha para Versalhes em outubro de 1789, quando trouxeram o Rei de volta a Paris, na primavera e verão de 1793 durante a luta entre os

\footnotetext{
${ }^{189}$ Archives parlementaires de 1787 à 1860, 1re. Série, Paris, 1867-1868, p. 531 IN MARANDFOUQUET, Catherine, La femme au temps de La Révolution - 1989, Éditions Stock/Laurence Pernoud pp.32-33.

${ }^{190}$ GODINEAU, Dominique, "Masculine and Feminine Political Practice during the French Revolution, 1793 - Year III" IN APPLEWHITE, Harriet B. \& LEVY Darline G. (edited by) Women \& Politics in the Age of the Democratic Revolution, Ann Arbor, The University of Michigan Press, 1993,
} 
deputados Girondinos e Montanheses, e na grande insurreição de Prairial (20-23 de maio de 1795) que marcou a derrota da sans-culotterie e o fim da participação feminina na Revolução.

Como o grau de envolvimento e a motivação das mulheres não era uniforme, impõe-se uma categorização do componente feminino do movimento popular. Assim, adoto aqui a definição geral de Godineau, que considera militantes as mulheres que respondem aos seguintes critérios: pertencem às sociedades ou clubes políticos que aceitam mulheres ou freqüentam assiduamente as tribunas das assembléias revolucionárias; participaram de pelo menos duas jornadas insurrecionais; outros indicadores são comentários terroristas de natureza política, a prática de denúncias quando acompanhadas por outros elementos característicos da mentalidade sans-culotte. Em outras palavras, são pessoas que demonstram um interesse continuado pela política, e cujos nomes nos arquivos não se devem apenas à indignação passageira com o preço ou escassez de alimentos. Essas militantes formam a sans-culotterie feminina, um grupo fluido mas expressivo, cujas ações e reações freqüentemente dependiam do estatuto social e político feminino. Paralelamente, muitas parisienses das camadas populares participaram de algumas jornadas revolucionárias, como a Marcha para Versalhes, ou o levante de Prairial, sem serem necessariamente militantes. Eram, porém, apegadas aos ideais da Revolução e compartilhavam as aspirações da sansculotterie: o direito à existência, ligado à segurança alimentar, o igualitarismo, a defesa da soberania e felicidade do povo. Os dois grupos juntos formaram o que se convencionou chamar de "massas populares femininas"191.

Todos respiravam política na Paris revolucionária. O povo se mantinha bem informado e atento aos acontecimentos freqüentando sociedades populares, assistindo oradores como Camille Desmoulins no Palais Royal, lendo alguns dos sessenta e nove jornais e panfletos criados entre julho e agosto de $1789^{192}$ ou discutindo em grupos as notícias dos jornais lidos em voz alta nas esquinas. As mulheres se encontravam quase diariamente nas filas de pão, nos ateliês de trabalho, nas ruas, cafés, mercados, salas de jogo do Palais-Royal e nesses espaços de sociabilidade discutiam

191 GODINEAU, Dominique, Citoyennes Tricoteuses - Les femmes du peuple à Paris pendant la Révolution Française, Paris, Editions Alinea, Perrin, 2004 , pp. 123-4

192 MARAND-FOUQUET, Catherine, La femme au temps de La Révolution - 1989, Éditions Stock/Laurence Pernoud, p. 62. 
com entusiasmo os assuntos da cidade. À noite, as lavadeiras se encontravam na taberna para trocar impressões sobre os discursos dos oradores revolucionários. Ocasionalmente, vizinhas chegavam às vias de fato porque uma preferia os Girondinos e outra os Montanheses ${ }^{193}$.

Em relação à efervescência política reinante na capital francesa, Elisabeth Sledziewski ${ }^{194}$ menciona o testemunho de Joachim Campe, um viajante alemão , o qual escreveu de Paris aos seus conterrâneos manifestando grande surpresa com o "caloroso interesse que esta gente, que na sua maior parte não sabe ler nem escrever, demonstra pelos assuntos públicos" e notou que " a participação de todos parece ser necessária para discutir acerca de tudo" e que " "grupos numerosos [...] de homens e de mulheres, os mais diversos" estavam presentes, entre os quais "vendedoras de peixe e damas elegantes" . As ruas e as praças de Paris se tornaram escolas de civismo e as mulheres aprendiam na prática, junto com os homens, o conceito de cidadania. Joachim Campe observou argutamente: "imaginem um instante o efeito [...] desta participação de todos na coisa pública sobre o desenvolvimento das faculdades intelectuais, da inteligência e da razão!"195.

A conscientização política despertou no povo, inclusive nas mulheres, o sentimento de pertencimento ao corpo político da nação. Aos poucos, aumentou o número de pessoas que perceberam o impacto da política nas suas vidas privadas. As mulheres queriam ter acesso às autoridades do governo para influenciar de alguma forma as decisões que afetavam o seu cotidiano. As sans-culottes sabiam os nomes dos ministros responsáveis pelas políticas de abastecimento e trabalho. Novas instituições democráticas foram criadas, como as assembléias das seções e as sociedades populares, e as tribunas desse foros se abriram ao público, contribuindo para a criação

\footnotetext{
193 GODINEAU, Dominique, «Filhas da liberdade e cidadãs revolucionárias” IN DUBY, Georges e PERROT, Michelle (direção da coleção) e FRAISSE, Geneviève e PERROT, Michelle (direção do volume 4) História das Mulheres no Ocidente, vol. 4, Do Renascimento à Idade Moderna (trad.) Porto, Ed. Afrontamento, 1994, pp. 27-28.

${ }^{194}$ GUIBERT-SLEDZIEWSKI, Elizabeth , “Revolução Francesa. A viragem” IN DUBY, Georges e PERROT, Michelle (direção da coleção) e FRAISSE, Geneviève e PERROT, Michelle (direção do volume 4) História das Mulheres no Ocidente, vol. 4, Do Renascimento à Idade Moderna (trad.) Porto, Ed. Afrontamento, 1994, pp. 46-47.

${ }^{195}$ CAMPE, Joachim, Lettres d'un allemand à Paris, 9 de agosto de 1789, trad. fr. J. Ruffet, Paris, 1989 IN GODINEAU, idem.
} 
de uma cultura política sofisticada até entre pessoas praticamente sem instrução ${ }^{196}$. Mulheres de todas as classes sociais aprenderam a utilizar tais organismos em seu favor, comparecendo, tomando parte nos debates, participando diretamente da elaboração de petições, formação de delegações e organização de protestos. As cidadãs pressionavam o governo por nova legislação para questões como o preço de cereais, a educação, o divórcio e casas de saúde ${ }^{197}$.

Em Paris e nas províncias, a Festa da Federação em 14 de julho de 1790 marcou o ápice do sentimento de concórdia e união dos franceses na Revolução: os homens se reconheceram semelhantes e se surpreenderam por terem ignorado uns aos outros por tanto tempo, escreveu um Michelet enternecido e admirado - além disso,

nós afastamos as mulheres da vida pública, mas esquecemos que elas têm mais direito a ela do que ninguém [...] o homem só arrisca a sua vida, a mulher traz consigo seu filho... ela está muito mais interessada em se informar e se precaver[...] chamadas ou não, elas tomaram parte vivamente das festas da Federação ${ }^{198}$.

Em Orléans, as mulheres participaram do juramento cívico no altar da pátria, e havia um estrado reservado às "Cidadãs patriotas", vestidas de branco, cocarda e cintos tricolores. A mulher do coronel da Guarda Nacional Dulac dirigiu algumas palavras ao Prefeito:" Tudo aqui nos faz lembrar que temos direito à felicidade pública. Sim, Senhores, nós somos francesas, esposas e mães; e esses direitos sagrados da natureza , acaso não deixam em nossas mãos a felicidade das gerações futuras? "199 . Percebe-se aqui o orgulho das mulheres que aderiram ao conceito da maternidade cívica, a qual acarretava direitos porque elas cumpriam o papel que lhes fora reservado. E deduz-se que a idéia da cidadania estava ligada ao estado civil de casadas, ou seja, da respeitabilidade pessoal. Madame Roland publicou seus comentários entusiasmados sobre o desfile dos federados em Lyon: "Vê-se destacamentos de mulheres com sabre na mão, num passo firme e guerreiro, mostrando por trás de sua vestimenta feminina um

\footnotetext{
${ }^{196}$ LEVY, Darline G., APPLEWHITE, Harriet B., JOHNSON, Mary D. - Women in Revolutionary Paris - 1789-1795 - . Selected documents translated with notes and commentary by the authors Urbana e Chicago, University of Illinois Press, 1980, p. 11.

197 LEVY, D., BRANSON APPLEWHITE, H., JOHNSON, M. - Women in Revolutionary Paris 1789-1795 - . Selected documents translated with notes and commentary by the authors, University of Illinois Press p. 9-10

${ }^{198}$ MICHELET, Jules, Histoire de la Révolution Française, Paris, Editions Robert Laffont, 1979, livre premier, pp. 325-328.

${ }^{199}$ MARAND-FOUQUET, Catherine, La femme au temps de La Révolution - Paris, Éditions Stock/Laurence Pernoud, 1989, pp. 87, 90, 91.
} 
espetáculo de amazonas e a coragem de Joana d"Arc" ${ }^{200}$. Considerando suas opiniões contrárias à desenvoltura feminina no espaço público, penso que Manon Roland aceitava as cidadãs armadas porque integravam a liturgia da festa, numa coreografia ensaiada que não conferia poder real a quem participava. Concordava com uma "cidadania ornamental ", por assim dizer. Mas, não se pode menosprezar a força dos rituais e dos símbolos, os quais certamente inspiraram algumas a reivindicar o porte de armas para a defesa da nação, uma das prerrogativas da cidadania.

Em Paris as mulheres ajudaram com o trabalho pesado da preparação do Campo de Marte durante toda a semana que antecedeu a Festa da Federação, carregando carrinhos de terra para construir um imenso anfiteatro natural no local. A iconografia interpretou este momento significativo numa variedade de trabalhos. Os redatores de um jornal contemporâneo ficaram impressionados com mistura de classes sociais , mais que com a presença feminina, e relatam como um Cavaleiro de Saint-Louis seguiu o exemplo das mulheres e resolveu ajudar nos trabalhos: "mães que colocaram seu bebê [...] para puxar o carrinho de mão; moças suadas que não tinham a força dos homens , porém eram mais ardorosas [na tarefa]; uma mãe respeitável com suas três filhas cada uma com seu carrinho de terra" ${ }^{201}$. Talleyrand rezou uma missa solene e La Fayette prestou o juramento cívico, seguido das vozes dos 300.000 espectadores fazendo o juramento coletivo que seguia a tradição da comunhão cristã: " o povo estava agora constituído, soberano e consagrado"202. No meio da multidão, participando do ritual cívico ao lado dos homens, não surpreende que as mulheres se sentissem também membros do "souverain", ou povo soberano. Elas estavam vivendo a cidadania.

Um ano depois o clima político era de pessimismo. A Constituição Civil do Clero causou uma ruptura na vida religiosa, daí em diante ministrada oficialmente pelo clero constitucional, ou "jurado", ou clandestinamente pelos religiosos que não aceitaram a nova lei, os "refratários". Os fiéis também se dividiram em dois grupos, segundo sua lealdade religiosa e revolucionária. Em 1791, homens e mulheres membros das sociedades fraternais (que admitiam os dois sexos) expressavam sua

\footnotetext{
${ }^{200}$ idem, p. 87.

${ }^{201}$ Le véritale Ami de la Reine ou Journal des Dames par une Société de Citoyennes - 1790 IN LUCAS, Colin, Editor-in-Chief The French Revolution Research Collection, University of Chicago, 1992 , The New York Public Library, microficha 9.4/173.

${ }^{202}$ ROSA, Annette, Citoyennes, Paris, Messidor, 1988, p. 91.
} 
desconfiança dos aristocratas, da Assembléia Nacional e do Rei. As mulheres participaram de protestos contra as novas leis que proibiram petições coletivas, e a lei Le Chapelier que abolia guildas e proibia todas as organizações profissionais e operárias $^{203}$. Em meio à crise constitucional, o Rei e a família real foram capturados em Varennes depois de uma fracassada tentativa de fuga. Uma Assembléia Nacional temerosa se recusou a suspender o Rei. O ultra patriótico Clube dos Cordeliers fez uma campanha, juntamente com outras sociedades populares, para substituir a monarquia pela república. No dia 14 de julho de 1791 grande número de pessoas reuniram-se no Campo de Marte em Paris para elaborar e assinar uma petição à Assembléia questionando a legitimidade do Rei traiçoeiro. Entre os signatários havia os nomes de quarenta e uma mulheres, num bloco separado dos homens. Supõese que elas tivessem consciência do que assinaram e estavam dispostas a revelar sua opinião num documento público:

Os franceses escolheram representantes para lhes darem uma constituição, e não para restaurar um líder que trai e quebra seus juramentos mais sagrados [...] Os cidadãos [...] pedem aos representantes da Nação que não legislem nada de definitivo em relação ao destino de Luís XVI até que as comunas expressem seus desejos e a voz da massa do povo seja ouvida [...] qualquer decreto que ultrapassar os limites circunscritos aos Senhores será declarado nulo [...] e considerado uma afronta aos direitos do soberano, o povo, o povo ${ }^{204}$.

Decididamente, o povo exigia ser ouvido acerca do destino do Rei, e esta petição marca o início da crise entre as massas convertidas aos ideais republicanos e a burguesia que dominava a Assembléia Nacional, ainda favorável à monarquia constitucional. O documento traz à luz a questão do controle democrático dos eleitos, e limites do poder legislativo. No dia 17 de julho, informada de que havia um grande ajuntamento de peticionários no Campo de Marte, a Assembléia convocou a Guarda Nacional para reprimir o "levante" e decretou a lei marcial. Um soldado testemunhou que ali havia apenas cidadãos pacíficos que passeavam com as famílias no domingo. Não obstante, o batalhão comandado por La Fayette, autorizado pelos representantes da nação, abriu fogo sobre o povo de Paris, matando cinqüenta pessoas.

\footnotetext{
${ }^{203}$ LEVY, Darline G., APPLEWHITE, Harriet B., JOHNSON, Mary D. - Women in Revolutionary Paris - 1789-1795 - . Selected documents translated with notes and commentary by the authors Urbana e Chicago, University of Illinois Press, 1980, pp. 63-64.

${ }^{204}$ Fonte: Albert Mathiez, Le Club des Cordeliers pendant la crise de Varennes et le massacre du Champ de mars, pp. 112-15, reimpressão do texto da petição à Assembléia Nacional de 14 de julho de 1791, com assinaturas IN LEVY, Darline G., APPLEWHITE, Harriet B., JOHNSON, Mary D. Women in Revolutionary Paris - 1789-1795 - . Selected documents translated with notes and commentary by the authors - Urbana e Chicago, University of Illinois Press, 1980, pp. 78-79.
} 
Expressando a consternação geral com o massacre, Madame Roland escreveu: "Não estamos mais em 1789; prepararam correntes para nós"205. A ação brutal marcou o fim do período em que parecia possível à Revolução Francesa transformar completamente a sociedade, apagando todos os vestígios do Antigo Regime, apenas com a força de seus ideais ${ }^{206}$. Havia mulheres entre os detidos na manifestação, entre elas, a ativista holandesa Etta Palm d"Aelders e outras senhoras da classe média educada. A cozinheira Constance Evrard, que tinha ido ao Campo de Marte com Pauline Léon futura fundadora e presidente da Sociedade das Republicanas Revolucionárias também foi presa nesse dia. Interrogada pela polícia, respondeu que havia ido ao "altar da pátria" para "assinar a petição como todos os bons patriotas", e o objetivo da petição era "reorganizar o poder executivo". Declarou que freqüentava o Clube dos Cordeliers, o Palais Royal e costumava ler os jornais de Marat, Desmoulins, Audouin e o L'Orateur du Peuple ${ }^{207}$. Outro testemunho dos acontecimentos do Campo de Marte naquela data foi o de um menino de onze anos, o qual relatou ter visto uma senhora de idade que não sabia escrever pedindo ao filho que assinasse seu nome na petição ${ }^{208}$. É interessante notar a mistura de sexos e classes sociais no acontecimento. As mulheres do povo, inclusive as iletradas, faziam sua parte comparecendo e assinando a petição, e pareciam entender os objetivos políticos daquele ato cívico. Elas estavam dispostas a desafiar os poderes constituídos porque, além da convicção política, tinham o sentimento de pertencer ao povo soberano, àquele grupo de "bons patriotas" que marcaram presença no Campo de Marte.

\footnotetext{
${ }^{205}$ ROSA, Annette, Citoyennes, Paris, Messidor, 1988 , pp. 93-94.

${ }^{206}$ KATES, Gary, “ The Powers of Husband and Wife must be Equal and Separate' : The Cercle social and the Rights of women, 1790-1791”. IN APPLEWHITE, Harriet B. \& LEVY Darline G. (edited by) Women \& Politics in the Age of the Democratic Revolution, Ann Arbor, The University of Michigan Press, 1993, p. 176-177.

207 Documento "Interrogatório do comissário de polícia da Section Fontaine de Grenelle de Constance Evrard, cozinheira de 23 anos de idade (...)" Arquivos da Préfecture de Police de Paris, Aa 148, fol. 30, xx IN LEVY, Darline G., APPLEWHITE, Harriet B., JOHNSON, Mary D. - Women in Revolutionary Paris - 1789-1795 - . Selected documents translated with notes and commentary by the authors - Urbana e Chicago, University of Illinois Press, 1980, pp. 81-82 .

208 idem, pp. 83-84.
} 


\section{$\underline{1.9-\text { Vozes feministas }}$}

Depois que a Assembléia Nacional promulgou a "Declaração de Direitos do Homem e do Cidadão" em agosto de 1789, algumas vozes feministas ${ }^{209}$ se fizeram ouvir a respeito dos direitos da mulher na sociedade francesa. Os princípios que pautaram esses escritos proclamavam que homens e mulheres nascem racionais em sua humanidade, iguais em seus direitos. A exclusão da mulher da vida política seria uma afronta aos princípios de igualdade enunciados na Declaração, e portanto, um ato de tirania. Apesar da pressão feminina, os deputados que elaboraram a Constituição de 1791 não incluíram a legislação considerada mais essencial para o sexo: o direito ao divórcio, oportunidades iguais de educação fundamental para as meninas e regulamentação sobre serviços de saúde para a mulher. Não houve nenhuma consideração séria de sufrágio feminino, e os homens foram divididos em cidadãos ativos e passivos: os primeiros pagavam impostos de no mínimo três dias de salário, podiam servir na Guarda Nacional e participar de eleições locais e nacionais; os segundos não atingiam a renda necessária e não podiam votar nem portar armas ${ }^{210}$. As mulheres estavam nessa segunda categoria e não eram cidadãs no sentido político do termo, assim como as crianças, os loucos, os menores de idade, os criados domésticos, os condenados a penas aflitivas ou infamantes até sua reabilitação ${ }^{211}$. Considerava-se que essas pessoas não tinham independência de julgamento - um dos critérios para pertencer ao corpo eleitoral - e suas vontades estavam atreladas à de outrem ${ }^{212}$, no caso feminino às dos pais e maridos. Nem por isso as mulheres estavam menos sujeitas às penas da lei: sem direitos políticos, podiam ser condenadas por crimes políticos. Aos olhos dos legisladores, as execuções de mulheres eram legítimas ${ }^{213}$. Nem todos concordavam com esses preceitos, e surgiram alguns notáveis escritos

\footnotetext{
${ }^{209}$ O termo "feminista" não existia no século XVIII. A palavra "feminismo" não era conhecida antes do século XIX, e teria sido inventada por Charles Fourier, ver LANDES, Joan B., Women and the Public Sphere in the age of the French Revolution, Ithaca and London, Cornell University Press, 1988, p. 207, nota no. 1.

${ }^{210}$ LEVY, Darline G., APPLEWHITE, Harriet B., JOHNSON, Mary D. - Women in Revolutionary

Paris - 1789-1795 - . Selected documents translated with notes and commentary by the authors Urbana e Chicago, University of Illinois Press, 1980, pp. 61-62.

${ }^{211}$ DUHET, Paule-Marie, Les Femmes et la Révolution 1789-1794, Paris, Gallimard/Julliard $1971 \mathrm{p}$. 166.

${ }^{212}$ FURET, Francois, e OZOUF, Mona, Dictionnaire Critique de la Révolution Française:

Institutions et Créations, Événements, Idées, Acteurs - Champs, Flammarion 1992. vol. Institutions et Créations, verbete "suffrage", p. 332.

${ }_{213}$ DUHET, Paule-Marie, Les Femmes et la Révolution 1789-1794, Paris, Gallimard/Julliard 1971, p.166.
} 
feministas denunciando a exclusão das mulheres de seus direitos naturais e imprescritíveis, como os de Condorcet. No artigo "Sobre a Admissão das mulheres ao Direito de Cidade" (julho de 1790), o autor apontou o absurdo de se falar do princípio da igualdade de direitos para trezentos ou quatrocentos homens e esquecê-lo em relação a doze milhões de mulheres. E chegou a propor que as mulheres deveriam ter o direito de votar e serem votadas, pois tinham capacidade para a vida pública: " não se deve acreditar que se as mulheres fossem membros das assembléias nacionais abandonariam imediatamente suas crianças, seu lar, sua agulha. Elas estariam mais preparadas para educar seus filhos e a formar os homens. (...) "214. Para ele, a maternidade e a vida política conviveriam com proveito para ambas. Condorcet refutava o argumento de que a constituição feminina era um obstáculo à igualdade dos sexos, dizendo que as indisposições passageiras das mulheres não poderiam privá-las de direitos que não eram negados àqueles que sofriam de gota todos os invernos ou se resfriavam facilmente. As idéias de Condorcet sobre os direitos cívicos femininos tiveram pouca ressonância entre os líderes revolucionários.

As principais personalidades feministas do início da Revolução foram Olympe de Gouges, Etta-Palm d"Aelders e Théroigne de Méricourt. A autodidata Olympe de Gouges era filha de um açougueiro do Languedoc, e freqüentava o Palais Royal, que a partir de 1789 se tornou um centro de movimentação revolucionárias. Assim como muitas outras mulheres, Olympe se preocupava com a miséria e a dívida pública, e em 1788 propôs contribuições voluntárias para a formação de uma caixa patriótica em Carta ao Povo ou Projeto de uma Causa Patriótica. Apelou para o desprendimento das pessoas com certa dose de ingenuidade: “ “...) em vez de comprar dez chapéus de estilos diferentes, as mulheres conscientes (...) se contentarão com um ou dois chapéus de bom gosto e o que sobrar será enviado a essa Caixa”215. Ela gastava suas economias na impressão de panfletos e cartazes para divulgar suas idéias. Feminista radical, Olympe de Gouges queria o fim da "tirania que os homens exerciam sobre as mulheres", e para isso defendeu uma reforma do casamento que era, na sua opinião, um " túmulo do amor"; este passaria a ser um contrato social entre o homem e a mulher

\footnotetext{
${ }^{214}$ CONDORCET, "Sur l'admission des femmes au droit de cité" , 3 juillet, 1790, IN Journal de la Société de 1789 IN LUCAS, Colin, Editor-in-Chief The French Revolution Research Collection, University of Chicago, 1992 , The New York Public Library, microficha 9.4/207.

${ }^{215}$ GOUGES, Olympe - Oeuvres - présenté par Benoîte Groult - Paris, Mercure de France, 1986, Lettre au Peuple ou Projet d'une Cause Patriotique p. 72.
} 
pelo tempo que durassem as inclinações mútuas"216. Condenou a escravidão nas colônias, propôs o casamento dos padres “em nome dos bons costumes”, reclamou oficinas de trabalho para operários desempregados, asilos para órfãos e ajuda social aos miseráveis $^{217}$. Como resposta ao silêncio da Constituição de 1791 em relação aos direitos de cidade das mulheres, Olympe de Gouges publicou a sua Declaração dos

Direitos da Mulher e da Cidadã em setembro do mesmo ano, com o célebre artigo $\mathrm{X}$ : "ninguém pode ser inquietado por suas opiniões fundamentais, mesmo religiosas; a mulher tem o direito de subir ao cadafalso; tem que ter igualmente o direito de subir à tribuna”218. Feminista ousada, Gouges se arroga o direito de falar em nome das mulheres e reivindicar a igualdade cívica entre os sexos no artigo VI:

a Lei deve ser a expressão da vontade geral; todas as cidadãs e todos os cidadãos devem (têm o direito de ) concorrer pessoalmente, ou por seus representantes, à sua elaboração; ela tem que ser a mesma para todos ( para proteger ou punir) : todas as cidadãs e cidadãos sendo iguais aos seus olhos, devem ser igualmente admissíveis a todas as dignidades, posições e empregos públicos, segundo suas capacidades, e sem outras distinções que não sejam as das suas virtudes e seus talentos ${ }^{219}$.

Durante o processo de Luís XVI, em 11 de dezembro de 1792, Olympe de Gouges ofereceu-se para defendê-lo, penso que por sentimento de compaixão. Politicamente próxima dos Girondinos, seu pensamento por vezes não seguia uma tendência clara, era inconstante. Olympe foi, entretanto, uma ardorosa patriota, sem nunca recorrer à violência, a não ser a verbal. Alinhou-se aos Girondinos contra Robespierre mas alguns a consideravam monarquista. A partir de novembro de 1792, escreveu e assinou uma série de panfletos atacando Robespierre, chamando-o de algoz impiedoso $^{220}$. Morreu guilhotinada em 3 de novembro de 1793, poucos dias depois de Maria Antonieta. Em 19 de novembro, o Moniteur comentou sua trajetória: "Ela quis ser homem de Estado, e parece que a lei puniu esta conspiradora por ter se

\footnotetext{
${ }^{216}$ MARAND-FOUQUET, Catherine, La femme au temps de La Révolution - Paris, Éditions Stock/Laurence Pernoud, 1989, p.p. 103-104.

${ }^{217}$ MOUSSET, Sophie, Olympe de Gouges et les droits de la femme, Paris, Éditions du Félin, 2007, pp. 83, 99.

${ }^{218}$ MOUSSET, Sophie, Olympe de Gouges et les droits de la femme, Paris, Éditions du Félin,2007,p.91.

${ }^{219}$ idem, p. 89.

${ }^{220}$ ibidem, pp. 109-111.
} 
esquecido das virtudes que convêm ao seu sexo" ${ }^{221}$. Além da condenação política, Gouges sofreu uma censura moral por querer se imiscuir na seara masculina.

A auto-intitulada baronesa holandesa Etta-Palm d"Aelders, radicada em Paris, discursou e escreveu a favor dos direitos políticos da mulher. Fazia parte do Círculo Social, o qual fundou o primeiro clube político que admitia mulheres em outubro de 1790, a Confederação dos Amigos da Verdade ${ }^{222}$. Alguns dos membros mais ativos do Círculo - Brissot, Lanthenas - emergiram depois no cenário nacional como o núcleo dos Girondinos. O clube foi extinto quando os Girondinos foram expulsos da Convenção em junho de 1793. O Círculo Social se engajou numa campanha a favor do divórcio, e do fim da primogenitura. Etta Palm considerava que casamentos indissolúveis roubavam a liberdade das mulheres ${ }^{223}$. Em 1791, ela quis criar uma rede de sociedades patrióticas em cada seção parisiense e nas províncias, mas teve parcas adesões. Fundou uma sociedade com o objetivo de oferecer aprendizado de ofícios às meninas carentes. Sem apoio, não conseguiu suas escolas mas usou o dinheiro arrecadado para custear a educação de três meninas. Em dezembro de 1790, Etta-Palm $\mathrm{d}$ "Aelders pronunciou o discurso Apelo às francesas sobre a regeneração dos costumes e a necessidade de influência das mulheres num governo livre ${ }^{224}$ para os membros da Confederação dos Amigos da Verdade. Era a primeira vez que uma mulher subia ao pódio no clube revolucionário parisiense. A baronesa apelou ao senso de justiça dos representantes da "feliz nação que aplaude a coragem intrépida de suas Amazonas, e lhes permite formar um corpo para a defesa da pátria”. Depois de destruir as fortalezas que humilhavam os franceses, agora tinham que "destruir da mesma maneira as muralhas dos preconceitos, mais perigosas ainda para a felicidade geral”. A oradora se insurgiu contra uma "educação pueril mais apropriada para as escravas de um serralho do que para companheiras de homens livres" e contra as leis injustas sobre

\footnotetext{
${ }^{221}$ Moniteur, 19 de novembro, 1793, IN ROSA, Annette, Citoyennes, Paris, Messidor, 1988, p. 94. ${ }^{222}$ KATES, Gary, " The Powers of Husband and Wife must be Equal and Separate' : The Cercle social and the Rights of women, 1790-1791”. IN APPLEWHITE, Harriet B. \& LEVY Darline G. (edited by) Women \& Politics in the Age of the Democratic Revolution, Ann Arbor, The University of Michigan Press, 1993 p. 163,164.

${ }^{223}$ KATES, Gary, “ The Powers of Husband and Wife must be Equal and Separate’ : The Cercle social and the Rights of women, 1790-1791”. IN APPLEWHITE, Harriet B. \& LEVY Darline G. (edited by) Women \& Politics in the Age of the Democratic Revolution, Ann Arbor, The University of Michigan Press, 1993, p. 167.

${ }^{224}$ PALM D'AELDERS, Etta, Appel aux françoises sur la régenération des moeurs et necessité de l'influence des femmes dans un gouvernement libre, IN LUCAS, Colin, Editor-in-Chief The French Revolution Research Collection, University of Chicago, 1992, The New York Public Library, microficha no. 9.4/32.
} 
o adultério que só protegiam o sexo masculino. Clamou por uma reforma dos costumes para tirar a mulher da posição de inferioridade em que se encontrava e transformá-la em companheira voluntária do homem, em vez de sua escrava. O presidente da associação elogiou os "sentimentos patrióticos e a virtude heróica" de Etta Palm ${ }^{225}$.

Théroigne de Méricourt, de Liège, defensora da Revolução e aliada dos Girondinos, reivindicou o direito do porte de armas para as mulheres. Participou de espada na mão do ataque ao Palácio das Tulherias em 10 de agosto de 1792 - que resultou na queda da monarquia francesa - e foi condecorada por bravura. Théroigne participou da fundação de dois clubes mistos efêmeros, que fecharam as portas por falta de membros. Nas suas Confissões, Théroigne revela os sentimentos que a motivavam: “o amor do bem e a glória a conquistar ao me fazer útil à nação; mas eu não tinha nem talento nem a experiência para isso, e eu era mulher”226. Nas tribunas da Assembléia, ela era o alvo preferencial dos sarcasmos dos aristocratas. Suas idéias não eram insensatas, mas não foram acolhidas por nenhuma agremiação política. Por exemplo, propôs no clube dos Cordeliers a construção de um templo para alojar a Assembléia Nacional, no antigo lugar da Bastilha "para dar emprego a milhares de operários desocupados" e impressionar o povo: " o povo miúdo (le vulgaire) é atraído pelos sentidos: precisa de signos externos para seu culto (...)"227. A moção foi adotada, apresentada na Assembléia, mas não teve seguimento. Durante a luta política entre Girondinos e Montanheses, em maio de 1793, levou uma surra violenta de alguns membros da Sociedade das Republicanas Revolucionárias, que apoiavam os Montanheses. No século XIX, a figura de Théroigne inflamou a imaginação de historiadores como Michelet e Taine, e poetas como Baudelaire, que construíram em torno dela um mito de amazona amante de carnificina e bacante devassa. Em setembro de 1794, Théroigne foi oficialmente pronunciada louca por um funcionário de saúde da

\footnotetext{
${ }^{225}$ PALM D'AELDERS, Etta, Appel aux Françoises sur la Régénération des moeurs et necessité de l'influence des femmes dans un gouvernement libre, IN LUCAS, Colin, Editor-in-Chief The French Revolution Research Collection, University of Chicago, 1992 , The New York Public Library, microficha 9.4/32.
}

${ }^{226}$ MARAND-FOUQUET, Catherine, La femme au temps de La Révolution - 1989, Éditions Stock/Laurence Pernoud., p. 113

${ }^{227}$ idem, p. 113. 
seção Le Peletier, e internada no hospício feminino do faubourg Saint-Marceau ${ }^{228}$. Morreu em 1817 no pavilhão das dementes da prisão La Salpêtrière.

Théroigne de Méricourt e Olympe de Gouges não encontraram apoio para suas idéias em nenhum partido ou grupo político. Além do fervor revolucionário, tinham em comum nomes fabricados, e um status social dúbio. A holandesa Etta Palm se apresentava com um título duvidoso de baronesa . Nenhuma das três era casada, numa época em que a respeitabilidade da mulher dependia da condição de esposa e mãe. Gouges tinha um filho, mas havia abandonado o marido antes de vir morar em Paris. O espectro da vida galante rondava de perto essas mulheres. Numa Revolução que fazia apelos constantes à moral, as três feministas eram tipos marginais na sociedade, e não tinham credibilidade para atrair seguidoras nem das classes populares, nem da burguesia. Os homens não as levavam a sério, e alguns jornais as ridicularizavam. Nenhuma das duas conseguiu se ligar ao movimento revolucionário feminino, e sem apoio de qualquer associação organizada, elas ficaram isoladas e à mercê de todas as críticas. Não de sabe até onde as pioneiras feministas Olympe de Gouges, Pauline Léon, presidente das Republicanas Revolucionárias, e Etta Palm se conheciam ou atuaram juntas, segundo o estudo de Gary Kates ${ }^{229}$. O historiador não compartilha dessa visão de isolamento no caso de Etta-Palm d"Aelders, cujos escritos e discursos eram publicados e alcançaram milhares de ativistas influentes. A militante holandesa teve o apoio do Círculo Social (Cercle Social) junto ao qual contribuiu com panfletos para a campanha em favor do divórcio, aprovado em 1792. No outono de 1792, Etta foi considerada suspeita, e em janeiro de 1793 emigrou para a Holanda ${ }^{230}$.

\footnotetext{
${ }^{228}$ ROUDINESCO, Elisabeth, Théroigne de Méricourt, une femme mélancolique sous la Révolution. Paris, Seuil, 1989, p. 164.

${ }^{229}$ KATES, Gary, “ The Powers of Husband and Wife must be Equal and Separate’ : The Cercle social and the Rights of women, 1790-1791”. IN APPLEWHITE, Harriet B. \& LEVY Darline G. (edited by) Women \& Politics in the Age of the Democratic Revolution, Ann Arbor, The University of Michigan Press, 1993, p. 164.

${ }^{230}$ LEVY, Darline G., APPLEWHITE, Harriet B., JOHNSON, Mary D. - Women in Revolutionary Paris - 1789-1795 - . Selected documents translated with notes and commentary by the authors Urbana e Chicago, University of Illinois Press, 1980, p. 63.
} 


\subsection{0 - As leis de família}

A revolução cultural promovida pela Revolução envolvia a democratização das relações sociais em todos os níveis. Depois de destruir o poder do pai -tirano da esfera pública, seria intolerável manter a figura do pai-tirano na esfera familiar, na qual ele exercia um poder excessivo sobre os outros membros da família. A igualdade e a justiça precisavam começar pela família nuclear na base da sociedade. As leis injustas que impediam o desenvolvimento do "novo homem" - o cidadão republicano autônomo - tinham que ser varridas dos códigos. Os revolucionários empreenderam a reforma das leis civis devido ao desejo de romper com o passado monárquico e aristocrata. Queriam reformar e reabilitar a família para depois exaltá-la como o pilar fundamental do regime republicano ${ }^{231}$. A Constituição proposta em 1793 declarava que "Os pais e as mães de família são os verdadeiros cidadãos"232. A política jacobina limitou o poder da família para defender os direitos dos indivíduos. Na área da educação isso ficou claro quando a Convenção estabeleceu a obrigatoriedade de freqüência das crianças nas escolas primárias públicas (12 de dezembro de 1793), assumindo a responsabilidade para impedir abusos das famílias. Robespierre declarou " a nação tem o direito de educar suas crianças; ela não deveria confiar a tarefa ao orgulho das famílias" ${ }^{233}$.

Dentro desse espírito, as cartas régias (Lettres de cachet) foram abolidas em março de 1790, estabeleceram-se tribunais de família, e a idade da maioridade foi reduzida para vinte e um anos para ambos os sexos - antes era de trinta anos para os homens e vinte e cinco para mulheres ${ }^{234}$. Acabaram-se, pelo menos teoricamente, os casamentos forçados, o encarceramento dos filhos na Bastilha por dissipação ou

\footnotetext{
231 HUNT, Lynn, The Family Romance of the French Revolution , Los Angeles, University of California Press, 1992, p. 151.

232 GOY, Joseph "La Révolution française et la famille" In DUPAQUIER, SAUVY, LADURIE, Histoire de la population française, Paris, 1988 IN HUNT, Lynn, The Family Romance of the French Revolution, Los Angeles, University of California Press, 1992 , p. 151.

233 HUNT, Lynn, "Male Virtue and Republican Motherhood" IN BAKER, Michael K., The French Revolution and the Creation of Modern Political Culture, New York, Elsevier Science Ltd, Pergamon , 1994, vol. 4 "The Terror", p. 200.

${ }^{234}$ HUNT, Lynn "Male Virtue and Republican Motherhood" IN BAKER, Michael K., The French Revolution and the Creation of Modern Political Culture, New York, Elsevier Science Ltd, Pergamon , 1994, vol. 4 "The Terror" , pp. 198-199.
} 
rebeldia, e o enclausuramento das filhas levianas no convento. Em 3 de setembro de 1791 a lei passou a considerar o casamento apenas um contrato civil, separando o sacramento religioso, agora facultativo, do ato civil de consentimento registrado por um oficial municipal ${ }^{235}$. As leis que secularizaram o matrimônio e estabeleceram o divórcio em 20 de setembro de 1792 davam direitos iguais às mães na supervisão de seus filhos. O Estado assumiu o controle do estado civil e passou a controlar todas as questões relativas à formação e dissolução da família, substituindo-se à Igreja. O divórcio foi apresentado por seus defensores como uma conseqüência dos princípios de liberdade e igualdade, e a lei era igual para homens e mulheres. Havia várias razões para justificar o pedido de divórcio, entre elas, o consentimento mútuo, afastando qualquer idéia de culpa, o que é de uma modernidade surpreendente. Depois das limitações impostas pelo Código Civil Napoleônico de 1804 e outros retrocessos jurídicos do século XIX , a França só voltou a ter uma lei de divórcio tão liberal quanto a de 1792 em 1975. As mulheres foram as principais beneficiárias da nova lei e as autoras da maioria dos pedidos de rompimento. Dos 5.994 divórcios concedidos em Paris de 1 de janeiro de 1793 ao 29 prairial no ano III, 3.870 foram pedidos por mulheres, e 2.124 por homens ${ }^{236}$.

O direito da primogenitura e da masculinidade foi abolido em 15 de março de 1790 para os feudos. Em 1791 os herdeiros foram declarados iguais perante a lei, aumentando a autonomia das filhas, as quais agora poderiam também usufruir seus bens ao atingir a maioridade ${ }^{237}$. Os jacobinos não gostavam dos privilégios da primogenitura porque criava ricos e pobres, desrespeitando os direitos de muitos indivíduos $^{238}$, e também porque era um instituto ligado à continuidade do sobrenome da família, fazendo lembrar os odiados costumes da aristocracia. Lanthenas, membro do Círculo Social e futuro Girondino na Convenção, culpava a primogenitura pela decadência econômica e desestabilização da família, que por sua vez contribuíram para

\footnotetext{
${ }^{235}$ ROSA, Annette, Citoyennes, Paris, Messidor, 1988, pp. 122-123.

${ }^{236}$ PROCTOR, Candice E., Women, Equality and the French Revolution, chapter "The Cult of Republican Motherhood", Contribution in Women's Studies, no. 115, Greeenwood Press, p. 101. ${ }^{237}$ GODINEAU, Dominique "Les femmes et la famille' IN LUCAS, Colin, Editor-in-Chief The French Revolution Research Collection, University of Chicago, 1992 , The New York Public Library, pp. 37-39. ${ }^{238}$ HIGONNET, Patrice, Goodness beyond Virtue, Cambridge, Massachusetts e London, England,
Harvard University Press, 1998, p.85.
} 
a anarquia social do Antigo Regime ${ }^{239}$. Nas regiões onde as tradições seculares suscitaram resistência à nova lei de sucessões, as filhas, esposas e viúvas passaram a recorrer aos tribunais para exigir partes iguais nas heranças ${ }^{240}$. Em 1792, a lei reconheceu que as mulheres tinham suficiente razão e independência para serem admitidas como testemunhas nos registros civis e para contraírem livremente obrigações. Em 1793, acederam à partilha dos bens comunais.

A legislação civil progressista efetivamente deu mais autonomia e espaço para a mulher, corrigindo antigas desigualdades consagradas em lei. Dessa forma, a mulher civil adquiriu uma personalidade jurídica individual, sua posição se elevou no seio da família, e ela pode fazer valer seus direitos recém-adquiridos em novos espaços, como as instâncias judiciais. E o esforço legislativo nesse sentido continuou: em 27 de outubro de 1793 a Convenção aprovou uma lei que instituía um novo regime conjugal aplicável a todos na França, através do qual maridos e mulheres compartilhariam o direito de controlar a propriedade comum do casal ${ }^{241}$. Num dos debates acerca do assunto, dois deputados da Montanha caçoaram da idéia, ponderando que :

Merlin de Douai: "a mulher era geralmente incapaz de administrar os bens" e Thuriot: " essa lei degradaria o homem colocando-o sob a tutela da mulher". Já Danton pensava que: "nada mais natural que o marido não possa dispor dos bens sem o consentimento da mulher", Couthon: "a mulher nasce com tanta capacidade como o homem", Lacroix: "num país livre as mulheres não podem mais viver na escravidão" e Camille Desmoulins: " a supremacia conjugal do marido é uma criação de governos despóticos. E para reforçar minha opinião há também uma razão política: é importante fazer com que as mulheres amem a Revolução. Os Senhores atingirão esse objetivo agindo para que elas possam exercer seus direitos"242

239 KATES, Gary, “ The Powers of Husband and Wife must be Equal and Separate' : The Cercle social and the Rights of women, 1790-1791”. IN APPLEWHITE, Harriet B. \& LEVY Darline G. (edited by) Women \& Politics in the Age of the Democratic Revolution, Ann Arbor, The University of Michigan Press, 1993, p. 168.

240 DESAN, Suzanne, "War between Brothers and Sisters": Inheritance law and Gender Politics in Revolutionary France IN French Historical Studies, Vol. 20 , No. 4 (Autumn, 1997), pp.597-634, Duke University Press, pp. 604-605.

${ }^{241}$ HUNT, Lynn, "Male Virtue and Republican Motherhood" IN BAKER, Michael K., The French

Revolution and the Creation of Modern Political Culture, New York, Elsevier Science Ltd, Pergamon, 1994, vol. 4 "The Terror", pp. 199-200.

242 FULCHIRON, Hughes, "La femme, Mère et Épouse" IN Les Femmes et la Révolution Française Actes du colloque International, 12-13-14 avril 1989 - Université de Toulouse-le-Mirail , Toulouse, Presses Universitaires du Mirail, 1989., pp.380-381. 
Despotismo vs. direitos, liberdade vs. escravidão : a linguagem é política, mas todos sabiam que o que estava em jogo era a emancipação civil das mulheres, pela introdução de mais eqüanimidade nas relações familiares. Esse projeto de lei, entretanto, foi adiado a pedido de Thuriot e reformulado sob o Diretório, já num clima de reação jurídica à liberalidade anterior. Assim, o marido recuperou formalmente a prerrogativa de administrar sozinho os bens do casal.

Higonnet pensa que a motivação dos revolucionários ao aprovar o divórcio não foi tanto a preocupação com as mulheres, mas sim o interesse pelos princípios abstratos dos direitos naturais subtraídos dos indivíduos ${ }^{243}$. Além disso, o divórcio era uma maneira de separar casais infelizes para que pudessem se casar outra vez, formando novas famílias mais ajustadas na base da nação - ou seja, a lei de 1792 tinha o espírito do plano político de fortalecimento da sociedade. Ecoando as petições femininas no Cahiers de Doléances e manifestações de várias associações políticas, Nicolas Bonnevile disse que a indissolubilidade do casamento era contrária à boa política e prejudicial à sociedade. $^{244}$ A maioria dos revolucionários não queria mudar as relações entre os sexos, porém sua atitude em relação à família era bem diferente. Acusados de querer destruí-la, eles se defenderam com veemência: elaboraram um novo modelo familiar onde o "despotismo, os preconceitos e a religião não deviam definir os laços mais próximos da lei da natureza"245. Percebo aqui um paradoxo: como democratizar a família sem libertar a mulher da supremacia marital? Se eles escolheram o caminho da reforma civil é porque estavam dispostos a conceder mais autonomia à esposa e aos filhos, mesmo à custa de diminuir o poder masculino na família. Talvez tenham pensado que a perda individual na esfera privada seria um ganho para a sociedade como um todo.

\footnotetext{
${ }^{243}$ HIGONNET, Patrice, Goodness beyond Virtue, Cambridge, Massachusetts e London, England, Harvard University Press, 1998, p. 93.

${ }^{244}$ KATES, Gary, “ The Powers of Husband and Wife must be Equal and Separate' : The Cercle social and the Rights of women, 1790-1791". IN APPLEWHITE, Harriet B. \& LEVY Darline G. (edited by) Women \& Politics in the Age of the Democratic Revolution, Ann Arbor, The University of Michigan Press, 1993, p. 166.
}

${ }^{245}$ GODINEAU, Dominique "Les femmes et la famille' IN LUCAS, Colin, Editor-in-Chief The French Revolution Research Collection, University of Chicago, 1992 , The New York Public Library, pp. 37-39. 
Voltando ao Círculo Social, poucos de seus membros achavam que as mulheres deveriam votar e concorrer a cargos públicos. Em compensação, queriam uma integração mais igualitária da mulher na nova ordem social e fizeram uma campanha para a aprovação da lei do divórcio e leis de sucessão mais eqüitativas ${ }^{246}$. Para aqueles militantes, a mulher só obteria a igualdade cívica quando tivesse direito ao divórcio e à herança de propriedades. Para o Círculo Social, o divórcio era uma questão feminista porque o objetivo principal da igualdade política exigia esposas livres e independentes, membros do corpo político da nação, capazes de tomar decisões como os homens. Os integrantes do Círculo Social - entre os quais estavam Lanthenas, Condorcet, Etta Palm, Brissot, Bancal, Bonneville, Louis- Sébastien Mercier, Charles-Louis Rousseau, Athanase Auger, e o casal Roland - pensavam que a família igualitária era a base das instituições políticas democráticas, e para a França se tornar uma república democrática, o novo regime tinha que ser promovido pela família que devia ser um microcosmo da república: igualitária, afetuosa, voluntária e consensual $^{247}$. Nos primeiros anos da Revolução, o Círculo Social constituiu o mais significativo centro de defesa dos direitos da mulher. Apesar disso, muitos desses líderes do Círculo não defenderam tais direitos quando se tornaram deputados Girondinos na Assembléia Nacional e na Convenção, talvez porque a partir da primavera de 1792 estivessem lutando pela sobrevivência política ${ }^{248}$.

Curiosamente, até Prudhomme, um reconhecido adversário da autonomia feminina, parecia estar de acordo com o divórcio: "(...) uma lei em favor do divórcio nos desobrigará de tudo o que devemos a elas [mulheres] e provavelmente calará a boca das mais exigentes" ${ }^{249}$. Talvez assim elas não dessem o próximo passo de reivindicar os direitos políticos da cidadania. Seria o caso de entregar os anéis para não perder os dedos? Os anti-feministas conservadores enxergaram o perigo: Burke escreveu em

\footnotetext{
246 KATES, Gary, “ The Powers of Husband and Wife must be Equal and Separate' : The Cercle Social and the Rights of women, 1790-1791”. IN APPLEWHITE, Harriet B. \& LEVY Darline G. (edited by) Women \& Politics in the Age of the Democratic Revolution, Ann Arbor, The University of Michigan Press, 1993, pp. 166-167.

247 idem, p. $175-176$.

248 ibidem, p. 177.

${ }^{249}$ PROCTOR, Candice E., Women, Equality and the French Revolution, chapter "The Cult of Republican Motherhood", Contribution in Women's Studies, no. 115, Greeenwood Press, p. 105.
} 
1796 que a Revolução instituiu "o mais licencioso, o mais depravado (...) mais feroz sistema de costumes" pois libertou as mulheres com as novas leis civis instaurando uma "igualdade ignóbil" que até as prostitutas londrinas achariam vergonhoso ${ }^{250}$. Quem escolhia marido e pedia o divórcio, podia se arrogar o direito de escolher o governo. Os redatores do Código Civil em 1804 também culparam a Revolução por ter criado maus hábitos e desordem nos costumes femininos ${ }^{251}$, para justificar a restauração da supremacia conjugal do marido. Estavam certos: elas não mais se conformavam em obedecer passivamente, eram cidadãs, tinham direitos, expressavam opiniões. A Revolução criou expectativas de igualdade cívica e algumas mulheres queriam participação política na vida nacional. Mas, as esperanças duraram pouco: na reação conservadora termidoriana, e mais ainda, no Código Civil napoleônico, a maioria das disposições progressistas foram anuladas ou esvaziadas do sentido original. Não obstante, no curto período de sua vigência , as leis civis revolucionárias criaram condições para a emergência da mulher juridicamente capaz, atuando em espaços novos com maior liberdade. A mulher civil emprestou maior peso às pretensões políticas das ativistas.

\subsection{1 - A militância organizada}

Em 1790, a Sta. Jodin, filha de um cidadão de Genebra, escreveu uma proposta à Assembléia Constituinte reivindicando o estabelecimento de um tribunal judiciário exclusivo para as mulheres. Ela fala a linguagem política da regeneração do Estado pela virtude e boas leis e clama:

pensei que meu sexo, que compõe a metade interessante deste belo Império, podia também reclamar a honra e mesmo o direito de concorrer à prosperidade pública; e que rompendo o silêncio ao qual a política parece nos haver condenado, possamos dizer: E nós também, nós somos cidadãs ${ }^{252}$. ("et nous aussi, nous sommes citoyennes”)

\footnotetext{
${ }^{250}$ GUIBERT-SLEDZIEWSKI, Elizabeth , “Revolução Francesa. A viragem” IN DUBY, Georges e PERROT, Michelle (direção da coleção) e FRAISSE, Geneviève e PERROT, Michelle (direção do volume 4) História das Mulheres no Ocidente, vol. 4, Do Renascimento à Idade Moderna (trad.) Porto, Ed. Afrontamento, 1994, pp.43-44.

251 idem, p. 46.

252 Mlle. JODIN , « Vues Législatives pour les Femmes » IN Cahiers de doléances des femmes en
} 1789 et autres textes - préfacé par Paule-Marie Duhet - Paris, C. Des femmes 1981, p.183. 
Esta frase ficou famosa porque adquiriu um sentido concreto através das práticas das ativistas na Revolução. As militantes se julgavam incluídas na categoria homem, na acepção de humanidade, da Declaração dos Direitos do Homem e do Cidadão. Leopold Lacour ${ }^{253}$ observou que na Declaração ... "homem significava "homo" (no sentido de todos os seres humanos) e não "vir" (sexo masculino) ”. Mas na verdade, o governo jacobino interpretou o significado de homem segundo suas conveniências: quando se tratava de impostos e leis penais, a categoria homem incluía as mulheres (sentido homo, todos) , porém se a questão fossem os direitos políticos, educacionais e sociais, homem adquiria o sentido mais restrito de masculino ( sentido vir, só o sexo masculino). As ativistas queriam fazer parte do povo soberano, e passaram a se auto-intitular cidadãs (citoyennes), usando a palavra não mais como esposas e filhas de cidadãos, mas em sua acepção política, de pertencimento à cidade e ao conjunto da nação, com todas as prerrogativas inerentes ao termo. Isso significava trabalhar pelo bem público ${ }^{254}$. Como disse a Sta. Jodin, ela queria ter a honra e o direito de “contribuir à prosperidade pública”. Na República, ser cidadão era um título que conferia honra ao seu portador. Poucas cidadãs reivindicaram o voto, mas a maioria achava que a cidadania implicava alguma participação na vida nacional. Assim, para prestar uma colaboração mais eficaz nas circunstâncias revolucionárias, as mulheres começaram a se organizar em clubes filantrópicos. A época das vozes feministas isoladas tinha passado.

\section{$\underline{11.1}$ - Clubes femininos nas províncias}

Entre 1789 e 1791 formaram-se em Paris e nas províncias as primeiras associações mistas ou femininas, que, substituindo-se às antigas congregações religiosas, dedicavam-se principalmente a ajudar os necessitados ${ }^{255}$. Os clubes organizados de mulheres tinham um regulamento, uma presidente, secretárias e escritórios. Raramente tinham mais de sessenta membros, mas o de Dijon tinha quatrocentos . No início elas eram integradas por burguesas aparentadas com as

\footnotetext{
${ }^{253}$ BLUM, Carol, Rousseau and the Republic of Virtue - The language of Politics in the French Revolution, Ithaca and London, Cornell University Press, 1986 , p. 208 - na mesma página, citação da obra do historiador Léopold Lacour, Trois Femmes de la Révolution. Paris, Plon, 1900.

254 GODINEAU, Dominique, Citoyennes Tricoteuses - Les femmes du peuple à Paris pendant la Révolution Française, Paris, Editions Alinea, Perrin, 2004 , p. 112-113.

${ }_{255}$ GODINEAU, Dominique, Citoyennes Tricoteuses - Les femmes du peuple à Paris pendant la
} Révolution Française, Paris, Editions Alinea, Perrin, 1988, 2004 , p. 113-115. 
autoridades locais, mas aos poucos se democratizaram, respondendo aos novos desafios de forma criativa conforme o desenrolar da Revolução. Dominique Godineau (1988) apresenta uma lista não exaustiva de 30 cidades na França onde havia um clube feminino ou misto, e um mapa de sua localização ${ }^{256}$. Nota-se uma ausência de clubes no Oeste, região da Vendéia, Bretanha, Normandia, onde a única agremiação é a das monarquistas, justamente na região que foi palco da guerra civil contra-revolucionária. Já Suzanne Desan, em trabalho mais recente (2002) recenseou clubes femininos em 56 cidades, e a lista não inclui clubes femininos monarquistas nem "sociedades fraternas dos dois sexos" ${ }^{257}$. As atividades assistenciais tradicionais asseguravam a aceitação social desses grupos, que assim tinham oportunidade de se reunir e começar a se interessar pela vida política. Durante as sessões, as mulheres cuidavam da benemerência, liam e discutiam a Declaração de Direitos do Homem e do Cidadão, decretos da Assembléia e jornais ${ }^{258}$. Algumas associações, entretanto, se atinham à caridade e práticas de uma "cidadania ornamental", por assim dizer. Vejamos as atividades propostas no discurso do cidadão Sobry, presidente da Associação das Cidadãs de Lyon dedicadas à Pátria e à Lei ${ }^{259}$, em 16 de agosto de 1791:

a associação das nossas mulheres só deve comportar, quanto aos sentimentos, um voto constante de patriotismo, e quanto às práticas, apenas cerimônias e obras de beneficência e de religião (...) as mulheres e moças de bons costumes (moeurs) formarão a base da associação das cidadãs de Lyon dedicadas à pátria (...) elas farão as honras das pompas cívicas, dos triunfos, marchas magistrais, júbilos patrióticos (...) coroas de flores, (...) ou de louros, ou de ouro caracterizarão sobre a cabeça de nossas mulheres dedicadas, cada uma das diferentes solenidades.

Esse foi um caso sui generis de entidade feminina presidida por um casal, o Cidadão Sobry e sua mulher, Femme Sobry, e secretariada por três membros

\footnotetext{
${ }^{256}$ GODINEAU, Dominique, Citoyennes Tricoteuses - Les femmes du peuple à Paris pendant la Révolution Française, Paris, Editions Alinea, Perrin, 1988, 2004, p. 114.

257 DESAN, Suzanne - “Constitutional Amazons: Jacobin Women’s Clubs in the French Revolution” IN Re-creating Authority in Revolutionary France, edited by Bryant T. Ragan, Jr.and Elizabeth A. Williams, New Brunswick, New Jersey, Rutgers University Press, 1992, p. 178, nota 4.

258 GODINEAU, Dominique, Citoyennes Tricoteuses - Les femmes du peuple à Paris pendant la Révolution Française, Paris, Editions Alinea, Perrin, $2004,115$.

${ }^{259}$ Institution des citoyennes de Lyon dévouées à la patrie, et Règlement de l'Association des citoyennes dévouées à la patrie, 1 octobre 1791, microficha 9.4/42, 1791 IN LUCAS, Colin, Editorin-Chief The French Revolution Research Collection, University of Chicago, 1992, The New York Public Library.
} 
masculinos. O objetivo da presença masculina era "inspirar respeito" ${ }^{260}$, suponho que entre as mulheres, e também garantir a seriedade do clube perante a sociedade. O programa de ação reflete o papel que se esperava das mulheres na nova ordem social.

Outros clubes de província seguem a mesma linha de ação. O clube feminino de Bordeaux reuniu três mil e quinhentas mulheres que participaram de uma cerimônia de juramento patriótico em 1791, todas enfeitadas com as cores nacionais, carregando bandeiras e gritando "viva a nação, viva a liberdade"261. Em Grenoble, Lille e Cognac os clubes femininos organizaram vários festivais para celebrar a unidade nacional, a constituição, cerimônias fúnebres para homenagear Le Peletier e Marat, e bailes de despedida para os voluntários da nação. Nessas ocasiões festivas, as mulheres presenteavam os soldados com coroas cívicas, e declaravam que só dariam seu afeto aos heróis patriotas. A iconografia registrou muitas cenas de "cidadania ornamental" por parte das mulheres e também reuniões de clubes femininos; no caderno de imagens desta dissertação há exemplos de visões positivas e negativas O clube de Dijon organizou oficinas onde as mulheres pobres trabalhavam na produção de roupas, bandagens e cobertores para o exército. O ataque à Igreja e fechamento dos conventos desorganizou a educação, o socorro aos desvalidos e os cuidados aos doentes, e abriu um campo de ação para as mulheres leigas, as quais assumiram tarefas antes realizadas por freiras ${ }^{262}$. Os jacobinos aprovavam a participação das patriotas em papéis tradicionalmente femininos - elas podiam enfeitar as festas com sua beleza, encorajar os voluntários, ensinar crianças, inspirar os fracos, organizar doações - e muitas doaram suas jóias e pertences ao governo. Mas tinham que tomar cuidado para não ultrapassar os limites estabelecidos para seu sexo , como fica claro nesta declaração de um revolucionário: "as mulheres (...) mantêm o fogo sagrado da liberdade nos corações de nossos jovens republicanos(...) Enquanto mãos viris se ocupam com labores rústicos, vemos as republicanas usando suas mãos delicadas para

\footnotetext{
${ }^{260}$ DESAN, Suzanne - "Constitutional Amazons: Jacobin Women’s Clubs in the French Revolution” IN Re-creating Authority in Revolutionary France, edited by Bryant T. Ragan, Jr.and Elizabeth A. Williams, New Brunswick, New Jersey, Rutgers University Press, 1992, nota 12, p. 179

${ }^{261}$ DESAN, Suzanne - “Constitutional Amazons: Jacobin Women’s Clubs in the French Revolution” IN Re-creating Authority in Revolutionary France, edited by Bryant T. Ragan, Jr.and Elizabeth A. Williams, New Brunswick, New Jersey, Rutgers University Press, 1992, pp. 13-14.

262 idem, p. 19.
} 
LES CLUBS DE FEMMES ET LES SOCIETES POPULAIRES MIXTES

$(1789-1793)$

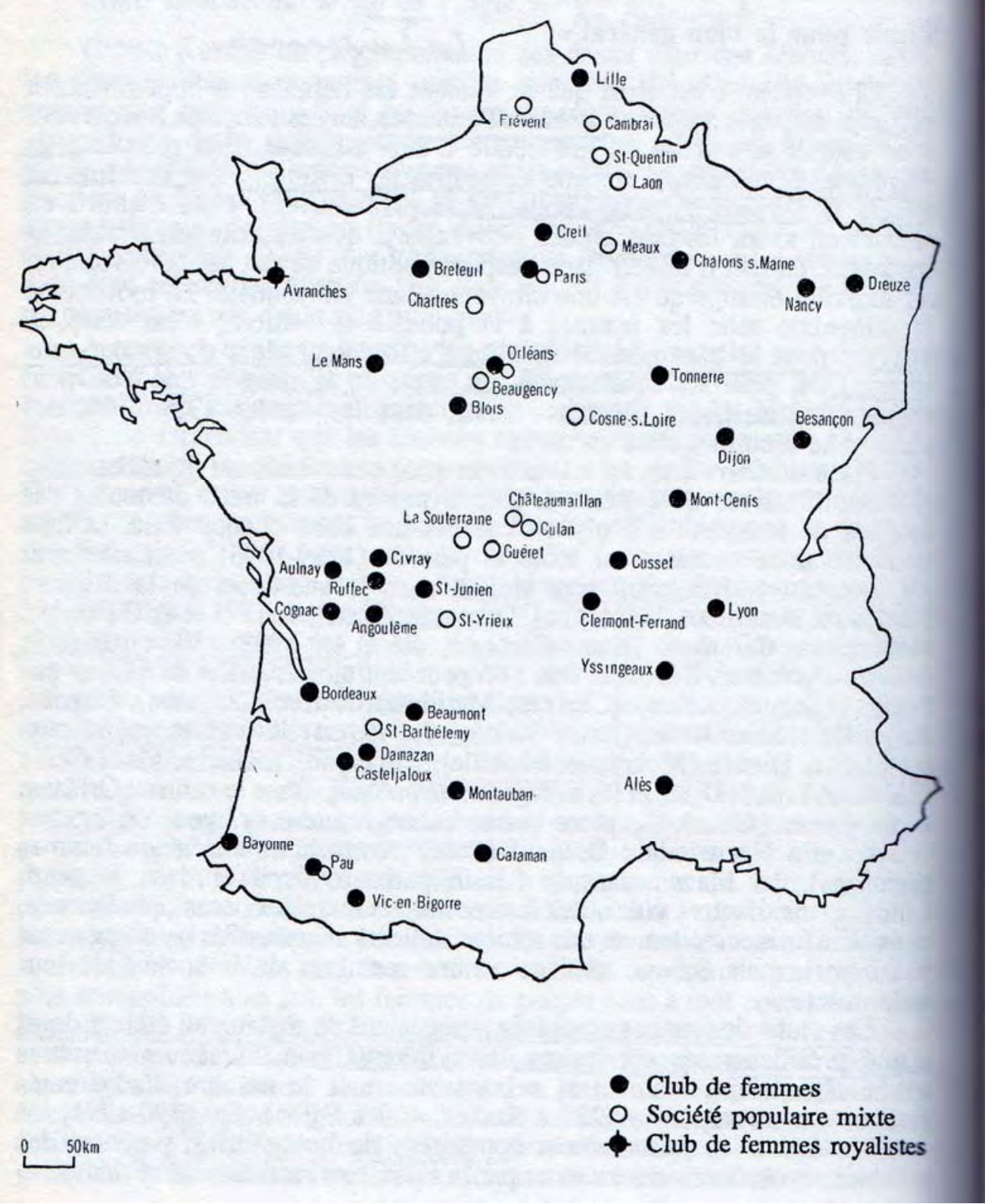

Os Clubes das Mulheres e Sociedades Populares Mistas.

263 GODINEAU, Dominique, Citoyennes Tricoteuses - Les femmes du peuple à Paris pendant la Révolution Française, Paris, Editions Alinea, Perrin, 2004 , p. 114. 
tarefas que lhes são apropriadas: preparam bandagens para estancar um sangue precioso $(. . .)^{1264}$.

Como apontou o estudo de Suzane Desan, vários clubes políticos masculinos apoiavam a formação de associações femininas, e em 1792, os Representantes em Missão fomentavam a criação dessas entidades na Provence. O jornalista Carra incentivava e elogiava os clubes femininos, e em 1791 declarou que havia chegado o reino da razão também para as mulheres. Argumentava que os clubes facilitavam seu

duplo papel: consolar e alegrar a vida dos homens e contribuir para o progresso da virtude e prosperidade social. ${ }^{265}$

As relações entre clubes masculinos e femininos eram, em geral, cordiais, mas hierárquicas: funcionavam melhor quando os homens ensinavam às mulheres os princípios da Revolução. Porém, a combinação da atuação feminina no âmbito privado e no público muitas vezes era recebida com ambivalência, caçoadas ou ataques dos revolucionários. O clube feminino de Besançon teve um conflito aberto com o clube jacobino masculino da cidade, que acusou as ativistas pelo jornal Vedette de protagonizarem "cenas escandalosas na Société des Amies" porque os homens podiam vir às suas oficinas de trabalho ${ }^{266}$. As críticas masculinas às sociedades femininas diziam respeito à moralidade, desordem e "irracionalidade", ou seja, "à natureza feminina" ou o caráter dos membros, e não à atividade objetiva. A autonomia feminina incomodava e podia levar à "inversão de papéis" e o conseqüente caos social.

\footnotetext{
${ }^{264}$ AULARD, F.A., Recueil des Actes du comité de Salut Public, vo. 9, pp. 361-362 IN PROCTOR, Candice E., Women, Equality and the French Revolution, chapter "The Cult of Republican Motherhood", Contribution in Women's Studies, no. 115, Greeenwood Press, pp. 63-64.

${ }^{265}$ DESAN, Suzanne - "Constitutional Amazons: Jacobin Women’s Clubs in the French Revolution” IN Re-creating Authority in Revolutionary France, edited by Bryant T. Ragan, Jr.and Elizabeth A. Williams, New Brunswick, New Jersey, Rutgers University Press, 1992, p. 20.

${ }^{266}$ DESAN, Suzanne - "Constitutional Amazons: Jacobin Women’s Clubs in the French Revolution” IN Re-creating Authority in Revolutionary France, edited by Bryant T. Ragan, Jr.and Elizabeth A. Williams, New Brunswick, New Jersey, Rutgers University Press, 1992 p. 15., e p/clube de Besançon, pp. 11-12.
} 
Prudomme, crítico acerbo da participação feminina na política, escreveu no seu jornal Révolutions de Paris em 25 de janeiro de 1793, antes, portanto da proibição das associações femininas:

Nada seria mais edificante e útil que se formasse um círculo de boas mães de família do mesmo bairro para, com seus filhos no colo, costurarem e se consultarem reciprocamente sobre

os deveres de seu estado [a maternidade] e que um cidadão, pai de família, viesse informarlhes sobre novas leis da Assembléia que lhes dissessem respeito (...) Mas o que pensar sobre o

clube de mulheres que acaba de abrir suas portas em Lyon? Porque ter uma presidenta e sessões de acordo com o regulamento? Registro das atas das reuniões? O hino à Liberdade é compreensível, mas porque convidar autoridades do distrito e da municipalidade para assistir às sessões? E convidar o bispo l'Amourette para lhes trazerem o catecismo mais atualizado? E o que passa pela cabeça das lionesas de ensinar às jovens cidadãs o Contrato Social de J.J.

Rousseau? Imploramos às boas cidadãs de Lyon que fiquem em casa, cuidando da casa (....) sem ter a pretensão de entender o Contrato Social

Se as mulheres de todas as cidades e aldeias da França as imitarem, haverá clubes em toda parte, e nenhuma casa bem cuidada. ( Aviso às mulheres que estão formando um clube na cidade de Dijon) ${ }^{267}$.

As respostas não se fizeram esperar, e o jornal publicou-as no número 189, de fevereiro. A Sra. Charton, presidente do clube de Lyon declarou:

Em número anterior do jornal, propuseste que as cidadãs se reunissem para formar em seus filhos o espírito público, citando para eles o exemplo das cidadãs de Roma; o objetivo de nossa associação é de instruir-nos acerca dos decretos da Convenção lendo o seu jornal, socorrer os irmãos infelizes e instruir as crianças sobre a nova ordem das coisas e jurar ódio eterno aos tiranos. As cidadãs só se reúnem aos domingos (...) para recompensar as crianças mais aplicadas nos estudos; apenas nesses dias convidam as autoridades (...)

E a presidente da Sociedade das amigas da República de Dijon, a cidadã Blandin-Demoulin, respondeu: " Nós não nos limitamos, cidadão Prudomme, a cantar hinos à Liberdade, como nos aconselha; queremos realizar atos de civismo (...) segundo parece, achas (tu) que saber ler é inútil para uma mulher, e os clubes femininos são um flagelo da moral doméstica" . Ela argumenta que uma mãe ignorante deixa seus filhos morrerem de doenças, e que o cultivo das ciências não atrapalha o trabalho. "Renuncie portanto ao vosso sistema despótico em relação às mulheres como a aristocracia em relação ao povo - qual é a virtude que se pode esperar de um escravo?"

${ }^{267}$ PRUDOMME, Révolutions de Paris, no. 185, 19 a 16 de janeiro de 1793 IN LUCAS, Colin, Editor-in-Chief The French Revolution Research Collection, University of Chicago, 1992, The New York Public Library, microficha no. 9.4/46. 
Por sua vez, Prudomme replicou dizendo que elas não deveriam ter a pretensão de ser melhores que as mulheres de Esparta e Roma ${ }^{268}$.

O que surpreende não é o anti-feminismo de Prudomme e outros jacobinos. É a existência de sessenta associações femininas ativas em toda a França, atestando a dimensão da prática política das francesas. Quando Camille Desmoulins disse que era preciso que as mulheres "amassem a Revolução" e para isso tinham que exercer seus direitos, ele se referia às leis de família. Porém, creio que alguns líderes perceberam que a energia e o entusiasmo das mulheres podiam ajudar a causa revolucionária . O governo incentivou a criação desses clubes na Provence porque precisava da ajuda dessa rede de sociedades de mulheres para educar crianças, cuidar dos doentes nos hospitais, ajudar as viúvas de guerra, fabricar roupas, cobertores e bandagens para os soldados na guerra e manter vivo o espírito republicano com seus desfiles, coroas cívicas, hinos e cerimônias. Os clubes masculinos de Bordeaux homenagearam várias vezes as mulheres por suas doações patrióticas, e em Dijon e Besançon apoiaram os esforços das mulheres para estabelecer escolas ${ }^{269}$. Com sua presença ativa elas se fizeram indispensáveis e ocuparam o espaço social e político que a Revolução criara. As leis civis que beneficiaram as mulheres certamente as tornaram mais aptas para o exercício da cidadania. Elas adquiriram experiência na direção de reuniões, debates, petições, mantinham relações com os clubes masculinos, que por sua vez as orientavam e enviavam oradores - mas elas administravam seus próprios clubes. As presidentes dos clubes de Lyon e Dijon agiam como cidadãs, e falavam a linguagem política da Revolução - era impossível distanciar-se dela. . O sentido que visavam com sua prática nos clubes era contribuir para a coisa pública, e para isso precisavam aperfeiçoar seus conhecimentos de princípios e leis revolucionárias. Muitos homens, entretanto, eram reticentes ou hostis à atuação das associações femininas quando suas atividades ultrapassavam a filantropia para entrar no terreno político - e masculino de facto. Ironicamente, todos se justificavam com os argumentos de Rousseau, fazendo leituras diferentes de suas idéias: as mulheres enxergavam a exaltação das mães e a responsabilidade pela formação dos bons

${ }^{268}$ PRUDOMME, Révolutions de Paris, no. 189, 16 a 23 de fevereiro de 1793 IN LUCAS, Colin, Editor-in-Chief The French Revolution Research Collection, University of Chicago, 1992, The New York Public Library, microficha no. 9.4/46.

${ }^{269}$ DESAN, Suzanne - "Constitutional Amazons: Jacobin Women's Clubs in the French Revolution” IN Re-creating Authority in Revolutionary France, edited by Bryant T. Ragan, Jr.and Elizabeth A. Williams, New Brunswick, New Jersey, Rutgers University Press, 1992 , p. 19. 
costumes; os homens notavam a demarcação sexual dos papéis e a domesticidade feminina. A questão dos direitos de cidade das mulheres exigia atenção.

\subsection{2 - $\underline{\text { O direito às armas }}$}

Em 27 de abril de 1791, Robespierre justificou a exclusão dos cidadãos passivos da Guarda Nacional : “Armar-se para a defesa pessoal é direito de todo homem indistintamente; armar-se para a defesa da pátria é direito de todo cidadão”270.

Em 1792 a idéia de um regime republicano inflamava o movimento popular, justificado pela fuga do Rei e massacre do Campo de Marte no ano anterior, e pela crise constitucional aberta quando Luís XVI, dois meses depois de declarar guerra à Áustria, demitiu o ministério Girondino e vetou decretos considerados vitais para a segurança da nação ${ }^{271}$. Os sans-culottes emergiram na cena pública e radicalizaram as ações populares, forçando uma redefinição de soberania como a vontade e o poder do povo. A Constituição de 1791 negou direitos de cidadania às mulheres, mas as tensões revolucionárias levaram-nas a criar todo um repertório de ações políticas e militares ${ }^{272}$. O avanço da Revolução, principalmente depois da abolição da monarquia, desfez a distinção entre cidadãos ativos e passivos, que excluía os pobres. As Seções parisienses aos poucos rejeitaram tal separação, e permitiram aos passivos ingressarem na Guarda Nacional e votarem nas assembléias gerais ${ }^{273}$. As mulheres se queriam citoyennes, eram chamadas de citoyennes e aproveitaram esse período de redefinição da cidadania para afirmar seus direitos integrando-se na luta política ao lado dos homens.

Poucas ativistas pediram explicitamente o direito ao voto; um número mais expressivo levantou a bandeira do direito às armas. Pauline León, militante de vinte e quatro anos, fez a primeira manifestação pública nesse sentido. Em 6 de março

270 GODINEAU, Dominique, Citoyennes Tricoteuses - Les femmes du peuple à Paris pendant la Révolution Française, Paris, Editions Alinea, Perrin, 2004, p.119.

${ }^{271}$ MELZER, Sara E. And RABINE, Leslie W. (editoras), Rebel Daughters -Women and the French Revolution, New York - Oxford, Oxford University Press, 1992, p. 91.

${ }^{272}$ LEVY, Darline Gay e APPLEWHITE, Harriet B., "Women, Radicalization, and the Fall of the French Monarchy” IN APPLEWHITE, Harriet B. \& LEVY Darline G. (edited by) Women \& Politics in the Age of the Democratic Revolution, Ann Arbor, The University of Michigan Press, 1993, p. 82. ${ }^{273}$ GODINEAU, Dominique, Citoyennes Tricoteuses - Les femmes du peuple à Paris pendant la Révolution Française, Paris, Editions Alinea, Perrin, 2004 , p. 118. 
de 1792, a jovem, à frente de uma deputação de cidadãs, leu na Assembléia Legislativa uma petição assinada por 320 mulheres pedindo permissão para organizar uma Guarda Nacional feminina. Dentre as signatárias, vinte nomes formariam o núcleo da Sociedade das Republicanas Revolucionárias fundada um ano depois pela oradora e Claire Lacombe. As peticionárias, afirmando-se cidadãs porque parentes de homens livres, reclamaram um dos atributos da cidadania em nome do direito natural, "que todo indivíduo tem de cuidar da defesa da própria vida e de sua liberdade, além do direito de resistência à opressão"274. A menção da inclusão feminina na Declaração era um desafio à coerência da legislação vigente:

Sim senhores, é de armas que precisamos (...) não creiam que nosso desígnio seja abandonar os cuidados de nossa família e nosso lar para correr ao encontro do inimigo (...) os senhores não podem nos recusar esse direito que a natureza nos dá, a menos que se pretenda que a Declaração dos Direitos não se aplica às mulheres e que elas têm que se deixar degolar como cordeiros, sem o direito de se defender? alguém acredita que os tiranos nos pouparão? Não, não: : eles se lembrarão dos dias 5 e 6 de outubro de 1789 (...) nós que juramos viver livres ou morrer, não consentiremos jamais em dar à luz a escravos, preferimos morrer; manteremos nosso juramento (...) mostraremos aos tiranos que as mulheres também têm sangue para derramar no serviço da pátria em perigo ${ }^{275}$.

Pauline León queria permissão para conseguir armas, (piques, pistolas e sabres e rifles ) segundo o estipulado pelo regulamento da polícia; permissão para treinamento no Campo da Federação comandadas pelos antigos Guardas Franceses, dentro das normas da ordem pública. Pauline fez questão de frisar o respeito à ordem e aos regulamentos vigentes, e teve o cuidado se colocar sob a chefia masculina dos Guardas Franceses, mantendo assim a hierarquia dos gêneros. A militante alegou que as mulheres também possuíam os atributos políticos e morais da cidadania, como o vivo interesse pelo destino da nação. E renovou o juramento de "viver livres ou morrer". Quanto ao espírito cívico, já havia sido demonstrado na Marcha a Versalhes, pelo que seriam lembradas pelos "tiranos e inimigos" . Elas corriam risco de represália. O sentido do discurso de Pauline Léon era fazer ver aos deputados que as militantes estavam preparadas para assumir todas as responsabilidades da cidadania, porque já as praticavam, e reivindicar as prerrogativas devidas a todos os cidadãos. Penso que o argumento - pertinente - da possível vingança dos "tiranos e inimigos" realçava o

\footnotetext{
${ }^{274}$ GODINEAU, Dominique, Citoyennes Tricoteuses - Les femmes du peuple à Paris pendant la Révolution Française, Paris, Editions Alinea, Perrin, 2004 , p. 119.

${ }^{275}$ "Nous voulons pouvoir défendre notre vie" Adresse individuelle à l'Assemblée Nationale par des Citoyennes de la Capitale - 6 de março 1791 - Cahiers de doléances des femmes en 1789 et autres textes - préfacé par Paule-Marie Duhet - Paris, C. Des femmes 1981, pp.169-172.
} 
caráter público de sua ação política e militar revolucionária. Elas tinham lutado como cidadãs, precisavam de armas como cidadãs para defesa própria e da pátria. Assim, o pedido de formação de uma Guarda Nacional feminina pode ser interpretado como uma reivindicação dos direitos de cidade.

Um deputado ponderou que o pedido inverteria a ordem da natureza, e que as mãos delicadas das mulheres não foram feitas para manusear lanças homicidas. A Assembléia foi inconclusiva a respeito da petição, não querendo expressamente proibir nem concordar com a idéia da militância armada. Então, depois de mandar imprimir a petição e fazer uma menção honrosa em ata, os deputados passaram à ordem do dia. Um jornalista conservador, Montjoie, alertou para o perigo de as mulheres interpretarem essa indefinição como permissão para se armarem $^{276}$. De fato, a ambigüidade favoreceu as mulheres. Dominique Godineau assinala que essa petição do porte de armas marca “oficialmente” o surgimento das "tricoteiras" (tricoteuses) parisienses. Não é coincidência que o primeiro ato público do grupo tenha sido a reivindicação de armas, evocando lutas e violência, duas circunstâncias que pertenciam ao universo masculino. Mais tarde, a palavra tricoteuses evocará ódios, medos e fantasmas ligados à violência feminina ${ }^{277}$. Penso que essas mulheres não queriam "trocar de lugar" com os homens, mas participar como cidadãs iguais na defesa da pátria. Os deputados, entretanto, alegaram a imperiosa diferenciação dos sexos "as mãos delicadas das mulheres..." para , na prática, recusar a idéia. Mas a transgressão ia além da subversão dos papéis sexuais: as armas eram o braço violento do movimento popular, e podiam ameaçar o poder constituído. Por último, e não menos importante, a concessão das armas levaria eventualmente à colocação dos direitos políticos femininos na ordem do dia.

Poucos dias depois de Pauline León, em 25 de março, Théroigne de Méricourt fez um discurso ainda mais radical na Société Fraternelle des Minimes, no qual não só defendia o direito às armas, mas denunciava a opressão social das francesas:

\footnotetext{
${ }^{276}$ LEVY, Darline Gay e APPLEWHITE, Harriet B., "Women, Radicalization, and the Fall of the French Monarchy” IN APPLEWHITE, Harriet B. \& LEVY Darline G. (edited by) Women \& Politics in the Age of the Democratic Revolution, Ann Arbor, The University of Michigan Press, 1993, p. 89. 277 GODINEAU, Dominique, Citoyennes Tricoteuses - Les femmes du peuple à Paris pendant la Révolution Française, Paris, Editions Alinea, Perrin, 2004 , p. 119.
} 
Nós nos armaremos, porque é razoável que estejamos preparadas para defender nossos direitos, nossos lares (...) mostremos aos homens que não lhes somos inferiores nem em virtude nem em coragem; mostremos à Europa que as Francesas conhecem seus direitos e estão à altura das luzes do século dezoito. Desprezemos os preconceitos absurdos (...) Comparem o que somos com o que deveríamos ser na ordem social. (grifo meu) Francesas, eu vos digo mais uma vez, elevemo-nos à altura de nossos destinos; rompamos nossas correntes; é chegada a hora de as mulheres saírem de sua nulidade vergonhosa,(grifo meu) onde a ignorância e a injustiça dos homens as sujeitam - façamos como as Gaulesas e as orgulhosas Germânicas que deliberavam nas assembléias públicas e combatiam ao lado de seus esposos para repelir os inimigos da Liberdade ${ }^{278}$.

Quatro meses mais tarde, oitenta cidadãs da Seção Hôtel-de-Ville pediram à Assembléia Legislativa para decretar que "as verdadeiras cidadãs " deviam se armar ${ }^{279}$. Nas províncias, também houve exemplos de mulheres que queriam lutar. Os membros do clube feminino de Dijon declararam: "as mulheres livres que amam a pátria sabem como (...) fazer os sacrifícios que os perigos da pátria exigem" ${ }^{280}$. Em Vire, quando um orador jacobino sugeriu que as mulheres ricas pagassem os soldos da Guarda Nacional, uma espectadora respondeu que elas estavam dispostas a montar guarda pessoalmente, uma vez admitidas como membros dos clubes; em Eguilles, o marselhês jacobino Monbrion organizou uma companhia armada de mulheres na Guarda Nacional local ${ }^{281}$.

Tantas manifestações devem ter assustado o jornalista Prudomme, que escreveu um artigo em fevereiro de 1792 assinalando a importância simbólica e militar da pique (lança popular) , uma arma produzida em grandes quantidades nas Seções de Paris pela população alarmada com a guerra: "universalmente acessível até para o mais pobre cidadão, símbolo de independência, igualdade nas armas, vigilância e recuperação da liberdade (...) aterrorizante para pessoas malévolas (...)" cada cidadão deveria possuir duas "uma para defender sua casa , outra para a segurança da República". Desprezando o que ele descreveu como "projeto de Théroigne de Méricourt" para organizar e liderar uma falange de Amazonas - apesar de o discurso dela ser posterior ao número do

\footnotetext{
${ }^{278}$ MÉRICOURT, Théroigne - Discours prononcé à la Societé Fraternelles des Minimes, le 25 mars 1792, l'an quatrieme de la liberté, en présentant un Drapeau aux Citoyennes du Faubourg S. Antoine - IN LUCAS, Colin, Editor-in-Chief The French Revolution Research Collection, University of Chicago, 1992, The New York Public Library., microficha no. 9.4/50

${ }^{279}$ GODINEAU, Dominique, Citoyennes Tricoteuses - Les femmes du peuple à Paris pendant la Révolution Française, Paris, Editions Alinea, Perrin, 2004 , p.119.

${ }^{280}$ DESAN, Suzanne - "Constitutional Amazons: Jacobin Women’s Clubs in the French Revolution” IN

Re-creating Authority in Revolutionary France, edited by Bryant T. Ragan, Jr.and Elizabeth A. Williams, New Brunswick, New Jersey, Rutgers University Press, 1992 , p. 27.

${ }^{281}$ HIGONNET, Patrice, Goodness beyond Virtue, Cambridge, Massachusetts e London, England, Harvard University Press, 1998, p. 93.
} 
jornal Révolutions de Paris - declarou: "As piques devem ser proibidas para as mulheres; vestidas de branco e cingidas com a faixa nacional, elas devem se contentar em ser simples espectadoras" ${ }^{282}$. Decididamente, Prudohomme preferia a cidadania ornamental para as mulheres.

Com ou sem permissão, as militantes participaram de uma série de procissões armadas na primavera e verão de 1792 (de abril a junho). As mulheres sans-culottes das Seções de Paris e algumas burguesas estiveram no centro das agitações que levaram à queda da monarquia e instauração da República. Os líderes revolucionários incentivaram ou até programaram a participação feminina nas seis marchas insurrecionais para mostrar o poder da nação armada, a legitimidade da vontade popular e a soberania da nação. Na prática, o "recrutamento político" das ativistas por líderes revolucionários dissolvia a distinção entre cidadãos ativos e passivos e subvertia os modelos rousseauístas de comportamentos dos gêneros ${ }^{283}$. Assim, as aspirações das mulheres no contexto da luta popular, o esmaecimento da distinção entre cidadãos ativos e passivos, a tolerância e até incentivo por parte de alguns líderes jacobinos, ajudaram a forjar o nascente conceito de cidadania feminina.

Sinal de que alguns jacobinos perceberam a relevância da participação feminina no movimento popular, a Comuna de Paris e o Prefeito Jérome Pétion resolveram homenagear as militantes publicamente, apontando-as como exemplos de cidadania feminina. Pétion discursou apoiando uma petição em favor de Reine Audu, uma das poucas integrantes da Marcha a Versalhes a ir para a prisão. Observou que quando a pátria corria perigo, as mulheres não se sentiam menos cidadãs (que os homens) e reconheceu que "nós não estamos suficientemente sensibilizados para a importância de formar cidadãs". Elogiou Reine Audu, " você mostrou grande energia e prestou importantes serviços". O Conselho da Comuna decretou uma cerimônia para o Prefeito oferecer "a esta citoyenne uma espada como testemunho autêntico de sua

\footnotetext{
${ }^{282}$ PRUDOMME , "Des Piques", Révolutions de Paris, 11-18 fevereiro IN LEVY, Darline Gay e APPLEWHITE, Harriet B., "Women, Radicalization, and the Fall of the French Monarchy" IN APPLEWHITE, Harriet B. \& LEVY Darline G. (edited by) Women \& Politics in the Age of the Democratic Revolution, Ann Arbor, The University of Michigan Press, 1993, pp. 88-89. 283 LEVY, Darline Gay e APPLEWHITE, Harriet B. - "Women and Militant Citizenship in Revolutionary Paris" I N MELZER, Sara e RABINE, Leslie W. (editoras), Rebel Daughters -Women and the French Revolution, New York - Oxford, Oxford University Press, 1992, p. 91-92.
} 
bravura e patriotismo" ${ }^{284}$. Assim como Hérault de Séchelles, em agosto de 1793, homenageou coletivamente as participantes da Marcha a Versalhes (assunto discutido no item Repercussões da Marcha), Pétion e o Conselho da Comuna também elegeram uma daquelas ativistas como exemplo de patriotismo. É interessante notar que quando os líderes revolucionários queriam homenagear as cidadãs francesas e militantes intrépidas, lembravam-se das heroínas de outubro, atestando a importância de seu papel no início da Revolução e a forte impressão que deixaram no imaginário político e social. Apesar das críticas contemporâneas em 1789, pouco tempo depois a imagem daquelas mulheres despertava empatia e até admiração. Finalmente, as parisienses da Marcha a Versalhes entraram para o repertório de símbolos republicanos. No festival de 10 de agosto de 1793 para comemorar o primeiro aniversário da insurreição que derrubou a monarquia planejado por David , havia quatro "estações" celebrando os principais acontecimentos revolucionários. Em ordem cronológica, ali estavam a queda da Bastilha, um arco do triunfo homenageando as heroínas de outubro de 1789, uma deusa da Liberdade e o Colosso-Hércules. Nenhum outro grupo feminino da Revolução chegou perto dessa glória ${ }^{285}$.

No dia 20 de junho de 1792, massas populares dos faubourgs Saint-Antoine e Saint-Marcel , entre elas numerosas mulheres armadas acompanhadas de seus filhos, invadiram o palácio das Tulherias, com o objetivo político de protestar contra a demissão dos ministros Girondinos, e plantar uma árvore da liberdade no jardim do palácio para comemorar o terceiro aniversário do juramento do Jeu de Paume. A multidão desfilou perante os deputados e o Rei, obrigado a colocar na cabeça o barrete frígio ${ }^{286}$. A iconografia aponta a visibilidade das mulheres na insurreição - elas fazem parte da família nacional em armas. As autoridades não intervieram, ou não puderam intervir contra o povo mobilizado e transformado numa verdadeira força armada. Depois do massacre de julho de 1791 no Campo de Marte, os responsáveis pelo

\footnotetext{
${ }^{284}$ Extrait du registre des délibérations du Conseil général de la Commune de Paris, du vendredi 5 avril 1792, l'an 4 de la liberté (Paris, 1792) IN LEVY, Darline Gay e APPLEWHITE, Harriet B., "Women, Radicalization, and the Fall of the French Monarchy" IN APPLEWHITE, Harriet B. \& LEVY Darline G. (edited by) Women \& Politics in the Age of the Democratic Revolution, Ann Arbor, The University of Michigan Press, 1993, pp. 90-91.

${ }^{285}$ HUNT, Lynn, Política, Cultura e Classe na Revolução Francesa, (trad.) São Paulo, Cia. Das Letras, 2007, p. 123.

${ }^{286}$ LEVY, Darline Gay e APPLEWHITE, Harriet B., "Women, Radicalization, and the Fall of the French Monarchy" IN APPLEWHITE, Harriet B. \& LEVY Darline G. (edited by) Women \& Politics in the Age of the Democratic Revolution, Ann Arbor, The University of Michigan Press, 1993, p. 91.
} 
controle de insurreições hesitaram em atirar na multidão, composta, em parte, de tantas famílias. O acontecimento deu ímpeto ao mito do povo soberano irreprimível, e fortaleceu as correntes radicais ${ }^{287}$.

Em agosto daquele ano, algumas mulheres participaram do combate violento da tomada do Palácio das Tulherias, onde residia a família real. Uma testemunha relata, com boa dose de exagero, que instantes antes da batalha, viu uma jovem discursando sobre uma pedra e em seguida milhares de mulheres se precipitaram na batalha, com sabres e piques, e outras encorajavam seus maridos, filhos e pais. Godineau diz que houve "algumas mulheres aqui e ali" que salvaram a vida dos companheiros tirando os fuzis dos guardas suíços do $\mathrm{Rei}^{288}$. Houve feridas. Dentre elas, três fizeram jus à coroa cívica: Théroigne de Méricourt, Louise Reine Audu e a jovem atriz Claire Lacombe. Pauline Léon ficou desapontada pois teve que ceder sua pique a um sans-culotte desarmado, atendendo as súplicas de outros patriotas. Mas só concordou depois de recomendar-lhe que fizesse bom uso de sua pique ${ }^{289}$. A vitória dos revolucionários em 10 de agosto de 1792 marcou o fim da monarquia, e o fim oficial da distinção entre cidadãos ativos e passivos. De 1793 a 1795 os homens de todas as classes sociais e níveis de renda tiveram plenos direitos políticos. As mulheres que contribuíram para este avanço democrático não foram incluídas ${ }^{290}$.

\section{$\underline{1.13 \text { - As mulheres soldados }}$}

Algumas mulheres não se contentaram em freqüentar as tribunas das assembléias e participar das lutas revolucionárias urbanas. Queriam mais. Quando a França declarou guerra à Áustria em 20 de abril de 1792 , elas se alistaram individualmente no exército para defender a pátria em perigo, e partiram para as

\footnotetext{
287 "Women and Militant Citizenship in Revolutionary Paris” I N MELZER, Sara e RABINE, Leslie W. (editoras), Rebel Daughters -Women and the French Revolution, New York - Oxford, Oxford University Press, 1992, p. 91.

${ }^{288}$ GODINEAU, Dominique, Citoyennes Tricoteuses - Les femmes du peuple à Paris pendant la Révolution Française, Paris, Editions Alinea, Perrin, 2004 , p. 121.

${ }^{289}$ LÉON, Anne Pauline, esposa de Leclerc, reconcilia seu comportamento político com os princípios e políticas radicais revolucionários - Archives Nationales, F7 4774 9, dossier Leclerc IN LEVY, Darline G., APPLEWHITE, Harriet B., JOHNSON, Mary D. - Women in Revolutionary Paris - 1789-1795 - . Selected documents translated with notes and commentary by the authors Urbana e Chicago, University of Illinois Press, 1980, p. 159.

${ }^{290}$ GODINEAU, Dominique, Citoyennes Tricoteuses - Les femmes du peuple à Paris pendant la
} Révolution Française, Paris, Editions Alinea, Perrin, 2004 , p. 122. 
fronteiras. Aderiram ao fervor patriótico dos soldados do Ano II, dispostas a viver o lema "Viver livre ou Morrer!".

Ao contrário dos antigos militares do Rei, que partiam obrigados e infelizes, na primeira fase da guerra boa parte dos soldados-cidadãos eram voluntários orgulhosos de sua missão. No Capítulo 2 há exemplos iconográficos das despedidas desses voluntários. Em dezembro de 1789, Edmond Dubois-Crancé já lembrava à Assembléia Nacional que "cada cidadão tem que ser soldado e cada soldado um cidadão". No antigo Regime, a soldadesca era desprezada pelos oficiais da nobreza e súditos civis do Rei ciosos de sua importância. Os jacobinos quiseram mudar essa atitude, valorizando os soldados, e proclamando que o serviço militar era a forma mais elevada de compromisso do cidadão com o Estado ${ }^{291}$. Afinal, era uma circunstância em que a Revolução e a pátria tinham que ser defendidas com a vida. Os líderes jacobinos queriam transformar os soldados em cidadãos-modelo: exaltaram seu espírito de sacrifício pela causa nacional, procuraram inspirar-lhes nobres sentimentos de solidariedade entre militares e civis, respeito pelos prisioneiros de guerra, defesa da comunidade, obediência às leis e aos representantes da nação, respeito pela propriedade particularmente em território estrangeiro, seguindo o lema "guerra aos castelos, paz às cabanas". Em outras palavras, este novo soldado substituiu a antiga honra pela virtude cívica ${ }^{292}$.

O clima de entusiasmo e o prestígio do engajamento militar inflamou as patriotas que se apresentaram ao exército como mulheres, ou disfarçadas de homens. Higonnet fala em "dúzias"293 delas, outros historiadores encontraram oitenta casos nos arquivos parlamentares, militares e policiais. Mas, segundo Godineau, só existem informações biográficas - esparsas e lacunares - acerca de quarenta e quatro soldadas. Em termos quantitativos elas são uma percentagem ínfima, quase anedótica, dos exércitos. Embora não se conheça o número correto, pois na época não se fez nenhum recenseamento, a historiadora francesa pensa que as mulheres-soldados não

\footnotetext{
${ }^{291}$ HIGONNET, Patrice, Goodness beyond Virtue, Cambridge, Massachusetts e London, England, Harvard University Press, 1998, p. 133.

${ }^{292}$ BERTAUD, Jean-Paul, "O Soldado", capítulo II IN VOVELLE, Michel, (direção) O Homem do Iluminismo, Lisboa, Editorial Presença p. 87.

${ }^{293}$ HIGONNET, Patrice, Goodness beyond Virtue, Cambridge, Massachusetts e London, England, Harvard University Press, 1998, p. 133.
} 
foram nem um mito, nem personagens de exceção ${ }^{294}$. De fato, a própria lei de 30 de abril de 1793 que excluiu as "mulheres inúteis"295 do exército demonstra tal fato. $\underline{\mathrm{O}}$ que me chamou a atenção para esse grupo de mulheres foi a sua representação na iconografia revolucionária. Há uma variedade de imagens, de artistas e gêneros diferentes, um tanto desproporcional ao número reduzido de soldadas encontradas nos arquivos. Baseada nessa constatação, fiquei com a impressão de que possivelmente eram mais numerosas e mais integradas ao cotidiano local do que seria o caso se fossem só personagens de exceção. É pertinente discutir a motivação das mulheres- soldados e as relações entre o feminino, o ofício das armas e a percepção masculina. Havia mulheres-soldados antes de 1789, ou essas personagens surgiram no calor das paixões da França revolucionária?

No Antigo Regime, algumas mulheres participaram de guerras, principalmente as pertencentes à nobreza "de espada"296. O porte de armas estava ligado à condição masculina e aristocrática, mas em situações especiais, as esposas dos nobres se envolveram em conflitos armados, não raro substituindo os homens da família. Houve o caso de Madame de la Guette, do tempo da Fronda e da Guerra dos Trinta Anos. Ela não chegou a combater diretamente, mas era exímia amazona e hábil no manejo de armas. Nas suas Memórias, afirmou que preferia os exercícios da guerra ao fuso de fiar, e achava o som dos canhões e das trombetas "mais agradáveis que as melhores sinfonias". Esposa e mãe, portanto preservando sua feminilidade, não transgrediu as normas de comportamento, pois esperava-se que membros da nobreza tivessem qualidades guerreiras. Catarina de Médicis conduziu o exército francês no cerco de Havre "expondo-se aos arquebuses e tiros de canhão como um de seus capitães"(Brantôme) ${ }^{297}$. Ainda outras participaram de batalhas : Mlle. de Montpensier

\footnotetext{
${ }^{294}$ GODINEAU, Dominique De la guerrière à la citoyenne. Porter les armes pendant l'ancien Régime et la Révolution française, CLIO - Histoire, femmes et sociétés, 20-2004 , pp. 43-69

295 [Convention Nationale] Archives Parlementaires 30 avril 1793; Archives nationales: Carton CII 251, chemise 427, pièce no. 11.

${ }^{296}$ Informações do parágrafo IN GODINEAU, Dominique De la guerrière à la citoyenne. Porter les armes pendant l'ancien Régime et la Révolution française, CLIO - Histoire, femmes et sociétés, 202004 , pp. 43-69

${ }^{297}$ Informações deste parágrafo IN GODINEAU, Dominique De la guerrière à la citoyenne. Porter les armes pendant l'ancien Régime et la Révolution française, CLIO - Histoire, femmes et sociétés, 20-2004, pp. 43-69.
} 
no cerco de Orléans em 1652, e Madame Saint-Balmont, a qual, vestida de homem, defendeu suas terras durante a Fronda, enquanto o marido estava em combate. Durante as guerras de religião, a esposa de Coligny e a viúva Madeleine de Miraumont lideraram batalhões contra inimigos católicos. Entretanto, essas mulheres eram exceção, e o que seria condenável em outras, nelas era distinção e qualidade ligada ao sangue nobre e posição social. Assim mesmo, havia limites para esse envolvimento: a repulsa à mulher que deixa de ser feminina para "invadir a seara masculina", como deixa claro um depoimento masculino da época:

"Que as mulheres sejam mulheres, não capitãs: se a doença dos maridos, a menoridade dos filhos as obrigam a se apresentar no combate, tal coisa é tolerável uma ou duas vezes em caso de necessidade" - melhor seria que "ficassem longe dos acampamentos onde eram alvo de insultos dos inimigos e zombaria dos amigos" ${ }^{298}$.

O que mudou na percepção do serviço militar com a Revolução? Na visão revolucionária, as guerras eram travadas entre "homens livres" e "escravos de tiranos". Os soldados agora eram cidadãos defendendo a pátria, e não mais súditos a serviço do Rei. Quase sempre, as aristocratas guerreiras lutavam por causas de natureza particularista : suas terras, seus privilégios, religião e classe social, muitas vezes na falta do marido. As soldadas de 1792 lutavam pelos ideais da Revolução, que eram universalistas na visão dos revolucionários. E não se engajavam no lugar do marido ou dos parentes, lutavam junto com eles. Quase todas as mulheres-soldados vinham de meios sociais modestos, eram filhas de pequenos camponeses, artesãos ou operários: chamavam-se Rose, Marianne, Reine ou Liberté, e tinham apelidos como Va-de-boncoeur (vai-de-bom-coração) Marie-tête-de-bois (Maria cabeça-de-pau), Sans-souci (sem preocupação). Tinham menos de trinta e cinco anos, e a maioria era muito jovem, como a cidadã Quatresols, que com dezesseis anos, durante uma batalha, teve dois cavalos que montava alvejados e mortos debaixo de seu corpo. Guerrearam ombro a ombro com seus companheiros de armas, compartilhando com eles as agruras da vida

\footnotetext{
298 TAVANNES, Mémoires du capitaire Gaspard de Saulx-Tavannes, citado por Steinberg 2001:219, IN GODINEAU, Dominique De la guerrière à la citoyenne. Porter les armes pendant l'ancien Régime et la Révolution française, CLIO - Histoire, femmes et sociétés, 20-2004 , pp. 43-69 .
} 
militar. Demonstraram coragem em todos os cercos e batalhas; muitas foram homenageadas, receberam gratificações e parte delas, pensões do governo ${ }^{299}$.

Em 1792 o sufrágio censitário foi abolido, assim como as categorias de cidadãos passivos e ativos, sendo que os passivos já tinham entrado para a Guarda Nacional antes do fato. Como as mulheres não podiam entrar para Guarda Nacional, portar armas, nem votar, alistar-se no exército tinha a dimensão política da integração oficiosa à cidadania. Não me parece, entretanto, que esta tenha sido a razão principal de seu engajamento militar. Nos Anos I e II, não podemos menosprezar o que os franceses chamam de "a força ativa dos princípios" (la force agissante des principes). A pregação revolucionária e republicana do espírito público, do dever e da glória de defender "um povo livre" contra os tiranos da Europa encontrou adeptas entre as cidadãs mais intrépidas. Arriscar a vida na guerra não deixava de ser a mais extrema demonstração de compromisso com a cidadania e de amor à pátria. De certa forma, é a militância no seu mais alto nível. Houve ainda razões pessoais importantes para o alistamento feminino: muitas vieram para acompanhar maridos, amantes ou irmãos, outras tinham "nascido na caserna", vinham de famílias de militares.

$\underline{\text { Penso que a originalidade dessas voluntárias está no fato de haverem criado }}$ um espaço próprio, que unia o sacrifício pela nação e pela Revolução ao devotamento conjugal ou familiar. As mulheres-soldados uniram um terreno essencialmente masculino à sensibilidade feminina de uma forma que despertou reconhecimento e admiração até entre os jacobinos da Convenção, em geral arredios à situações de "confusão" ou "troca" de papéis sexuais. A meio caminho entre as mães que se limitavam à esfera doméstica e as militantes que participavam assiduamente da vida política está a mulher-soldado que cuidava do marido e lutava pela pátria ao mesmo

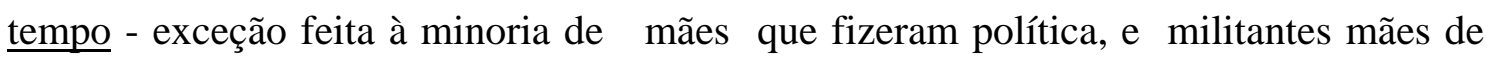
filhos pequenos.

Há algumas histórias de amor comoventes entre maridos e mulheres- soldados. O Capitão Dubois guerreou ao lado da mulher, ela também combatente, no $7^{\circ}$ Batalhão de Paris. Quando ele foi ferido, os soldados a escolheram para ser vice-capitã. A

\footnotetext{
${ }^{299}$ GODINEAU, Dominique, Citoyennes Tricoteuses - Les femmes du peuple à Paris pendant la Révolution Française, Paris, Editions Alinea, Perrin, 2004 , p. 241.
} 
viúva do soldado Soutemane, "animada de um ardor marcial", combateu junto com o marido no $21^{\circ}$ regimento de cavalaria ligeira. Ele foi morto em Marengo, e ela, ferida na coxa , teve que deixar o regimento, onde até então havia dissimulado seu sexo. Há o testemunho de Philippe-René Girault, do $6^{\circ}$ Batalhão da Haute-Saône: viu um "soldado" abraçando o cadáver de outro, gritando e chorando de desespero. Desconfiou de seu sexo. Confrontada, a mulher-soldado confessou que há três anos servia junto com o marido e que os dois sustentavam um filho nas redondezas com suas economias. Os companheiros de armas fizeram uma coleta para ajudá-la e foi-lhe concedida uma pensão. O que alertou os soldados foi " a sensibilidade tão grande em um soldado que assistia todos os dias a cenas de carnificina" ${ }^{300}$. Os homens respeitavam a coragem e a sensibilidade femininas, cada qualidade no momento certo.

Em $1^{\circ}$ de agosto de 1793 a Convenção concedeu uma gratificação de 300 libras a Liberté Barreau para recompensá-la pela sua bravura sob as bandeiras [francesas] ("sous les drapeaux") . Aos dezenove anos, ela servia no $2^{\circ}$ Batalhão de Tarn, Regimento dos Pirineus Ocidentais, na mesma companhia de seu marido, François Leyrac. Ela "se mostrou mais que um homem" na batalha. Seu irmão e seu marido feridos aos seus pés, ela perseguiu os inimigos até a sua debandada, e então Liberté Barreau voltou para cuidar do marido, e transportá-lo ao hospital militar, com a ajuda dos companheiros de armas. Ali cuidou dele com toda a ternura conjugal, provando que "não havia renunciado às virtudes de seu sexo", apesar de ter demonstrado todas aquelas que deveriam ser o apanágio do outro ${ }^{301}$. Barreau impressionou seus companheiros de armas pela intrepidez na luta, mas também pelas qualidades femininas, como a devoção e o carinho com o marido.

Algumas misturavam ao sentimento patriótico, o gosto da aventura e o desejo de dividir com os homens a glória de combater pela Revolução. Reine Chapuy, de dezessete anos, disse que se alistara : "(...) pelo desejo ardente de combater os tiranos e compartilhar da glória de fulminá-los". Rose Bouillon não foi menos heróica que Liberté Barreau. Suas razões: " aplaudindo o patriotismo do marido, e querendo também contribuir para o fortalecimento da República, (...) veio se encontrar com o

\footnotetext{
${ }^{300}$ MARAND-FOUQUET, Catherine, La femme au temps de La Révolution - Paris, Éditions Stock/Laurence Pernoud, 1989, pp. 164-166.

${ }^{301}$ GERBAUX, F., La Révolution Française - Revue Historique, tome 47, 1904 /07, pp. 53-54, microfilm LC18-333, Bibliothèque Nationale François Mitterrand.
} 
marido" ${ }^{302}$. Casada com Julien Henry, deixou dois filhos (um com apenas sete meses de idade) com sua mãe para se unir ao marido no $6^{\circ}$ batalhão da Haute-Saône, no exército da Mosela. Escondendo seu sexo, admitida como voluntária, ela serviu com distinção de março a agosto de 1793. Seu marido foi morto ao seu lado, mas ela não parou de lutar até o batalhão se retirar. Então pediu dispensa do exército para cuidar dos filhos do mesmo modo que havia se dedicado ao marido e à pátria. A Convenção concedeu a Rose Bouillon uma pensão de 300 libras e mais 150 para cada um de seus filhos em agosto de $1793^{303}$.

Há muitos exemplos de fervor patriótico: Marie Charpentier, única mulher na lista dos vencedores da Bastilha, viúva de um sargento, alistou -se como soldadopolicial e serviu até 1796. A jovem revolucionária parisiense Catherine Pochelat, que em 10 de agosto de 1792 operou um canhão na tomada das Tulherias, entrou para o $71^{\circ}$ regimento de infantaria, vencedor da batalha de Jemmapes. Em seguida, na legião das Ardenas, demonstrou tamanho destemor que seus companheiros de armas a elegeram sub-lugar-tenente. Em Jemappes, a jovem belga Marie Schellinck foi ferida e promovida a sub-lugar-tenente pelo General Rosières. Marie serviu no exército de 1792 até sua morte em $1802^{304}$. A jovem patriota Félicité Duguet, de Versalhes, lutou sob identidade falsa com o apelido Va-de-bon-Coeur, se inscreveu no $1^{\mathrm{o}}$ Batalhão da Nièvre porque "o amor sagrado da pátria que a inspira não lhe permite olhar com sangue frio os perigos que a ameaçam" ${ }^{305}$. Algumas tinham vocação militar: Angélique Duchemin, viúva Brulon, era filha, irmã e esposa de soldados, e desde cedo mostrou inclinação pela carreira militar. Em 1792 foi autorizada pelo General Casabianca a servir como soldada no $42^{\circ}$ Regimento de Infantaria de linha, apesar do sexo. Na batalha pelo forte de Gesco (24 de maio de 1794) , partiu à meianoite para buscar sessenta sacos de munição em Calvi, possibilitando a defesa e conservação do forte. Ferida , teve que se retirar para o Hôtel des Invalides onde foi promovida a sub-lugar-tenente. Mais tarde, Napoleão III condecorou-a com a cruz da

\footnotetext{
302 GODINEAU, Dominique De la guerrière à la citoyenne. Porter les armes pendant l'ancien Régime et la Révolution française, CLIO - Histoire, femmes et sociétés, 20-2004 , pp. 43-69

${ }^{303}$ GERBAUX, F., La Révolution Française - Revue Historique, tome 47, 1904 /07, pp. 33-34, microfilm LC18-333, Bibliothèque Nationale François Mitterrand., p. 54.

${ }^{304}$ BERTAUD, Jean-Paul, capítulo V, " Les femmes et les armées de la République' IN La vie quotidienne des soldats de la Révolution 1789-1799, pp. 153 -156.

${ }^{305}$ ROSA, Annette, Citoyennes, Paris, Messidor, 1988 , p. 191.
} 
Legião de Honra e a medalha de Santa Helena, "dupla consagração de seus serviços de guerra, cuja gloriosa memória ainda iluminam o declínio de seus dias"306.

As cantineiras ajudavam em tudo: cuidavam dos feridos, e abriam fogo se fosse preciso atirar. Houve uma, chamada Marie-tête-de-bois (Maria-cabeça-de-pau) " feia de dar medo", que apesar disso achou um soldado para casar-se com ela, deu à luz em plena batalha de Marengo e a lenda diz que estava na última formação do quadrado (le dernier carré) dos bravos em Waterloo ${ }^{307}$. O exército realista e católico da Vendéia também era acompanhado por uma multidão de mulheres, crianças e velhos que fugiam das devastações dos revolucionários Bleus. De acordo com a Marquesa de la Rochejaquelein, havia dez mulheres-soldados nas tropas, sendo que a mais famosa foi Renée Borderau, a "brava de Angevin", sem contar algumas nobres que acompanharam os maridos.

As irmãs Fernig são uma exceção: nobres, com idades de dezessete e vinte e dois anos , elas se armaram junto com os habitantes de sua pequena cidade para defender sua terra de Mortagne, perto da fronteira belga, contra os "Imperiais". Combateram no exército do General Dumoriez vestidas de homem, atacando arrojadamente. Mas fora da batalha se vestiam de mulher, sempre levando uma carabina a tiracolo. Segundo Marand-Fouquet, praticavam a guerra "por amor à arte" (elles pratiquaient le guerre comme un art d"agrément) ${ }^{308}$. Seja como for, as duas viraram heroínas da liberdade na França e foram reconhecidas pelo governo convencional. Na sessão da Convenção em 15 de novembro de 1792, sob a presidência de Hérault de Sechelles, há várias menções elogiosas às irmãs ${ }^{309}$ : " A Convenção Nacional aprovará o que todo o exército lhe recomenda - as cidadãs Fernig - que se distinguem em todos os destacamentos avançados, e cuja casa em Mortagne foi pilhada e arrasada pelos ferozes austríacos" (aplausos) O General Dumoriez as recomendou

\footnotetext{
${ }^{306}$ BERTAUD, Jean-Paul, capítulo V, " Les femmes et les armées de la République' IN La vie quotidienne des soldats de la Révolution 1789-1799, pp. 153 -156.

${ }^{307}$ GODINEAU, Dominique De la guerrière à la citoyenne. Porter les armes pendant l'ancien Régime et la Révolution française, CLIO - Histoire, femmes et sociétés, 20-2004 , pp. 43-69

${ }^{308}$ MARAND-FOUQUET, Catherine, La femme au temps de La Révolution - Paris, Éditions Stock/Laurence Pernoud, 1989, p. 166.

${ }^{309}$ [Convention Nationale] Archives Parlementaires 16 novembre 1792 ; Bibliothèque Nationale François Mitterrand.
} 
numa carta: "eu recomendo à Convenção Nacional as duas irmãs Fernig: são guerreiras intrépidas" O deputado Prieur declarou: "É a segunda vez que o General Dumoriez nos fala das duas jovens heroínas que combatem pela liberdade (...) É preciso decretar, a partir de hoje, que sua casa será reconstruída por conta da República. (...) peço que no fim da campanha as duas heroínas sejam dotadas pela República". F. Gerbaux , em seu estudo Les femmes soldats pendant la Révolution, de $1904^{310}$ fez uma lista de vinte e quatro nomes, ações e gratificações pagas a essas mulheres, e aqui estão alguns exemplos: Catherine Pochelat, 300 libras; Antoinette Vitteau, 200 libras; Marie Savonneau, 500 libras; Claude Rouget, 500 libras, Anne-Françoise-Pélagie Dulière, 1.200 libras; Marie Louise Thérèse Bouquet, 150 libras; Reine Chapuy, 300 libras; Anne Quatresols, 500 libras; Françoise Rouelle, 600 libras.

Apesar dos serviços prestados pelas muheres-soldados, a Convenção decidiu promulgar um decreto em 30 de abril de 1793 dispensando e excluindo do exército todas as "mulheres inúteis", entre elas as soldadas. Vejamos as razões: " Cidadãos: os generais já vos dirigiram queixas várias vezes sobre o grande número de mulheres que seguem os batalhões. Na retirada da Bélgica, elas formavam um segundo exército. Além de absorverem uma parte necessária das subsistências, elas atrapalham a marcha das tropas, atrasam o transporte das bagagens acomodando-se nas carroças, e tornam as retiradas difíceis e perigosas; são fonte de desentendimentos, desencorajam os soldados; são objeto de distração e dissolução para todos os militares, dos quais elas amolecem a coragem". O General Dumouriez foi duramente criticado por ter dado mau exemplo aos soldados: cercou-se de tantas amantes, cantoras e atrizes que seu alojamento parecia um "harém de vizir". Para resolver todos esses problemas, foi decretado que: "Artigo I: Oito dias depois da promulgação do presente decreto, os generais, chefes de brigada, chefes de batalhões e todos os outros comandantes, mandarão embora dos alojamentos e acampamentos todas as mulheres inúteis ao serviço dos exércitos". "Artigo 2: serão consideradas inúteis todas aquelas que não se ocupam com a lavanderia e a venda de víveres e bebidas". O decreto também se aplicava às esposas de todos os oficiais. "Artigo 11: as mulheres que servem atualmente nos exércitos serão excluídas do serviço militar. Elas receberão um passaporte e cinco sous por légua para voltarem aos seus domicílios" .

${ }^{310}$ GERBAUX, F., op. cit. 
O decreto estava de acordo com a definição revolucionária dos papéis sexuais, inspirada em Rousseau. Os homens eram responsáveis pelos negócios "externos" ao lar: a cidade, a pátria, o governo e a guerra eram seu apanágio. Já a mulher estava destinada pela sua natureza às responsabilidades "internas" do lar: os filhos, a alimentação da família, administração da casa, o devotamento ao marido. As quitandeiras e as lavadeiras podiam ficar no exército porque tinham o papel feminino de nutrizes, cuidavam da alimentação e da higiene dos soldados. As quitandeiras compravam gêneros alimentícios nas redondezas dos acampamentos e revendiam aos soldados, que, de outra forma, teriam uma dieta muito pobre. As lavadeiras, ao cuidar da higiene, também ajudavam a mantê-los saudáveis. Todas as outras eram consideradas pelos legisladores estorvos à disciplina e ao bom andamento das campanhas. Além das esposas e amantes dos oficiais, havia numerosas prostitutas que transmitiam doenças como a sífilis, deixando os homens apáticos e sem vigor. As mulheres-soldados eram poucas, e não eram "inúteis" - segundo essa definição, o decreto não se referia a elas, exceto que havia um artigo específico ordenando sua dispensa. Portanto , a sua exclusão era uma advertência e servia para dissuadir aquelas que tinham a intenção de entrar para as forças armadas. O objetivo era deixar bem claro que os homens não precisavam de ajuda no combate nem exemplos de coragem das mulheres. Para a força, a destreza e a ação violenta havia o sexo masculino.

Mas o comportamento das mulheres-soldado desmentia a fraqueza do sexo , por isso sua coragem era explicada como "uma exceção" e um "milagre da Liberdade" e do ódio aos tiranos. Em outras palavras, os princípios revolucionários davam às mulheres qualidades masculinas se fosse preciso. Collot d"Herbois declarou que considerava a exímia guerreira Anne Quatresous um homem, pois o heroísmo bélico era um atributo só masculino: eis aí um caso explícito de negação da realidade em favor do preconceito. Alguns homens se queixavam abertamente das mulheres promovidas a oficiais, e um cidadão protestou contra uma delas no Exército do Norte: "os soldados têm vergonha todos os dias de receber suas ordens, o que os desagrada 
infinitamente" - e denunciou a situação como ilegal ${ }^{311}$. O jornalista Prudhomme se manifestou em Révolutions de Paris contra a presença feminina nas tropas: "Deixemnos o ferro e os combates; seus dedos delicados foram feitos para segurar a agulha e semear de flores o caminho espinhoso da vida. Para vocês, o heroísmo consiste em carregar o peso da administração caseira e das penas domésticas".

Mas uma coisa era a lei, e outra a realidade das frentes de batalha. O decreto de abril de 1793 nunca foi cumprido. As esposas e companheiras dos soldados continuaram seguindo as tropas e a maioria das combatentes permaneceu no exército como se nada tivesse acontecido. Muito poucas foram dispensadas em função da lei de abril. Os chefes militares apreciavam sua cooperação e simplesmente ignoraram a lei. Em janeiro de 1794 um adjunto do ministro da Guerra escreveu ao General Charbonnié: "o decreto expulsando as mulheres inúteis do exército não é cumprido devido a interpretações abusivas; (...) esses abusos convinham aos satélites do Rei, mas são indignos dos soldados republicanos". As mulheres a que se referia o funcionário eram as companheiras dos soldados, não as militares. Na prática, estas não eram vistas como "mulheres inúteis". Algumas pediram aos deputados da Convenção permissão para continuar no serviço: eles elogiaram sua coragem, concederam pensões mas negaram a permanência no exército. O capitão da Sra. Fartier , canhoneira no $10^{\circ}$ batalhão dos Federados Nacionais de Paris, autorizou-a por escrito a continuar servindo na companhia. A cidadã Ledague, vinte anos de idade, tinha se destacado no cerco de Lille, e queria a "glória" de participar da próxima campanha, mas só partiria com o assentimento dos "verdadeiros republicanos" da assembléia geral da Seção dos Amigos da Pátria. Seu discurso foi aplaudido entusiasticamente, e a assembléia inscreveu-a como voluntária no batalhão da Seção. Anne Quatresols se alistou aos treze anos, serviu três anos na cavalaria (artilharia montada) e brilhou em várias batalhas na Bélgica. Foi recebida com grandes aplausos no clube dos Jacobinos, os quais fizeram uma coleta em seu favor. O representante em missão no Exército do Norte, Goussin, exaltou Anne Quatresols "por sua dedicação aos deveres, a decência de sua postura e

\footnotetext{
${ }^{311}$ Informações do parágrafo IN GODINEAU, Dominique De la guerrière à la citoyenne. Porter les armes pendant l'ancien Régime et la Révolution française, CLIO - Histoire, femmes et sociétés, 20-2004, pp. 43-69
} 
sua perseverança em calar seu segredo"312 - decerto se vestia como homem. A cidadã Vadeboncoeur quase conseguiu ficar no seu regimento quando o conselho militar votou a seu favor, pois : " a cidadã Vadeboncoeur sempre se comportou de maneira irrepreensível e que ele [o conselho] não tem conhecimento de lei que a torne passível de exclusão do batalhão". Mas um General superior fez cumprir a lei.

Apesar da lei, houve mulheres-soldados até nas guerras napoleônicas. Há uma carta de 1805 (incluída na seção dos anexos) ao Imperador, escrita por Madame de Xaintrailles $^{313}$, ex-combatente, reclamando direitos iguais para mulheres e homens à pensão do exército: "Fiz sete campanhas do Reno como ajudante-decampo; fiz parte da última expedição ao Egito (...)" Ela pede justiça do Imperador, pois sua demanda de pensão ou emprego era recusada porque era mulher. Assinala a Napoleão que ela era mulher quando tomou a artilharia de canhões do Príncipe Ombourg, quando impediu uma revolta da $44^{\text {a }}$ semi- Brigada de Infantaria, quando atravessou um rio a nado para entregar uma mensagem ao General Comandante entre Kayerslautern e Neustadt (...)" E termina sua missiva com um argumento irretorquível: "Não fiz a guerra como mulher, fiz a guerra como um bravo " (Sire, ce n"est point en femme que j"ai fait la guerre, je l'ai faite en brave...") (grifo da autora ). Neste caso, não se trata de uma adolescente patriota que se satisfaz com um elogio e uma gratificação. Trata-se de uma mulher madura e consciente que enxerga a injustiça de sua situação, e faz questão de colocar o dedo na ferida: o que importava era o cumprimento do dever, da função militar, e não o sexo de quem o desempenhava. Nesse sentido, homens e mulheres deveriam ser iguais aos olhos da pátria - $\underline{\text { o sexo }}$ desaparecia para dar lugar ao bravo. Madame de Xaintrailles era prussiana, mas como outras estrangeiras nas fileiras do exército, combateu pela França contra seus antigos compatriotas. $\quad \mathrm{O}$ tom e a indignação da autora da carta remetem às revolucionárias feministas do início da Revolução. Mas os tempos eram outros. Com a promulgação do Código Civil em 1804, a igualdade de direitos entre os sexos virou um sonho impossível para a maioria das mulheres. A ex-combatente tinha poucas chances de ser ouvida no ambiente patriarcal da época. Napoleão pediu ao Ministro

\footnotetext{
${ }^{312}$ GERBAUX, F., La Révolution Française - Revue Historique, tome 47, 1904 /07, pp. 33-34, microfilm LC18-333, Bibliothèque Nationale François Mitterrand, p. 57.

${ }^{313}$ MADAME XAINTRAILLES, Carta ao Imperador, IN BERTAUD, Jean-Paul, capítulo V, " Les femmes et les armées de la République" IN La vie quotidienne des soldats de la Révolution 17891799, pp. 150-151.
} 
da Guerra que fizesse um relatório particular. Não se sabe o que aconteceu depois, porém, mas a falta de uma resposta afirmativa permite supor o pouco interesse pelo caso.

Apesar de algumas vozes discordantes, impressiona a boa vontade e a acolhida calorosa às mulheres-soldados por parte dos chefes militares e até dos líderes revolucionários em Paris. Quantos casos de condecorações, gratificações e pensões, para não falar nos aplausos e elogios! Isso levando-se em conta que elas transgrediam as normas de comportamento feminino, apropriando-se de atributos inerentemente masculinos como as armas e o serviço militar. Foram até certo ponto aceitas porque tinham moeurs, (moral e bons costumes) comportavam-se com profissionalismo e dignidade, ou seja, eram soldadas e não prostitutas. Essas qualidades eram essenciais numa mulher, principalmente numa época em que Amar e Chaumette repreendiam as mulheres "imorais" que "se queriam homens" ou "saíam de seu sexo" por participarem da vida pública. Ao ordenar o fechamento das associações políticas femininas em nome do Comitê de Segurança Pública, Amar declarou que o papel da mulher era uma questão moral, e "sem moral não há República". Muitas mulheressoldados serviram ao exército disfarçadas de homem e com identidades falsas para conseguirem alistar-se, e, não menos importante, para se protegerem do perigo da violência sexual. Assim, tinham um comportamento reservado a ponto de seu sexo só ser descoberto quando eram feridas em combate. $\mathrm{O}$ argumento utilizado contra as mulheres armadas era o fato de "não terem sido feitas para dar a morte, mas sim a vida", dando à luz e aleitando os filhos. Mas na guerra, elas matavam os "escravos dos tiranos": prestavam um serviço à nação, protegendo os cidadãos da sanha inimiga. Em compensação, ao cuidar dos feridos e doentes estavam proporcionando uma esperança de vida a esses patriotas em perigo. Nesse função, demonstravam sensibilidade, doçura e altruísmo associados ao sexo feminino. Além de ressaltar o denodo na batalha, o ambiente da guerra se prestava à prática da devoção ao próximo, o que estava de acordo com o espírito republicano professado e apreciado pelos líderes revolucionários.

A importância da propagação das virtudes republicanas era crucial, e no dia 28 de setembro de 1793, a Convenção decidiu formar um comitê de instrução pública para "recolher os traços exaltados das virtudes que marcaram a Revolução; é uma tarefa 
honrada, porque ocupar-se de recolher as ações dos homens ilustres é respirar a virtude, é associar-se à sua glória. (...) em geral, poucos homens agem por princípio, quase todos imitam (..) o caráter da maioria é o produto dos exemplos que passaram por seus olhos (...) " Dessa forma, a Convenção Nacional autoriza o comitê de instrução a se corresponder com os exércitos, autoridades constituídas e sociedades populares para descobrir e recolher exemplos de ações heróicas e virtuosas dos cidadãos para divulgá-las e estimular sua imitação" ${ }^{314}$. Havia então uma plano para encontrar os heróis e glorificá-los. Que tipo de qualidades ou situações seriam privilegiadas nas publicações? As virtudes, idades ou estados consagrados em lei: "A República francesa declara em sua Constituição que ela honra a lealdade, a coragem, a velhice, a piedade filial e a desgraça (le malheur)". $\quad$ Assim, em 10 nivoso do Ano 2 da República una e indivisível, foi publicado o Recueil des Actions Héroiques et civiques des Républicains française ${ }^{315}$, que continha, entre outros relatos de bravura, $\underline{\text { as }}$ histórias de duas mulheres-soldados, Liberté Barreau e Rose Bouillon. Era o panteão da glória, a distinção moral máxima fazer parte dos exemplos de virtude no Recueil... A pergunta que surge é: por que justamente duas soldadas, que pegaram em armas e "deram a morte"? Porque também deram a vida , cuidaram dos maridos e dos filhos e se sacrificaram pela pátria. E o fizeram sem " esquecer as virtudes de seu sexo" - eis aí o grande mérito. Mártires dão exemplo, mas são exceções. As mulheres-soldados podiam servir de exemplo porque eram exceções à regra, e portanto não representavam ameaça à hierarquia dos sexos. No vocabulário da época, conseguiram "elevar-se acima do sexo", ficando bem entendido que apenas algumas conseguiam superar o limite de suas forças físicas e morais para atingir qualidades superiores, eminentemente masculinas. Mesmo assim, as soldadas eram coadjuvantes, foram ajudar e não competir com os homens; mantiveram intacta a sua feminilidade e sua virtude e não ameaçaram a supremacia masculina. No ambiente da República da Virtude, em meio à ambição da regeneração moral da sociedade francesa, e a correspondente redefinição dos papéis dos gêneros, pode-se dizer que as mulheressoldados contribuíram com um modelo de comportamento feminino positivo.

\footnotetext{
314 Procès -verbaux de la Convention, 1.21, p. 298.[convention Nationale] Archives Parlementaires 28 septembre 1793, Bibliothèque Nationale, le, no. 473.

${ }^{315}$ Recueil... (Presenté à la Convention Nationale au nom de son Comité d'instruction publique, par Léonard Bourdon, an II, Paris, Imprimerie Nationale) microfilme da Bibliothèque Nationale François Mitterrand, Paris.
} 
Apesar do governo revolucionário repetir de 1792 até o Consulado que as mulheres serviriam melhor à pátria como mães no lar do que como militares na fronteira, penso que o caso sui generis das mulheres-soldados foi apropriado pelas autoridades para enriquecer a coleção dos exemplos insignes, das imagens que vão além da realidade, dos heroísmos mitificados. Todas elas protagonizaram episódios de coragem incomum, foram heroínas maiores que a vida. Até onde tais relatos são verdadeiros, ou em que medida foram "embelezados" ou "magnificados" com objetivo de propaganda do espírito republicano? Acho que as guerreiras foram festejadas porque, ao lado de outros "grandes homens" leais e abnegados , alguns até "mártires" republicanos , podiam instruir e inspirar uma nação às voltas com guerra externa, guerra civil, inflação, penúria e revoltas urbanas. Refletindo sobre as descrições sempre exaltadas dos feitos marciais das soldadas, aliados à condição sine qua non da moral ilibada, as gratificações pecuniárias e aplausos que mereceram do governo revolucionário, tenho a impressão de que elas foram de certa forma mitificadas para figurar no panteão dos exemplos patrióticos de que a Revolução tanto precisava no ano II. Fica aqui uma questão intrigante para estudos futuros.

\subsection{4 - Subsistência e taxação popular}

Uma das razões para o envolvimento das mulheres sans-culottes no movimento popular foi a crise econômica, e mais precisamente a falta e a carestia dos gêneros alimentícios. Vejamos que práticas as ativistas adotaram para tentar resolver tais problemas. Em janeiro e fevereiro de 1792, devido à guerra civil entre monarquistas e patriotas nas colônias francesas nas Índias Ocidentais, faltava açúcar em Paris. Os especuladores açambarcavam imensas quantidades de açúcar, café e chá apostando na alta dos preços, que, de fato , atingiram níveis acima do alcance da maioria da população. As lavadeiras e operárias dos bairros populares levaram petições à Comuna e à Assembléia Legislativa para protestar, porém as reclamações foram ignoradas ${ }^{316}$. Estourou a revolta: grupos de populares, muitas vezes reunidos pelas mulheres, percorriam as mercearias do centro e dos Faubourgs Saint-Marcel e

\footnotetext{
${ }^{316}$ LEVY, Darline G., APPLEWHITE, Harriet B., JOHNSON, Mary D. - Women in Revolutionary Paris - 1789-1795 - . Selected documents translated with notes and commentary by the authors Urbana e Chicago, University of Illinois Press, 1980, p. 105.
} 
Saint-Antoine, procedendo à chamada taxação forçada, isto é, forçando os comerciantes a venderem as mercadorias a "preços justos", estabelecidos ali na hora pelos "fregueses" 317.

A seguir alguns testemunhos: o primeiro é um comentário de um jornal liberal, o Patriote français de 22 de janeiro, 1792, que condenava a violência popular atribuída à contra-revolução. "Ontem, os residentes do Faubourg Saint-Marceau arrombaram um armazém (...) e o açúcar ali açambarcado foi vendido por vinte e um sous a libra. Todos os que o levaram pagaram fielmente!"318.

Gorsas relatou no Le Courier des 83 Départements em 23 de janeiro, 1792: "A expedição para o Faubourg Saint-Marceau espalhou o medo entre os açambarcadores e aqueles que alugam seus armazéns a eles. Anteontem à noite, patrulhas encontraram carroças vindo de todos os lados carregadas com açúcar e café. Em muitos armazéns só restou soda" ${ }^{319}$.

Memórias de um guarda do armazém Monnery que tentou impedir a invasão do lugar, "Fragment des Mémoires de Charles -A. Alexandre": "O povo tinha razão em reclamar, mas não em usar de ameaças e violência". Os especuladores diziam que o açúcar era um produto de luxo e por isso o preço não podia ser congelado, mas o guarda Alexandre pensava que fazia muito tempo que o açúcar tinha se transformado em gênero de primeira necessidade. "as mulheres eram as mais furiosas(grifo meu) com os açambarcadores e as mais ameaçadoras(...)" Alexandre notou as táticas de taxação popular invocadas pelas mulheres para obter "uma espécie de justiça distributiva, que é porém manchada em seus princípios pela violência". "As mulheres eram as mais exaltadas - eram verdadeiras fúrias" (grifo meu) Como o armazém estava bem defendido, elas foram para a Igreja Saint-Marcel, e tocaram os sinos em sinal de alarme - milhares de pessoas acudiram dos bairros vizinhos. Apenas alguns barris foram tirados do depósito e vendidos" ${ }^{320}$.

\footnotetext{
${ }^{317}$ GODINEAU, Dominique, Citoyennes Tricoteuses - Les femmes du peuple à Paris pendant la Révolution Française, Paris, Editions Alinea, Perrin, 2004 , p. 124.

${ }^{318}$ LEVY, Darline G., APPLEWHITE, Harriet B., JOHNSON, Mary D. - Women in Revolutionary

Paris - 1789-1795 - . Selected documents translated with notes and commentary by the authors Urbana e Chicago, University of Illinois Press, 1980 , p. 108

319 idem, p. 110.

320 idem, p. 115.
} 
Vários documentos mostram que as autoridades tanto locais como nacionais eram solidárias com os revoltosos porém não podiam permitir os ataques à propriedade privada. Em geral se expressaram no sentido de pedir clemência para os perpetrantes da taxação popular , culpando gente de fora pelos distúrbios: Pétion fala em "são pais e mães de famílias inocentes"; um membro da Assembléia Legislativa se refere às" lavadeiras e operárias do bairro que caíram numa armadilha preparada para elas" " muitos estão presos na Conciergerie: todos são pais e mães de famílias numerosas que sofrem porque seus pais estão detidos (...) agiram por impulso, sendo puros de coração (...)" ${ }^{321}$.

Na primavera de 1792, os deputados Girondinos decidiram pedir às mulheres que se sacrificassem e boicotassem o açúcar para forçar a baixa dos preços - elas concordaram em não utilizar o produto. Entretanto, seu apoio aos Girondinos declinou pois eles continuavam com seu programa econômico liberal, recusando-se a controlar os preços e a distribuição eqüitativa de alimentos. O radical Enragé Jacques Roux atraiu a atenção das sans-culottes defendendo leis para punir açambarcadores e especuladores, e Terror contra os inimigos do povo. Em 1793, as mulheres de Paris enviaram deputações à Sociedade Jacobina, à Comuna de Paris e à Convenção para ameaçar interferir com o recrutamento de sans-culottes se essas instituições não protegessem os seus interesses $^{322}$.

Em fevereiro de 1793 as revoltas de subsistência continuaram. Na ata de reunião da Sociedade Jacobina de 22 de fevereiro vemos que algumas cidadãs da Seção Quatre-Nations pediram aos jacobinos que emprestassem sua sala de reuniões para uma discussão sobre açambarcamento - eles recusaram dizendo que a sala já estava reservada. As espectadoras das galerias gritaram que os jacobinos abrigavam mercadores e açambarcadores que enriqueciam à custa da infelicidade pública. Mas a verdade é que eles eram contra o tabelamento de preços: "Dubois-Crancé, presidente da Convenção declarou que rejeitaria com horror qualquer petição de fixação de preços de alimentos" "C... disse que se as cidadãs usassem a sala, trinta mil mulheres poderiam fomentar a desordem em Paris" ${ }^{323}$. Os convencionais temiam o poder incendiário de mulheres revoltadas, e sabiam que a palavra das militantes podia atrair muitas seguidoras. $\quad$ O sentido de sua ação era a proteção das famílias e o bem comum. Elas se reuniram na sala cedida pela Sociedade Fraternal dos Dois Sexos sob o nome de Assembléia das Republicanas para redigir uma petição a ser apresentada na

\footnotetext{
321 idem, pp. 119-121.

322 idem, pp. 105-106.

${ }^{323}$ idem, pp. 126-127
} 
Convenção no dia 24 de fevereiro: "as mães e esposas dos defensores da Pátria estão (...) assustadas com as manobras dos açambarcadores" e "pedem (...) que o dinheiro seja declarado mercadoria". $\quad$ Enquanto isso, as lavadeiras tinham lido sua petição contra a carestia do sabão, que havia dobrado de preço em um mês; elas queriam a pena de morte para os açambarcadores e agiotas, os únicos responsáveis pela alta do sabão. Elas gritavam: "pão e sabão". Era domingo. Prudomme relatou em Révolutions de Paris, no. 190 de 25 de fevereiro de 1793 que a Convenção ouviu as duas petições friamente e adiou as decisões para terça-feira. As peticionárias retrucaram furiosas que elas voltariam na segunda-feira pois quando seus filhos pediam leite, elas não podiam "adiá-los para depois de amanhã" ${ }^{324}$. As militantes eram mães que precisavam alimentar os filhos. Os convencionais não levavam as ativistas a sério. Os jornalistas apresentaram as revoltas como uma manifestação feminina à qual se misturaram alguns provocadores homens vestidos de saias, e que "nem teriam tido a precaução de fazer a barba"325 . Os revoltosos não eram pilhadores de mercadorias, eles queriam que fossem distribuídas pelos açambarcadores a um preço justo, e a maioria fazia questão de pagar. A violência das mulheres era sobretudo verbal, por exemplo, ameaçavam enforcar os merceeiros e provocavam os guardas com insolência. Em geral eram os homens que arrombavam as portas dos armazéns e começavam a vistoria das mercadorias $^{326}$. Na véspera desses acontecimentos, Tallien disse que havia homens instigando a revolta nos faubourgs, e por isso havia mais gente na porta das padarias: " alguém quer uma rebelião e eu tenho provas" . Ele tentou conversar com as mulheres sobre o tabelamento do sabão, mas percebeu que "elas não eram patriotas, e sim instrumentos que os aristocratas manipulam" ${ }^{327}$. No dia seguinte, o depósito do atacadista Laurent Commard foi invadido por um grupo liderado por mulheres, que levaram o açúcar e café encontrados - várias insistiram em pagar o preço considerado "justo" ${ }^{328}$. Por sua vez, Robespierre, falando aos Jacobinos, também atribuiu a

\footnotetext{
${ }^{324}$ GODINEAU, Dominique, Citoyennes Tricoteuses - Les femmes du peuple à Paris pendant la Révolution Française, Paris, Editions Alinea, Perrin, 2004 , p. 125.

325 idem, p. 126.

${ }^{326}$ idem, p. 126.

${ }^{327}$ Ata da sessão da Convenção Nacional de 24 de fevereiro, 1793 - LEVY, Darline G., APPLEWHITE, Harriet B., JOHNSON, Mary D. - Women in Revolutionary Paris - 1789-1795 - . Selected documents translated with notes and commentary by the authors - Urbana e Chicago, University of Illinois Press, 1980 , pp. 129-130.

${ }^{328}$ Relatório de perdas e danos cometidos no depósito do Cidadão Commard, 26 de fevereiro, 1793, Seção dos Guardas Franceses, IN Arquivos da Prefeitura de Polícia de Paris, AA 153, nos. 78ff In LEVY, Darline G., APPLEWHITE, Harriet B., JOHNSON, Mary D. - Women in Revolutionary
} 
responsabilidade pelas revoltas aos "estranhos" e "intrigantes " ricos disfarçados de respeitáveis sans-culottes circulando entre cidadãos honestos. Tais conspiradores nunca mencionavam os contra-revolucionários da Convenção - os Girondinos - e acusavam os Jacobinos de lucrar com os monopólios! Para ele, os intrigantes queriam confundir o povo, incitá-lo à violência para assustar todos os proprietários - seu objetivo era provar que o sistema de liberdade e igualdade subvertia toda a ordem e estabilidade. Assim, Robespierre desqualificou a ação independente dos revoltosos atribuindo-a à conspiração contra-revolucionária ${ }^{329}$.

Os documentos acima revelam como as rebeliões combinavam antigos rituais, o badalar dos sinos para chamar vizinhos, por exemplo, com as práticas políticas das petições na Comuna, na Convenção, a reivindicação de pena de morte para especuladores, e a violência revolucionária da taxação popular. Para elas, o direito à existência precedia o direito de propriedade. As militantes expressavam suas opiniões francamente, não tinham "papas na língua", fosse qual fosse o interlocutor, bem ao espírito sans-culotte. Seu poder e ousadia cresciam à medida que as instituições se democratizavam e passavam cada vez mais para o controle das classes populares. As quarenta e oito Seções de Paris se declararam em "assembléia permanente" em julho de 1792. Os cidadãos passivos eram admitidos e tinham direito a voto, e as mulheres podiam freqüentar as galerias de espectadores ${ }^{330}$. Havia portanto, um contexto político favorável à cidadania militante das sans-culottes. As mulheres ameaçavam com traição política, quando falavam em atrapalhar o recrutamento - represália muito séria em tempo de guerra. Em meio à revolta de subsistência generalizada em Paris no início de 1792 e outra vez em 1793, essas ativistas começaram a se organizar num grupo feminino, a Assembléia das Republicanas, porque perceberam que assim teriam mais força. As autoridades não sabiam como lidar com elas: ora mostravam simpatia pelas privações que sofriam, ora frieza na hora de recusar as reivindicações, ora questionavam sua independência de decisão procurando "instigadores" estranhos ao grupo. O fato é que elas estavam no centro da crise econômica, na posição de vítimas;

Paris - 1789-1795 - . Selected documents translated with notes and commentary by the authors Urbana e Chicago, University of Illinois Press, 1980., pp. 133-137.

${ }^{329}$ GEORGE, Margaret, The "World Historical Defeat" of the Républicaines Révolutionnaires, Science \& Society, 40.4 (winter 1976-1977), pp. 410-437

${ }^{330}$ LEVY, Darline G., APPLEWHITE, Harriet B., JOHNSON, Mary D. - Women in Revolutionary

Paris - 1789-1795 - . Selected documents translated with notes and commentary by the authors Urbana e Chicago, University of Illinois Press, 1980, pp. 106-107. 
e no centro da agitação revolucionária como rebeldes às autoridades e já adversárias políticas dos Girondinos, e causando desconforto entre os Montanheses.

Nas províncias a crise econômica era também política: o clube feminino de Besançon agiu como grupo de pressão pelos controles dos preços do mercado, e o de Dijon se uniu ao clube masculino na petição à Assembléia Nacional na questão do uso do açúcar e café. Em Dijon as ativistas se rebelaram contra o prefeito que tinha caçoado de sua reivindicação de cereais mais baratos - o incidente resultou num confronto geral que levou ao afastamento do líder municipal e à eleição de outro candidato de compromisso. Em setembro de 1792, membros do clube feminino de Lyon denunciaram açambarcadores e monopolistas e estabeleceram preços de sessenta gêneros alimentícios e produtos essenciais, considerando que o preço tinha que ser baseado "na vontade do povo, justiça, eqüidade e igualdade". Ademais, organizaram patrulhas femininas para fiscalizar o cumprimento da tabela. Finalmente, pressionadas pela rebelião e mercados vazios, as autoridades locais e departamentais concordaram em baixar os preços e procurar os agitadores contra-revolucionários ${ }^{331}$. A visão econômica das ativistas não se separava da política, nem dos princípios da Revolução. As táticas eram o desafio aberto às autoridades, capacidade de atrair seguidores de ambos os sexos (caso da destituição do prefeito) e a disposição para o confronto. Fica a impressão de que estavam no centro dos acontecimentos, próximas ao poder e exercendo na prática - e con gusto - seus direitos de cidade.

\subsection{5 - A Sociedade das Cidadãs Republicanas Revolucionárias}

Em Paris, o ano de 1793 marcou o auge da influência política das mulheres das classes populares. Em parte isso se deve ao fato de que as instituições políticas eram cada vez mais lideradas pela sans-culotterie: os dirigentes eram os pais, maridos e companheiros das ativistas. Se fosse preciso, as Seções de Paris podiam funcionar como unidades militares e a Guarda Nacional que havia atirado no povo no Campo de Marte em 1791, agora era controlada pelo povo. As sociedades fraternais se tornaram mais populares e apelaram às mulheres para que tivessem um papel mais ativo,

\footnotetext{
${ }^{331}$ AN F73686 (6), Aviso das cidadãs de Lyon, setembro 1792 e outros docs. IN DESAN, Suzanne “Constitutional Amazons: Jacobin Women's Clubs in the French Revolution” IN Re-creating Authority in Revolutionary France, edited by Bryant T. Ragan, Jr.and Elizabeth A. Williams, New Brunswick, New Jersey, Rutgers University Press, 1992 , p23.
} 
elaborando petições, discutindo questões, defendendo o interesse das viúvas de guerra e soldados. Muitos dos oficiais da Comuna de Paris agora também vinham das classes populares, e eram, portanto, mais solidários em relação às dificuldades econômicas e reivindicações femininas nesse sentido ${ }^{332}$.

Em maio de 1793, Pauline Léon ${ }^{333}$ e Claire Lacombe $^{334}$ fundaram a Sociedade das Cidadãs Republicanas Revolucionárias, que já vinha funcionando informalmente desde fevereiro. Suas reuniões seriam na biblioteca dos Jacobinos, na Rue SaintHonoré. Quem eram os membros da nova Sociedade? Olwen Hufton alega que não se sabe nada sobre o número de associadas: uma estimativa fala em apenas 67 membros, Godineau relata que mais de cento e setenta compareceram à reunião inaugural, porém apenas cem vinham regularmente às sessões. As líderes declaravam o apoio de milhares e os Jacobinos acreditavam que seu programa de ação poderia, de fato, atrair as massas populares. Segundo Godineau, as informações sobre os membros são raras e incompletas. Conhecemos as profissões de dezenove Republicanas, as quais exerciam as atividades comuns entre as parisienses: pequeno comércio, costura, artesanato, prendas do lar, incluindo até o ramo de espetáculos. O nível de instrução variava: as dirigentes do clube eram mais educadas e escreviam bem, enquanto um terço das simples militantes sobre quem existem informações, era iletrada. Em geral, estas eram comerciantes de rua ou mulheres de artesãos. As líderes pertenciam à pequena burguesia, mas o clube recrutava e atraía mulheres das camadas mais populares, como as esposas e filhas de militantes sans-culottes e funcionários das Seções de Paris. Só há

\footnotetext{
${ }^{332}$ LEVY, Darline G., APPLEWHITE, Harriet B., JOHNSON, Mary D. - Women in Revolutionary Paris - 1789-1795 - . Selected documents translated with notes and commentary by the authors Urbana e Chicago, University of Illinois Press, 1980, pp. 106-107.

${ }^{333}$ GODINEAU, Dominique, Citoyennes Tricoteuses - Les femmes du peuple à Paris pendant la

Révolution Française, Paris, Editions Alinea, Perrin, 2004 , pp. 375-376. LÉON: Nasceu em Paris em 1768, fabricante e comerciante de chocolate junto com seus pais; casou em 1793 com o Enragée Leclerc, 18 dias depois da proibição dos clubes femininos. Sabia ler e escrever e teve uma educação relativamente cuidada. Participou de várias jornads revolucionários. Ela e o marido foram presos pelo Comitê de Segurança Pública em 14 germinal do ano II e libertados em fructidor - depois disso, seu nome desaparece dos arquivos.

${ }^{334}$ GODINEAU, Dominique, Citoyennes Tricoteuses - Les femmes du peuple à Paris pendant la Révolution Française, Paris, Editions Alinea, Perrin, 2004 , pp. 373-374. LACOMBE: Nasceu em Pamiers de pais comerciantes. Artista de teatro em Marselha, Lyon e Toulon, veio para Paris em julho de 1792, dedicou-se inteiramente à Revolução, vivendo de suas economias Oradora eloqüente, sabia escrever. Ganhou faixa e coroa cívica pela participação da jornada das Tulherias em agosto de 1792. Muito atacada pelos Jacobinos . Presa em germinal do ano II , ficou 15 meses na prisão, durante os quais suas amigas tentaram muitas vezes libertá-la. Ao recuperar a liberdade, voltou à vida de atriz e aos seus amores, e nunca mais se envolveu em política. No ano VI voltou a Paris com um companheiro de teatro. Endividou-se. Depois disso, não há mais informações sobre ela.
} 
informações sobre a faixa-etária de nove associadas: dois terços tinham entre 25 e 30 anos, e um terço entre 60 e 70 anos. Pode-se supor que, do ponto de vista das obrigações familiares, elas dispunham de tempo para o clube, pois algumas não eram mães, não tinham filhos em baixa idade ou já os haviam criado ${ }^{335}$. As atas de suas deliberações internas (reuniões da Sociedade ) se perderam ou foram destruídas pela polícia ou pelas próprias associadas que temiam seu possível uso pelas autoridades para incriminá-las ${ }^{336}$.

Pauline Léon e Claire Lacombe eram freqüentadoras assíduas das galerias da Assembléia Nacional, do clube dos Jacobinos, e Sociedade Fraternal dos Patriotas dos Dois Sexos, e outras associações populares, além de terem ambas participado armadas da jornada de 10 de agosto de 1792 que levou à queda da monarquia. Pauline Léon militou na Sociedade Fraternal ao lado de Louise Robert, jornalista respeitada, e Varlet, um dos Enragés; foi ali que conheceu seu futuro marido, o também Enragé Théophile Leclerc. Há certa continuidade de questões tratadas na Sociedade fraterna e na Sociedade das Republicanas Revolucionárias. A Sociedade fraterna queria que as tribunas fossem franqueadas ao público e pediram aos deputados jacobinos que suprimissem os lugares reservados, em janeiro de 1792. As Republicanas Revolucionárias chegaram a interditar fisicamente o acesso aos portadores de convites em 1793. Em 15 de maio de 1793, durante o conflito entre Girondinos e Montanheses, montavam guarda na entrada da Convenção rasgando os cartões de acesso dos convidados para a sessão. Théroigne de Méricourt, próxima dos Girondinos, insistia em utilizar o seu, e teve que ser salva por Marat das chicotadas aplicadas pelas militantes.

Em fevereiro de 1791, as irmãs da Sociedade Fraterna juraram não se casar com aristocratas, e em 1793 as Republicanas prometeram povoar a França com pequenos Marats ${ }^{337}$. Por sinal, muitas outras ativistas fizeram declarações semelhantes, como Marie Martin que discursou na Assembléia: "aquelas que juraram no altar da liberdade mantê-la com todo seu poder, só darão sua mão àqueles cujas

\footnotetext{
${ }^{335}$ GODINEAU, Dominique, Citoyennes Tricoteuses - Les femmes du peuple à Paris pendant la Révolution Française, Paris, Editions Alinea, Perrin, 2004 , p. 131.

${ }^{336}$ HUFTON, Olwen H., Women and the Limits of Citizenship in the French Revolution, Toronto, Buffalo, London, University of Toronto Press, 1992, pp. 28-29

${ }^{337}$ GUILLON, Claude, Pauline Léon, une républicaine révolutionnaire, AHRF no. 2, 2006
} 
virtudes cívicas sejam reconhecidas e professem os princípios gloriosos que todo bom patriota deve ter no coração" ${ }^{\text {338. }}$ Penso que tais afirmações - além de ilustrar situações de confusão entre vida pessoal e vida pública, típicas da ideologia revolucionária - são atos de civismo, proclamações de princípios republicanos: cidadãs patriotas não se casam com os inimigos. Era pouco provável que algum aristocrata pedisse em casamento uma militante radical, mas se aparecesse algum incauto, a resposta já estava dada de antemão. Na falta da cidadania oficial, as mulheres adotavam práticas que configuravam gestos de cidadania de facto, usando a criatividade: anunciavam sua lealdade à pátria em juramentos solenes e públicos, dessa forma inserindo-se no corpo político da nação.

O objetivo principal da Sociedade era defender a pátria e a Revolução, mas as cidadãs estavam livres para armar-se ou não. As revolucionárias anunciaram seus objetivos: instruir-se politicamente, aprendendo a Constituição e as leis da República, participar dos assuntos cívicos, e socorrer as vítimas de atos arbitrários, seguindo a linha moderada de outros clubes femininos . Mas, ao apresentaram-se no clube dos Jacobinos no dia 12 de maio numa deputação mista com os Cordeliers, foram mais radicais: agora reclamavam a prisão dos Girondinos e outros suspeitos, tribunais revolucionários nos departamentos e Seções, aumento do exército revolucionário de Paris para quarenta mil homens, distribuição de terras aos soldados e imposto sobre os ricos para os pobres poderem comprar pão. Além disso queriam a exclusão dos nobres de todos os empregos públicos, principalmente o de oficiais do exército. Como fica bem claro, as Republicanas Revolucionárias não tinham uma agenda feminista; suas propostas se integravam no programa radical da sans-culotterie em geral. O regulamento de julho era mais moderado: o artigo XV dos estatutos traz o juramento obrigatório dos novos membros: “ Juro viver pela República ou morrer por ela; prometo ser fiel à Regra da Sociedade enquanto ela existir”339. A preocupação com a virtude republicana estava presente: “A Sociedade, acreditando que o povo só deveria se unir para honra mútua, apoio, e incentivo à virtude, decreta que receberá em seu meio apenas

\footnotetext{
338 Le Patriotisme des Dames Citoyennes - discours prononcé à la Tribune de l'Assemblée Patriotique - Marie Martin, ano segundo da liberdade - Cahiers de doléances des femmes en 1789 et autres textes - préfacé par Paule-Marie Duhet - Paris, C. Des femmes 1981, p. 96.

${ }^{339}$ Règlement de la Société des citoyennes républicaines révolutionnaires de Paris (n.p.,n.d.), Bibliothèque Historique de la Ville de Paris, 958939. LEVY, D., BRANSON APPLEWHITE, H., JOHNSON, M. - Women in Revolutionary Paris - 1789-1795 - . Selected documents translated with notes and commentary by [the authors] - University of Illinois Press, pp.161-165.
} 
aquelas cidadãs de bons costumes (“bonnes moeurs”)- esta é a condição mais essencial para a admissão, e a sua ausência, a principal causa da exclusão” ${ }^{340}$. Olwen Hufton afirma que o objetivo expresso do Clube das Cidadãs Republicanas Revolucionárias era o combate ao açambarcamento e à inflação, questões críticas para os sans-culottes 341. Mas a documentação existente mostra que, pelo menos no início, o programa de ação incluía objetivos políticos, sociais e econômicos.

Dentro da preocupação com a moral e os bons costumes, a Sociedade das Revolucionárias Republicanas sugeriu à Convenção que prendesse todas as prostitutas, não como medida de saúde pública, mas para garantir a segurança política, porque temia-se que ajudassem a contra-revolução. Um programa de reabilitação seria instituído e ministrado em abrigos nacionais onde as antigas prostitutas aprenderiam ofícios apropriados para mulheres - depois de regeneradas, retornariam à sociedade para tornarem-se mães. Olympe de Gouges e alguns clubes femininos também haviam proposto uma regulamentação para aquela atividade, em nome da luta contra a libertinagem. A prostituição foi proibida em 1793 e 1794, e as suspeitas presas em grande número. Depois da morte de Robespierre, o comércio do sexo recobrou seu antigo vigor $^{342}$. Deve-se lembrar que essas mazelas sociais envergonhavam os líderes revolucionários, pois a Revolução queria extirpar o que considerava ranço dos vícios do Antigo Regime. Aos olhos Jacobinos, a existência de prostitutas, mendigos, crianças abandonadas equivaliam a uma acusação de incompetência. Eram males que podiam solapar as bases da República, pois a moral privada dos indivíduos afetava o bem comum. Assim, as propostas das Republicanas Revolucionárias podiam ser consideradas patrióticas. Todos aqueles que, pela sua própria presença, eram um embaraço à República, eram considerados "perigosos" porque supostamente eram manipulados pelos inimigos. Um relatório de polícia de 19 de setembro de 1793 atesta o que pensava a liderança jacobina a respeito: " os mendigos formam uma classe excessivamente perigosa; são pagos pelos aristocratas para pedir esmolas aos patriotas;

\footnotetext{
340 idem, p. 163.

${ }^{341}$ HUFTON, Olwen H., Women and the Limits of Citizenship in the French Revolution, Toronto, Buffalo, London, University of Toronto Press, 1992, p. 2

${ }^{342}$ HUNT, Lynn, The Family Romance of the French Revolution , Los Angeles, University of California Press, 1992 , pp. 159-160.
} 
é necessário subtrair esses infelizes dos olhares públicos, pois sua visão é assunto de censura à República na boca dos mal-intencionados"343.

Finalmente, as militantes queriam a formação de "companhias de amazonas" armadas para lutar contra os inimigos internos, enquanto os homens combatiam nas fronteiras. Note-se aqui a transposição dos papéis masculinos e femininos na família para a arena política. Tradicionalmente, os homens se ocupavam de atividades “externas” ao lar, enquanto as esposas cuidavam das "internas”. Godineau ressalta que elas foram as únicas militantes a formularem esta concepção profundamente original além disso , a nação era a grande família dos cidadãos e as mulheres teoricamente não estavam saindo de seu papel de guardiãs do $\operatorname{lar}^{344}$. Elas se apresentavam batendo tambor, bandeira desfraldada com o olho da vigilância, um dos símbolos republicanos, usando o barrete frígio da liberdade na cabeça e algumas vestidas de amazonas. Para proteger a nação e prender os suspeitos teriam que andar armadas. Não obstante, as Republicanas Revolucionárias nunca formaram um corpo verdadeiramente armado. Dois dias antes de sua supressão, tinham apenas quatro piques, de valor mais simbólico que bélico, o que permite supor que teriam renunciado à pretensão original. Em compensação, não renunciaram ao objetivo de salvar a pátria e se engajar politicamente no movimento revolucionário ${ }^{345}$.

Na primavera de 1793, as Republicanas Revolucionárias se aliaram aos Montanheses contra os Girondinos. Uma vez instaurada a República, um dos aspectos da luta de poder girava em torno da pressão radical dos sans-culottes sobre a Convenção. Robespierre, Saint-Just, Marat, Danton, Desmoulins tinham um projeto social vizinho ao da sans-culotterie, e queriam uma aliança com as massas populares, julgando que esse seria o meio de assegurar a vitória de uma revolução que beneficiasse a todos. O povo era a favor do tabelamento de preços, controle do abastecimento de gêneros, e do Terror, que envolvia a prisão e execução dos inimigos

\footnotetext{
343 Paris pendant le Terreur - Rapports des Agents Secrets du Ministre de L'Intérieur publicados por CARON, Pierre (autor da Introdução) - Tome Premier, 27 Août 1793 - 25 Décembre 1793, Paris , Librairie Alphonse Picard et fils, 1910, p. 146.

${ }^{344}$ GODINEAU, Dominique, Citoyennes Tricoteuses - Les femmes du peuple à Paris pendant la Révolution Française, Paris, Editions Alinea, Perrin, 2004 , 131-132.

345 GODINEAU, Dominique, Citoyennes Tricoteuses - Les femmes du peuple à Paris pendant la Révolution Française, Paris, Editions Alinea, Perrin, 2004 p.132-133.
} 
suspeitos. No mês de maio, as Republicanas Revolucionárias passaram a freqüentar diariamente os relatórios de polícia por suas atividades - tal interesse maciço e repentino reflete a importância de sua atuação no conflito entre Girondinos e Montanheses. O observador de polícia Terrasson observou que as Republicanas Revolucionárias eram o elemento motor da oposição anti-girondina: "as mulheres (...) querem a demissão dos vinte e dois deputados Girondinos. Elas têm a esperança de serem secundadas pelos homens". $\quad$ De fato, as Republicanas concorreram para preparar a insurreição contra os Girondinos, fazendo propaganda, discursando, promovendo agitações na Convenção, nos clubes políticos, nas Seções. No dia 2 de junho de 1793, a Convenção ordenou a prisão de vinte e nove deputados Girondinos. Gorsas relatou que os membros do Comité insurrecional eram apoiados por "uma tropa de mulheres dizendo-se revolucionárias, tropas de fúrias, ávidas de carnificina armadas, essas mulheres sem pudor retinham cativos os deputados, um dos quais foi perseguido por cinco ou seis dessas megeras, e teve que saltar de uma janela". Gorsas as chamou de "bacantes de Marat”, “megeras”, e denunciou que "elas querem fazer rolar as cabeças e se embebedar de sangue” ${ }^{346}$. O fantasma das mulheres armadas até os dentes é repetido por outros Girondinos, como Bergoering e Lanjuinais, com uma insistência que ultrapassa a realidade e beira o delírio, na opinião de Godineau. A autora considera que as acusações desses deputados têm o objetivo de assustar os leitores com o aspecto "horrível, anárquico e indecente" dos armamentos femininos, que se resumiam a alguns instrumentos de trabalho ou facas que algumas traziam nos bolsos - o medo masculino desarrazoado estaria no terreno das mentalidades $^{347}$. Entre as parisienses que invadiram a Assembléia Nacional na noite de 5 de outubro de 1789, algumas portavam facas na cintura, o que causou a mesma repulsa entre os deputados e comentários negativos na imprensa.

As Republicanas foram consideradas uma das principais forças do movimento popular naquele verão de 1793, tanto pelos deputados Girondinos prescritos, como pelos observadores da polícia e autoridades revolucionárias. Aquele foi o período em que as autoridades jacobinas aceitaram com maior indulgência e até incentivaram a

\footnotetext{
346 GORSAS, Précis rapide des événements qui ont eu lieu à Paris dans les journées des $\mathbf{3 0}$ et $\mathbf{3 1}$ mai, preier et 2 juin 1793 IN LEVY, Darline G., APPLEWHITE, Harriet B., JOHNSON, Mary D. Women in Revolutionary Paris - 1789-1795 - . Selected documents translated with notes and commentary by the authors - Urbana e Chicago, University of Illinois Press, 1980, p. 154-155. ${ }^{347}$ GODINEAU, Dominique, Citoyennes Tricoteuses - Les femmes du peuple à Paris pendant la
} Révolution Française, Paris, Editions Alinea, Perrin, 2004 pp. 138-139. 
participação feminina no movimento popular. O Departamento de Paris e os comissários das seções que dirigiram a insurreição contra os Girondinos elogiaram especialmente o zelo, a audácia e a coragem das Republicanas Revolucionárias naquele conflito. Tais declarações vão além das circunstâncias: são uma afirmação do direito e até do dever das mulheres de participarem ativamente da Revolução. "As Republicanas Revolucionárias (...) desprezam as roupas e seus diamantes são as cocardas , seu lugar é embaixo da bandeira tricolor, suas danças são em volta do altar da pátria, todos os seus cantos celebram a liberdade e seus entusiasmos mais vivos são pela República"; elas sentem um "amor imenso" que não pode ficar restrito ao privado:" esposas e mães republicanas, seus lares não conseguem conter a abundância de suas afeições". Entretanto as autoridades lhes lembraram que deviam desdenhar do poder das armas e preferir o "império supremo da persuasão" que a natureza lhes havia dado. Os oradores reconheceram nas Republicanas qualidades femininas, por exemplo, o poder que tinham de convencer pela palavra. E concederam que o seu papel na Revolução ia além da maternidade: como militantes, elas podiam desfazer conspirações e defender a pátria em Revolução, pois tinham amor à República e ao gênero humano ${ }^{348}$.

As cidadãs da Seção Droits de l'homme apresentaram às Republicanas Revolucionárias um estandarte contendo a Declaração dos Direitos do homem e do Cidadão onde, além de elogiar a coragem das cidadãs, apontam a combinação dos deveres maternos e públicos das patriotas: ${ }^{349 "}$ as mulheres têm como primeira obrigação seus deveres de (...) esposas e mães; (...) mas é possível reconciliar o que a natureza exige com o amor ao bem público. Depois de cuidar de suas obrigações indispensáveis, (...) as mulheres citoyennes das sociedades fraternais se consagram à vigilância e instrução e têm a satisfação doce de serem duplamente úteis" ; "coragem, perseverança, bravas Republicanas" . Aqui vê-se que as Republicanas tinham aliadas entre as militantes das Seções de Paris; também fica clara a preocupação de não

\footnotetext{
${ }^{348}$ GODINEAU, Dominique, Beauté, respect et vertu: la séduction est-elle républicaine? (17701794), DAUPHIN, Cécile, FARGE, Arlette (direction) Séduction et Sociétés, Paris, Seuil, 2001, pp. 115-116.

${ }^{349}$ Discours prononcé à la Société des citoyennes républicaines révolutionnaires, par les citoyennes de la Section des Droits de l'homme en lui donnant un guidon sur lequel est la Déclaration des droits de l'homme (n.p., n.d.) IN LEVY, Darline G., APPLEWHITE, Harriet B., JOHNSON, Mary D. - Women in Revolutionary Paris - 1789-1795 - . Selected documents translated with notes and commentary by the authors - Urbana e Chicago, University of Illinois Press, 1980, pp. 176-7.
} 
dissociar o ativismo político dos deveres maternos, qualidade essencial em todas as mulheres na ideologia revolucionária, e escudo de proteção contra maledicências.

Havia porém um limite para essa participação feminina. Em época de crise, notadamente naquele verão de 1793, as mulheres podiam deixar as galerias das Seções e se misturar com os cidadãos e às vezes até votar com eles, mas no final tinham que voltar aos seus lugares - no fundo, não eram consideradas membros plenos da assembléia geral. No dia 31 de maio, as Republicanas Revolucionárias pediram para participar do Comité Insurrecional, e ouviram uma recusa: não se tratava de envolvimento de clubes, mas sim de uma reunião de deputados de quarenta e oito Seções, "emanação do Povo Soberano", do qual depreende-se que elas não faziam parte. 350 . No dia 2 de junho, na Convenção, elas não estavam no meio dos insurretos, mas num grupo separado, e tiveram que apresentar uma petição separada para se fazerem ouvir. Percebe-se que as ativistas eram coadjuvantes da ação, mas não eram admitidas na estrutura oficial do poder revolucionário.

As militantes porém encontraram outros modos de demonstrar seu pertencimento ao Povo Soberano. No dia 24 junho de 1793 a nova Constituição foi aprovada e submetida a um referendo ${ }^{351}$. As cidadãs não queriam ser excluídas desse processo nacional e , apesar de não terem direito a voto, se uniram aos homens das assembléias primárias na aprovação por aclamação, ou votaram em escrutínio particular quando havia chamada nominal. Depois prestaram juramento à Constituição. No dia 2 de julho, cortejos imensos de parisienses felicitaram a Convenção pela nova Carta - as mulheres eram numerosas e em geral tinham uma participação que Godineau chamou de "ornamental": jogando flores, oferecendo coroas cívicas, aceitando cumprimentos do presidente. Sua presença, entretanto, era importante para realçar a unidade da nação em torno do governo republicano, e acho que nesse sentido , pode-se usar o termo "cidadania ornamental" , ou seja, uma ação que não acarretava exercício de

\footnotetext{
350 GODINEAU, Dominique, Masculine and Feminine Political Practice during the French Revolution, 1793 - Year III IN APPLEWHITE, Harriet B. \& LEVY Darline G. (edited by) Women \& Politics in the Age of the Democratic Revolution, Ann Arbor, The University of Michigan Press, 1993, kates
}

${ }^{351}$ GODINEAU, Dominique, Citoyennes Tricoteuses - Les femmes du peuple à Paris pendant la Révolution Française, Paris, Editions Alinea, Perrin, 2004 , pp. 143-145. 
direitos políticos, mas que tinha uma importância simbólica não desprezível. Muitos homens gostariam que as mulheres se limitassem a esse tipo de papel cívico, mas elas não se contentavam com a passividade. Algumas pediram aos oradores de sua Seção que transmitissem a seguinte mensagem na Convenção: " se a natureza de seu sexo não lhes permite votar, elas não podem ficar insensíveis aos sentimentos republicanos que seus esposos, irmãos e amigos vinham exprimir", e por sua vez aceitavam a Declaração dos Direitos do Homem e a Constituição. A maioria parecia mais preocupada em anunciar sua vontade republicana que exigir o direito ao voto. Uma cidadã da Seção do Beaurepaire, entretanto, expressou indignação pela exclusão feminina do sistema político " (...) como a Constituição repousa sobre os Direitos do Homem, nós reclamamos hoje o seu inteiro exercício". Cem Cidadãs Republicanas Revolucionárias participaram do cortejo oficial de 24 de junho carregando suas bandeiras, marchando atrás dos líderes do desfile.

Os clubes femininos das províncias também se manifestaram nessa ocasião: o de Besançon tomou posição contra o federalismo, assim como os clubes de Bordeaux, neste caso para conseguir sobreviver à queda política dos Girondinos e evitar a própria supressão. Segundo o estudo de Suzanne Desan ${ }^{352}$ estas associações femininas, juntamente com as de Damazan, Clermont-Ferrand, Le Mans, Nancy e Beaumont, votaram aceitar a Constituição e enviaram seus endossos à Convenção Nacional no verão de 1793. A aceitação da Carta constitucional, no entanto, levantou a questão dos direitos políticos das mulheres, e vários clubes e indivíduos aproveitaram a ocasião para expressar sua frustração com o estatuto cívico feminino. As sócias dos clubes de Nancy, Le Mans e Beaumont repreenderam a Convenção por negar-lhes o direito ao voto ou à ratificação do ato que elas tinham apoiado tão decididamente, sendo que o de Beaumont havia apelado ao direito de voto em fevereiro de 1793. Uma jovem de vinte e dois anos, e mãe de quatro filhos, Elisabeth Lafaurie, já em 1791 tinha feito um discurso no clube Jacobino masculino de Saint-Sever-Cap declarando que era injusto negar às mulheres uma voz política "porque elas estão sujeitas às Leis que não puderam aprovar ou recusar, o que é contrário à liberdade (...)".

\footnotetext{
${ }^{352}$ DESAN, Suzanne - “Constitutional Amazons: Jacobin Women’s Clubs in the French Revolution” IN Re-creating Authority in Revolutionary France, edited by Bryant T. Ragan, Jr.and Elizabeth A. Williams, New Brunswick, New Jersey, Rutgers University Press, 1992 , pp.24-25.
} 
Poucas foram as vozes que reclamaram a igualdade cívica, porém já mais numerosas aquelas que apontaram a exclusão feminina dos direitos políticos, como atestam os exemplos acima. Impressiona a quantidade de militantes e associações que votaram simbolicamente a aprovação da Constituição de 1793 - transformando um ato privado em público - como uma maneira de se inscrever no corpo político da nação. O voto não tinha nenhum valor legal, mas ao comunicá-lo solenemente aos legisladores, as ativistas revelaram sua vontade de pertencer ao Povo Soberano, embora oficialmente estivessem excluídas do corpo eleitoral. Através desta prática de cidadania, na verdade estavam exercendo um direito que não lhes cabia por lei ${ }^{353}$.

Em setembro de 1793, as Republicanas estavam próximas das idéias políticas dos Enragés - Léclerc, Jacques Roux e Varlet - grupo de revolucionários extremistas, cuja ação se situou entre fevereiro e setembro de 1793. O povo escutava quem propunha remédios mágicos contra a carestia e a especulação monetária, e apoiou os Enragés nos apelos à expulsão dos Girondinos, punição aos açambarcadores e agiotas. Jacques Roux, o "padre vermelho" era amigo do povo, e assim se dirigia às mulheres: "A vitória é certa quando as mulheres se misturam aos sans-culottes". Roux incentivou as taxações forçadas impostas pelos grupos populares aos comerciantes de velas, sabão e açúcar em fevereiro de 1793: " Acho que os merceeiros estão apenas restituindo ao povo o que vinham cobrando a mais há muito tempo"354. Por sinal, Marat foi contra a idéia da taxação forçada das mercadorias, dizendo que aqueles que impusessem tais medidas à Convenção deveriam ser perseguidos como perturbadores da tranqüilidade pública $^{355}$. Leclerc era adorado pelas revolucionárias e se casou com Pauline Léon depois de um breve romance com Claire Lacombe. Não era menos radical que os outros dois Enragées. Em 26 de agosto, um grupo de Revolucionárias leu uma petição, republicada no jornal de Leclerc, para uma assembléia hostil, exigindo a execução de "toda a Constituição e nada além da Constituição". Elas queriam a renovação de todas as autoridades constituídas, inclusive as da Convenção - Pauline Léon se apoiava na afirmação de Rousseau que "a prolongação dos poderes é freqüentemente o túmulo da

\footnotetext{
353 GODINEAU, Dominique, Citoyennes Tricoteuses - Les femmes du peuple à Paris pendant la Révolution Française, Paris, Editions Alinea, Perrin, 2004, p. 145.

${ }^{354}$ RICHET, Denis, "Enragés", IN FURET/OZOUF, Dictionnaire Critique de la Révolution

Française, Acteurs, Champs, Flammarion, 1992, pp.331-339.

${ }^{355}$ RICHET, Denis, "Enragés", IN FURET/OZOUF, Dictionnaire Critique de la Révolution

Française, Acteurs, Champs, Flammarion, 1992, pp.337.
} 
liberdade". "Mostrem-nos que esta Constituição, que nós acreditamos aceitar, existe e deve fazer nossa felicidade(...) é necessário que o povo sinta seus benefícios (...) cremos que a ambição reina nos seus comitês; organizem o governo segundo a Constituição (...) Vocês aprovaram um decreto pelo qual os suspeitos serão presos, mas esta lei não é derrisória quando são os próprios suspeitos que as devem executar?" ${ }^{356}$. Elas ousavam atacar diretamente os deputados da Convenção, provocando desconforto no governo. Esta petição das Republicanas marcou sua volta à cena política, depois de seu projeto de construção de um obelisco a Marat. Única petição dessa Sociedade que sobreviveu na íntegra, foi considerada muito significativa por Albert Soboul ${ }^{357}$. O programa ali delineado está próximo dos anseios da sans-culotterie em geral e é semelhante ao dos Enragés e Cordeliers: a luta contra o "inimigo interno", contra quem elas reivindicam uma série de medidas terroristas, como a destituição dos nobres, organização de tribunais revolucionários, julgamento de aristocratas e de Maria Antonieta.

Os Enragés e a Sociedade das Republicanas Revolucionárias atiçavam a cólera popular e acusavam a Convenção de imobilismo. Leclerc se atribuiu o mérito pela queda dos Girondinos e queria uma repressão ainda mais sanguinária. Clamou pela execução dos Girondinos derrotados dizendo: "Por que [os Srs.] têm medo de algumas gotas de sangue?" ${ }^{358}$. Foi expulso dos Jacobinos e preso. Varlet exigia o confisco de bens dos agentes da desigualdade econômica, entre eles, os açambarcadores e agiotas. Foi detido e passou dois meses na prisão. Jacques Roux trovejava contra a inércia da Convenção: “ (...) A igualdade não passa de um fantasma quando o rico, através do monopólio, exerce o direito de vida e morte sobre seu semelhante. Anunciem suas decisões. Os sans-culottes farão cumprir vossos decretos com suas piques”359. Robespierre denunciou Roux aos Jacobinos, que o taxaram de contra-revolucionário e o responsabilizaram pelas revoltas do sabão em fevereiro de 1793.

\footnotetext{
${ }^{356}$ Petição das Cidadãs Republicanas Revolucionárias IN L'ami du Peuple, par Leclerc, de Lyon, 30 agosto, ano 2 da República., no. XvII. New York Public Library, seção micro-fichas.

${ }^{357}$ SOBOUL, Albert, Les sans-culottes parisiens..... p. 150 citado por GODINEAU, Dominique, Citoyennes Tricoteuses - Les femmes du peuple à Paris pendant la Révolution Française, Paris, Editions Alinea, Perrin, 2004 , p. 157.

${ }^{358}$ RICHET, Denis, "Enragés", IN FURET/OZOUF, Dictionnaire Critique de la Révolution Française, Acteurs, Champs, Flammarion, 1992, p. 335.

${ }^{359}$ LEFEBVRE, Georges - La Révolution Française - Presses Universitaires de France, Paris, 1989, p. 344.
} 
As ativistas mantinham laços estreitos entre o clube e o movimento sansculotte parisiense: queriam um executivo sob controle popular e pensavam que só o povo não é corrupto, por isso digno de confiança. Enquanto o dirigente Vincent confiava aos comitês revolucionários a vigilância dos administradores, as Cidadãs Republicanas Revolucionárias queriam atribuir essa função diretamente ao povo soberano de cada Seção. Para elas, os funcionários públicos demissionários teriam que apresentar as contas de sua gestão e até a aprovação das mesmas ficariam detidos. Essa era a visão de poder da sans-culotterie, que favorecia a autonomia das Seções em relação às autoridades constituídas ${ }^{360}$. Patrice Higonnet observa que os sansculottes compreendiam mal a delegação do poder. Seu instinto os levava à ação direta e violenta. A pique é o símbolo do militante em marcha, e os canhões das Seções, o signo fetichista de sua soberania ${ }^{361}$. Naquela ocasião, o federalismo ainda representava um perigo para a Revolução e o governo de Paris não podia se permitir a pulverização de sua autoridade . Ora, a autonomia das Seções era uma ameaça à hegemonia Jacobina. A hostilidade do governo em relação aos princípios da democracia direta e a todos aqueles que a defendiam, oferece uma explicação política para a supressão da Sociedade das Republicanas.

A situação era perigosa: a República precisava da energia dos sans-culottes, mas o ardor popular nada podia sem um governo que o disciplinasse. Ademais, a cooperação da burguesia era imprescindível, pois era este o grupo social que fornecia os dirigentes; a salvação da Revolução dependia da união do Terceiro Estado ${ }^{362}$. A Convenção simbolizava a união do Terceiro Estado e era a única autoridade que se impunha a todos os patriotas. A aliança com as massas populares urbanas foi paga ao preço da Lei do Máximo em 29 de setembro de $1793^{363}$, embora os Jacobinos fossem

\footnotetext{
${ }^{360}$ GODINEAU, Dominique, Citoyennes Tricoteuses - Les femmes du peuple à Paris pendant la Révolution Française, Paris, Editions Alinea, Perrin, 2004 p. 159.

361 HIGONNET, Patrice - "Sans-culottes" IN FURET, Francois, e OZOUF, Mona, Dictionnaire Critique de la Révolution Française: Institutions et Créations, Événements, Idées, Acteurs Champs, Flammarion 1992

${ }^{362}$ LEFEBVRE, Georges - La Révolution Française - Presses Universitaires de France, Paris, 1989, p. 345.

${ }^{363}$ TULARD, J., FAYARD, J.F., FIERRO, A. - Histoire et dictionnaire de la Révolution Française 1789-1799. Ed. Robert Laffont, 1988. Verbete MAXIMUM (resumido): A primeira Lei do Máximo, votada em 4 de maio de 1793, fixou um preço máximo de venda para o trigo e a farinha, com valor estabelecido por cada administraçao departamental. A segunda Lei do Máximo, votada em 29 de setembro de 1793 era mais abrangente: impunha um valor máximo para grande número de gêneros de primeira necessidade, mas também para os salários. Essas leis foram revogadas em 24 de dezembro de 1794. Georges LEFEBVRE explica que tal legislação se inseria no programa da economia dirigida IN
} 
partidários da liberdade econômica ${ }^{364}$. E $\quad$ o Terror entrou na ordem do dia. Assim, o governo implementou as principais exigências dos Enragés, conservando a sua própria autoridade enquanto neutralizava e afastava os três radicais. Faltava agora tratar das Republicanas Revolucionárias.

Apesar da influência exercida pelos Enragés, principalmente Leclerc, sobre as Republicanas, Dominique Godineau não concorda com a visão comum na historiografia , que vê o clube das militantes femininas simplesmente como uma ramificação dos Enragés. Estes eram favoráveis ao componente feminino do movimento popular, e valorizavam as intervenções das ativistas, o que facilitou a aproximação entre eles. Apesar dessa constatação e dos laços pessoais que uniram Leclerc às duas principais líderes da sociedade feminina, Godineau acha que não se pode reduzir a independência política das Republicanas Revolucionárias por conta do amor ou fascínio exercido por um homem que teria conduzido suas ações, e pensado por elas. A autora aponta as ações conjuntas das Republicanas com os militantes secionarios, que marcaram toda a atividade externa do clube, da fundação à extinção. Enquanto Jacques Roux e Varlet agiam apenas na Seção onde residiam, as Republicanas moravam em bairros diferentes e agiam como grupo de mulheres em várias Seções de Paris. Quando elas deixaram de ser bem-vindas no clube dos Jacobinos e dos Cordeliers, continuaram mantendo boas relações e assistência mútua com os militantes secionarios. Outra observação pertinente a esse propósito é a falta de unidade política do próprio clube das Republicanas Revolucionárias, que abrigava várias tendências em seu meio. Sendo a única associação política feminina em Paris, reunia partidárias de Robespierre, dos Cordeliers, de Hébert e dos Enragés. A tendência Enragée de Claire Lacombe só se impôs à custa da expulsão de alguns membros ${ }^{365}$ e provou ser

La Révolution Française - Presses Universitaires de France, Paris, 1989, p. 351. FURET considera que o parêntese da Lei do Máximo e da economia dirigida "deixou uma grande lembrança, (...) pela intenção de proteger os humildes , os pobres e talvez prejudicar os ricos. Não importa que ela estivesse na origem de uma administração em grande parte ineficaz, cara e tirânica. O que conta sobretudo foi haver manifestado a ambição de ultrapassar a própria Revolução, procurando estender o princípio da igualdade às condições reais da vida dos homens" IN verbete Maximum , "Institutions et Créations", FURET, Francois, e OZOUF, Mona, Dictionnaire Critique de la Révolution Française: Institutions et Créations, Événements, Idées, Acteurs - Champs, Flammarion 1992

364 LEFEBVRE, Georges - La Révolution Française - Presses Universitaires de France, Paris, 1989, p. 382.

${ }^{365}$ Há um relatório interno das Republicanas Revolucionárias contendo críticas e acusações de três membros do clube contra Claire Lacombe e a direção da Sociedade, e apoiando as políticas de Robespierre, IN LEVY, Darline G., APPLEWHITE, Harriet B., JOHNSON, Mary D. - Women in 
politicamente desastrosa para a organização. Essas divisões internas enfraqueceram o clube, que não resistiu aos primeiros ataques ${ }^{366}$.

\subsection{6 - A guerra das cocardas}

A atitude dos grandes clubes como os Jacobinos e Cordeliers e alguns convencionais em relação às Republicanas Revolucionárias mudou durante o verão de 1793: calorosa em junho, reservada em julho e agosto e abertamente hostil em setembro $^{367}$. A desconfiança em relação a elas foi crescendo à medida que exerciam, junto com outros grupos radicais, uma pressão política maciça sobre as Seções, sociedades populares, o clube Jacobino e a Convenção. A ação vigorosa produziu a legislação desejada em setembro: dia 5, o terror legal entrou na ordem do dia; dia 9, foi criado um exército revolucionário; dia 17, aprovada a Lei dos Suspeitos; dia 29/30, a Lei do Máximo que estabelecia controles de preços uniformes para gêneros de primeira necessidade; e no dia 21 de setembro , a lei que tornava obrigatório, também para as mulheres, o uso da cocarda (ou roseta) tricolor. Uma vez aprovadas essas leis, as militantes queriam fiscalizar o seu estrito cumprimento ${ }^{368}$.

Já havia uma lei (3 de abril de 1793) obrigando os patriotas a usarem a cocarda nacional, mas o preceito legal era vago quanto à inclusão feminina. A questão serviu de pretexto para o enfrentamento entre moderadas e extremistas. Todos os membros da Sociedade das Republicanas Revolucionárias ostentavam suas cocardas em sinal de inequívoco patriotismo: usar a roseta tricolor significava pertencer ao corpo político da nação - era um distintivo de cidadania. O clube dos Cordeliers concordava que "as cidadãs que compartilham nossos trabalhos devem igualmente partilhar essa vantagem (uso da cocarda)". A Société Fraternelle de l'Unité, as Republicanas Revolucionárias, as sociedades mistas do Pont-Neuf, e a dos Amis-de-la-Patrie, os Jacobinos, e mais vinte e oito Seções aderiram à petição pela obrigatoriedade da

Revolutionary Paris - 1789-1795 - . Selected documents translated with notes and commentary by the authors - Urbana e Chicago, University of Illinois Press, 1980, PP. 178-181.

${ }^{366}$ GODINEAU, Dominique, Citoyennes Tricoteuses - Les femmes du peuple à Paris pendant la Révolution Française, Paris, Editions Alinea, Perrin, 2004 , pp. 154-156.

${ }^{367}$ GODINEAU, Dominique, Citoyennes Tricoteuses - Les femmes du peuple à Paris pendant la Révolution Française, Paris, Editions Alinea, Perrin, 2004 , p. 153.

${ }^{368}$ LEVY, Darline G., APPLEWHITE, Harriet B., JOHNSON, Mary D. - Women in Revolutionary

Paris - 1789-1795 - . Selected documents translated with notes and commentary by the authors Urbana e Chicago, University of Illinois Press, 1980, pp. 146-148. 
cocarda para as mulheres.

No entanto, aquelas que a usavam expunham-se às críticas de homens e mulheres que repudiavam a presença feminina na política, principalmente nas vertentes mais radicais. Membros femininos da Seção Pont-Neuf se queixaram de maus-tratos por parte de outras mulheres nas ruas. Cidadãs da Seção de l'Unité enfrentaram as vendedoras de peixe , as quais não queriam nem ouvir falar em cocardas e diziam: "só as vagabundas (putains) e as jacobinas usam - e as mulheres só devem se ocupar de sua casa e não dos acontecimentos". As rixas se multiplicaram: algumas apanhavam por usar, outras eram perseguidas por não usar. Há um documento manuscrito, de 13 de setembro de 1793, que ilustra a irritação dos observadores de polícia a esse respeito: " As cidadãs do Faubourg Saint-Germain quase todas adotaram a cocarda, e ameaçam aquelas que não as portam, e quando por acaso aparecem cidadãs de outros bairros que vêm tratar de seus afazeres ali, são ameaçadas". $\mathrm{O}$ autor do relatório pensa que para evitar as brigas, seria útil ordenar o uso ou a dispensa da cocarda ${ }^{369}$. As comerciantes do mercado, por sua vez, passaram a arrancar os barretes frígios enfeitados com a roseta tricolor da cabeça das militantes que os usavam. A Convenção finalmente cedeu e tornou o seu uso obrigatório, sob pena de prisão. O relatório do observador de polícia Latour-Lamontagne ${ }^{370}$ (21 de setembro) alerta para os complôs ocultos na fermentação das mulheres: " mesma fermentação sobre a questão da cocarda, especialmente entre as comerciantes da Halle. É um pomo de discórdia que os mal-intencionados jogaram entre nós; eles inspiram nas mulheres o desejo de compartilhar os direitos políticos dos homens. Quando elas tiverem a cocarda, dizem eles, vão exigir cartas cívicas, votar nas assembléias, (...) postos administrativos, e desse conflito de interesses e opiniões resultará uma desordem favorável aos nossos projeto. Temos no entanto que fazer justiça às mulheres: em geral elas testemunham o mais profundo respeito pela representação nacional (...) Mas, ouvi algumas delas dizerem que querem que elas usem a cocarda para depois fazê-las partir para as fronteiras, porque não há homens suficientes para defendê-las (...)". O relatório do mesmo agente Latour-Lamontagne, de 22 de setembro, continua com as mesmas preocupações: "a cocarda segue dividindo as mulheres, e parece que o decreto da Convenção Nacional não produziu todo o efeito prometido. Os mal-intencionados

\footnotetext{
${ }^{369}$ Rapport 13 septembre, 1793 - L'an 2ème. - Archives Nationales, Paris.

${ }^{370} 2$ documentos, 2 relatórios do mesmo agente, datas diferentes: Rapport de LatourLamontagne [ F7 3688 3] IN Paris pendant la Terreur - Rapports des Agents Secrets du Ministre de L'Intérieur - publicados por CARON, Pierre (autor da Introdução) - Tome Premier, 27 Août 1793 25 Décembre 1793, Paris , Librairie Alphonse Picard et fils, 1910,pp. 154-5 e 165.
} 
(...) adulam o amor-próprio das mulheres tentando persuadi-las que têm tantos direitos como os homens ao governo de seu país (....) num Estado em que a lei consagra a igualdade, as mulheres podem aspirar a todos os empregos civis e militares, e que as coisas iriam melhor se os negócios fossem conduzidos por boas republicanas (...) .Tal era o discurso de um muscadin (janota contra-revolucionário) disfarçado de sans-culotte (...) isso mostra que os maldosos usam de todas as manobras para semear a discórdia entre nós." Muitos parisienses, homens e mulheres, aceitaram a contra-gosto o decreto da obrigatoriedade da cocarda feminina, pois temiam que a Convenção em seguida decretasse também o porte do barrete frígio sobre cabelos curtos para as mulheres, o armamento, o voto feminino nas assembléias, e até, porque não, a renovação dos casamentos celebrados no antigo Regime. Os boatos mais estapafúrdios corriam em Paris ${ }^{371}$. As mulheres do mercado achavam que depois de usar a cocarda teriam que marchar para a fronteira; e o agente de polícia Latour receava a exigência feminina dos direitos políticos e cargos no governo; estava convencido de uma conspiração dos contra-revolucionários através das agitações políticas femininas. Mais uma vez, aparece o fantasma das mulheres influenciadas por maus elementos: elas não tinham independência de julgamento, eram pretensiosas, tinham aspirações políticas acima de sua capacidade. O caos resultante dessa balbúrdia só aproveitaria aos traidores. Depreende-se que era imprescindível manter o status quo feminino estavam em jogo a ordem social e política.

É evidente que o significado da "guerra das cocardas" ultrapassa o nível "jocoso" de brigas de bairro entre mulheres, nas quais os homens não interferiam. A "guerra" estava ligada à situação anômala das cidadãs sem cidadania. Para Albert Soboul, aqueles confrontos se situam no coração das lutas revolucionárias que envolveram a sans-culotterie. Dominique Godineau considera o decreto de 21 de setembro "uma vitória das cidadãs patriotas e uma vitória do movimento popular" (grifo meu), e a "ação vigorosa da sans-culotterie transformou uma reivindicação feminina numa reivindicação do movimento popular como um todo", não apenas da militância feminina ${ }^{372}$. Para a historiadora, naquele ambiente revolucionário do verão de 1793, obrigar as mulheres a usar a cocarda tricolor era reconhecer-lhes uma

\footnotetext{
${ }^{371}$ GODINEAU, Dominique, Citoyennes Tricoteuses - Les femmes du peuple à Paris pendant la Révolution Française, Paris, Editions Alinea, Perrin, 2004 , p. 170.

${ }^{372}$ GODINEAU, Dominique, Citoyennes Tricoteuses - Les femmes du peuple à Paris pendant la
} Révolution Française, Paris, Editions Alinea, Perrin, 2004 , p. 166. 
existência política, e talvez abrir caminho para o reconhecimento da igualdade política entre os sexos. A Convenção, entretanto, não pensava em dar mais nenhum passo nessa direção ${ }^{373}$. Na verdade, quando o decreto foi aprovado, já havia uma reação das autoridades contra as reivindicações das militantes turbulentas. Os membros da Sociedade das Republicanas Revolucionárias vinham sofrendo ataques de jornalistas e deputados, e estavam na defensiva. Por esta razão, não foram elas as protagonistas principais do conflito, iniciado pelas ativistas das Seções. Apesar de tantas Seções e clubes políticos, inclusive o dos Jacobinos, terem endossado a petição da cocarda, a Convenção só resolveu decretar o seu uso obrigatório para as mulheres depois que vinte e um agentes de polícia parisienses pediram providências contra a agitação urbana e "a profanação das cores nacionais sobre as vestes" das pessoas que as portavam. Portanto, a interpretação de Godineau não me satisfaz inteiramente: parece-me que a razão do decreto não foi distinguir as mulheres com o símbolo da cidadania, mas sim pacificar as ruas de Paris e restabelecer a ordem pública. Os tumultos podiam se alastrar, transformando-se num conflito de maiores proporções, desestabilizando o governo da Convenção. O momento era delicado, o governo tentava impor sua autoridade central perante a sans-culotterie adepta da descentralização secionaria do poder. Se a Convenção tivesse tido a intenção de decretar a cocarda feminina, porque não o fez quando recebeu a petição assinada pelas Seções e sociedades políticas? Tenho a impressão de que os deputados concederam o decreto "como um mal menor", assim como alguém que entrega os anéis para não perder os dedos. A "vitória" das militantes foi efêmera e superficial: poder desfilar nas ruas usando a cocarda - "os anéis". Mas os "dedos" eram os direitos políticos , que eles não tencionavam estender ao sexo feminino, como ficou claro no mês seguinte com o decreto de 30 de outubro de 1793, o qual suprimiu todas as associações políticas femininas na França. Se é que se pode falar em vitória nesse caso, ela cabe à Convenção, que agradou àquelas que queriam usar o símbolo da cidadania, pacificou os conflitos de rua, impediu a profanação das cores nacionais, mas em seguida negou às mulheres os direitos de cidade representados pela cocarda. Sem os direitos cívicos, o símbolo ficou esvaziado de sentido para as mulheres - elas continuaram a ser cidadãs sem cidadania. E as inimigas das militantes, obrigadas ao uso da cocarda, viram ali uma oportunidade para destruir politicamente as adversárias.

\footnotetext{
${ }^{373}$ GODINEAU, Dominique, Citoyennes Tricoteuses - Les femmes du peuple à Paris pendant la
} Révolution Française, Paris, Editions Alinea, Perrin, 2004 , pp. 164-169. 


\section{$\underline{1.17-O s \text { ataques às militantes }}$}

A hostilidade crescente tanto dos Montanheses como das outras mulheres acabou derrotando a Sociedade das Republicanas Revolucionárias no mês de outubro de 1793. As militantes não conseguiam superar a oposição das parisienses. As mulheres do mercado estavam fartas do tabelamento de preços, taxações forçadas, busca e apreensão de mercadorias açambarcadas, das quais eram alvos freqüentes. Elas consideravam as clubistas uma ameaça direta à sua sobrevivência. Olwen Hufton aponta o fato de que os administradores das Seções, em nome da guerra aos especuladores, preferiam atacar as donas de barracas de alimentos em vez dos grandes atacadistas de trigo. A localização do clube das Republicanas na igreja de Saint Eustache, vizinha ao mercado, gerava grande indignação, pois tornava as comerciantes mais vulneráveis à "bisbilhotice" das ativistas e possíveis denúncias de abusos ${ }^{374}$. Mas Claire Lacombe, acompanhada de uma deputação, continuava sua vigilância: em fim de setembro, pediu que a Comuna procedesse às visitas domiciliares para aplicar o preço "máximo" votado na véspera e impedisse as mercadorias de sair de Paris. As comerciantes não eram as únicas a se oporem às Republicanas Revolucionárias: as antigas criadas da aristocracia se opunham às punições severas para os antigos patrões, as religiosas continuavam leais ao clero refratário e as burguesas se opunham à participação política feminina, concordando com os homens que a maternidade cívica era a melhor maneira de mostrar seu patriotismo - todos esses grupos eram contrários às medidas terroristas defendidas pelas militantes ${ }^{375}$.

Os deputados Montanheses começaram a ver as Republicanas como agitadoras perigosas que atrapalhavam o governo convencional. As críticas e hostilidades às Republicanas começaram no outono. Em 16 de setembro, no clube dos Jacobinos, Chabot e Bazire, excluídos do Comité de Sûreté Génerale devido à pressão da Sociedade e sua presidente, passaram ao ataque. No início, preferiram deixar de lado as razões políticas para ironizar os supostos defeitos da mulher, como a frivolidade

\footnotetext{
${ }^{374}$ HUFTON, Olwen H., Women and the Limits of Citizenship in the French Revolution, Toronto, Buffalo, London, University of Toronto Press, 1992, p. 36.

${ }^{375}$ LEVY, Darline G., APPLEWHITE, Harriet B., JOHNSON, Mary D. - Women in Revolutionary

Paris - 1789-1795 - . Selected documents translated with notes and commentary by the authors Urbana e Chicago, University of Illinois Press, 1980, pp. 147-148.
} 
- uma forma de diminuir a estatura política da oponente. Depois acusaram Claire Lacombe, presidente das Republicanas, de insultar Robespierre, chamando-o de Monsieur, tratamento reservado aos nobres e agora considerado ofensivo, e de alojar em sua casa o contra-revolucionário (Enragé) Leclerc ${ }^{376}$. Ademais, ela teria insuflado as revoltas do açúcar em fevereiro e do sabão em junho. Taschereau a acusou de "se meter" em tudo, e querer destituir todas as autoridades constituídas.. N... disse que "a mulher denunciada perante nós é muito perigosa porque é muito eloqüente (grifo meu) (...) ela faz ataques fulminantes contra os Jacobinos e a Convenção". As mulheres presentes na sessão gritaram das galerias: " Abaixo a nova Corday , vá embora, infeliz, ou nós vamos te estraçalhar", ao que Lacombe respondeu que ia mostrar à primeira que ousasse fazê-lo "o que pode uma mulher livre". As críticas às Republicanas Revolucionárias já visavam indiretamente a participação política feminina, a que se atribuiu toda a turbulência em Paris. A proposta de pedir ao Comitê de Segurança Pública que mandasse prender todas "as mulheres suspeitas" foi aprovada por unanimidade. Lacombe foi detida por uma noite, mas libertada no dia seguinte pois em sua casa os agentes do Comitê só haviam encontrado papéis patrióticos.

A Feuille du Salut Public, de 24 de setembro, escreveu: "Vejam a mulher Lacombe, que se tornou uma bacante contra-revolucionária, amante dos homens e do vinho, testemunho da fraternidade íntima que reinava entre ela, Jacques Roux, Leclerc e companhia... !”377. Era a mesma linguagem difamatória que o jornal realista Petit Gautier usava para falar de Théroigne de Méricourt. A acusação não era política, e sim pessoal e moral . No dia 6 de outubro, A Sociedade dos homens de 10 de agosto acusou as Republicanas Revolucionárias de falta de civismo e pediu a interdição dos clubes autônomos de mulheres. Jacques Roux, escreveu da prisão em defesa da Sociedade das Republicanas, apesar de ter sido renegado por elas anteriormente: "A sociedade das Mulheres Revolucionárias que tantos serviços prestou à Liberdade foi

\footnotetext{
376 Todas as acusações a Lacombe estão nos documentos: La société des Jacobins: recueil de documents pous l'histoire du Club des Jacobins de Paris, e Rapport fait par la Citoyenne Lacombe à la Société des républicaines révolutionnaires (sic) de ce qui s'est passé le 16 septembre à la Société des Jacobins concernant celle des Républicaines révolutionaires séante à $S$. Eustache; et les dénonciations faites contre la Citoyenne Lacombe personnellement IN LEVY, Darline G., APPLEWHITE, Harriet B., JOHNSON, Mary D. - Women in Revolutionary Paris - 1789-1795 - . Selected documents translated with notes and commentary by the authors - Urbana e Chicago, University of Illinois Press, 1980, pp. 182-196.

${ }^{377}$ ROSA, Annette, Citoyennes, Paris, Messidor, 1988 . p. 214.
} 
denunciada no seio dos Jacobinos por homens que recorreram mil vezes à sua coragem e à sua virtude" e se indigna que " as republicanas mais fervorosas sejam tratadas como intrigantes". Mas essa defesa de Roux mais comprometia que ajudava, tornando as Republicanas suspeitas. No dia 7, Claire Lacombe tomou a palavra diante da Assembléia:

Esses intrigantes, caluniadores, não encontrando crimes contra nós, ousaram nos comparar às Médicis, à Rainha Elizabeth da Inglaterra, a uma Antonieta, a uma Charlotte Corday ! Mas será que nós somos responsáveis por algum crime ? Corday pertencia à nossa Sociedade ? Ah! Nós somos mais generosas que os homens. Nosso sexo só produziu um monstro, ao passo que há quatro anos nós somos traídas, assassinadas por monstros sem conta produzidos pelo sexo masculino. Nossos direitos são os do povo, e se formos oprimidas, saberemos resistir à opressão ${ }^{378}$.

Claire Lacombe era de fato eloqüente, e sabia se defender corajosamente. Tinha algum conhecimento de História e estava bem informada, inclusive utilizando um dos artigos da Declaração dos Direitos do Homem de do Cidadão em seu favor: o direito de resistência à opressão. Seria uma adversária política temível, se a luta fosse verbal. As Republicanas Revolucionárias usavam elas próprias o barrete vermelho da liberdade em suas reuniões, mas nunca tentaram impô-lo às outras mulheres. Não obstante, as vendedoras do mercado, que as detestavam, as acusaram precisamente desse delito. O barrete era prerrogativa masculina, principalmente da polícia - mas as revolucionárias militantes gostavam de usá-lo em sinal de seu engajamento ativo na Revolução. A simbologia do barrete era significativa: na antigüidade romana, era usado pelos escravos libertos. As militantes, através de suas práticas revolucionárias de cidadania, conseguiam " libertar-se" do estado de sujeição em que viviam antes. O barrete era o signo da recém-conquistada liberdade, daí o orgulho com que o portavam. Talvez por essa razão, homens e mulheres conservadores considerassem o uso do adereço pelas mulheres subversivo da "ordem natural das coisas". No dia 28 de outubro de 1793, a Sociedade das Republicanas foi convidada para a inauguração dos bustos de Marat e Lepeletier pela Seção da Réunion. Elas compareceram com seus barretes vermelhos, uma bandeira e quatro piques. Foram abertamente hostilizadas pelas mulheres do mercado que gritavam insultos das galerias: "abaixo o barrete vermelho, abaixo as jacobinas e a cocarda! São essas vigaristas que fizeram a infelicidade da França!" . Nesse momento, a multidão de mulheres enfurecidas desceu

378 ROSA, Annette, Citoyennes, Paris, Messidor, 1988 , p. 214 
das galerias e invadiu a sala, surrando e arrastando as militantes; muitas ficaram feridas, algumas inconscientes. Soldados acalmaram a situação, liberando as agressoras e insistindo em retirar as Republicanas do recinto "para sua segurança". Elas queriam que se lavrasse um auto dos incidentes na sua presença, mas isso só foi feito mais tarde, quando elas concordaram em deixar a sala por uma passagem secreta, sob ameaça dos gritos:" Viva a República! Abaixo as revolucionárias!". As autoridades da Seção não eram simpáticas à Sociedade das Republicanas e viram ali uma oportunidade de culpar as Republicanas pela violência. Não há nenhum relato das próprias vítimas sobre a agressão. $\mathrm{O}$ auto dos incidentes ( procès-verbal) foi publicado no jornal de Prudhomme $^{379}$ - tal relato deixa claro que as mulheres do mercado foram as agressoras e as Republicanas as vítimas. No dia seguinte, porém, uma delegação de comerciantes do mercado apresentou queixa na Convenção, pedindo que ela não aderisse ao barrete vermelho para as mulheres e que abolisse a Sociedade das Republicanas Revolucionárias.

Na sessão do dia 29 de outubro na Convenção, o deputado Fabre d"Églantine se fez o porta-voz das preocupações masculinas acerca da escalada de exigências da militância feminina ${ }^{380}$ : "já houve problemas com a cocarda; vocês decretaram que as mulheres a portariam; hoje pedem o barrete vermelho: mas as coisas não vão parar por aí; em breve vão exigir um cinturão com pistolas, de maneira que isso coincidirá com a manobra dos ajuntamentos do pão, e vocês verão filas de mulheres ir comprar pão como quem marcha para as trincheiras. Nossos inimigos atacam a paixão mais forte das mulheres, que é a das roupas (grifo meu); e com esse pretexto, colocaríamos em suas mãos armas das quais não sabem se servir, mas que os maus elementos usariam muito bem. E esse não é o único germe da divisão desse sexo: ele forma coalizões de mulheres sob o nome de instituições revolucionárias, fraternas etc. Observei que tais sociedades não são compostas de mães de família, moças de família, irmãs ocupadas

\footnotetext{
${ }^{379}$ PRUDHOMME, Révolutions de Paris, vol. XVII, no. 215 ("du tridi 23 Brumaire au decadi 30, an deuxième de la République française, une et indivisible"), pp. 207-10 IN LEVY, Darline G., APPLEWHITE, Harriet B., JOHNSON, Mary D. - Women in Revolutionary Paris - 1789-1795 - . Selected documents translated with notes and commentary by the authors - Urbana e Chicago, University of Illinois Press, 1980, pp. 209-212.

${ }^{380}$ As citações deste parágrafo estão no documento: ÉGLANTINE, Fabre, Archives Parlementaires de 1787 a 1860 Recueil complet des débats législatifs \& politiques des Chambres françaises, première série (1787 à 1799) tome LXXVIII, Paris, Librairie Administrative Paul Dupont, 1911. IN LUCAS, Colin, Editor-in-Chief The French Revolution Research Collection, University of Chicago, 1992 , The New York Public Library, microficha 9.4/229.
} 
com irmãos mais novos, mas sim espécies de aventureiras, cavaleiras errantes, jovens emancipadas, granadeiras-fêmeas ( aplausos) Peço duas coisas urgentes, pois as mulheres de barrete vermelho já estão nas ruas (grifo meu): peço que decretem que nenhum indivíduo, sob qualquer pretexto, e sob pena de ser perseguido como perturbador do repouso público, poderá forçar outro cidadão a se vestir de maneira diferente de sua vontade. Em seguida, peço que o Comitê de Segurança Geral faça um relatório sobre as sociedades de mulheres" Tais propostas são vivamente aplaudidas. As peticionárias gritam: "Abaixo os barretes vermelhos! Abaixo as sociedades de mulheres! Viva a Convenção! etc" "Uma cidadã pediu a palavra: ela passou à tribuna e disse: eu peço a abolição de todas as sociedades de mulheres que se reúnem em clubes, porque foi uma mulher que causou a infelicidade da França - Esta petição foi enviada ao Comitê de Segurança Geral". Basire acrescentou que houve protestos contra os eventos da igreja de Saint-Eustache (local da agressão às Republicanas), e o deputado Amar apresentaria um relatório sobre a questão na próxima sessão.

Muitos homens viam na apropriação feminina dos símbolos republicanos uma ameaça à sua supremacia: primeiro quiseram a cocarda, agora cobiçavam o barrete vermelho! Fabre d"Églantine expressou todas as angústias masculinas acumuladas naqueles meses do verão de 1793. A ambição das mulheres não tinha limites, elas queriam ter os mesmos direitos e a mesma liberdade que os homens! As mulheres estavam avançando perigosamente no terreno da igualdade, e da indiferenciação dos sexos! ${ }^{381}$. Fabre d’Églantine acenou com o fantasma das mulheres agressivas, armadas e desenfreadas: elas eram perigosas, mas também ridículas, porque não sabiam manejar as armas. O pesadelo das mulheres manipuladas por maus elementos não podia faltar no discurso. Outra ameaça eram aquelas que provocavam intranqüilidade pública nas filas do pão. A redução do barrete frígio a uma questão de vestuário e moda serve para desqualificar as mulheres que o usam como membros do corpo político, e colocá-las no terreno da vaidade e frivolidade. Ora, nessa época, a roupa não era neutra, pelo contrário, era uma afirmação pública de convicções políticas. Como não poderia deixar de ser, o barrete frígio era entendido dessa maneira por todos: se fosse só questão de moda, não causaria tanta celeuma. Na cabeça das mulheres, ele tinha um significado perturbador de desafio à ordem social, à ordem da

\footnotetext{
${ }^{381}$ ROSA p. 170.
} 
natureza, à hierarquia dos sexos. Interessante notar que na iconografia, ele é atributo da deusa da Liberdade, e isso não incomoda ninguém, pois a deusa está acima das turbulências políticas. Já quando o barrete vai para as cabeças de mulheres reais nas ruas de Paris, passa a ser subversivo. Lembra a todos que o sexo feminino também quer "se libertar da escravidão" e conquistar seus direitos. Églantine considera que as revolucionárias não são respeitáveis, porque não são mães ou moças dedicadas à família - elas são uma aberração, versões femininas de guerreiros masculinos. O deputado associou o ativismo político ao desregramento moral. Na Revolução, as que não eram esposas e mães estavam à margem do padrão moral da República da Virtude. Embora muitas militantes fossem mães, sua atividade política as colocava em outra esfera - de tal modo que sempre pairava sobre elas a suspeita de pouca virtude. O deputado adotou um tom alarmista: as mulheres "de barrete vermelho" já estão nas ruas" - cuidado, o perigo anda à solta! A questão era urgente! Elas ameaçavam a definição dos papéis dos gêneros e portanto a boa ordem social .

\subsection{8 - A supressão da Sociedade das Republicanas Revolucionárias}

No dia seguinte ao pronunciamento de Fabre d"Églantine, 30 de outubro de 1793, Jean-Batiste André Amar, relator do Comité de Segurança Geral fez um discurso memorável na Convenção sobre os direitos políticos femininos ${ }^{382}$. Começou estabelecendo uma versão fantasiosa dos acontecimentos da ante-véspera na antiga igreja de Saint-Eustache: as Republicanas Revolucionárias teriam querido impor o barrete vermelho e as calças compridas às outras mulheres, infringindo a liberdade alheia da escolha de vestuário, dando origem ao confronto. Amar relatou que o mesmo aconteceu no mercado dos Inocentes: mulheres se dizendo jacobinas, de uma "sociedade supostamente revolucionária", quiseram obrigar as outras a adotar o barrete e as calças compridas. Formou-se um ajuntamento de seis mil mulheres e as cidadãs (comerciantes) disseram que não cederiam aos caprichos de uma centena de mulheres ociosas e suspeitas. Esse movimento só podia ser atribuído a um complô dos inimigos da coisa pública. Amar tampouco hesitou em apontar uma possível conexão

\footnotetext{
${ }^{382}$ Todas as citações do documento de Amar nos próximos parágrafos estão em : Archives Parlementaires de 1787 a 1860 . Recueil complet des débats législatifs \& politiques des Chambres françaises, première série (1787 à 1799) tome LXXVIII, Paris, Librairie Administrative Paul Dupont, 1911. IN LUCAS, Colin, Editor-in-Chief The French Revolution Research Collection, University of Chicago, 1992 , The New York Public Library, microficha 9.4/230.
} 
política entre os Girondinos e as Republicanas Revolucionárias, que, ao contrário, eram próximas dos Enragées. A Seção dos Marchés (mercados) anunciou que acreditava que alguns mal-intencionados sob a máscara de um patriotismo exagerado incitavam um movimento secionario e uma espécie de contra-revolução em Paris. Esta Seção pede que seja proibido constranger qualquer pessoa na sua liberdade indumentária, e que as sociedades populares de mulheres sejam severamente proibidas, pelo menos durante a Revolução. Amar passou em seguida à questão fundamental do relatório, perguntando primeiro se as mulheres poderiam exercer direitos políticos e ter um papel ativo no governo, e segundo, se poderiam se reunir em Sociedades populares. Sua resposta a ambas as perguntas foi negativa. E assim, em vez de proceder a uma investigação dos distúrbios do barrete vermelho, e ordenar o fechamento específico da Sociedade das Republicanas Revolucionárias, caso este grupo de militantes fosse pronunciado culpado, Amar ordenou o fechamento de todos os clubes políticos femininos no país, sob qualquer denominação que fosse. $\quad$ E foi além, julgando que o sexo feminino como um todo era incapaz de exercer direitos políticos. O relatório de Jean-Batiste André Amar é o único texto teórico do legislativo sobre os direitos políticos das mulheres $^{383}$. As razões que o fundamentam são relevantes para a compreensão da repressão política das ativistas.

"Governar é reger a coisa pública por leis cuja confecção exige conhecimentos extensos (...) uma impassibilidade severa (...) dirigir e retificar a ação das autoridades constituídas" As mulheres em geral não têm essas qualidades. É necessário saber comparar deliberações e resistir à opressão: "as mulheres têm a força moral e física para exercer um e outro desses direitos? A opinião universal rejeita essa idéia (grifo meu)." Quanto às associações políticas, seu objetivo é "revelar as manobras dos inimigos da coisa pública, vigiar os cidadãos como indivíduos e os funcionários públicos (...) esclarecer-se por meio de discussões públicas e profundas sobre o defeito ou reforma das leis políticas. As mulheres podem exercer essas funções úteis e penosas? Não, porque elas seriam obrigadas a sacrificar cuidados mais importantes que a natureza lhes reservou; As funções privadas às quais a mulher está destinada pela natureza se relacionam à ordem geral da sociedade; tal ordem resulta da diferença existente entre 0 homem e a mulher (grifo meu). Cada sexo foi chamado a um gênero de ocupação que 
lhe é próprio, sua ação está circunscrita num círculo que ele não pode ultrapassar (...) o homem é forte, robusto, nascido com grande energia, audácia e coragem (...) só ele tem a inteligência e a capacidade para as meditações profundas e sérias que exigem um grande controle do espírito e longos estudos que a mulher não foi feita para seguir. Qual é o caráter da mulher? A moral e os bons costumes e a natureza determinam suas funções: começar a educação dos homens, preparar o espírito e o coração das crianças de acordo com as virtudes públicas, a mulher se destina naturalmente a fazer amar a virtude. Quando elas cumprirem todos esses deveres, terão bem merecido a pátria. ; devem elas tomar parte em discussões acaloradas incompatíveis com a doçura e a moderação que são o charme de seu sexo? Devemos dizer que essa questão está ligada à moral e aos bons costumes, porque sem moral, não há República. (grifo meu) A honestidade de uma mulher permite que ela se mostre em público, lute com os homens, e discuta (...) questões das quais depende a salvação da República? Em geral, as mulheres são pouco capazes de concepções elevadas (...) Vocês querem que na República francesa elas venham à tribuna (...) abandonando a sua reserva, fonte de todas as virtudes desse sexo (grifo meu), e os cuidados de suas famílias? Nós cremos que uma mulher não deve sair de sua família para se imiscuir nos negócios do governo. Há um outro aspecto que torna as associações políticas femininas perigosas: (...) a educação política dos homens está em sua aurora, os princípios ainda não estão desenvolvidos, nós balbuciamos o nome da liberdade (...) as mulheres são menos esclarecidas nos princípios. Sua presença nas sociedades populares daria um papel ativo no governo a pessoas mais expostas a erro e sedução (...) Desde o início da Revolução, as mulheres, mais escravas dos preconceitos nobiliárquicos e religiosos que os homens, têm estado constantemente nas mãos dos padres e inimigos do Estado, e [têm sido] as primeiras causadoras das turbulências que agitaram a República (grifo meu) (...) Acrescentemos que as mulheres são dispostas ( ...)a uma exaltação que seria funesta (grifo meu) nos assuntos públicos e os interesses do Estado seriam sacrificados a tudo o que as paixões podem produzir de desvios e desordem (...) Os senhores destruirão essas pretensas sociedades populares de mulheres que a aristocracia gostaria de estabelecer, para que elas enfrentem os homens, dividam-nos, forçando-os a tomar partido em suas querelas, criando problemas ". Uma única voz protestou: o deputado radical Charlier, futuro detrator de Robespierre, alegou que não conhecia nenhum 
princípio que justificasse subtrair das mulheres o direito de se reunir pacificamente,

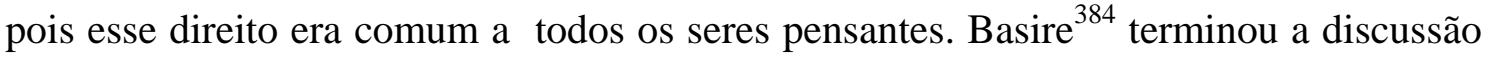
dizendo que "os inconvenientes das sociedades de mulheres eram demasiado reais" , além do que "os senhores se declararam governo revolucionário, e nesta qualidade, podem tomar quaisquer medidas exigidas para a segurança pública". Na sua opinião, a experiência recente tinha provado que essas sociedades perturbavam a tranqüilidade pública. E pediu que fossem proibidas, pelo menos durante a Revolução. .

Penso que se o alvo de André Amar e do Comitê de Segurança Pública fosse apenas a Sociedade das Republicanas Revolucionárias, ele poderia simplesmente ter decretado o fechamento daquela associação, atendendo ao pedido das comerciantes do mercado. Mas o alvo era muito mais abrangente, tratava-se da mulher politizada. A ação das Republicanas e outras ativistas há muito incomodava a maioria dos homens, e em particular, os deputados da Convenção. Elas se consideravam cidadãs e parte do Povo Soberano, embora sua agenda não fosse propriamente feminista: a sua única reivindicação de igualdade de direitos foi relativa ao porte de armas ${ }^{385}$. Suas práticas políticas tinham dado visibilidade à questão dos direitos cívicos das mulheres, forçando os líderes revolucionários a se pronunciarem a esse respeito. Uma decisão se impunha, num contexto desfavorável para elas. Os decretos de Brumário de 1793 tinham o objetivo de cercear a mulher politizada e não apenas membros de clubes políticos. Amar justificou suas decisões invocando as tradições culturais : " a opinião universal"; a "ordem geral da sociedade"; a natureza, que estabelece funções de acordo com a diferença entre os sexos e "não recebe nenhuma outra lei"; a moral e os bons costumes, que não permitem que a mulher atue na esfera pública; a fraqueza física e moral da mulher que não conseguiria "resistir à opressão"; supostas características femininas como a propensão à "exaltação funesta" nos assuntos públicos; a experiência revolucionária que identificava as agitações com a ação feminina; razões políticas como a falta de compreensão dos princípios revolucionários e a tendência de se deixar manipular pelos religiosos e outros inimigos do Estado, os

\footnotetext{
${ }^{384}$ Bazire, Chabot e Fabre d'Églantine foram os primeiros Convencionais a se voltarem contra as Republicanas Revolucionárias no outono de 1793. Eram Montanheses moderados, futuros Indulgentes dantonistas. Em setembro, Bazire e Chabot foram excluídos do Comitê de Segurança Geral por pressão das ativistas. Na primeira oportunidade, contra-atacaram violentamente IN GODINEAU, Dominique, Citoyennes Tricoteuses - Les femmes du peuple à Paris pendant la Révolution Française, Paris, Editions Alinea, Perrin, 2004 , p. 166 e 174.

${ }^{385}$ Conforme discurso de Pauline Léon citado nesta dissertação.
} 
quais agiam contra a Revolução estabelecendo clubes femininos.

$\mathrm{O}$ argumento dos deveres maternos serviu para reforçar a divisão dos papéis femininos e masculinos, que estão na base da moral: "sem moral não há República" ("point de moral, point de République"). A mãe que abandona seus filhos para se imiscuir na vida política esquecendo das "virtudes de seu sexo" - está prejudicando a própria República, a qual depende das qualidades morais de cada cidadão. Para o relator André Amar, a falta de moral na vida privada afeta o bem comum, a felicidade geral - pensamento típico da época, que apagava as fronteiras entre o privado e o público. O convencional se fez porta-voz de todas as angústias masculinas a respeito da mulher politizada, às vezes armada e violenta, que enfrenta os homens nos debates da Assembléia, apagando as diferenças dos papéis sexuais. Eles insistiam na necessidade da diferenciação entre homens e mulheres. A igualdade de direitos equivalia a uma "inversão dos papéis", levando ao caos social, porque era contra a moral. Isso seria a ruína da República.

Dominique Godineau considera que a misoginia se exprimiu abertamente na Assembléia naquele dia, mas não porque os Montanheses fossem mais "falocráticos" que os Girondinos, mas sim porque havia urgência em resolver a questão ${ }^{386}$. Os homens não protestaram contra o decreto, nem na Comuna, nem nas Seções, nem entre os sans-culottes. Eles não perceberam que o governo que decide arbitrariamente proibir clubes femininos podia fazer o mesmo com os masculinos. O jornal Révolutions de Paris de Prudhomme, observou que: " Não é mais permitido às mulheres se organizar em clubes; serão toleradas como espectadoras, silenciosas e modestas, nas sociedades patrióticas; na verdade, as mulheres não podem mais buscar notícias fora de suas casas; vão recebê-las das bocas de seus pais, filhos irmãos ou maridos"387. A Convenção não foi tão longe assim, mas o editor insiste em que as mulheres só deveriam receber noticias através dos homens da família - essa idéia de Prudomme já foi citada na presente dissertação (diálogo pelo jornal com as cidadãs dos clubes de Dijon e Lyon). Já Olwen Hufton atribui o fechamento dos clubes políticos femininos pelo Comitê de Salvação Pública à necessidade de reduzir as tensões nos

\footnotetext{
${ }^{386}$ GODINEAU, Dominique, Citoyennes Tricoteuses - Les femmes du peuple à Paris pendant la Révolution Française, Paris, Editions Alinea, Perrin, 2004, p. 176.

${ }^{387}$ PRUDOMME, Révolutions de Paris, no. XVII, IN GEORGE, Margaret, The "World Historical

Defeat" of the Républicaines Révolutionnaires, Science \& Society, 40.4 (winter 1976-1977), p. 436.
} 
mercados e à ameaça à ordem pública geradas pelos distúrbios [entre mulheres] ${ }^{388}$, não levando em consideração as razões políticas , sociais e de mentalidade discutidas neste texto. Penso que não se pode reduzir a questão ao viés econômico, sob pena de deixar escapar aspectos importantes para a compreensão daquele momento revolucionário crucial para a definição dos direitos políticos femininos.

O único protesto partiu das próprias Republicanas Revolucionárias, que pediram a palavra na Convenção e disseram: " A Sociedade das Republicanas Revolucionárias, composta em grande parte de mães de família, não existe mais. Uma lei motivada por um relatório falso proíbe que nos reunamos ..." Nesse ponto a oradora foi interrompida por gritos de "ordem do dia!" , aplausos, vaias e gargalhadas, e as ativistas tiveram que se retirar " precipitadamente" ${ }^{\text {"389 }}$. As milhares de mulheres dos clubes femininos no resto da França ficaram em silêncio e encerraram suas atividades, talvez porque não tivessem força para lutar contra a decisão da Convenção, e nem massa crítica de seguidoras dispostas a um protesto em grande escala. Ou por outro motivo mais palpável: a Lei do Máximo e a fiscalização de seu cumprimento agradou sobremaneira as consumidoras, principalmente as esposas e mães de família sansculotte. Elas conheciam todos os regulamentos e as leis econômicas e utilizavam esse saber prático na hora de fazer compras, calculando o preço dos gêneros com referência ao Máximo. Há um caso de um açougueiro que exigiu mais dinheiro pela mercadoria, e a consumidora respondeu que ainda que o valor não o agradasse, " é o que a lei estipula" $^{390}$. As sans-culottes achavam que o tabelamento de preços e outras medidas foram adotadas para proteger especificamente seus interesses ${ }^{391}$. Melhor ainda, as leis vieram acompanhadas da guilhotina para os infratores. Ou seja, os jacobinos adotaram o programa radical da sans-culotterie ao mesmo tempo que alijavam suas mais estridentes defensoras, as Republicanas Revolucionárias.

Apesar de não terem oficialmente reivindicado o direito ao voto para as mulheres, as Republicanas Revolucionárias tinham consciência de sua especificidade

\footnotetext{
${ }^{388}$ HUFTON, Olwen H., Women and the Limits of Citizenship in the French Revolution, Toronto, Buffalo, London, University of Toronto Press, 1992, p.38.

389 GEORGE, Margaret, The "World Historical Defeat" of the Républicaines Révolutionnaires,

Science \& Society, 40.4 (winter 1976-1977), pp. 436- 437.

${ }^{390}$ HUFTON, Olwen H., Women and the Limits of Citizenship in the French Revolution, Toronto, Buffalo, London, University of Toronto Press, 1992, p. 39.

${ }^{391}$ HUFTON, Olwen H., Women and the Limits of Citizenship in the French Revolution, Toronto, Buffalo, London, University of Toronto Press, 1992, p. 38-39.
} 
feminina no movimento revolucionário ${ }^{392}$ Elas aplaudiram as leis civis que protegiam as esposas das dilapidações de patrimônio do marido, e a Sra. Dubreuil, secretária do clube, respondeu aos que criticavam a associação que esses homens eram apegados ao "despotismo marital" e republicanos indignos, que queriam manter a mulher num estado de aviltamento. Há , portanto, sinais de que elas se preocupavam em melhorar a condição feminina na sociedade - o tema teria sido tratado nas sessões do clube, mas os registros das reuniões desapareceram, com exceção de um testemunho "relativamente digno de fé" de Pierre Roussel, que teria assistido a uma das sessões com seu convidado inglês, Lord Bedford. Restam as intervenções públicas das Republicanas, de onde as questões feministas estão ausentes.

Com o fechamento dos clubes, os membros da Sociedade das Republicanas Revolucionárias se dispersaram. Pauline Léon foi detida junto com o marido, o Enragé Théophile Leclerc, em abril de 1794, e prestou uma declaração da prisão do Luxemburgo professando patriotismo, negando qualquer crime ou afiliação política questionável. O que me pareceu significativo, apesar das circunstâncias do depoimento, foi a afirmação da doutrina da domesticidade e do papel de esposa por parte de Pauline Léon ${ }^{393}$ : " Casei-me com um patriota pobre e perseguido e quando ele foi chamado para defender o país, aceitei a separação não só com resignação mas com completa devoção". Como vemos na iconografia republicana , as esposas sempre são abnegadas e apóiam o marido que parte para a fronteira. " Dediquei-me aos cuidados do lar e dei um exemplo de amor conjugal e virtudes domésticas que são o fundamento do amor à Pátria (...) (grifo meu)" - na sociedade republicana, a mulher prova seu patriotismo exercendo virtudes domésticas, misturando a esfera privada com a pública. A militante Pauline Léon viajou para La Fère ao encontro do marido para se despedir dele antes da partida para a guerra, devido ao "sentimento irresistível para uma jovem casada de abraçar o marido pela última vez". Ela concorda que o principal na vida da mulher é seu papel na família, e que isso é amar a Pátria, como queriam os líderes republicanos. Por outro lado, afirma que serviu à Pátria - politicamente, como

\footnotetext{
392 GODINEAU, Dominique, Citoyennes Tricoteuses - Les femmes du peuple à Paris pendant la Révolution Française, Paris, Editions Alinea, Perrin, 2004 , as informações do parágrafo estão nas pp. 176-177.

393 LEÓN, Anne Pauline, femme Leclerc, fonte: Archives Nationales, F7 4774 9, dossier Leclerc IN LEVY, Darline G., APPLEWHITE, Harriet B., JOHNSON, Mary D. - Women in Revolutionary Paris - 1789-1795 - . Selected documents translated with notes and commentary by the authors Urbana e Chicago, University of Illinois Press, 1980, pp. 158-160.
} 
membro da Sociedade das Republicanas Revolucionárias - com desinteresse e fervor. Para as militantes, não havia incompatibilidade entre a vida familiar privada e a atividade política. Foi libertada da prisão pouco tempo depois. Claire Lacombe foi detida na mesma época que Pauline, acusada de hebertismo, ficando presa um ano e meio. Nunca renegou o governo do Ano II nem Robespierre depois de sua queda, e assinava-se "Lacombe, mulher livre". Mas a prisão quebrou seu espírito, na opinião de suas amigas - apesar da insistência das antigas companheiras, ela abandonou definitivamente a política e deixou Paris. Voltou à vida de atriz, aos seus amores e à obscuridade ${ }^{394}$.

\subsection{9 - As tricoteiras}

Os clubes políticos exclusivamente femininos desapareceram, mas muitas mulheres continuaram freqüentando sociedades jacobinas masculinas ou mistas, teoricamente sem direito a voz nem voto, até 1795, quando sua presença nas galerias foi proibida. Na prática, como atestam os relatórios de polícia dos meses do Terror, elas continuaram participando ativamente, inclusive como oradoras das sociedades fraternais das Seções, não raro assumindo posturas ultra-radicais: "Seção do Panthéon: uma deputação da sociedade fraternal desta seção se apresenta: uma oradora tem a palavra; alguns cidadãos protestam, dizendo que uma mulher não tem o direito de falar nem de deliberar nas assembléias de acordo com a lei, mas enfim concordam em que ela fale" ${ }^{\text {395 }}$. O Relatório do observador de polícia Rolin aponta igualmente a atuação feminina: "Os cidadãos e cidadãs que compõem a sociedade fraternal desta Seção [do Panthéon] fazem saber à Assembléia Nacional, por uma deputação dos dois sexos, de uma decisão que tomaram de expulsar de todos os cargos no governo os padres casados ou não, mesmo sem batina, todos os procuradores, nobres, advogados, e os togados [pertencentes à nobreza togada]. Uma cidadã era a oradora da deputação; ela reforçou a decisão com um discurso mais que revolucionário, pretendendo que era necessário excluí-los de todas as assembléias". E em 30 Frimário, uma deputação de "grande

\footnotetext{
${ }^{394}$ GEORGE, Margaret, The "World Historical Defeat" of the Républicaines Révolutionnaires, Science \& Society, 40.4 (winter 1976-1977), p. 437.

3953 documentos: Deuxième rapport de MERCIER ( F7 3688 3) e ROLIN , (21 dezembro 1793) [F7 3688 3] e citação do Moniteur, $1^{\text {er }}$ Nivoso, IN Paris pendant la Terreur - Rapports des Agents Secrets du Ministre de L'Intérieur - publicados por CARON, Pierre (autor da Introdução) - Tome Premier, 27 Août 1793 - 25 Décembre 1793, Paris , Librairie Alphonse Picard et fils, 1910, pp. 315, 323.
} 
número de cidadãs" se apresentou na tribuna da Convenção pedindo a liberdade de seus parentes encarcerados, pelos quais atestavam inocência. Robespierre manifestou reservas sobre os móveis dos autores da petição, onde ele via a mão da aristocracia. Não era a primeira vez que Robespierre considerava as mulheres instrumentos de contra-revolucionários. Enquanto as mulheres tiveram o uso da palavra, foram consideradas uma força no movimento popular - muitos homens temiam o discurso feminino e seu poder de arrastar a multidão.

As mulheres tricotavam ou costuravam nas tribunas, muitas vezes para os soldados do exército, enquanto ouviam os discursos dos deputados e membros dos clubes masculinos. As tricoteiras eram as "habituées des tribunes", a maioria das quais eram costureiras e lavadeiras, criadas domésticas, comerciantes, algumas professoras, parteiras e até donas de prostíbulos. As militantes não recusavam as funções sociais femininas, especialmente a maternidade, mas não julgavam que elas excluíssem a mulher da vida pública. Porém, a realidade das obrigações maternas eram um obstáculo à militância assídua. Assim, as ativistas em geral eram mulheres na faixa dos 30 a 40 anos sem filhos pequenos ou então bastante jovens, ainda sem filhos. Em geral, vinham se instruir e controlar os debates junto com as vizinhas e amigas, sem os maridos. Alguns deles aprovavam essa atividade. Um patriota demonstrava orgulho do interesse de sua mulher pela coisa pública: " Era sempre necessário haver bons patriotas no Tribunal para se impor aos juízes". A presença nas tribunas era um ato de cidadania, como dizia a Mère Duchesne: "(...) é necessário observar, denunciar tudo o que é contrário à Constituição e aos direitos da mulher". Não obstante, as mães não estão ausentes da vida política e das assembléias: não era raro encontrar mulheres com seus bebês nos braços, e outros filhos mais velhos em volta. Nesses casos, os deputados e outros espectadores se queixavam dos gritos das crianças que atrapalhavam a sessão. Outros maridos deploravam as esposas militantes, como no caso da mãe que não perdia as sessões dos Jacobinos e um dia, ao voltar para casa , encontrou seu filho queimado. "Boa jacobina, mãe malvada". Esse incidente foi publicado no jornal Le Sans-culotte observateur, que exprimia a moral conservadora da exaltação das virtudes domésticas, e dos papéis de gênero bem definidos, aliás, compartilhada com a da burguesia ${ }^{396}$. As mulheres eram maioria entre os espectadores

\footnotetext{
${ }^{396}$ MARAND-FOUQUET, Catherine, La femme au temps de La Révolution - Paris, Éditions Stock/Laurence Pernoud, 1989, pp. 268-9.
} 
que iam assistir às deliberações do Conselho Geral da Comuna, apesar de não serem bem acolhidas pelo procurador Chaumette, que disse a respeito de uma delas: " a cidadã seria talvez mais útil em sua casa do que nas tribunas do Conselho Geral" ${ }^{\text {"397 }}$. Outro comentou que as cidadãs ocupavam o lugar dos cidadãos que poderiam contribuir com seu espírito para a coisa pública mais do que elas.

Essas eram as tricoteiras que no dizer dos observadores de polícia do Ano III se tornaram "bebedoras de sangue", "mulheres ferozes que assistem todos os dias às execuções", e "fúrias da guilhotina". Algumas mulheres empregavam uma linguagem violenta, dizendo que "tudo iria melhor se houvesse guilhotinas permanentes em todas as encruzilhadas de Paris" . Mas Dominique Godineau pensa que com o país em guerra externa, às voltas com a guerra civil, o povo acreditava estar rodeado de inimigos que queriam massacrá-lo ${ }^{398}$. As mulheres acusadas de se alegrar com as execuções pediam a morte dos traidores, dos conspiradores, dos inimigos dos direitos do povo, daqueles que tramavam o fim da Revolução, que para elas representava a esperança de uma vida melhor. A cidadã Boudray expressou esse sentimento em carta aos Jacobinos no ano II: " Se vocês fraquejarem um instante, a coisa pública se perderá. Os patriotas serão degolados e esses homens, por quem tentam nos inspirar compaixão, não se cansarão de derramar o sangue mais puro da Revolução. Só haverá felicidade para todos quando nossos inimigos forem arrasados". Assim, o desejo de defender a Revolução, o instinto de preservação e o medo da traição fazem as mulheres pedirem mais execuções. Há um estudo de D. Arasse que liga a guilhotina à noção de soberania popular, alegando que o seu uso político transforma a multidão em povo soberano. Como as mulheres estavam legalmente excluídas da soberania, pois não votavam nem portavam armas, assistir às execuções lhes daria um sentimento de fazer parte do corpo político e da cidadania. Era também uma maneira de certificar-se de que se fazia justiça contra os inimigos da nação.

Os líderes revolucionários e a sociedade em geral tiveram dificuldade de aceitar a mulher e a revolucionária num só indivíduo. A mulher tinha que ser doce e tímida,

\footnotetext{
${ }^{397}$ GODINEAU, Dominique, Citoyennes Tricoteuses - Les femmes du peuple à Paris pendant la Révolution Française, Paris, Editions Alinea, Perrin, 2004 , p. 211.

398 As citações deste parágrafo estão em GODINEAU, Dominique, Citoyennes Tricoteuses - Les femmes du peuple à Paris pendant la Révolution Française, Paris, Editions Alinea, Perrin, 2004 , pp. 227-233.
} 
não podia ser desenvolta como as ativistas políticas. Era preciso atribuir características masculinas repulsivas àquela "mulher-homem" que queria "trocar de sexo". Apesar das evidências contrárias, foram chamadas de "feias de dar medo" , com os lábios e rostos enegrecidos de tanto gritarem. Chaumette fez um discurso virulento contra as mulheres que se apresentaram na Comuna usando barretes frígios em 27 Brumário de 1793, logo após a proibição dos clubes políticos femininos ${ }^{399}$ : " é horrível, é contrário a todas as leis da natureza uma mulher que quer se tornar homem. (...) a lei ordena que a moral seja respeitada e aqui eu a vejo desprezada" "Lembrem-se da esposa pretensiosa de um marido tolo , La Roland, que se achava apta a governar a República e que se precipitou na ruína" "lembrem-se da despudorada Olympe de Gouges, a primeira a estabelecer sociedades de mulheres, que abandonou os cuidados de seu lar para se imiscuir na República, e cuja cabeça caiu sob a faca vingadora das leis". Os exemplos de Madame Roland e Olympe de Gouges deixam entrever o destino das mulheres politizadas que "se esqueciam das virtudes de seu sexo". $\quad$ Além de sofrerem a pena de morte, as mulheres do povo "habituées des tribunes" se transformaram no imaginário popular em monstros ferozes, verdadeiras "fúrias da guilhotina". O tema será abordado novamente no capítulo da iconografia.

1.20 - As insurreições de Germinal e Prairial do Ano III (1 de abril e 20 a 23 de maio $\underline{\text { de 1795) }}$

O inverno de 1794-1795 foi excepcionalmente rigoroso. A colheita do outono de 1794 tinha sido desastrosa, provocando escassez de trigo, e a resposta do governo termidoriano à crise foi liberar a economia dos controles impostos durante o Terror. Em dezembro de 1794 as Leis do Máximo foram revogadas. O preço do pão voltou a ser um problema social, o que não ocorria desde 1791. George Rudé salienta que, apesar das parcas evidências, pode-se pensar que os salários dos operários parisienses tinham caído aos níveis catastróficos do início de $1789{ }^{400}$. Na primavera de 1795 - Ano III havia fome na capital, homens e mulheres desmaiavam de inanição nas ruas. A ração

${ }^{399}$ Discurso do Procurador da Comuna de Paris, Chaumette IN PRUDOMME , Révolutions de Paris, no. 216 - 49 de la Convention Nationale - du primidi, au nonodi, 9 frimaire, l'an deuxieme de la république française une \& indivisible - "Les Tu \& les Vous". IN LUCAS, Colin, Editor-in-Chief The French Revolution Research Collection, University of Chicago, 1992 , The New York Public Library, microficha no. 9.4/231.

${ }^{400}$ RUDE, George, The Crowd in the French Revolution, London, Oxford University Press - Oxford at the Clarendon Press., pp.143-145. 
diária de pão por pessoa caiu para $60 \mathrm{~g}$. A insurreição de Germinal começou em 27 de março na seção de Gravilliers: seiscentas mulheres acompanhadas de alguns homens se dirigiram à Convenção carregando "A tábua dos direitos do Homem" . A causa do levante não foi apenas a fome: as mulheres gritavam contra os deputados Girondinos exigindo a libertação dos "patriotas encarcerados desde o 9 termidor". Havia objetivos políticos a alcançar ${ }^{401}$. As assembléias gerais foram tumultuadas, entre outros motivos, porque as mulheres presentes desciam das tribunas para deliberar e até votar junto com os cidadãos. A revolta de Germinal não teve êxito. Mas a penúria se agravava. Crianças recém-nascidas eram abandonadas nos orfanatos (Enfants-de-lapatrie) e o número de suicídios aumentava. Só entre os dias 9 e 20 de abril, 17 corpos de suicidas foram pescados do rio. Mães desesperadas se jogavam no Sena com os filhos nos braços ${ }^{402}$. O povo estava revoltado com a falta de pão e de liberdade: "uma cidadã comentava na rua: há oito meses atrás tínhamos pão e hoje não temos mais. Estamos vivendo na escravidão" " Vejo mulheres que recebem pão de 60 gramas e ficam contentes porque não comeram nada na véspera. Se você apresentar uma petição sobre o assunto na Convenção Nacional, vai preso. As sociedades populares foram fechadas. Fizeram isso para nos mergulhar de novo na escravidão" ${ }^{403}$.

No dia $1^{\circ}$ de Prairial (20 de maio) de 1795, as mulheres iniciaram a insurreição que marcou o apogeu do movimento feminino de massa : " De manhã cedo em $1^{0}$ de Prairial repicaram os sinos no Faubourg Saint-Antoine e no Jardim das Plantas. Mais uma vez, como em outubro de 1789, foram as mulheres que tomaram a iniciativa e trouxeram os seus companheiros para a ação atrás delas" ${ }^{404}$. O mote do protesto era "Pão e Constituição de 1793!" . Desde Germinal, os relatórios diários dos observadores de polícia indicam que as mulheres tinham as propostas mais "incendiárias e sediciosas", e agiram como incitadoras, ou, literalmente, "bota-fogos" ("boute-feux" ) do movimento. O Comitê civil da Seção do Norte escreveu depois de Prairial que

\footnotetext{
401 GODINEAU, Dominique, Citoyennes Tricoteuses - Les femmes du peuple à Paris pendant la Révolution Française, Paris, Editions Alinea, Perrin, 2004 , p. 302.

402 GODINEAU, Dominique, Citoyennes Tricoteuses - Les femmes du peuple à Paris pendant la Révolution Française, Paris, Editions Alinea, Perrin, 2004 , p. 306

${ }^{403}$ Homens e mulheres do Pont Neuf lamentam o desaparecimento das sociedades populares no Ano III - Archives de la Préfecture de Police, Paris, AA 216, Section Pont Neuf, 29 Germinal, Ano III IN LEVY, Darline G., APPLEWHITE, Harriet B., JOHNSON, Mary D. - Women in Revolutionary Paris - 1789-1795 - . Selected documents translated with notes and commentary by the authors Urbana e Chicago, University of Illinois Press, 1980, p. 283.

${ }^{404}$ RUDÉ, George, The Crowd in the French Revolution , London, Oxford University Press - Oxford at the Clarendon Press., p. 152.
} 
"não vamos nos enganar; nos momentos tempestuosos que afligiram a cidade, as mulheres tiveram o papel de bota-fogos" ${ }^{405}$. As descrições parecidas se repetem: " as mulheres dizem que os homens são uns trouxas (jean-foutres) por se deixarem levar desse jeito" (24 germinal); duas mulheres foram interpeladas na porta da padaria por terem gritado que "todos os homens eram uns poltrões por não se reunirem para marchar sobre a Convenção" (28 Germinal) ; "as mulheres (...) atormentam os homens , chamando-os de covardes. (...) Um grande número dentre elas queria deflagrar a insurreição" (7 floréal) ${ }^{406}$.

Na véspera da revolta de Prairial , uma mulher teria distribuído na entrada da Assembléia Geral de Popincourt o panfleto Insurreição do povo, para obter pão e reconquistar seus direitos, que foi amplamente disseminado em Paris naqueles dias. No dia seguinte, as mulheres se reuniram em grandes grupos que iniciaram a marcha para a Convenção, arrastando os homens recalcitrantes pelo caminho, entrando nas lojas e casas para convencê-los a aderir ao levante. Alguns foram maltratados e depois se referiram a elas como "as fúrias da guilhotina (...) e suas mãos homicidas" Seguindo o ritual tradicional nas revoltas populares, algumas mulheres bateram os tambores para marcar a cadência da marcha e amotinar os parisienses ${ }^{407}$. A presença masculina era essencial, pois os homens tinham as armas, principalmente os canhões.

Godineau ressalta a dinâmica das relações masculinas e femininas: as mulheres aceitam conscientemente o papel de detonadoras da revolta, os homens as seguem com suas armas, e depois as mulheres os sustentam na luta. O aspecto relacional das insurreições populares é significativo : há uma dinâmica e uma reciprocidade específica entre os dois sexos. Esse comportamento pode ser observado em revoltas anteriores, por exemplo, no conflito com os Girondinos em maio de 1793: nesse caso não foram elas o estopim da crise , mas um observador de polícia notou o seguinte: "as mulheres têm a esperança de serem secundadas pelos homens" (13 de maio) e " as mulheres iniciarão o movimento (...) e os homens virão apoiá-las" , disse um deputado da Convenção no dia 18 de maio de 1793. A marcha para Versalhes em 5 de outubro

${ }^{405}$ GODINEAU, Dominique, "Political Practice during the French Revolution' IN Women \& Politics in the Age of the Democratic Revolution, Ann Arbor, The University of Michigan Press, 1993, p. 74

${ }^{406}$ GODINEAU, Dominique, Citoyennes Tricoteuses - Les femmes du peuple à Paris pendant la Révolution Française, Paris, Editions Alinea, Perrin, 2004 ,p. 315.

${ }^{407}$ Idem, p. 320. 
também se pautou por essa complementaridade dos sexos: as mulheres começaram a marcha, foram seguidas pelos soldados da Guarda Nacional , e em Versalhes eles tomaram a frente, sendo por sua vez acompanhados por elas ${ }^{408}$.

Em Prairial, as ativistas desarmadas, acompanhadas por uma dezena de homens, conseguiram entrar na Convenção. Esta jornada foi uma desesperada tentativa das mulheres, as quais foram maioria nesta última ocupação da Convenção. Do lado de dentro, os soldados tentavam repeli-los com armas na mão, o que gerou gritos de que as mulheres estavam sendo massacradas. Nesse momento, os homens do Faubourg Saint-Antoine e outros entraram na sala da sessão. O Moniteur relata: "às três horas e trinta e três minutos, uma multidão de mulheres e homens armados de fuzis, piques e sabres entrou na Convenção" reclamando "Pão e Constituição de 1793"409 . O deputado Féraud tentou impedir sua passagem - foi morto e decapitado, aparentemente com a participação de algumas mulheres. Mais tarde, sua cabeça foi exibida na ponta de uma lança na sala da Convenção. As reivindicações dos insurgentes eram, entre outras, a libertação dos patriotas presos, a prisão dos deputados hostis , o retorno dos deputados Montanheses detidos na revolta de Germinal, melhor controle do abastecimento na capital, novas eleições, e "Pão e Constituição de 93". O fim da escassez estava ligado, para a maioria dos manifestantes, ao fim da "tirania" e à recuperação dos direitos de soberania do povo. As militantes sans-culottes queriam punir os aristocratas, os moderados, os comerciantes, e os traidores na Convenção. Exigiam a volta do Terror ${ }^{410}$. No dia 2 de Prairial alguns batalhões da Guarda se rebelaram e apontaram seus canhões para a Convenção. As mulheres não aparecem nos relatos do levante desse dia, pois não puderam participar das reuniões nem das lutas dos Guardas. No dia seguinte, elas apelavam aos transeuntes para que atacassem a Convenção, tentaram se apoderar dos canhões, fizeram tocar os sinos para a Comuna e insuflaram a revolta, num último esforço revolucionário. No entanto, não foram chamadas para a assembléia geral da Seção que decidiu nomear uma nova Municipalidade. Prevaleceu o já tradicional limite da participação feminina nas insurreições: as mulheres desaparecem dos documentos assim que o Povo Soberano se estrutura em assembléia.

\footnotetext{
408 Ibidem , pp. 316-317.

${ }^{409}$ Idem, pp. 323-324.

${ }^{410}$ Idem , p. 326.
} 
Seguiu-se uma repressão brutal. As militantes ainda tentaram socorrer seus companheiros, mas desta vez foi em vão. Há relatos de mulheres gritando nas ruas, "como fúrias incitando os homens" : "É preciso ajudar nossos irmãos do Faubourg Antoine (...)" O governo intimou o faubourg a entregar Tinel e os canhões de três Seções. As cidadãs eram partidárias da resistência, agrupadas em todas as esquinas. Um relatório de polícia observa que: "as mulheres estão reunidas em cada rua e fazem grande barulho. O pão é a causa material da sua insurreição; mas a Constituição de 1793 é a alma" ${ }^{411}$. Em 23 de maio de 1795, esfomeado e exausto, o faubourg SaintAntoine se rendeu sem combate. Nesse momento começava o Terror Branco: uma comissão militar pronunciou 36 condenações à morte, inclusive dos 6 deputados Montanheses que estiveram ao lado dos revoltosos, 1.200 prisões, e 1.700 ordens de desarmamento; nas províncias, terroristas foram executados.; jacobinos foram destituídos, agredidos, e tiveram que fugir. Os patriotas "eram caçados como perdizes ${ }^{412}$. Dentre as 148 parisienses presas pela polícia , a maioria foi condenada a dois meses de prisão. As mães de família com filhos pequenos estavam ausentes da multidão. Tanto nos relatos masculinos, como nas deposições femininas, o dia 1 de Prairial teve características de uma jornada das mulheres ${ }^{413}$. Nas fontes policiais, elas aparecem como "bota-fogos" capazes de cometer atos violentos, apesar de a maioria ter se limitado à violência verbal. Como de costume, as mulheres se dirigiram à mais alta instância do poder nacional; ocuparam as tribunas para impedir os deputados de falar , uma tática já testada com sucesso durante a crise dos Girondinos. Não se sabe ao certo o número de mulheres na revolta, mas um relatório fala em duas mil, o que é indicação de que muitas haviam se desiludido com as manifestações populares. A multidão de Prairial foi a mais violenta e sombria de todas as jornadas femininas da Revolução: em 1789 havia esperança e fervor, em 1795 havia desespero e esgotamento. A religião católica re-emergia após a campanha de descristianização, e diante de tantas desgraças, muitas mulheres retornavam para o consolo da igreja.

\footnotetext{
${ }^{411}$ RUDÉ, George, The Crowd in the French Revolution, London, Oxford University Press - Oxford at the Clarendon Press., pp. 154-155.

${ }^{412}$ LEFEBVRE, Georges - La Révolution Française - Presses Universitaires de France, Paris, 1989, pp. 442-443.

${ }_{413}$ GODINEAU, Dominique, Citoyennes Tricoteuses - Les femmes du peuple à Paris pendant la
} Révolution Française, Paris, Editions Alinea, Perrin, 2004, p. 332. 
Sinal dos tempos, a polícia apontou duas filas perigosas na capital: uma na missa e outra na padarias (une à la messe, l'autre à la boulangerie) ${ }^{414}$.

Os decretos contra a militância feminina foram significativos: no dia 1 de Prairial, proibiu-se a presença de mulheres nas tribunas da assembléia; no dia 4, votouse a interdição de assistirem a qualquer assembléia política. Sobraram apenas as ruas como locais de encontros políticos femininos. Os deputados, entretanto, acharam que o risco ainda era grande. Assim, no dia 4, a Convenção aprovou por unanimidade uma lei ordenando que as mulheres se recolhessem aos seus domicílios: "uma hora depois do anúncio deste decreto, aquelas que forem encontradas nas ruas em ajuntamentos (attroupements) de mais de cinco mulheres, serão dispersadas pela força das armas e colocadas em estado de detenção"415. As leis de repressão dirigidas especificamente às mulheres dão a medida do temor que o movimento de massa feminino causava nos governantes termidorianos, e da preocupação que tiveram em silenciá-lo. Os relatórios de polícia após a derrota do movimento dão conta da ordem e do silêncio que reinavam em Paris. Em 9 prairial: "Submissão completa às leis da Convenção. Respeito dos homens, silêncio das mulheres" ; em 10 prairial "(...) as mulheres voltaram aos seus lares, e se tornaram mudas sobre os acontecimentos políticos" em 20 prairial: " (...) não se ouvem mais os gritos sediciosos e os clamores enlouquecidos daquelas fúrias da guilhotina" ${ }^{416}$.

Godineau chama a atenção para o fato de que as medidas não eram resultado da misoginia dos convencionais: visavam um dos componentes mais ativos do movimento popular, e não as mulheres enquanto sexo feminino ${ }^{417}$. Ao contrário, a repressão revela o papel importante das insurgentes de Germinal e Prairial: as militantes eram adversárias políticas corajosas que cobravam dos deputados promessas não cumpridas. Os políticos queriam tirar das ruas de Paris a multidão feminina porque era feminina e popular. Além disso, a classe burguesa termidoriana tentava

\footnotetext{
414 As informações deste parágrafo estão IN HUFTON, Olwen H., Women and the Limits of Citizenship in the French Revolution, Toronto, Buffalo, London, University of Toronto Press, 1992, pp. 46-50.

${ }^{415}$ GODINEAU, Dominique, Citoyennes Tricoteuses - Les femmes du peuple à Paris pendant la Révolution Française, Paris, Editions Alinea, Perrin, 2004 , pp. 330-331. 416 idem, p. 345.

${ }^{417}$ GODINEAU, Dominique, Citoyennes Tricoteuses - Les femmes du peuple à Paris pendant la Révolution Française, Paris, Editions Alinea, Perrin, 2004 , p. 331.
} 
impor a ideologia doméstica às francesas de todas as classes. Reduzidas ao silêncio, não tendo onde se reunir, as mulheres não poderiam mais incitar os homens ao levante.

Essas rebeliões marcaram o apogeu e a derrota do ativismo feminino e do próprio movimento popular ${ }^{418}$. O que restou de toda aquela experiência revolucionária? Os historiadores estão divididos quanto ao legado da militância feminina. Os atos de cidadania por elas praticados foram varridos do mapa até meados do século XIX, e o exercício pleno dos direitos políticos que as patriotas haviam imaginado só se materializou substancialmente no século XX . As francesas só acederam aos direitos cívicos após a Segunda Guerra Mundial. Catherine Marand-Fouquet acha que as ativistas não deixaram sequer o germe de uma emancipação futura - e portanto não houve nenhuma continuidade entre a Revolução e as feministas contemporâneas ${ }^{419}$. Entretanto, aqueles seis primeiros anos da Revolução ficaram na história das lutas pela cidadania e serviram de inspiração para as futuras gerações. Applewhite salienta que a Sociedade das Republicanas Revolucionárias foi o protótipo dos clubes políticos de mulheres que surgiram na revolução de $1848^{420}$. As suas duas presidentes, Claire Lacombe e Pauline Léon, foram elogiadas por defenderem os interesses das mulheres do povo de sua época. Outro aspecto digno de nota é que depois da Revolução Francesa, qualquer política de guerra tinha que atender `as necessidades particulares das mulheres: pensões para as viúvas ou esposas de mutilados de guerra, uniformes e provisões para maridos e filhos no exército, oficinas de trabalho para as mães e esposas de combatentes. A Revolução acentuou o papel das mulheres como barômetros das crises sociais. Elas tinham se acostumado a vir para as galerias das assembléias gritar e exigir providências se suas reivindicações não fossem atendidas. As leis contra a participação política feminina não apagaram a imagem que tinham de si próprias, de pessoas conscientes e conhecedoras de seus direitos. Tal atitude se construiu ao longo da Revolução, quando parecia que as mulheres tinham conquistado uma medida de liberdade. Naqueles

\footnotetext{
418 HUFTON, Olwen H., Women and the Limits of Citizenship in the French Revolution, Toronto, Buffalo, London, University of Toronto Press, 1992, pp.48-50.

${ }^{419}$ MARAND-FOUQUET, Catherine, La femme au temps de La Révolution - Paris, Éditions Stock/Laurence Pernoud, 1989,pp. 376-377.

${ }^{420}$ As informações sobre o legado das revolucionárias estão IN LEVY, Darline G., APPLEWHITE, Harriet B., JOHNSON, Mary D. - Women in Revolutionary Paris - 1789-1795 - . Selected documents translated with notes and commentary by the authors - Urbana e Chicago, University of Illinois Press, 1980, pp. 310-311.
} 
anos, pressionadas por questões de subsistência, alentadas pelos ideais da Declaração dos Direitos, elas descobriram sua força política. Eram capazes de resistir à opressão, lutar por justiça social, e intervir de forma dramática no curso da própria Revolução. Neste Capítulo 1 , procurei refletir sobre as formas pelas quais diferentes grupos de mulheres conseguiram tomar parte da vida cívica e praticar sua cidadania de integração ao Povo Soberano, até serem alijadas da esfera pública e da política nacional. 


\section{CAPITULO 2}

Representações femininas 


\section{0 - Revolução e Iconografia}

O objetivo deste capítulo é apresentar e discutir as representações iconográficas femininas durante a Revolução Francesa. As informações oferecidas pelas imagens ora confirmam as idéias expostas no Capítulo 1, ora apontam ambigüidades, ora contradizem ou relativizam teses reconhecidas. Trata-se de uma arte moral: quase todas as gravuras emitem algum tipo de julgamento em relação ao sujeito representado, o que nos leva ao campo das percepções diferentes de virtude feminina. A iconografia pode nos ajudar a compreender as práticas políticas e sociais das mulheres, e como estas foram recebidas pelos contemporâneos. Os gêneros artísticos privilegiados neste estudo são as alegorias, as caricaturas, e as aquarelas de Lesueur, a meio caminho entre a caricatura e crônica dos acontecimentos da Revolução.

"A metáfora é essa estratégia do discurso através da qual a linguagem se despe de sua função descritiva direta para aceder ao nível mítico onde sua função de descoberta é libertada" ${ }^{1}$ Paul Ricoeur

Esse pensamento de Ricoeur me chamou a atenção porque pode ser aplicado também ao exercício da leitura de imagens: é preciso ultrapassar a função descritiva mais superficial para entrar no nível mítico, onde acontecem as descobertas. Sim, é ali que se poderá desvendar outros significados e mensagens que, afinal, são o objetivo da representação. A imagem portanto, pode representar idéias políticas, valores morais ou crítica social que se quer propagar, ou inculcar na mente do público. Não obstante, a eficácia das representações depende da existência de uma psicologia coletiva propícia à aceitação de tais idéias, ou, inversamente, partindo da disseminação intensa das representações para a construção de um novo imaginário social.

Bourdieu define poder simbólico como o " poder sobre o uso particular de sinais, e deste modo, sobre a visão e o sentido do mundo natural e social', "que existe porque aquele que lhe está sujeito crê que ele existe" ${ }^{2}$.

\footnotetext{
${ }^{1}$ RICOEUR, Paul, La Métaphore Vive, p. 311 IN De Baecque, Antoine - Le Corps de l'Histoire, Metaphores et politique (1770-1800), Paris, Ed. Calmann-Lévy, p. 11
} 
Os líderes revolucionários se aperceberam do potencial de transformação desse poder simbólico, e, substituindo a religião pela política , recrutaram "apóstolos" ou "propagadores" para colocá-lo em prática. Na Revolução Francesa, fez-se uso intenso da propaganda visual para facilitar a ruptura com os valores do Antigo Regime, e edificar uma nova ordem social. Nesse novo sentido político, a propaganda fazia parte de um ambicioso programa de instrução pública para regenerar o povo francês $^{3}$. Através de concursos, a República contratou artistas que foram incumbidos da disseminação visual dos ideais republicanos. Deste modo, eles tiveram o papel de "instituidores da nação", pois seus pincéis e cinzéis estavam a serviço de uma missão gloriosa, como disse Vergniaud: "A Assembléia Nacional incentivará, com todas as suas forças, as artes, as quais, por meio de tão belo uso, poderão encorajar as grandes ações e contribuir desta maneira para a felicidade do gênero humano" 4 .

No início da Revolução, havia grande idealismo entre os artistas que ficavam liberados do "jugo" da Academia. A nação lhes concedeu prêmios de incentivo, prometeu vastos trabalhos nacionais e, sobretudo, lhes confiou uma missão inédita ${ }^{5}$. Entretanto, o termo "propaganda" pode ser considerado um tanto redutor e anacrônico quando se trata da empresa cultural da Revolução Francesa - a historiadora da arte Annie Jourdan prefere falar em "estratégias da regeneração", ou "vontade pedagógica". Segundo ela, os quadros, esboços, modelos, croquis realizados por ocasião dos concursos do Ano II testemunham as expectativas, representações e prioridades do primeiro republicanismo que a França conheceu. A esse título, eles merecem mais que

\footnotetext{
${ }^{2}$ BOURDIER, Pierre, O Poder Simbólico , Lisboa: Difel, 1989, respectivamente p. 72 (nota 16) e p. 188 IN STOIANI, Raquel, Da Espada à Águia - Construção Simbólica do Poder e Legitimação Política de Napoleão Bonaparte, São Paulo, Humanitas, 2005, p. 17.

${ }^{3}$ HUNT, Lynn, "Engraving the Republic: Prints and Propaganda in the French Revolution" History Today, no. 30 (October 1980), P. 12.

${ }^{4}$ JOURDAIN, Annie, " Les concours de l'An II - En quête d"un art républicain " IN La Révolution à l'oeuvre - perspectives actuelles dans l'histoire de la Révolution Française, Presses Universitaires de Rennes, 2005, p. 265.

${ }^{5}$ JOURDAIN, Annie, Les Monuments de la Révolution 1770-1804 - Une histoire de représentation, Paris, Editions Champion, p. 22, nota no. 28.
} 
a etiqueta de "propagandistas", pois deram origem à tradição iconográfica da República francesa ${ }^{6}$.

Novo regime político, novos símbolos. A República não podia sobreviver sem massas politicamente educadas, e para isso era preciso criar uma tradição e um repertório de símbolos republicanos., como o barrete vermelho, a Marianne deusa da

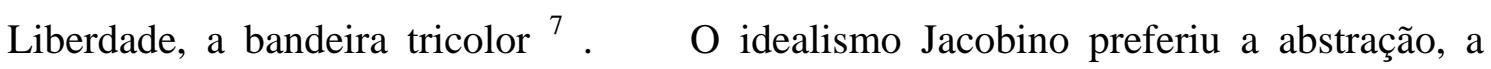
alegoria, a metáfora e imaginação à mera descrição factual, gostava do que era elevado e grandioso, como o projeto da regeneração do homem ${ }^{8}$. Assim, a alegoria saiu da cultura de elite para falar ao povo ${ }^{9}$. Não obstante, a compreensão das alegorias depende de um conhecimento erudito dos códigos de interpretação, o que não estava ao alcance de todos. Por essa razão, houve a preocupação do governo revolucionário em fornecer textos, por vezes bastante extensos, com a interpretação correta das imagens. Da fé sensualista no poder das imagens resultou uma enorme produção de pinturas, esculturas, gravuras e cartazes, além dos festivais, canções, medalhas, fitas, discursos, jornais, louça de mesa e até cartas de baralho ornamentados com os símbolos da República. Os meios mais variados foram empregados para difundir o ideário da Revolução ${ }^{10}$. O deputado Abbé Grégoire estava convencido disso quando defendeu a necessidade de imagens no novo selo da República em seu Rapport sur les sceaux de la République (1796) :

(...) Quando se constrói um governo novo, tudo deve ser republicanizado. O legislador que não reconheça a importância da linguagem dos signos seria irresponsável; ele não deveria perder nenhuma oportunidade de impressionar os sentidos para despertar idéias republicanas. Logo a alma é penetrada pelos objetos reproduzidos constantemente diante de seus olhos; e essa coleção de princípios, fatos, emblemas, reforça incessantemente para o cidadão os seus direitos e deveres, formando, por assim dizer, o molde republicano que lhe dá o caráter nacional e a postura de um homem livre $(. . .)^{11}$.

\footnotetext{
${ }^{6}$ idem, p. 278 e JOURDAIN, Annie, Les Monuments de la Révolution 1770-1804 - Une histoire de représentation, Paris, Editions Champion , pp. 13-14, nota no. 13.

${ }^{7}$ HUNT, Lynn, Política, Cultura e Classe na Revolução Francesa, (trad.) São Paulo, Cia. Das Letras, 2007 , p. 112.

${ }^{8}$ HIGONNET, Patrice, Goodness beyond Virtue, Cambridge, Massachusetts e London, England, Harvard University Press, 1998 , p. 215.

${ }^{9}$ LANDES, Joan B., Visualizing the Nation - Gender Representation and Revolution in EighteenthCentury France, Ithaca, Cornell University Press, 2001 pp. 53-54.

${ }^{10}$ HUNT, Lynn, “Engraving the Republic: Prints and Propaganda in the French Revolution” History Today, no. 30 (October 1980), p. 12.

${ }^{11}$ Citação IN LANDES, Joan B., Visualizing the Nation - Gender Representation and Revolution in
} Eighteenth-Century France, Ithaca, Cornell University Press, 2001, p. 28. 
Não é necessário percorrer todo conjunto de imagens alegóricas para perceber a preponderância da figura feminina. Há várias explicações possíveis para essa escolha: a mais óbvia é a de que os substantivos abstratos que representam são do

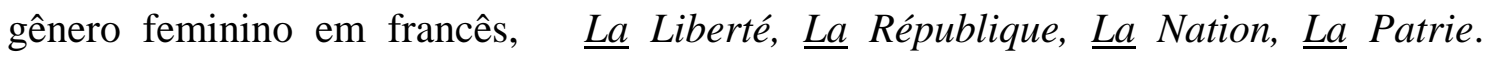
Entretanto, essa explicação é insuficiente. Desde Cesare Ripa no século XVI ${ }^{12}$, a tradição iconográfica já utilizava figuras femininas para representar qualidades abstratas. Essa coleção de imagens, organizada e reapresentada por Gravelot e Cochin no tratado Iconologie par Figures ${ }^{13}$, foi uma das fontes de inspiração dos artistas franceses da Revolução. A Antiguidade estava na moda, e nada mais apropriado que figuras da mitologia clássica para personificar as virtudes cívicas ${ }^{14}$. Indo mais além, essas representações têm múltiplos significados ligados aos papéis da mulher na sociedade. Poderiam servir de modelos de comportamento para as mulheres da época: as matronas romanas, as mães espartanas, ou os rostos virginais das "Liberdades" inspiravam valores eternos, mas dentro da austeridade da República. Além disso, era útil aproveitar o fervor religioso de grande parte da população, e sugerir a identificação das deusas pagãs com a Virgem Maria e santas católicas das procissões. A dignidade e seriedade das alegorias femininas, de certa forma representavam o ideal burguês de esposa austera, elevada e principalmente silenciosa. Dessa forma, enquanto as mulheres de carne e osso eram excluídas da vida pública, as deusas podiam ser exaltadas porque eram abstratas, coletivas, estavam acima das turbulências revolucionárias $^{15}$ - "au dessus de la melée": não votavam, não faziam petições à Assembléia nem protestavam nas ruas. Em outras palavras, não exerciam nenhum poder.

\footnotetext{
${ }^{12}$ RIPA, Cesare, Iconologia , Roma, 1593.

${ }^{13}$ GRAVELOT, H.F., COCHIN, C.N., Iconologie par figures ou Traité complet des allégories, emblèmes, etc. à l'usage des artistes en 350 figures, edições do XVIII em 1765 e 1791, edição atual: Genève, Minkoff Reprint, 1972.

${ }^{14}$ LANDES, Joan B., Visualizing the Nation - Gender Representation and Revolution in EighteenthCentury France, Ithaca, Cornell University Press, 2001, p. 17

${ }^{15}$ Idéia de Lynn Hunt IN MELZER, Sara E. And RABINE, Leslie W. (editoras), Rebel Daughters Women and the French Revolution, New York - Oxford, Oxford University Press, 1992, p. 205.
} 
Outra razão para as alegorias femininas foi o que Lynn Hunt e Antoine de Baecque $^{16}$ chamaram de "a crise política da representação". Com a destituição do Rei , quem iria representar a soberania política? Quem substituiria a pessoa, o retrato e a coroa como centro afetivo da vida política nacional? A Convenção Nacional escolheu a deusa da Liberdade para o selo oficial, e o símbolo permaneceu . A figura de uma jovem mulher, envolta em túnica romana, substituiu o retrato do Rei no selo ${ }^{17}$. Não era uma idéia nova: já na década de 1770 , a deusa da Liberdade tinha começado a aparecer nas pinturas francesas. A divindade era o oposto da imagem paternal do Rei: jovem, frágil, pura em suas vestes brancas; o Rei era humano, tinha alegrias e tristezas; o humor da República era estável. A estabilidade era um valor importante em meio às paixões revolucionárias. Isso se reflete na posição quase sempre estática das diferentes "Liberdades": a pedagogia alegórica da Revolução preferia a segurança tranqüila, que correspondia à visão de um regime confiante em seus poderes, nem ameaçador, nem ameaçado, triunfante enfim ${ }^{18}$. Enquanto a Revolução real se defendia de conspirações internas e perigos externos, o espelho alegórico representava o oposto desse discurso. Na coleção Iconologie de 1791, só 11 entre 62 figuras estavam em movimento $^{19}$. Por essa razão, a imagem romântica de uma Liberdade Guiando o Povo (Delacroix em 1831), onde a Liberdade é uma mulher do povo liderando revoltosos numa barricada, teria sido inapropriada para a época. Como vemos, a substituição do corpo sagrado do Rei pela imagem da deusa da Liberdade não é sem importância, e reflete a mudança do ideário político e social naquele contexto instável.

Não obstante, as tradições e hábitos antigos custam a morrer. Ao lado da deusa da Liberdade com um rosto anônimo, distante e fria no pedestal, desenvolveu-se uma outra Liberdade mais popular e mais próxima do povo. Esta outra podia socorrer e consolar os aflitos, como outrora fizera o Rei: "(...) a Liberdade altiva veio despertar nossos espíritos abatidos; ela fez brilhar sua chama entre nós e o doce calor

\footnotetext{
${ }^{16}$ De Baecque, Antoine, “The Allegorical Image of France, 1750-1800: A political crisis of representation” - Representations, no. 147, special issue (Summer, 1994), pp. 111-143

${ }^{17}$ HUNT, Lynn, “Engraving the Republic: Prints and Propaganda in the French Revolution” History Today, no. 30 (October 1980), p. 15

${ }^{18}$ DE BAECQUE, , Antoine, "The Allegorical Image of France, 1750-1800: A political crisis of representation” - Representations, no. 147, special issue (Summer, 1994), pp. 111-143.

19 GRAVELOT e COCHIN, Iconologie, 1791 - maior coleção de figuras alegóricas do período IN De BAECQUE, Antoine, “The Allegorical Image of France, 1750-1800: A political crisis of representation” - Representations, no. 147, special issue (Summer, 1994), p. 127
} 
que em nossas almas penetrou, fez germinar a semente das virtudes (...)"20. Há uma tentativa de humanizar e corporificar o ideal da Liberdade, a ponto de lhe darem um nome católico comum entre os franceses, significando o ideal ao alcance de todos. Assim, Marianne, a Liberdade-República, com o tempo, virou personagem símbolo da França. A figura feminina foi preferida à dos líderes revolucionários vivos, envolvidos nas disputas políticas. Enquanto Mirabeau, Lafayette e muitos outros desapontaram seus seguidores e desapareceram da cena histórica, a Liberdade perdurou, graças à sua abstração e impessoalidade ${ }^{21}$.

Ao mesmo tempo que se tentava humanizar a deusa, havia um movimento para "sacralizar", por assim dizer, os símbolos da Revolução. A Declaração dos

Direitos do Homem e do Cidadão, os hinos patrióticos, sermões cívicos e juramentos constitucionais passaram a ser tratados com uma veneração quase religiosa ${ }^{22}$. Fiz alguns comentários sobre o assunto na figura 5, "O Pudor". A respeito dessa transferência de sacralidade da antiga religião para objetos cívicos, vale a pena lembrar Tocqueville, que já havia percebido tal característica da Revolução:

Como ela parecia tender à regeneração do gênero humano mais ainda que à reforma da França, ela acendeu uma paixão (...) inspirou o proselitismo e fez nascer a propaganda. Assim, ela pode se dar aquele ar de revolução religiosa que tanto assustou os contemporâneos; mais que isso, tornou-se ela própria uma espécie de religião nova, religião imperfeita, é verdade, sem Deus, sem culto e sem outra vida, mas que não obstante, como o islamismo, inundou toda a terra com seus soldados, seus apóstolos e seus mártires ${ }^{23}$.

Lynn Hunt observou que no início da Revolução havia muitas gravuras mostrando cenas de multidões patrióticas, sugerindo o engajamento da nação inteira na fundação do novo Estado. Muitas imagens incluíam as mulheres. Utilizei várias gravuras ou aquarelas com esse tema, para analisar em que medida o povo teria ou não sido heroicizado. De 1789 a 1792, as cenas de violência coletivas eram bem recebidas, mas depois disso, tornaram-se um tanto assustadoras - era preciso restabelecer a tranqüilidade. Com a proclamação da República em setembro de 1792,

\footnotetext{
${ }^{20}$ New York Public Library, microficha 9.4/40.

${ }^{21}$ HUNT, Lynn. "Hercules and the Radical Image in the French Revolution", Representations, no. 2 (Spring, 1983) pp. 95-117 - JSTOR., p. 98.

${ }^{22}$ LANDES, Joan B., Visualizing the Nation - Gender Representation and Revolution in EighteenthCentury France, Ithaca, Cornell University Press, 2001 p. 55.
}

${ }^{23}$ TOCQUEVILLE, Alexis de , L'ancien régime et la Révolution, Paris, Gallimard, 1967, p.71. 
os rostos serenos das deusas alegóricas paulatinamente substituíram as multidões $\operatorname{agitadas~}^{24}$.

Mas ao mesmo tempo, havia também imagens contra-revolucionárias, ou até de revolucionários contrários às mulheres militantes, que mostravam a República como Medusa, bruxa ou tricoteira terrível, no gênero caricatural. As caricaturas eram veículos ágeis e tiveram um papel na propaganda política. Produzidas e distribuídas no mercado rapidamente, no calor do momento, também faziam a história, segundo J. Landes. Consequentemente, nota-se que a qualidade artística desses trabalhos varia muito. Como observa Michel Vovelle:

embora a caricatura tome emprestadas uma parte de suas figuras da cultura popular (inversão carnavalesca, ênfase no corpo e suas funções naturais), e se dirija mais a essa camada de público que a um círculo de iniciados, ela não deixa de ser o trabalho de artistas que não são ingênuos e pertencem a um aparato organizado de produção, apoiados por um discurso não raro bastante elaborado ${ }^{25}$.

Tanto a caricatura quanto a alegoria são sensíveis à opinião pública e ajudam a criar o que Baecque chama de imaginação popular ou imaginário político. Por sua vez, os artistas foram inventando um universo de símbolos e figuras junto com o desenrolar dos acontecimentos, não havia nada pré-estabelecido. Por exemplo, a idéia da árvore da liberdade veio dos camponeses que queriam se declarar livres dos impostos que pagavam aos senhores nobres. Autoridades do governo gostaram da idéia e inventaram a cerimônia da plantação da árvore para celebrar a Revolução. Até maio de 1792, 60.000 árvores da liberdade tinham sido plantadas na França ${ }^{26}$.

Conforme anunciei no capítulo introdutório, incluí algumas aquarelas do artista Lesueur nesta dissertação. Esses trabalhos fazem parte de uma série de 64 pinturas cuja finalidade precisa ainda não foi estabelecida. Talvez tenham sido criadas para posterior gravação e distribuição; ou encomendadas por um particular; ou quiçá o

\footnotetext{
${ }^{24}$ HUNT, Lynn, “Engraving the Republic: Prints and Propaganda in the French Revolution” History Today, no. 30 (October 1980), p. 14.

${ }^{25}$ Vovelle, Michel, prefácio de La Caricature révolutionnaire (Antoine de Baecque) II - Langlois, Claude, La Caricature contre-révolutionnaire (Paris, 1988) IN LANDES, Joan B., Visualizing the Nation - Gender Representation and Revolution in Eighteenth-Century France, Ithaca, Cornell University Press, 2001 , p. 53 e Notas, p. 193.

${ }^{26}$ HUNT, Lynn, "Engraving the Republic: Prints and Propaganda in the French Revolution” History Today, no. 30 (October 1980), p. 12.
} 
objetivo fosse servir de cenário para um teatro em miniatura. O aspecto didático das imagens fala em favor de um projeto de difusão. O Museu Carnavalet as classifica como " crônica em imagens da Revolução Francesa" . De fato, a coleção é um registro de fatos e personagens interpretados pelo artista, o qual criou uma imagem idealizada da Revolução, atenuando pelo traço e pela cor qualquer sinal de violência. Há algumas características em comum entre as imagens populares e a coleção Lesueur: o formato em série e uma ingenuidade - aparente - no estilo. As pinturas de Lesueur são, no entanto, de qualidade muito superior aos desenhos ditos populares da mesma época.

Um aspecto relevante é que, enquanto as imagens são, grosso modo, contemporâneas dos fatos retratados, o mesmo não ocorre com as etiquetas explicativas. Isso fica bem claro pelo uso dos verbos no imperfeito, denotando tempo passado, e pelos erros históricos grosseiros de datas, nomenclatura, e ortografia. Philippe de Carbonnières, diretor do Museu, acha que tais erros são incompatíveis com um pintor educado ilustrando precisamente a Revolução - portanto, as etiquetas não apenas são posteriores à execução das pinturas, mas elaboradas por outras pessoas mais jovens, que talvez nem tivessem nascido na época evocada. Lesueur vinha de família burguesa razoavelmente abastada, e há razões para se supor que politicamente tenha sido um moderado, próximo dos Girondinos : gostava da Revolução, mas temia os excessos da sans-culotterie , e condenou claramente o Terror. De maneira geral, apresentou as mulheres numa luz favorável, especialmente em cenas de devoção, filantropia , maternidade, sacrifício, papéis essencialmente femininos e apreciados pela sociedade da época ${ }^{27}$.

Visto que existem milhares de gravuras da época revolucionária, selecionei uma amostragem que me pareceu representativa das tensões sociais, imaginário político e idéias de gênero do fim do século XVIII na França. Indicarei a procedência de cada imagem - bibliotecas, museus ou bibliografia - o autor e a data, sempre que possível, lembrando que grande parte dos desenhos é anônima, como foi dito anteriormente. A pesquisa detalhada dos artistas e colecionadores, sua motivação, assim como a circulação dessa produção fogem ao alcance do presente trabalho.

\footnotetext{
27 Informações sobre o pintor Lesueur IN CARBONNIÈRES, Philippe de, Lesueur - Gouaches
} Révolutionnaires - Collections du Musée Carnavalet, Paris, Paris-Musées, 2005, pp. .38-55. 
2.1 - CADERNO DE IMAGENS 


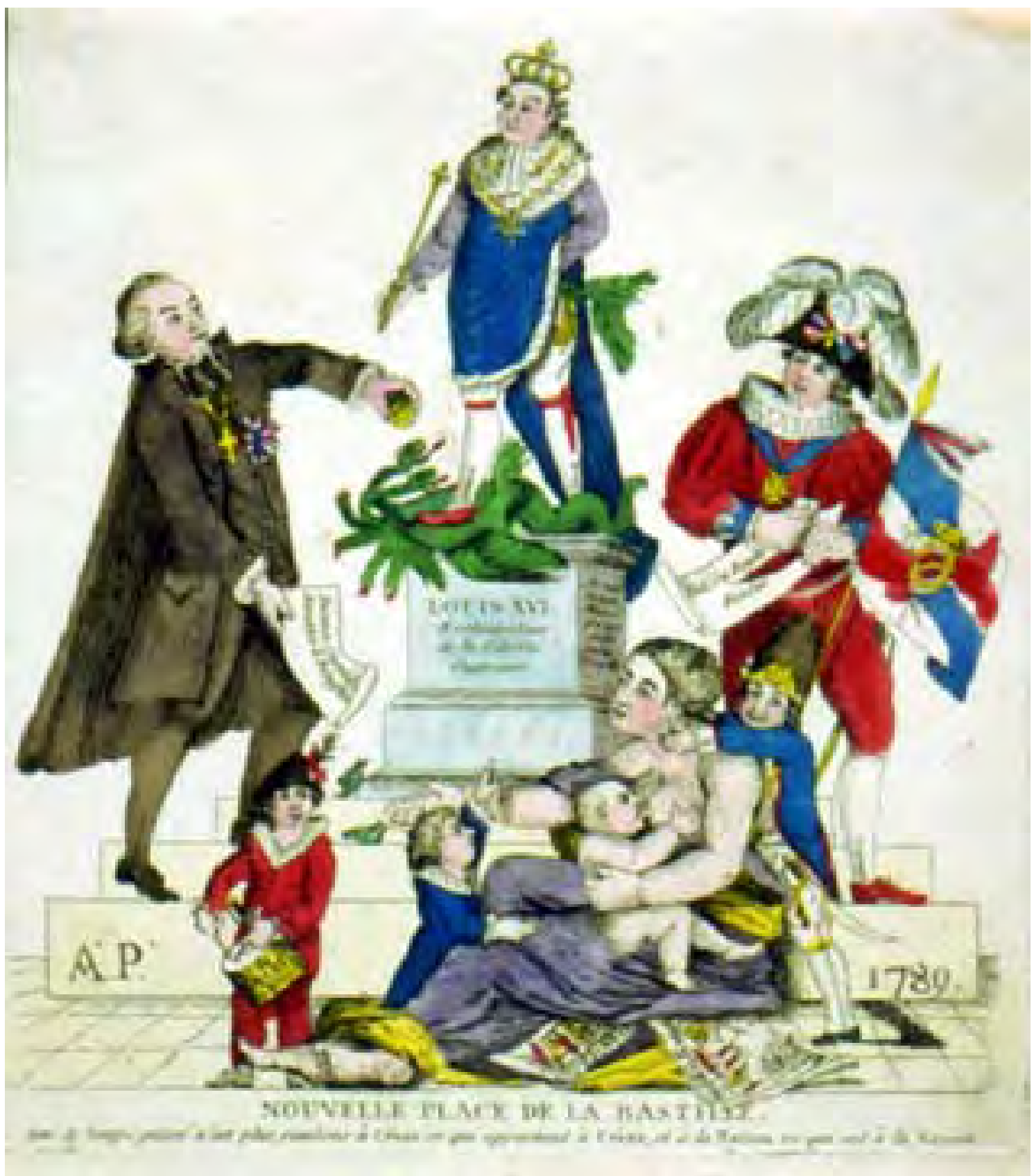

Figura 1 - Nova Praça da Bastilha - Luís XVI, Restaurador da Liberdade Francesa.

Na pintura Nova Praça da Bastilha (fig.1), celebrando 1789, nota-se o início da crise de representação. O Rei está muito menor que os personagens à sua volta, principalmente a mulher, proporcionalmente maior que os mesmos personagens. À medida que o Rei perdia prestígio e autoridade, os símbolos da monarquia foram aos poucos sendo substituídos. A efígie do monarca começou a ser preterida pela figura

\footnotetext{
${ }^{28}$ GUTWIRTH, Madelyn, The Twilight of the Goddesses - Women and Representation in the French Revolutionary Era - New Jersey, Rutgers University Press, 1992 pp. 253-254.
} 
materna , novo símbolo da nação. Assim mesmo, os dizeres proclamam Luís XVI "restaurador da liberdade", e ele é retratado pisando sobre a hidra da tirania. De fato, depois da Marcha de outubro, quando o Rei e sua família voltaram para Paris escoltados pelas mulheres e pela Guarda Nacional, houve um ressurgimento do prestígio do monarca. É uma época de transição. Vemos um rei que "encolheu", junto com sua autoridade , e uma mulher que "cresceu" na medida da exaltação da maternidade. A mãe está na base do pedestal, na base da sociedade. Há uma incongruência entre o tamanho do Rei e os dizeres "restaurador da liberdade"; se o monarca fosse um herói restaurador, teria outra estatura física e uma postura mais altaneira. A pátria é representada pela mãe que gera e amamenta futuros cidadãos soldados que irão defendêla quando crescerem. É a mulher cumprindo seu papel na nova sociedade; percebe-se a importância social do aleitamento materno, colocado no centro do desenho, para onde convergem os olhares. Os meninos (só filhos homens) já estão se preparando para seu papel de soldados tocando tambor, e usando chapéu e farda militar, são os novos heróis da nação. A legenda inscrita na parte mais inferior da imagem diz: "Assim, o tempo que passou terminou; devolvamos a César o que é de César e à Nação o que é da Nação" (Ainsi le temps passé n"est plus. Rendons à Cesar ce que appartient à Cesar et à la Nation ce que est à la Nation.). O religioso e o nobre estão devolvendo à Nação o que lhe tinham usurpado. Vejamos: à esquerda do pedestal há um religioso devolvendo com a mão esquerda uma moeda, e no texto da mão direita há uma explicação: são os "dízimos, [ilegível], anatas, benefícios" que a igreja recebia. À direita do pedestal está a nobreza, que segura um texto: “fim do regime feudal'; a figura tem os atributos da condecoração no peito, a espada, o brasão, o chapéu de plumas, o culote. A roupa do nobre não é a da época, parece um traje do Renascimento italiano, com gola de renda do século XVI, o chapéu do XVII que lembra o dos mosqueteiros de Luís XIII. A mistura faz o personagem ficar ridículo, como se fosse um jogral da corte. O nobre era agora uma figura de carnaval. Há uma visão idílica da reconstrução social, todos cooperam voluntariamente. A mãe está no centro, é a peça chave da reconstrução. Há uma ruptura com o passado, isto é, com o nobre, o religioso e até o Rei nanico, e a inauguração de uma nova era : a mãe enorme e seus quatro filhos vigorosos. 


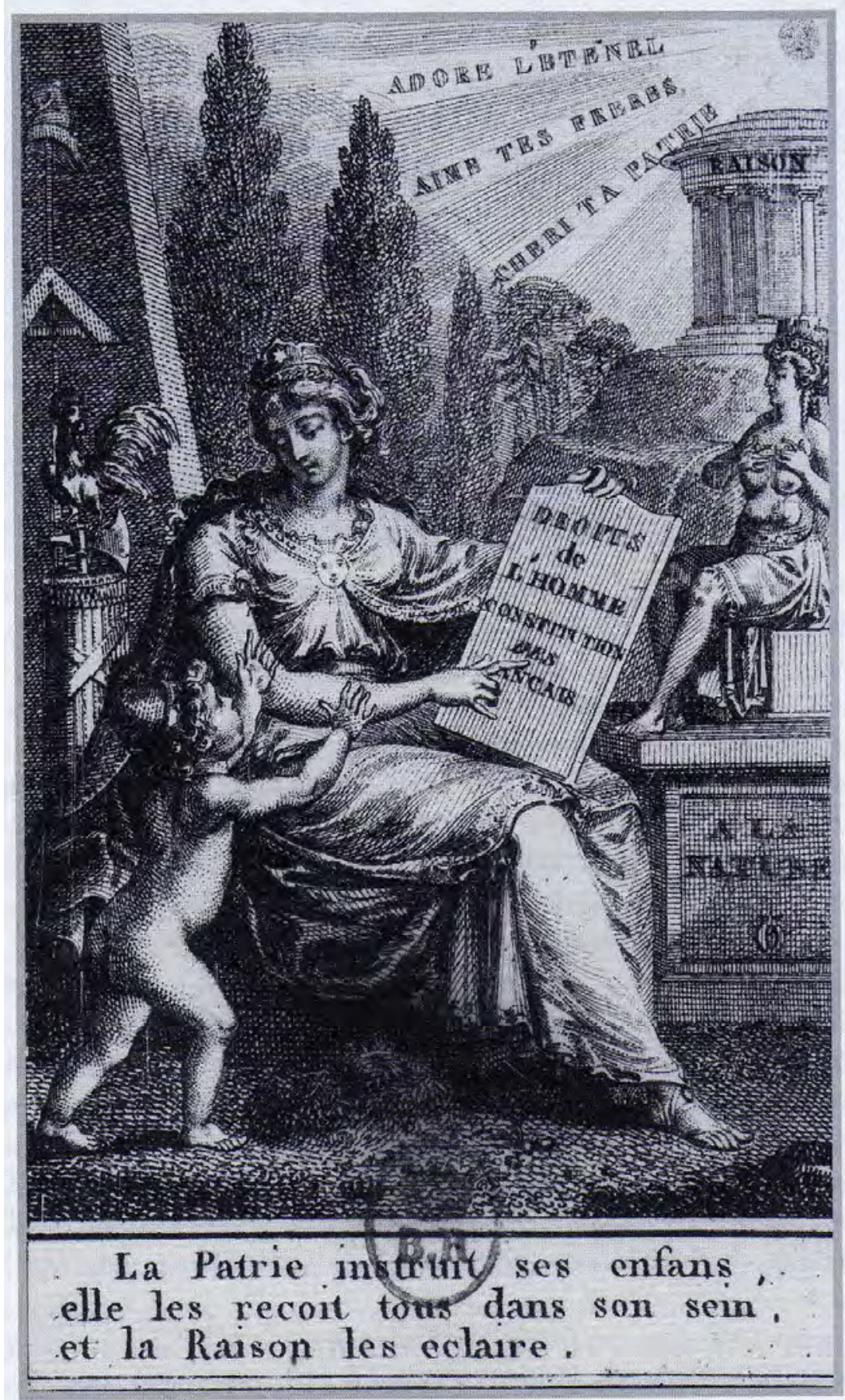

Figure 4.II. The Fatherland Instructs Its Children, She Receives All of Them in Her Bosom and Reason Enlightens Them. ca. 1793. Courtesy of the Bibliothèque nationale de France.

Figura $2{ }^{29}$ A Pátria instrui seus filhos, recebe a todos em seu seio, e a Razão os ilumina.

\footnotetext{
${ }^{29}$ LANDES, Joan B., Visualizing the Nation - Gender Representation and Revolution in EighteenthCentury France, Ithaca, Cornell University Press, 2001
} 
Aqui entramos no terreno das alegorias, com a primeira delas, A Pátria instrui seus filho, recebe a todos em seu seio, e a Razão os ilumina (fig. 2) . O ambiente é da Roma clássica. A mãe Pátria ensina ao menino com ares de Cupido os preceitos máximos da nação. Há uma identificação proposital da personagem principal com a Virgem Maria ou Sant"Ana, e também a Razão. A mãe Pátria aponta para a Tábua contendo "Os Direitos do Homem e Constituição dos Franceses" , objeto quase sagrado , como se fosse as Tábuas da Lei com os 10 Mandamentos. A criança saúda o ensinamento com entusiasmo porque está sendo esclarecida pela Razão. Á esquerda, na sombra, vê-se os símbolos da Revolução: os fasces, representando a união, o galo francês, a nação, o nível maçônico da igualdade, uma pique , símbolo do povo armado, com o barrete frígio da liberdade espetado na ponta. Do lado direito, a deusa Diana da caça e da fertilidade, com múltiplas tetas simbolizando fertilidade, no pedestal que diz "Natureza": a mulher está próxima da natureza pois dá à luz, nutre e regenera - e este é seu papel na sociedade. No alto da colina, um templo redondo romano dedicado à Razão e os dizeres em forma hierárquica: o mais alto: "adore o eterno", depois "ame seus irmãos” e por último, "estime sua pátria". Há dois sóis, um no céu, outro no peito da Virgem, representando o esclarecimento, a iluminação das trevas da ignorância, num espírito iluminista. Durante a Revolução, a hierarquia dos dizeres se inverteu: o culto ao ser supremo, "ao eterno" foi efêmero, e ficou restrito aos líderes revolucionários, não teve ressonância real entre a população; em compensação, o amor à pátria subiu para o primeiro lugar, e os irmãos ficaram onde estavam, em segundo lugar.

Esta alegoria promove a maternidade cívica, exaltando o papel educador da mãe republicana . É ela que vai formar os futuros patriotas, ensinando-lhes os mais elevados princípios morais e políticos, contidos na Declaração de Direitos do Homem e do Cidadão e na Constituição dos Franceses (como está escrito nas Tábuas da Lei). A mãe nutriz é a ligação entre a Nação e as futuras gerações. A mãe Pátria também é endeusada, na medida em que poderia ser uma deusa romana ou a Virgem Maria mas igualmente devido à sua missão quase sagrada. Há uma mistura de símbolos: o galo gaulês, explicado na próxima figura (3), os da antigüidade clássica, como os fasces, que na Roma antiga representavam o poder triplo de punição dos lictores, as cintas para prender, as varas para bater, e o machado para decapitar se necessário; a deusa Diana, o amuleto da Pátria, que se parece à Medusa pendurada no peito da deusa Palas Atena, o barrete frígio ostentado pelos escravos libertos em Roma; um símbolo maçônico, o 
nível da igualdade; símbolos revolucionários: a pique, a Declaração dos Direitos do Homem. Símbolos católicos: a sabedoria divina nos raios de sol, que representam também a palavra de Deus. Tocqueville concordaria com esta representação da Revolução, que sacraliza os símbolos políticos leigos, e se "dá ares de uma religião nova".

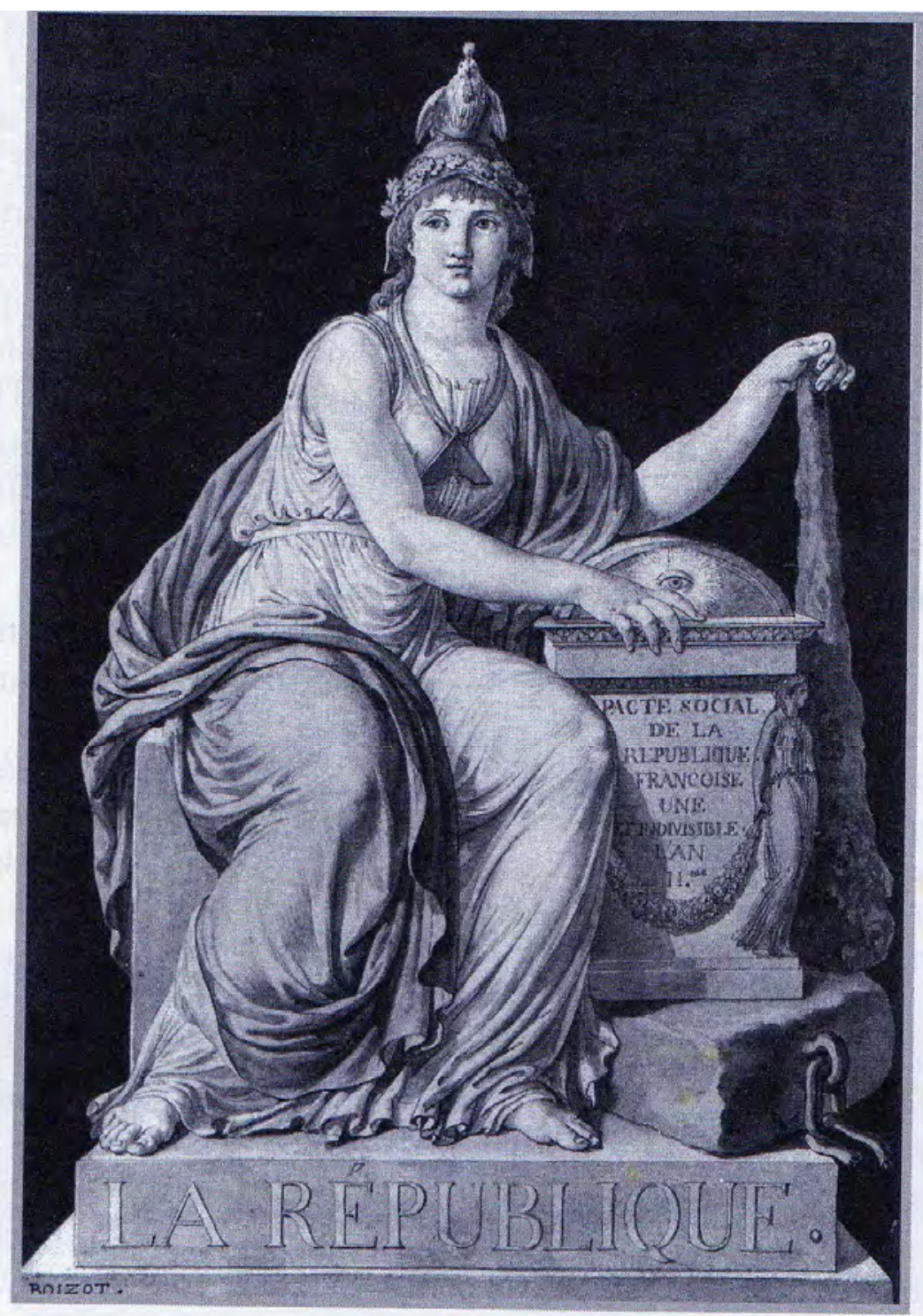

Figure 4.6. Louis-Simon Boizot, An Allegorical Figure of the French Republic. 1792. Source: 1789: French Art during the Revolution, exhibition organized and catalog edited by Alan Wintermute (New York: Colnaghi, 1989), 100.

Figura 3 - A República $^{30}$ - Pacto social da República Francesa una e indivisível Ano II.

\footnotetext{
${ }^{30}$ LANDES, Joan B., Visualizing the Nation - Gender Representation and Revolution in EighteenthCentury France, Ithaca, Cornell University Press, 2001 , p. 152
} 
Esta alegoria de Boizot A República - Pacto social da República Francesa una e indivisível, Ano II. (fig. 3) foi encomendada para celebrar a queda da monarquia e a instauração da República em setembro de 1792 . A República está vigilante contra os perigos - sua posição e seu olhar parecem ter detectado alguma ameaça, que podem justificar o uso da violência - da clava - se for preciso. O olho egípcio e o galo simbolizam a vigilância; o nível maçônico no peito, a igualdade; a coroa de louros a virtude cívica e a vitória da República sobre a monarquia.

Vale a pena explicar sucintamente a simbologia do galo gaulês: ele representa ao mesmo tempo o país e a nação, como no Antigo Regime, mas também o Estado protetor ou o Povo vigilante. Depois de 1792, essa ave ocupa cada vez mais espaço. Para os homens do Ano II, o galo velava pela segurança da República. Nos meses de Terror, os cata-ventos senhoriais eram abatidos, mas os galos nos telhados das igrejas, apesar de serem símbolos fortemente cristãos (S. Pedro e Jesus), foram poupados, pois viram nele uma figura benéfica que protegia os cidadãos. $\mathrm{E}$ o galo permanecia bem gaulês, ligado ao povo. No século XVII, Père Ménestrier, polígrafo e teórico incansável na área dos símbolos e emblemas, explicava que os gauleses, povo livre e orgulhoso, haviam escolhido o galo como símbolo, não pelo jogo de palavras gallus/Gallus, mas porque o animal era por excelência a figura da coragem e da vitória $^{31}$. Para os homens da Revolução, assim como para os homens das Luzes, os gauleses passavam por ser os ancestrais dos servos e vilões, ao passo que os invasores francos seriam os antepassados dos nobres. A Revolução libertou os antigos servos, e o galo canta a libertação do povo.

A cadeia quebrada representa a libertação do povo que antes era escravo. A figura é feminina, mas forte, determinada; ela está tranqüila em sua majestade, mas não apática , as pernas esboçam um movimento lateral e se for preciso ela se põe de pé num piscar de olhos. Seu braço direito é musculoso, está pronto para a luta. Na coluna lateral há um desenho de uma escultura em pedra, que reforça a idéia da solidez, da firmeza , da vitória inabalável da República. Considerando a presença simultânea do galo e do olho, eu diria que esta República é a sentinela que protege a nação dos perigos. A clava de Hércules reforça tal impressão, pois está ligada à imagem do

\footnotetext{
${ }^{31}$ PASTOUREAU, Michel, Les emblèmes de la France, Paris, Editions Bonneton, 1998, verbete coq, pp. 62-83.
} 
povo alerta, forte e apto a se defender. Não o ataquem, porque ele revida! objetivo da alegoria é inspirar coragem e determinação, e assegurar a tranqüilidade aos cidadãos.

\section{Embodiments of Female Virtue}

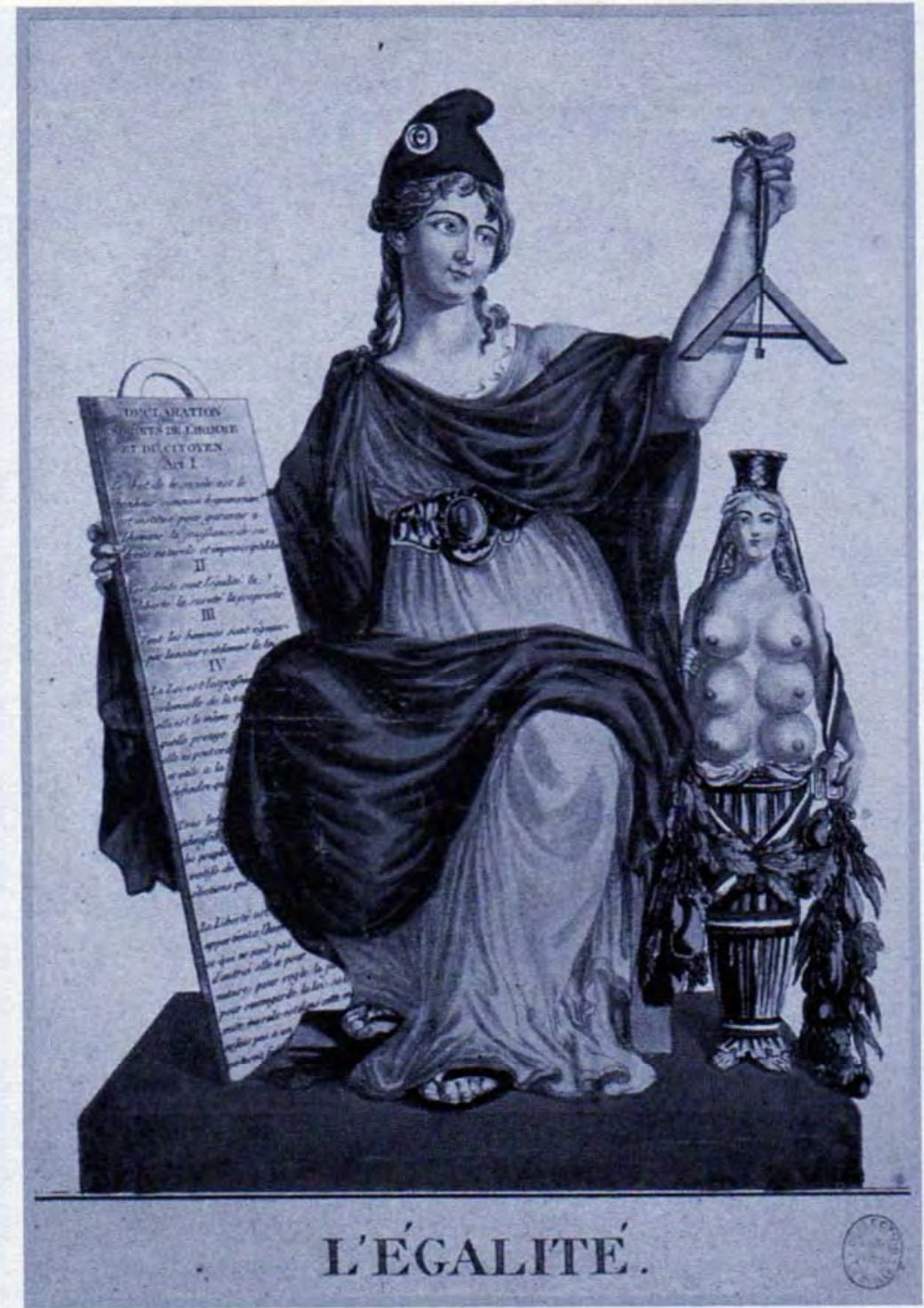

Figure 3.10. Chez Deny, Equality. Courtesy of the Musée Carnavalet. Copyright Photothèque des musées de la ville de Paris.

Figura 4 - A igualdade ${ }^{32}$ - Encarnações da virtude Feminina

\footnotetext{
${ }^{32}$ LANDES, Joan B., Visualizing the Nation - Gender Representation and Revolution in EighteenthCentury France, Ithaca, Cornell University Press, 2001 p. 103
} 
A alegoria $\boldsymbol{A}$ Igualdade (fig. 4) apresenta uma variedade de símbolos: o barrete frígio enfeitado com a cocarda da Liberdade e da República, o nível da igualdade pendurado numa fita tricolor, símbolo da França, as Tábuas da Lei com a Declaração dos Direitos do Homem e do Cidadão- referência religiosa às Tábuas da Lei que continham os 10 Mandamentos . A deusa Diana com múltiplas tetas remete à idéia de fertilidade, abundância na colheita e regeneração social - idéia associada ao papel da mulher na sociedade. A pose da figura sentada lembra as representações de Justiça com a balança, além de simbolizar a estabilidade e a paz. Há aqui algumas contradições : chama a atenção o fato de uma mulher representar a Igualdade pois ela não era considerada igual ao homem, do ponto de vista social, cívico, legal, intelectual e biológico, como esta dissertação já demonstrou. A Revolução tentou corrigir tal situação em parte, promulgando as leis civis que deram mais direitos à mulher na família. A figura da Justiça, implícita no nível de carpinteiro ${ }^{33}$ onde estariam as balanças, tampouco combina com o sexo feminino, considerado sensível demais, exaltado demais, incapaz das meditações profundas necessárias para tomar decisões sobre o bem alheio ou o bem público. Em compensação, a cocarda e o barrete frígio simbolizam o patriotismo revolucionário da Igualdade, muito prezada pela sansculotterie. As militantes populares usavam a cocarda, defendiam a Declaração dos direitos e a Igualdade fervorosamente, mas quando puseram na cabeça o barrete frígio, atributo masculino, foram acusadas de querer subverter a ordem dos gêneros. A alegoria impessoal podia usar o barrete, mas não as mulheres de carne e osso.

\footnotetext{
33 símbolo maçon: o nível do carpinteiro significa igualdade.
} 


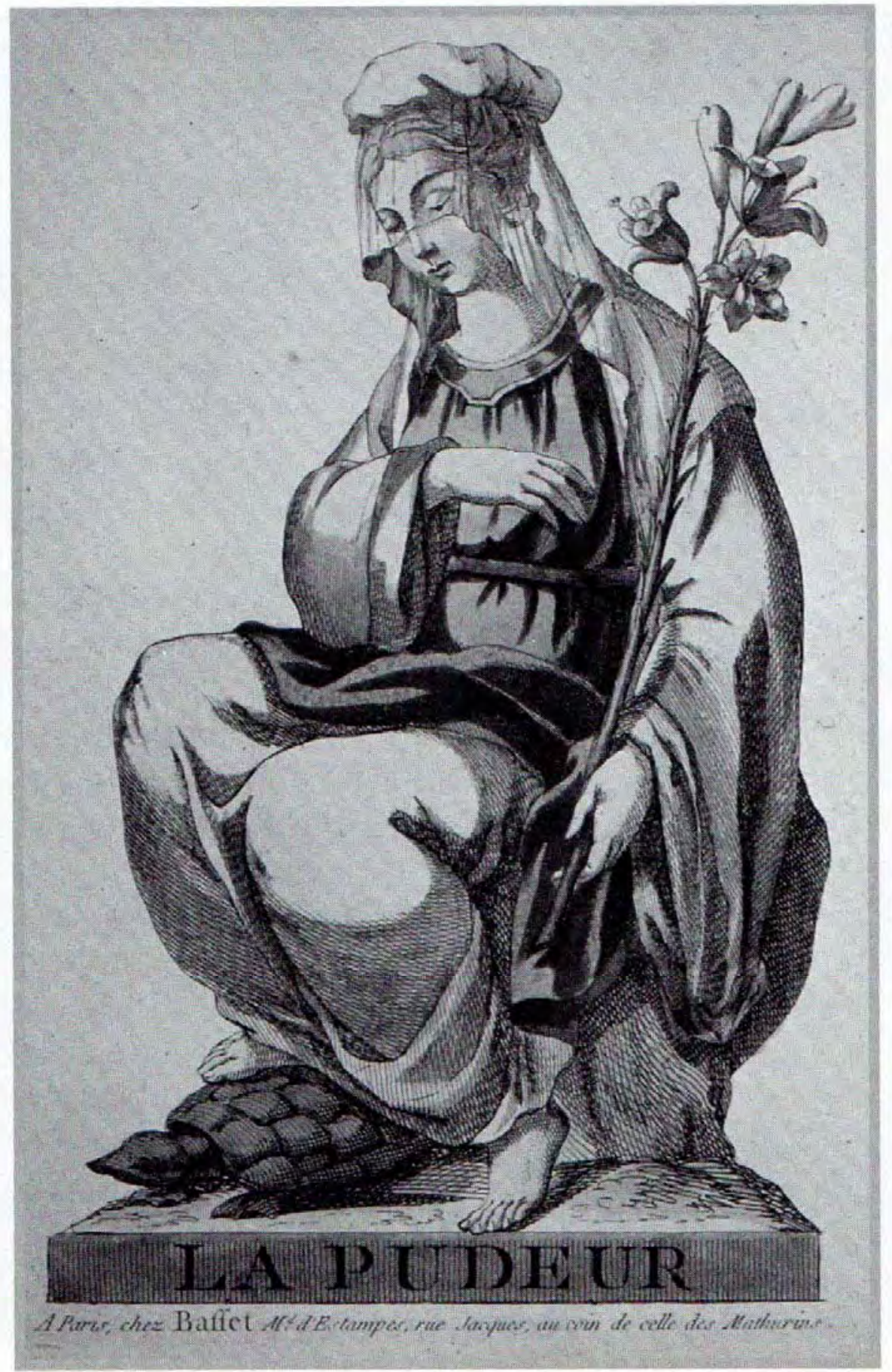

Figure 3.13. Chez Basset, Modesty. ca. 1794. Courtesy of the Musée Carnavalet. Copyright Photothèque des musées de la ville de Paris.

Figura 5 - $\underline{\text { P Pudor }}^{34}$

\footnotetext{
${ }^{34}$ LANDES, Joan B., Visualizing the Nation - Gender Representation and Revolution in EighteenthCentury France, Ithaca, Cornell University Press, 2001 , p. 106.
} 
Esta gravura $\boldsymbol{O}$ Pudor (fig. 5) é um bom exemplo do uso que a Revolução fez da iconografia católica. Vemos aqui uma Virgem Maria ao estilo renascentista, com o véu transparente florentino. A túnica e o lírio são símbolos de pureza; a tartaruga sujeita com o pé representa a existência material, e talvez a sexualidade feminina ${ }^{35}$. Os olhos baixos denotam recato e discrição, atributos da mulher honesta. As atitudes cristãs em relação à sexualidade feminina coincidiam com a dos Jacobinos inspirados em Rousseau. No projeto da regeneração moral da sociedade, o pudor da mulher era uma qualidade importante, pois as mulheres formavam a moral e os bons costumes na próxima geração. Estavam na base da República da Virtude. A Virgem era um modelo de comportamento feminino a ser imitado, pois encarnava a devoção materna, o sacrifício e a resignação. Por que não aproveitar a tradição da antiga religião para incentivar esses valores nas mães republicanas? Ao mesmo tempo, havia grande contraste entre Maria e as deusas da Liberdade. Em vez da clava, o lírio da pureza, em vez de confiança desafiadora, a humildade. A Liberdade é ela própria heroína, enquanto a Virgem é a mãe do Herói, como seria desejável para as mães republicanas. A Virgem aceita seu destino e obedece, a Liberdade não se conforma, luta por uma causa e vence. As duas "libertam", mas por caminhos diferentes. São modelos contraditórios reveladores das tensões revolucionárias. Isso não passou despercebido pelas mulheres mais religiosas e contra-revolucionárias. Para elas, o culto às deusas era terreno demais, um simulacro vazio da fé. No ano II, o Moniteur , na tentativa de sacralizar os símbolos revolucionários em substituição aos santos do cristianismo, aconselhava as parturientes a rezar para a Constituição a fim de aliviar suas dores ${ }^{36}$. Mas nesse momento crucial, as mulheres rezavam para a Virgem Maria, que era conhecida, afetuosa, e há séculos oferecia consolo e compaixão às devotas. As divindades antigas eram geladas, sem vida, sem humanidade - para não falar da Constituição - e nunca poderiam competir com a mãe de Jesus Cristo.

\footnotetext{
${ }^{35}$ LANDES, Joan B., Visualizing the Nation - Gender Representation and Revolution in EighteenthCentury France, Ithaca, Cornell University Press, 2001, pp. 105-106.

${ }^{36}$ HUFTON, Olwen H., Women and the Limits of Citizenship in the French Revolution, Toronto, Buffalo, London, University of Toronto Press, 1992, pp. 108-110.
} 


\section{Possessing La Patrie}

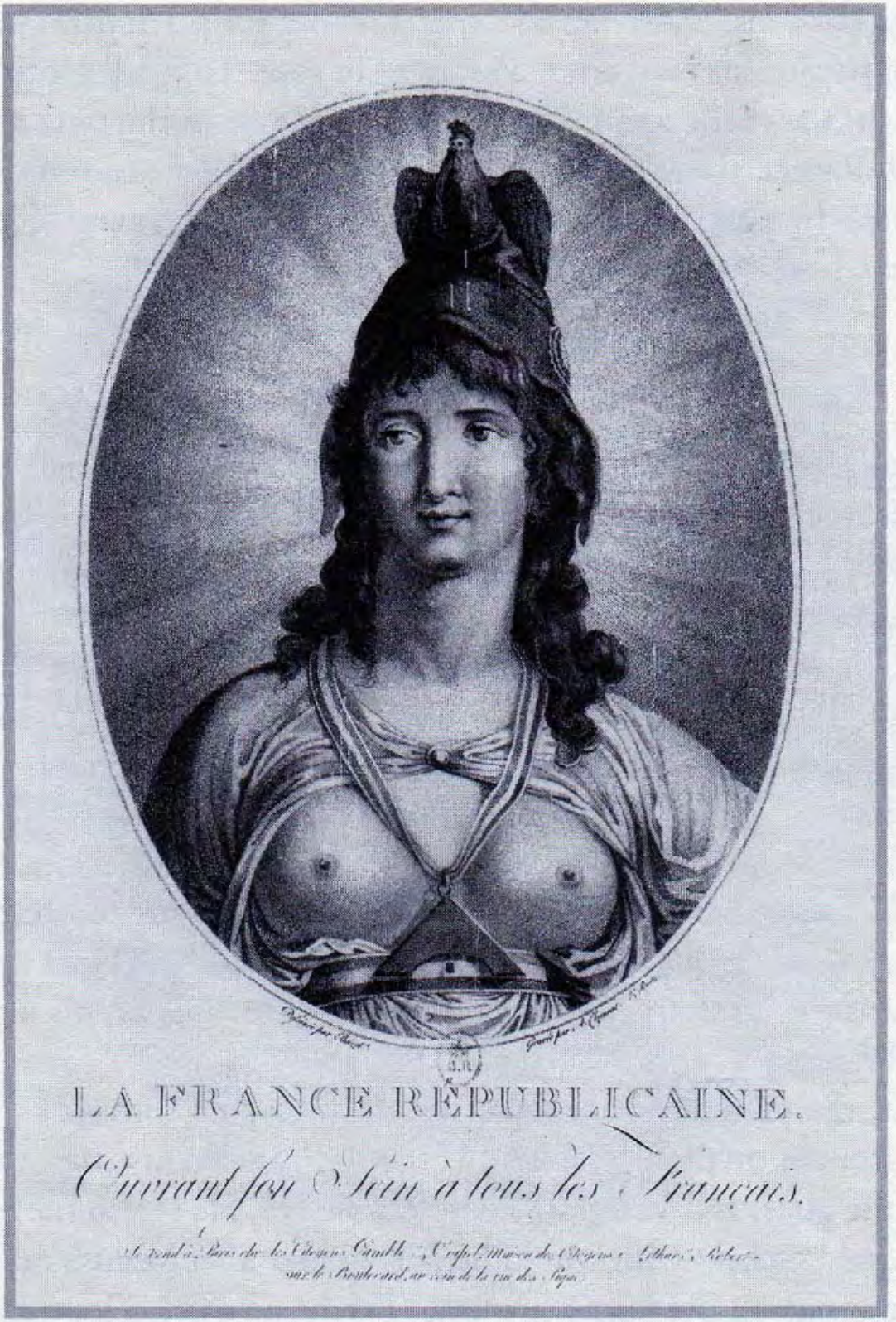

Figure 4.7. Alexandre Clément, after Louis-Simon Boizot. Republican France/Opening Her Breast to All the French. 1792. Courtesy of the Bibliothèque nationale de France.

Figura 6 - $\underline{\text { A França Republicana abrindo seu seio a todos os Franceses }}{ }^{37}$ De Louis-Simon Boizot.

\footnotetext{
${ }^{37}$ LANDES, Joan B., Visualizing the Nation - Gender Representation and Revolution in Eighteenth-
} Century France, Ithaca, Cornell University Press, 2001 , p. 153. 
A mãe que amamenta seus filhos se tornou uma das imagens mais poderosas da França Republicana. Nesta França Republicana abrindo seu seio a todos os franceses (fig. 6) o nível maçônico (triângulo de carpinteiro) indica igualdade de acesso à mãe nutriz que a todos recebe ${ }^{38}$. A alegoria exibe os mesmos atributos da Igualdade: o galo da vigilância, o nível da igualdade , o barrete frígio, a fita tricolor nacional e o sol do esclarecimento. O rosto é virginal, mas a pose é ousada . Madelyn Gutwirth enxerga aqui um símbolo sexual democrático, e diz que " Os emblemas da Liberdade ali são uma piada: ela está reduzida aos seus seios. E a figuração deixou de significar a caridade universal para ser apenas o erotismo masculino" ${ }^{39}$. Há uma ambigüidade nesta imagem, a qual reflete as atitudes dos líderes republicanos a esse respeito. Se por um lado tachavam de imoral o uso do apelo sexual para fins políticos, porque lembrava o mundo do Antigo Regime, alguns homens aconselharam as mulheres do clube de Ruffec a fazerem exatamente isso: " usem a força irresistível de suas insinuações para abrandar o coração de pedra que o doce nome da Liberdade não consegue mover" ${ }^{40}$ • Para Joan Landes, o corpo sedutor da França Republicana convida ao abraço de seus admiradores masculinos ${ }^{41}$. Eros é a ligação entre a paixão privada e o dever público. É possível, porém acho que não podemos esquecer o título, o qual sugere que a República é mãe generosa e acolhe todos os franceses como filhos. Ela oferece a todos sua proteção; em tempos conflituosos, ali está um porto seguro. Talvez seja um apelo à unidade, em nome da qual a República está disposta a esquecer as dissensões políticas. Além disso, a imagem também reforça a ideologia da maternidade republicana, que era um conceito ousado, pois revestia os cuidados maternos ancestrais de uma dimensão política nova. Em todo caso, não é o tipo de postura feminina que a ideologia da domesticidade promovia para as mulheres do mundo real.

\footnotetext{
38 MELZER, Sara E. And RABINE, Leslie W. (editoras), Rebel Daughters -Women and the French Revolution, New York - Oxford, Oxford University Press, 1992 , p. 62.

${ }^{39}$ GUTWIRTH, Madelyn, The Twilight of the Goddesses - Women and Representation in the French Revolutionary Era - New Jersey, Rutgers University Press, 1992, pp. 365-366. ${ }^{40}$ DESAN, Suzanne - "Constitutional Amazons: Jacobin Women"s Clubs in the French Revolution” IN Re-creating Authority in Revolutionary France, edited by Bryant T. Ragan, Jr.and Elizabeth A. Williams, New Brunswick, New Jersey, Rutgers University Press, 1992 , pp. 25-26.

${ }^{41}$ LANDES, Joan B., Visualizing the Nation - Gender Representation and Revolution in EighteenthCentury France, Ithaca, Cornell University Press, 2001, pp. 152-154.
} 


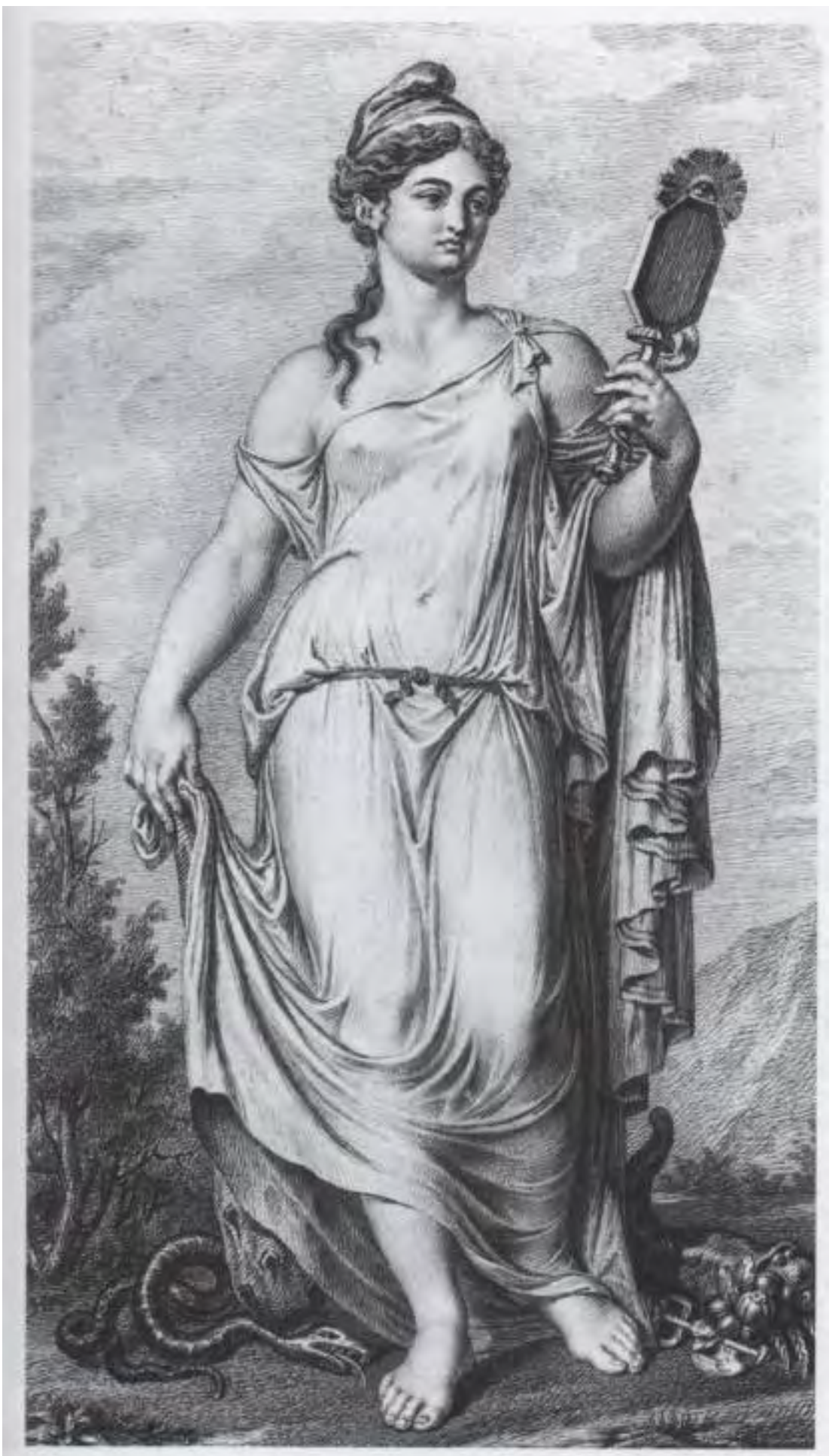

11. L'allégorie de la Liberté, dessin de Beauvallet (Vizille, Musée de la Révolution française, inv. 88-79).

Figura $7^{42}$ Alegoria da Liberdade, desenho de Beauvallet (Museu da Revolução Francesa em Vizille, inv. 88-79)

42 JOURDAN, Annie, Les Monuments de la Révolution 1770-1804 - Une histoire de représentation - figura no. 11 do Caderno de Imagens. 
Esta Liberdade (fig. 7) também é ousada e contraditória. A beleza clássica faz lembrar a Afrodite de Cnido, de Praxíteles, século IV A.C. . A imagem mostra dois atributos masculinos, a clava de Hércules e o barrete da liberdade, e dois atributos femininos, o espelho e a túnica transparente. Não é usual uma representação da Liberdade em movimento, e menos ainda caminhando sem olhar para onde vai, alheia ao entorno, enquanto se admira no espelho. A atitude denota vaidade e sensualidade, qualidades criticadas e apreciadas em doses iguais pelos revolucionários franceses. Esta Liberdade é uma personagem dividida entre o dever e a autocontemplação. Há um olho da vigilância em cima do espelho, o que é bastante intrigante. Estaria o olho vigiando a personagem ? Seria a voz da consciência , chamando-a ao dever? Ou representa a Revolução vigiando as mulheres, para que mantenham sua virtude? A deusa segura com a mão direita ao mesmo tempo a clava e a ponta da túnica, deixando entrever a perna e os pés. Sob eles, a serpente ou hidra jaz derrotada, e pode-se pensar que depois dessa vitória da força, simbolizada pela clava de Hércules, é possível haver abundância, representada pela cornucópia. Depois de aniquilar o passado - o Antigo Regime - a Liberdade traz a renovação, a regeneração, a procriação - a República - simbolizadas pelos atributos femininos. A alegoria é ambígua, parece transmitir valores não republicanos, como a imodéstia, o narcisismo e certa alienação da realidade Por outro lado, essas fraquezas tornam a personagem mais humana, alguém que não está no pedestal, mas andando descalça na terra. Esta Liberdade é menos deusa e mais mulher. 


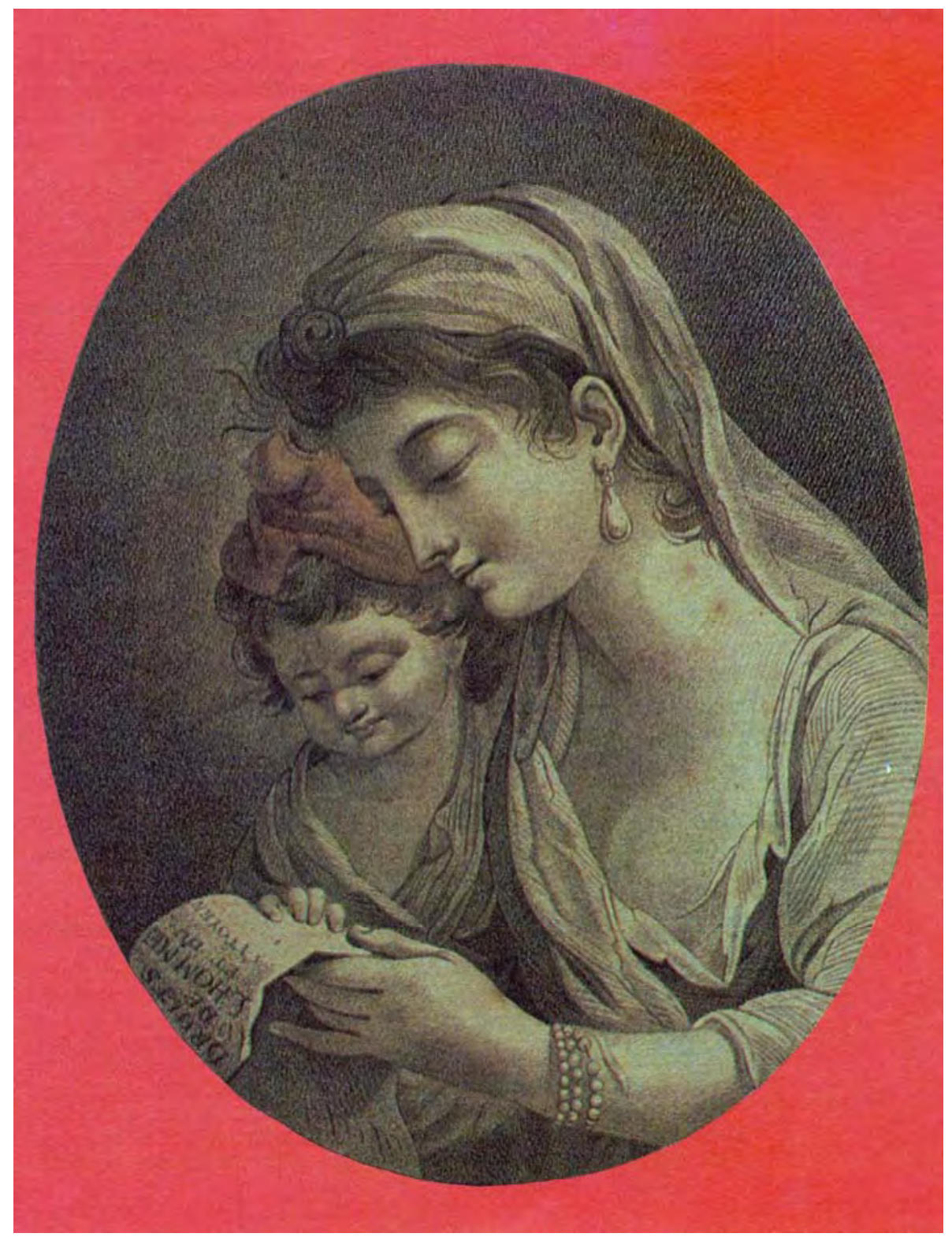

\section{Figura 8. Professora republicana ${ }^{43}$ - Chez L'Epicier, circa 1793, Cortesia}

\section{Biblioteca Nacional da França.}

A figura é a de uma mestra maternal, mas também poderia ser a de uma mãe educadora, que lê para seu aluno-filho a Declaração dos direitos do homem e do cidadão. O menino é o futuro cidadão já usando o barrete frígio da liberdade, aprendendo os princípios republicanos. A lição é importante, e tanto a mestra como o aluno estão completamente absortos no texto fundamental da nação. Para sua idade, a criança está bastante interessada, como convém a um cidadão sério. A figura materna

\footnotetext{
${ }^{43}$ LANDES, Joan B., Visualizing the Nation - Gender Representation and Revolution in EighteenthCentury France, Ithaca, Cornell University Press, 2001 p. 159
} 
também é a Pátria que acolhe seus filhos, e os nutre com espírito público e seu amor, simbolizado pelo seio que amamenta. A mestra tem perfil romano, acentuado pelo manto na cabeça, evocando tanto as mães da antigüidade romana constantemente lembradas na Revolução, como também as santas católicas, Sant"Ana - padroeira das professoras, e a Virgem Maria. As jóias são um toque de feminilidade, indicando a diferenciação dos sexos, cara aos revolucionários franceses. A mestra maternal ou mãe educadora cumprem exatamente a função que se espera das boas cidadãs: estão em casa cuidando do filho com desvelo. Na filosofia rousseauniana, é o papel que a natureza reservou às mulheres. A Revolução acrescentou uma dimensão cívica à maternidade, e fica sub-entendido que qualquer coisa que as afaste de sua missão fundamental prejudica a família e a sociedade.

A seguir, veremos duas imagens da Fonte da Regeneração, erigida para o festival de 10 de agosto de 1793, que marcou o paroxismo da campanha do aleitamento materno. 


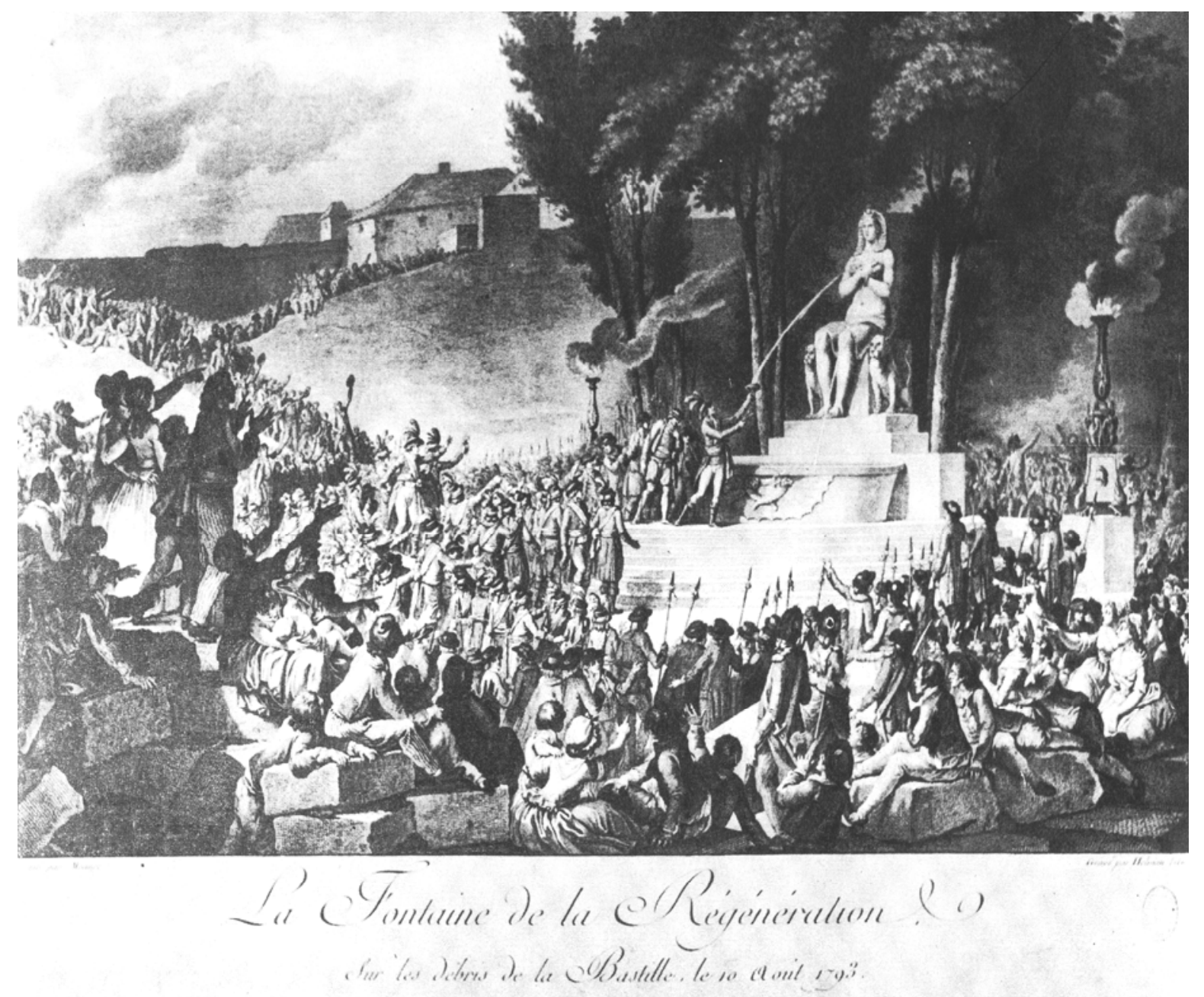

La Fontaine de la Régénération ", gravure de Helman d'après Monnet, Bibl. Nat. Paris, photo Tristant.

42

Figura 9. $\quad$ A Fonte da Regeneração sobre os escombros da Bastilha, em 10 de agosto de $1793^{44}$

A Fonte da Regeneração sobre os escombros da Bastilha em 10 de agosto de 1793

(fig. 9) e (fig. 10) foi uma das estações erigidas na Festa da Unidade e Indivisibilidade, planejada pelo pintor e deputado Jacques-Louis David, e pelo compositor Gossec. Todos os símbolos são significativos: o local escolhido para o festival era onde outrora havia se situado a Bastilha; em vez da odiada masmorra onde definhavam as vítimas do regime monárquico, agora havia uma fonte da regeneração, pois a República tinha o projeto de instilar a virtude nos franceses. A divindade homenageada é a egípcia Hathor entronada num pedestal gigantesco. O veículo da transformação é o leite materno, que para os efeitos do festival era água. Os seios de

\footnotetext{
${ }^{44}$ VOVELLE, Michel, La Révolution Française: Images et Récit, 5 vols , Paris CNRS, 1988
} 
Hathor ${ }^{45}$, deusa da maternidade, amamentação, amor feminino, natureza e fertilidade, jorram o leite prodigioso, considerando a enormidade da tarefa de regenerar a sociedade. Na imagem vêem-se os guardas com suas piques separando as autoridades dos espectadores. Só os dignatários presentes bebiam do "leite" de Hathor , o povo ficava olhando de longe. Os espectadores eram casais, grande número de mulheres, muitas mães com seus filhos pequenos, e à esquerda se vê uma que amamenta o bebê sentada. O entusiasmo geral simboliza a alegria da nação livre, a vitória sobre a tirania, e o povo unido em torno de seus líderes. Trata-se de uma gravura propagandística de Monnet-Helmann.

${ }^{45}$ GUTWIRTH, Madelyn, The Twilight of the Goddesses - Women and Representation in the French Revolutionary Era - New Jersey, Rutgers University Press, 1992, ; 364-365. 


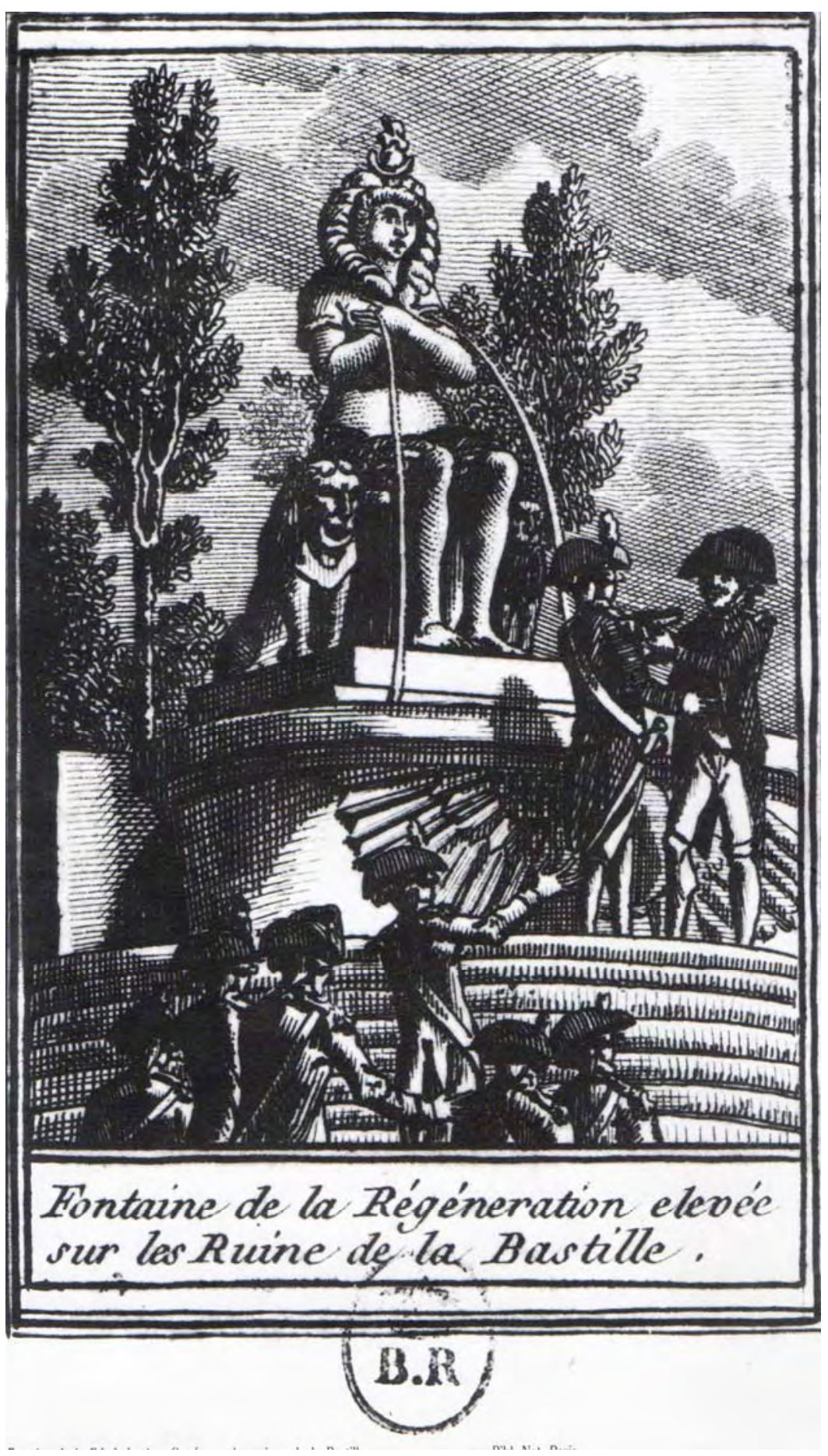

${ }^{46}$ Fig. 10 - Fonte da Regeneração construída sobre os escombros da Bastilha

A figura 10 mostra a mesma Fonte da Regeneração em 10 de agosto de 1793, mas à menor distância. A deusa da maternidade está protegida por dois mastins, assim como as mães francesas precisavam da proteção do Estado. Nesta imagem se vê melhor os líderes revolucionários simbolicamente aparando o leite de Hathor em cálices.

\footnotetext{
${ }^{46}$ VOVELLE, Michel, capítulo 7, Les femmes dans la Révolution, La Révolution Française: Images et Récit, 5 vols , Paris CNRS, 1988.
} 


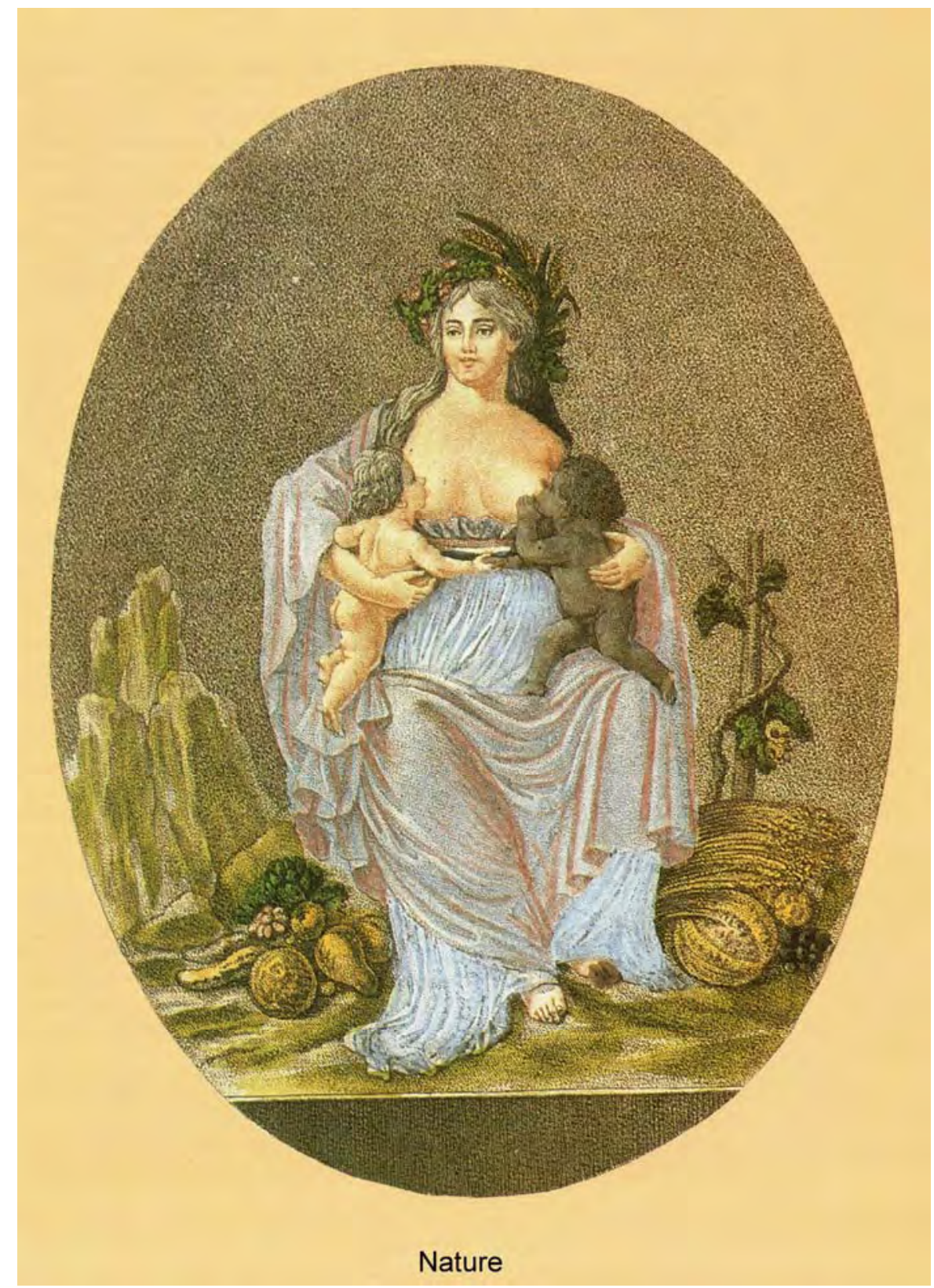

Figura 11 - $\underline{\text { A Natureza }}^{47}$ - chez Basset, Nature, ca. 1794. Musée Carnavalet.

A alegoria Natureza mostra uma figura feminina majestática aleitando duas crianças de etnias diferentes. Os atributos da personagem são os da abundância , dádivas da deusa grega da agricultura Deméter ou da romana Ceres: folhas de louros e espigas de trigo, frutas, legumes e feixes de cereais, e uma videira ao fundo. A montanha pode simbolizar o partido radical dos Montanheses da Convenção Nacional $^{48}$. Olhar vago, a Natureza não olha para os bebês: alimenta-os com a

\footnotetext{
${ }^{47}$ ROSA, Annette, Citoyennes, Paris, Messidor, 1988

${ }^{48}$ LANDES, Joan B., Visualizing the Nation - Gender Representation and Revolution in EighteenthCentury France, Ithaca, Cornell University Press, 2001, p. 103-105.
} 
naturalidade da mãe que acolhe as crianças sem distinguir a cor da pele. Na ordem natural, brancos e negros são irmãos de leite - é a civilização que os separa. A MãePátria não faz diferença entre seus filhos-cidadãos, abrigando a todos em seu regaço. A alegoria da República muitas vezes traz uma coroa de louros na cabeça, e dessa forma, a imagem também evoca a República plácida e triunfante, que traz a regeneração da terra e da espécie humana. Esta República ou Mãe-Pátria proclama ideais universais. A deusa regenera o povo francês pondo em prática um conceito radical de Igualdade que chega a derrubar a barreira racial. Há ainda o aspecto político: em nome dos direitos dos indivíduos à liberdade, a escravidão foi abolida em 4 de fevereiro de 1794, e na primavera mais de trezentos clubes Jacobinos felicitaram a Convenção pela medida ${ }^{49}$. Muitos políticos proeminentes já haviam condenado o sistema escravagista. Condorcet declarou em 1792 que não apenas o tráfico negreiro, mas a própria escravidão eram crimes anti-naturais. Brissot foi um dos membros fundadores da Sociedade dos Amigos dos Negros em 1788, e percebeu logo no início da Revolução que os princípios da Declaração dos Direitos do Homem e do Cidadão eram incompatíveis com a escravidão. Na França havia menos de cinco mil indivíduos negros, mas nas colônias do Caribe os escravos eram a maioria da população, e estavam na base da produção do açúcar, café e algodão. Os escravos negros de Santo Domingo, futuro Haiti, interpretaram a Revolução Francesa a seu modo: os "escravos brancos" da França tinham se rebelado e matado seus senhores para retomar suas terras e se governarem sozinhos. Considerando-se igualmente justificados, eles se insurgiram contra os senhores brancos em $1791^{50}$. Penso que a alegoria Natureza , de circa 1794, mesmo ano da abolição, exalta a liberdade de todos e a fraternidade entre brancos e negros - e indiretamente festeja a Convenção, simbolizada pela "montanha" à esquerda. Era interessante naquele momento frisar a importância política da igualdade de direitos para os cidadãos negros. Talvez a abolição contentasse os ex-escravos e freasse o ímpeto de independência da colônia de Santo Domingo? Tal não ocorreu, mesmo porque em 1802 Napoleão reinstituiu a escravidão nas colônias. Em 1804 o Haiti venceu a guerra de independência, separando-se da França. A pintura, entretanto, lembra um marco importante da política Jacobina e a cena do aleitamento materno representa perfeitamente os princípios

\footnotetext{
${ }^{49}$ HIGONNET, Patrice, Goodness beyond Virtue, Cambridge, Massachusetts e London, England, Harvard University Press, 1998 , pp. 98-100.

${ }^{50}$ Slavery and the Haitian Revolution, http://chnm.gmu.edu/revolution/chap8a.html, acesso 29/9/2009.
} 
revolucionários da Liberdade, Igualdade e Fraternidade. Havia, de fato, uma dimensão política na maternidade republicana.

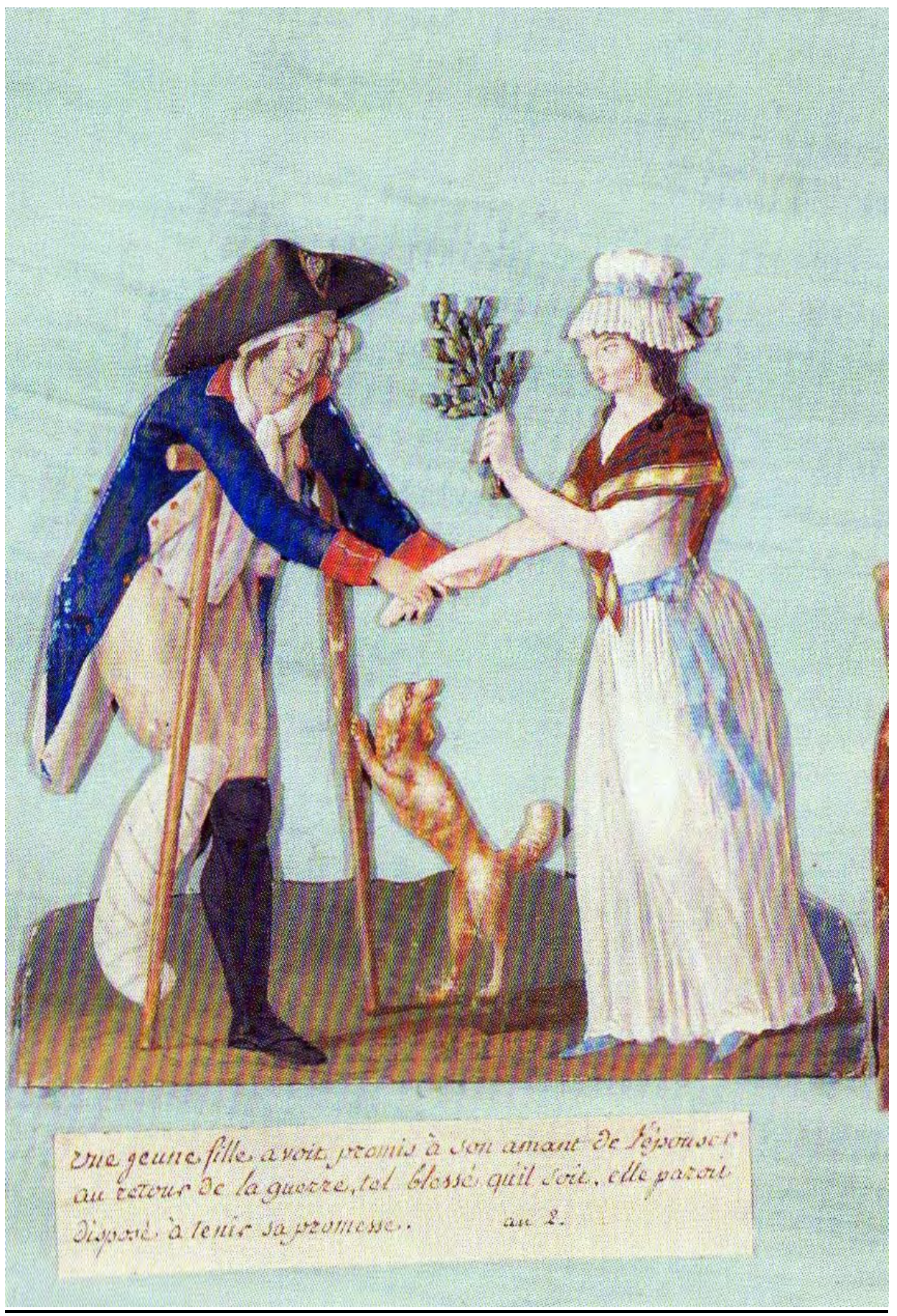

Figura 12. Uma jovem havia prometido ao seu amante de se casar com ele quando retornasse da guerra , mesmo que estivesse ferido, e parece disposta a cumprir sua promessa. ${ }^{51}$. Aquarela de Lesueur.

\footnotetext{
${ }^{51}$ CARBONNIÈRES, Philippe de, Lesueur - Gouaches Révolutionnaires - Collections du Musée Carnavalet, Paris, Paris-Musées, 2005 , fig. 39
} 
Depois dos Festivais celebrando o aleitamento materno, temos aqui algumas cenas de família: Uma jovem havia prometido ao seu amante... (fig. 12). Trata-se do retorno do soldado ferido na guerra . Com a perna atingida, talvez esteja incapacitado, mas encontra a noiva à sua espera com um ramo de louro, reservado aos vitoriosos. O tradicional gesto das mãos entrelaçadas entre os noivos significa doação e compromisso mútuo. A noiva mantém sua promessa de casar-se com o soldado, por mais ferido que estivesse. O cão é o símbolo tradicional da fidelidade na $\operatorname{arte}^{52}$. A constância da noiva é um prêmio ao patriota ferido na guerra. A moça está vestida de branco, cor da pureza , cor das republicanas. A virtude cívica leva à felicidade na vida privada. . O casal tem qualidades republicanas: ele arriscou a vida e sacrificou sua saúde pela nação, voltou para procurar a noiva, revelando honestidade, amor e devoção. Ela esperou pacientemente, pois sabia que o noivo estava lutando pela França. Recebeu o noivo como um herói vencedor e cumpriu a promessa feita no passado: ela também se sacrificou pela nação demonstrando espírito público. Os dois se comportam bem na vida privada, o que faz deles bons cidadãos, de acordo com a definição de virtude revolucionária. Os republicanos são freqüentemente retratados com uma mulher apaixonada ao seu lado. Segundo a ideologia republicana, os patriotas são viris, corajosos e virtuosos, - é natural que as mulheres se apaixonem por eles. A opção política influencia a vida privada. As mulheres reais , por sua vez, declararam várias vezes no início da Revolução que só se casariam com os patriotas que cumprissem a Constituição, conforme mencionei anteriormente.

\footnotetext{
${ }^{52}$ CARBONNIÈRES, Philippe de , Lesueur - Gouaches Révolutionnaires - Collections du Musée Carnavalet, Paris, Paris-Musées, 2005.
} 


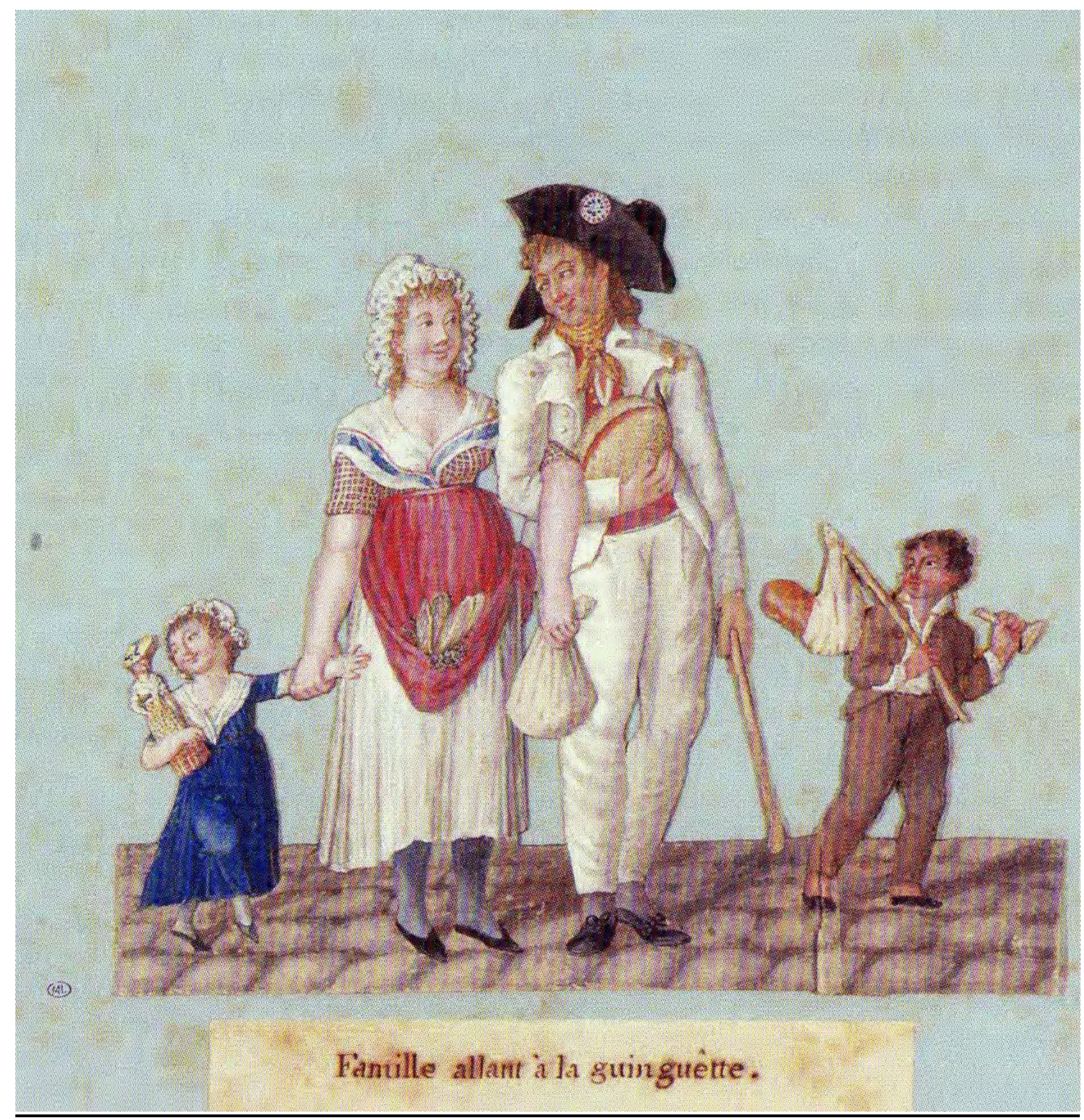

Figura -13 Família indo para a guinguette. ${ }^{53}$ (restaurante popular com música) Aquarela de Lesueur. Carnavalet.

Aqui vemos uma família de sans-culottes indo a um restaurante popular, chamado "guinguette", onde também há música e dança. A aquarela foi pintada entre 1792-1795. Como grupo social, a sans-culotterie é heterogênea, a família retratada não é nem de pequenos patrões, nem de desempregados. O homem poderia ser um artesão-marceneiro, gesseiro ou padeiro, e sua mulher costureira ou lavadeira Eles estão endomingados: a mulher sorridente usa um bonito vestido e sapatos, o marido usa uma écharpe combinando com a camisa, e trocou a pique pelo bastão, para o caso

\footnotetext{
${ }^{53}$ CARBONNIÈRES, Philippe de , Lesueur - Gouaches Révolutionnaires - Collections du Musée Carnavalet, Paris, Paris-Musées, 2005 fig. 51.
} 
de alguma briga na guinguette ${ }^{54}$. A família está bem provida de alimentos, levando pão, legumes. O menino trouxe sua corneta, preparando-se desde cedo para o papel futuro de soldado. A menina leva a boneca, também se preparando para a maternidade quando crescer. O menino é mais independente, anda sozinho e ajuda a levar o pão. Ele presta atenção nos pais. A menina parece mais nova que o irmão, e é conduzida pelo braço pela mãe, que a segura com firmeza, , olha para sua boneca e vem saltitando pela rua - as meninas têm que ser controladas mais de perto. O casal troca um olhar de ternura. Todos parecem felizes: estão sorridentes, bem alimentados, bem vestidos e aproveitando um momento de lazer. As crianças vivem uma infância despreocupada. O homem republicano é bom marido e bom pai , sua mulher é apaixonada por ele. Cada um desempenha exatamente o papel que se espera para seu sexo e idade, vivem de acordo com a moral republicana. Inclusive se nota que o homem está ligeiramente inclinado para o lado da mulher, demonstrando carinho, que ela aceita discretamente, como Rousseau preconizava na Carta a d'Alembert. Não há sinal algum de rebeldia, nem uma pálida alusão a reivindicações de qualquer natureza: na nova sociedade republicana, há abundância, paz e harmonia familiar. Os republicanos são felizes porque honestos na vida privada e bons cidadãos na vida pública. A lealdade à República traz a felicidade na vida familiar e vice-versa. Parece-me que esta família de Lesueur é um tanto idealizada: é assim que a burguesia desejava ver os sansculottes - limpos, arrumados, felizes e, acima de tudo, pacíficos. Um espelho de si própria.

\footnotetext{
54 idem, p. 208.
} 


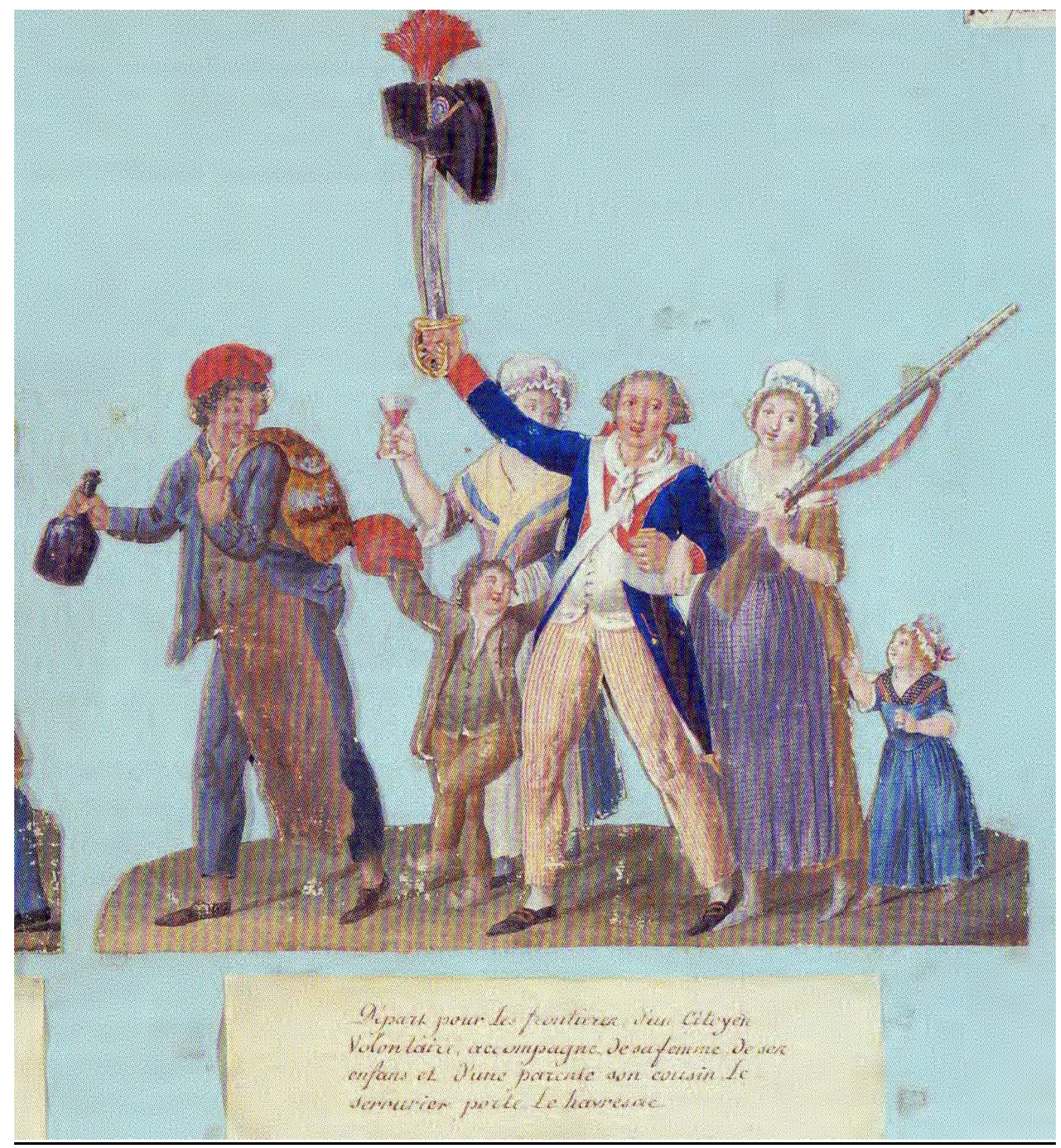

Figura 14 - Partida para a Fronteira de um cidadão voluntário, acompanhado de sua mulher, seus filhos, e um parente, seu primo serralheiro que leva o embornal. Aquarela de Lesueur, Museu Carnavalet. ${ }^{55}$

A seguir, há duas cenas bem diferentes retratando a partida de voluntários para a guerra (fig 14 e fig. 15) A primeira pintura (acima) é Partida para as fronteiras de um cidadão voluntário, Lesueur. (fig. 14) mostrando o voluntário da família sansculotte.

\footnotetext{
${ }^{55}$ CARBONNIÈRES, Philippe de, Lesueur - Gouaches Révolutionnaires - Collections du Musée Carnavalet, Paris, Paris-Musées, 2005 pp. 100-102.
} 


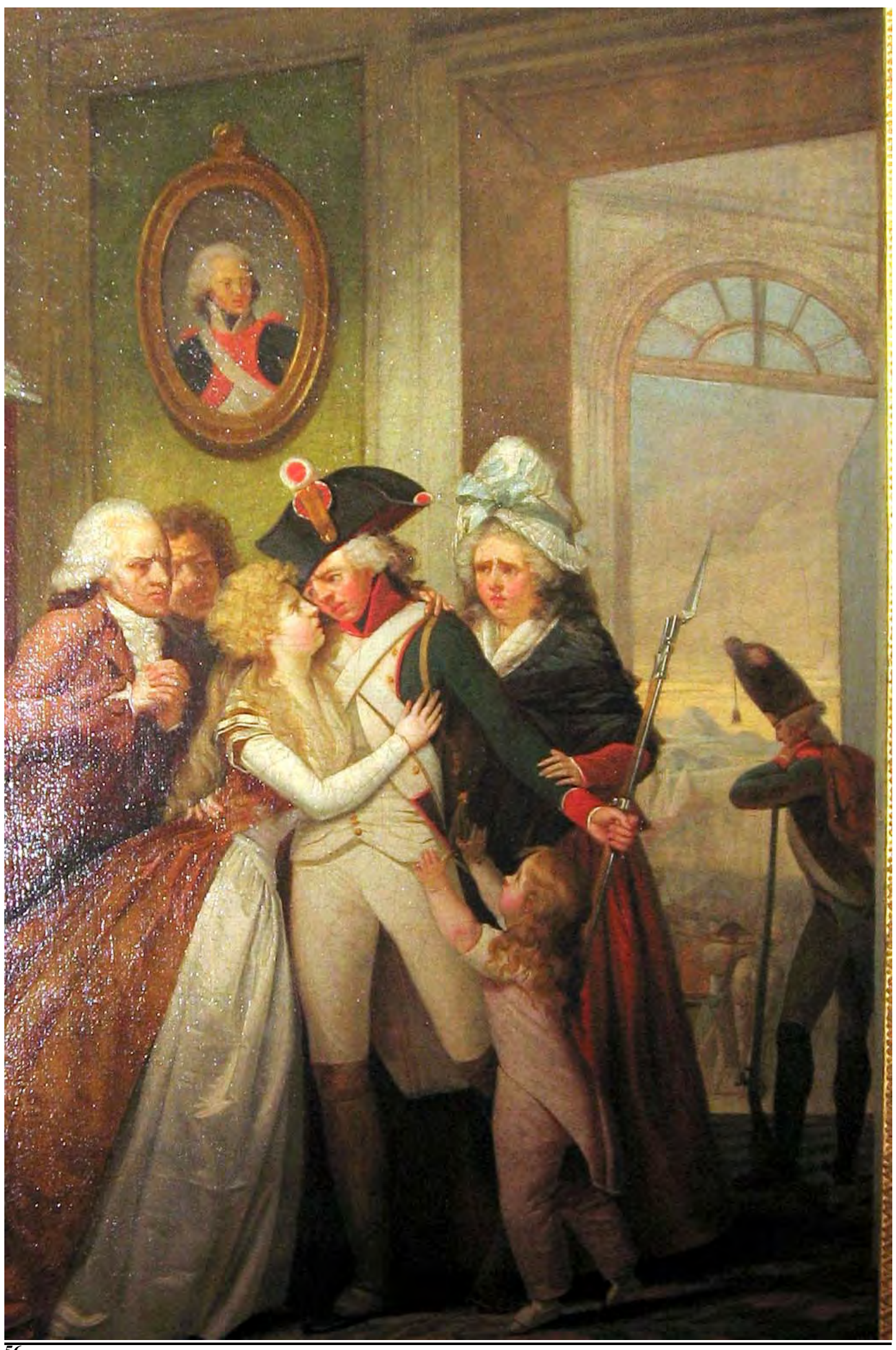

\begin{tabular}{lllllllll}
\hline 56 & Fig & 15 & - & Partida do voluntário & - & Watteau de Lille , & 1792.
\end{tabular}

\footnotetext{
${ }^{56}$ cortesia do Musée Carnavalet, fotografia da autora.
} 
Em 20 de abril de 1792 a França declarou guerra ao Imperador da Áustria, ao qual se aliará em breve o Imperador da Prússia. Depois das primeiras derrotas francesas, em 11 de julho a Assembléia proclamou "a Pátria em perigo" apelando ao alistamento geral. O engajamento dos voluntários se cercou de solenidade, e de um clima de patriotismo fervoroso. Carbonnières acha que Lesueur pintou a aquarela nesse contexto. A figura 12 mostra a partida de um soldado sans-culotte. voluntário compensava a falta de experiência com o entusiasmo para combater "os opressores a soldo dos tiranos". No Antigo Regime o miliciano convocado partia triste e obrigado, mas a Revolução operou uma mudança de mentalidades: os voluntários estavam dispostos a defender a liberdade com seu sangue, daí o voluntário e sua família comemorarem a partida com otimismo. O soldado está cantando, e levantando o braço com o sabre e o chapéu num gesto de vencedor. Sua roupa, principalmente a calça listrada , é a dos sans-culottes. Só o redingote azul, o sabre o e fuzil são os do regulamento: o uniforme completo demorava para chegar e os soldados combatiam com farda improvisada. A mulher do voluntário está de braço dado com ele e ajuda a carregar o fuzil: o republicano sempre tem ao seu lado uma esposa apaixonada . Há uma parente ao fundo levantando uma taça de bebida, celebrando ou desejando boa sorte. O primo serralheiro, sans-culotte de barrete e avental, leva uma garrafa e o embornal com provisões para o militar. O menino entusiasmado dança, levantando o barrete da Liberdade, e olha com orgulho para o pai. A família em geral acompanha o voluntário até a primeira etapa, onde a despedida era mais dolorosa.

Na figura 15, Partida do voluntário - Watteau de Lille, 1792, vemos a despedida de um voluntário da burguesia abastada. A cena de adeus é carregada de emoção: o soldado se despede da mulher com um abraço amoroso. O filho pequeno estende os braços para o pai, o casal mais velho - talvez sogros, ou pais - . também o envolvem com carinho. Na parede, há um retrato de algum ancestral em uniforme, denotando a tradição militar da família. A casa com pé direito alto e vestíbulo na entrada parece ser de família da grande burguesia. O clima da despedida é triste, todos têm o semblante preocupado, o voluntário está deixando para trás pessoas queridas, mas parte decidido para a guerra em defesa da Pátria. Não há muito tempo a perder, o soldado na porta espera para acompanhar o voluntário. 
Os dois trabalhos são da mesma época, mas os voluntários têm atitudes diversas, talvez porque o burguês tivesse mais consciência dos perigos. A sensibilidade é diferente nos dois grupos, mas ambos aceitam a partida do membro da família. Os soldados têm o mesmo ardor patriótico e a mesma determinação, e expressam tal sentimento deixando suas famílias por uma causa maior. Acho que a diferença entre as duas cenas é decorrente das concepções e escolhas artísticas de cada pintor, e não das classes sociais.

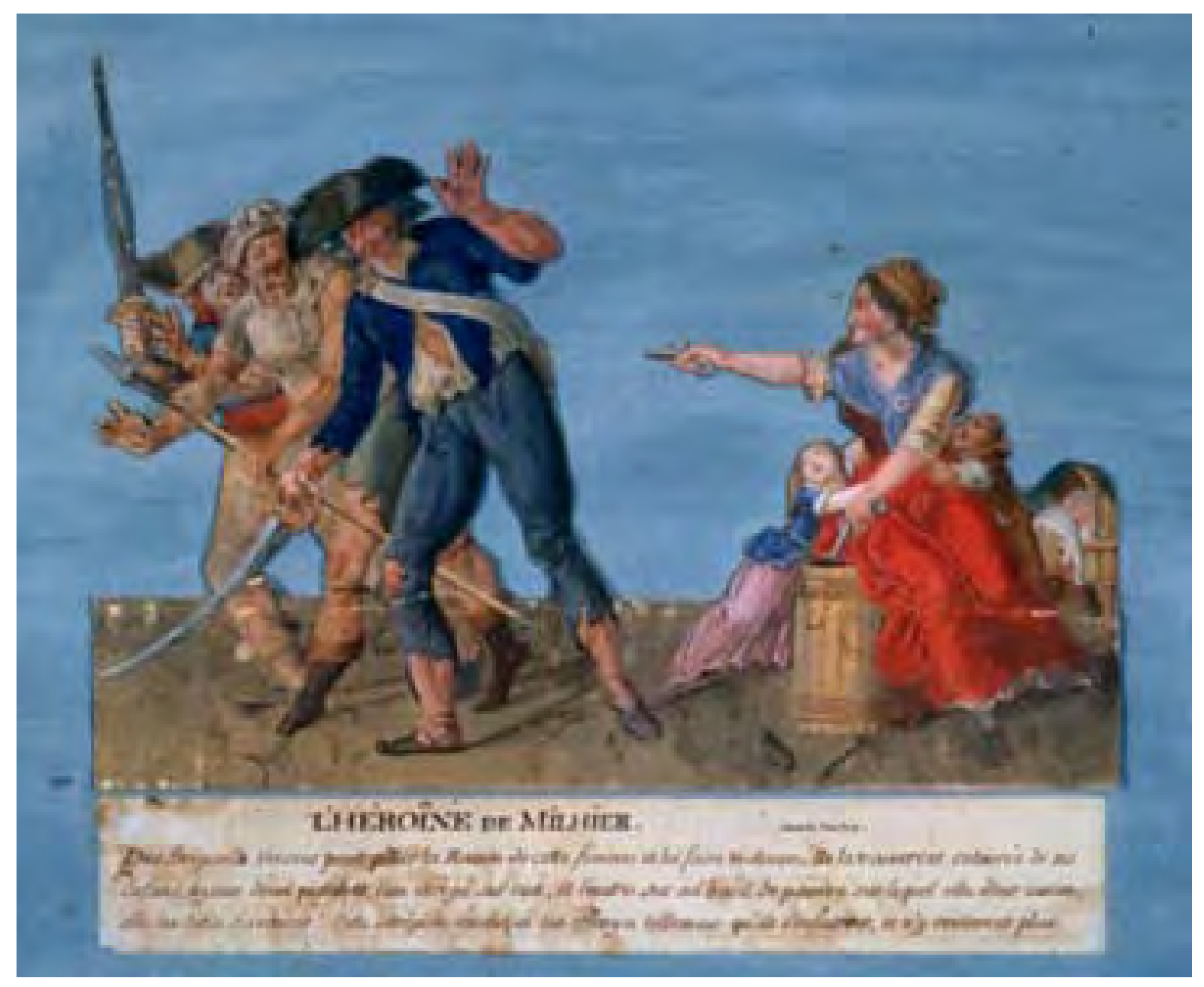

Figura 16 - L'héroine de Milhier - Aquarela de Lesueur, Museu Carnavalet $\underline{57}$

\footnotetext{
${ }^{57}$ CARBONNIÈRES, Philippe de , Lesueur - Gouaches Révolutionnaires - Collections du Musée Carnavalet, Paris, Paris-Musées, 2005 no. 36 , p. 156.
} 
"Na Vendéia, bandidos vieram pilhar a casa desta mulher e fazer-lhe violência. Eles a encontraram rodeada de suas crianças, com duas pistolas, uma apontada na direção deles, e outra apontada para o barril de pólvora sobre o qual ela se sentava e ela os desafiou a avançar! A intrépida decisão os assustou tanto que eles fugiram e não mais voltaram. "

Esta pintura retrata uma cena que supostamente se passou na Vendéia. Entretanto, o historiador Claude Langlois demonstrou que episódio deve ter acontecido em outra região. Michel Vovelle acha que o lugar talvez fosse Chémillé e não Milhier, e lança dúvida sobre a veracidade do ato: " traços de heroísmo anônimos, talvez inventados" ${ }^{58}$. O artista Lesueur, seguindo o exemplo da propaganda oficial, preferiu inscrevê-lo na guerra civil do Oeste. Durante a guerra, os patriotas republicanos , os "bleus" confundiam os combatentes da Vendéia, os "Blancs" e os Chouans, chamando a todos pelo termo pejorativo de "brigands", ou bandidos. Era difícil diferenciar os insurgentes dos bandidos, pois os vendeianos muitas vezes não usavam uniformes. Nesta aquarela, há uma patriota ameaçada por um bando de "Blancs". A heroína de Milhier viu sua casa invadida pelos "bandidos" ou revoltosos da Vendéia e ameaçou dar um tiro no barril de pólvora , explodindo a casa e matando todos, inclusive sua família. Lesueur retratou a mulher com duas pistolas, e três crianças pequenas, uma delas no berço. A cena é dramática, as crianças maiores, um menino e uma menina se agarram à cintura da mãe, apavorados. Os três homens mal-enjambrados têm uma expressão feroz, como quem tem as piores intenções. Usam uma ou outra peça de uniforme esfarrapado, dando realmente a impressão de "brigands". O primeiro abaixou o sabre e tenta se proteger com a mão, atemorizado. A firmeza e a coragem da mulher de Milhier assustaram os invasores, que fugiram. O episódio de Milhier pode ser autêntico, ainda que tivesse acontecido em outro lugar. Foi bastante explorado pela propaganda revolucionária, e reproduzido por vários outros artistas além de Lesueur. Carbonnières considera que a aquarela de Lesueur estaria "bem próxima da realidade", mas ressalta que seria fácil produzir episódios semelhantes de camponesas da Vendéia se defendendo contra os "Bleus", os soldados republicanos ${ }^{59}$. As atrocidades aconteceram em ambos os lados da guerra civil. A pedagogia

\footnotetext{
${ }^{58}$ VOVELLE, Michel, capítulo 7, Les femmes dans la Révolution, La Révolution Française: Images et Récit, 5 vols , Paris CNRS, 1988, p. 271.

${ }^{59}$ CARBONNIÈRES, Philippe de , Lesueur - Gouaches Révolutionnaires - Collections du Musée

Carnavalet, Paris, Paris-Musées, 2005, pp. 155-157.
} 
revolucionária gostava de usar o exemplo das heroínas individuais, principalmente quando eram mártires.

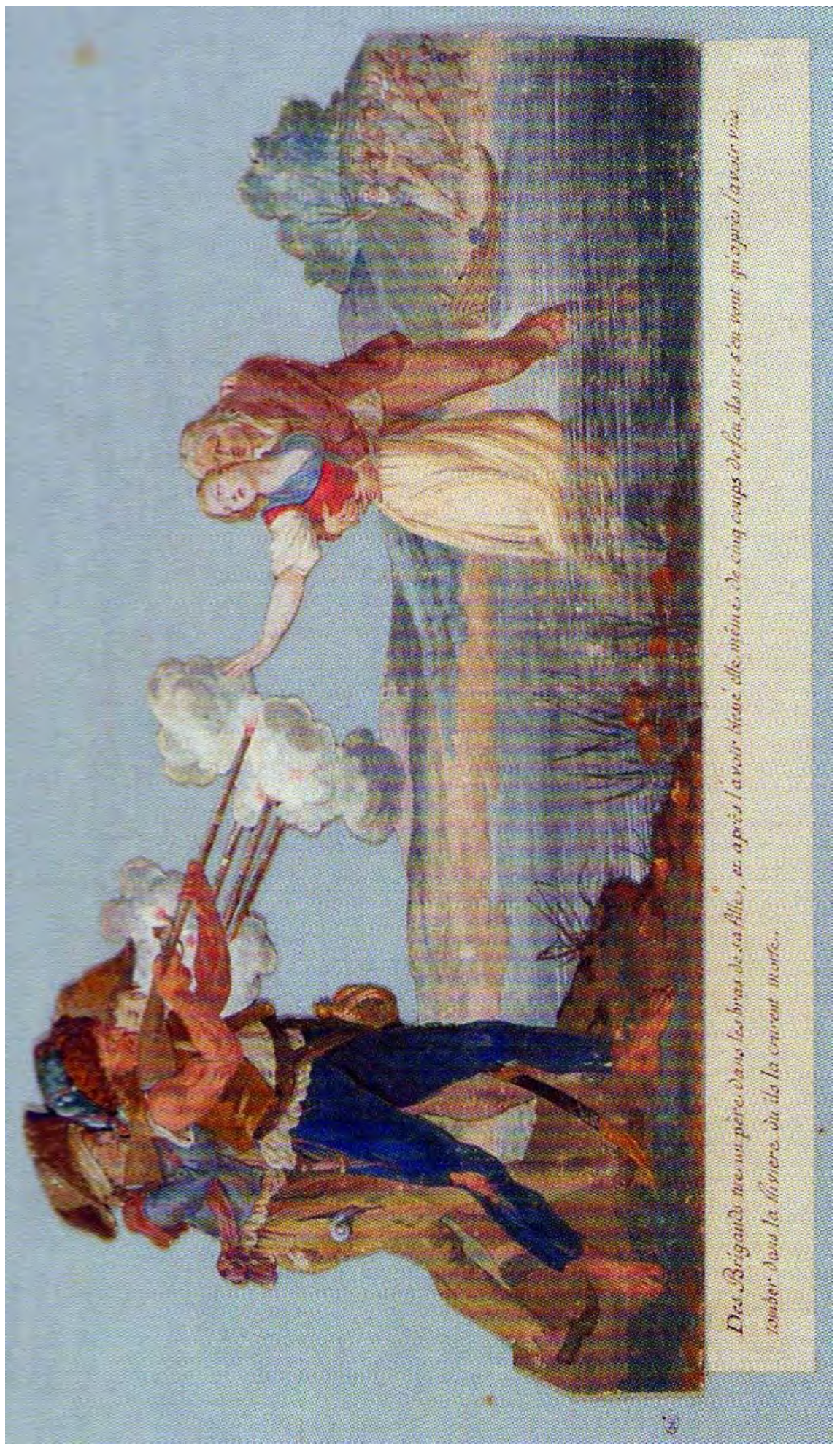

Figura 17 - Os bandidos matam um pai nos braços de sua filha...Louvre RF36538 ${ }^{60}$ Aquarela de Lesueur.

\footnotetext{
${ }^{60}$ CARBONNIÈRES, Philippe de, Lesueur - Gouaches Révolutionnaires - Collections du Musée Carnavalet, Paris, Paris-Musées, 2005, no. 37, p. 160
} 
A Revolução exaltou os seus mártires e existe uma abundante iconografia sobre o tema. A família também foi muito festejada, e em maio de 1794, Robespierre propôs festivais de celebração da fidelidade conjugal, afeição paternal e maternal, piedade filial, infância, juventude e velhice, entre outros. Nada mais apropriado do que criar heróis que unissem duas qualidades, por exemplo, o martírio e a piedade filial. Lesueur era sensível a tais valores revolucionários, como demonstram as várias pinturas dedicadas ao heroísmo de cidadãos e cidadãs comuns. A etiqueta explicativa desta aquarela diz: " Os bandidos matam um pai nos braços de sua filha, e depois de ferirem a moça com cinco tiros, só foram embora quando os viram cair no rio, e pensaram que ela estava morta". A imagem mostra uma cena dramática: um pai cambaleante, apoiando-se na filha que faz um gesto desesperado de defesa e recusase a abandonar o pai. Os atacantes impiedosos atiram nos dois, a aquarela capta o momento da fuzilaria, com fumaça e tudo. Como os "brigands" de Milhier, estes também são esfarrapados, não parecem combatentes e têm "o physique du rôle" de fora-da-lei. Do outro lado do rio, há um grupo de pessoas que agitam os braços e correm, possivelmente querendo salvar o pai e sua filha; o pequeno barco a remo seria o meio de socorrê-los mas não houve tempo. As autoridades assimilavam a delinqüência comum aos opositores do regime republicano. É possível que Lesueur tenha associado o crime aos insurgentes da Vendéia ${ }^{61}$. Como parte da pedagogia cívica, a Convenção Nacional mandou recolher em toda a nação casos de heroísmo, piedade filial (entre outros) para imprimir no Recueil des Actions Héroiques et civiques des Républicains français, no ano II. A publicação seria enviada às municipalidades, aos exércitos, às sociedades populares, a todas as escolas da República, e os relatos seriam lidos publicamente nos Décadis ${ }^{62}$.

Ao mesmo tempo em que se celebravam os casos individuais de heroísmo feminino, havia um outro tipo de participação revolucionária para as mulheres: a cidadania ornamental (fig. 18), incentivada e elogiada pelas autoridades da Revolução.

\footnotetext{
${ }^{61}$ CARBONNIÈRES, Philippe de , Lesueur - Gouaches Révolutionnaires - Collections du Musée Carnavalet, Paris, Paris-Musées, 2005, p. 158.

${ }^{62}$ Recueil... (Presenté à la Convention Nationale au nom de son Comité d"instruction publique, par Léonard Bourdon, an II, Paris, Imprimerie Nationale) microfilme da Bibliothèque Nationale François Mitterrand, Paris.
} 


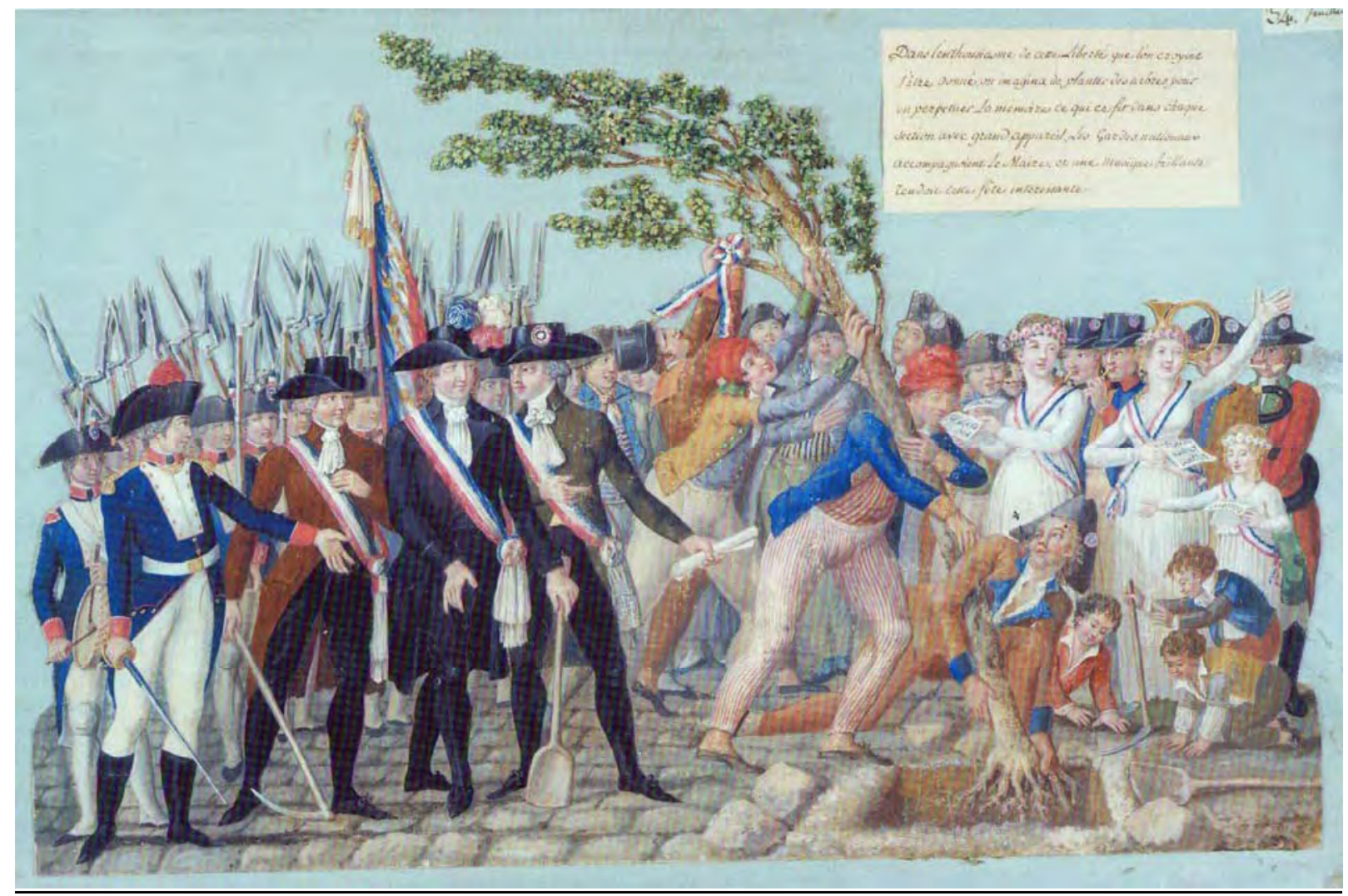

Figura 18 Plantação de uma árvore da Liberdade ${ }^{63}$ Aquarela de Lesueur, Museu Carnavalet.

“Com o entusiasmo desta Liberdade que acreditávamos ter conquistado, imaginamos plantar árvores para perpetuar sua memória, o que se fez em cada seção com grande pompa. Os Guardas Nacionais acompanhavam o Prefeito, e uma música brilhante tornava esta festa interessante"

("Dans l'enthousiasme de cette Liberté que l'on croyoit s"être donné, on imagina de planter des arbres pour en perpétuer la mémoire, ce qui se fit dans chaque section avec grand appareil. Les Gardes Nationaux accompagnoient le Maire, et une Musique brillante rendoit cette fête intéressante”)

Aqui temos um bom exemplo de cidadania ornamental, em que a participação feminina se limita aos aspectos formais e cerimoniais da cidadania, desfilando, cantando, entregando prêmios. A cena acima mostra uma plantação de árvore da Liberdade, que em geral é um carvalho, porque pertencia à tradição gaulesa; além disso, a árvore simbolizava a regeneração no contexto de homenagem à natureza. O poeta e político François de Neufchâteau codificou o cerimonial da plantação: o espírito deveria

\footnotetext{
${ }^{63}$ CARBONNIÈRES, Philippe de , Lesueur - Gouaches Révolutionnaires - Collections du Musée Carnavalet, Paris, Paris-Musées, 2005 fig. No. 11
} 
ser o do consenso e da fraternidade, com participação dos dois sexos. O clero constitucional se encarregava de benzer a árvore - nesta gravura, ele está ausente. A árvore era plantada nas encruzilhadas ou nas praças e simbolizava a liberdade e a igualdade - tornou-se um poderoso símbolo político: de acordo com dois decretos Diretoriais de 1796, quem a mutilasse ou arrancasse era um "inimigo declarado da República" e cometia um crime contra a Revolução ${ }^{64}$. No grupo masculino à esquerda vemos o Prefeito com a pá na mão e as plumas no chapéu, acompanhado de outros oficiais e da Guarda Nacional. Eles têm a circunspecção de seus cargos e autoridade - a parte que cabe aos homens é a administração, a lei e a força. No grupo da direita estão duas jovens mulheres e a menina integrantes do côro: vestidas de branco, cor da pureza, coroa de flores nos cabelos, e faixa tricolor em sinal de patriotismo, elas cantam com entusiasmo, como se depreende pelo gestual. Os músicos tocam em segundo plano - todos usam a cocarda no chapéu. As crianças brincam e "ajudam" a plantar a árvore próximas do grupo acolhedor das mulheres, na ordem natural das relações sociais. Os sans-culottes, com seus barretes frígios da liberdade, suas calças listradas e casacos coloridos fazem o trabalho pesado da plantação com um sorriso nos lábios, como o personagem de paletó bege. Um deles amarra uma cocarda num galho da árvore. A presença de mulheres e crianças dá vida à festa, e simboliza a união da nação em torno do símbolo popular da Revolução. A mensagem da aquarela é que o povo unido apoiava os dirigentes revolucionários, e havia harmonia entre os cidadãos contentes com o novo regime político. Cada um desempenhava seu papel com gosto. Cantar hinos à pátria era considerada uma boa forma de participação feminina nos atos cívicos: elas enfeitavam a festa com sua beleza, alegravam a cerimônia da qual tomavam parte perifericamente, e não ameaçavam as autoridades com reivindicações políticas. Não há data na imagem, mas o texto explicativo deve ser posterior à cena retratada, como é o caso em muitas aquarelas desta série. Os dizeres parecem ter sido escritos depois de 1790, quando aquele primeiro fervor revolucionário já havia passado, e o clima entre os cidadãos era mais pessimista. Vejamos: "o entusiasmo daquela liberdade que acreditávamos haver conquistado" -fica-se com a impressão de que não acreditam mais haver conquistado a liberdade.

\footnotetext{
${ }^{64}$ CARBONNIÈRES, Philippe de, Lesueur - Gouaches Révolutionnaires - Collections du Musée Carnavalet, Paris, Paris-Musées, 2005, pp. 85-86.
} 


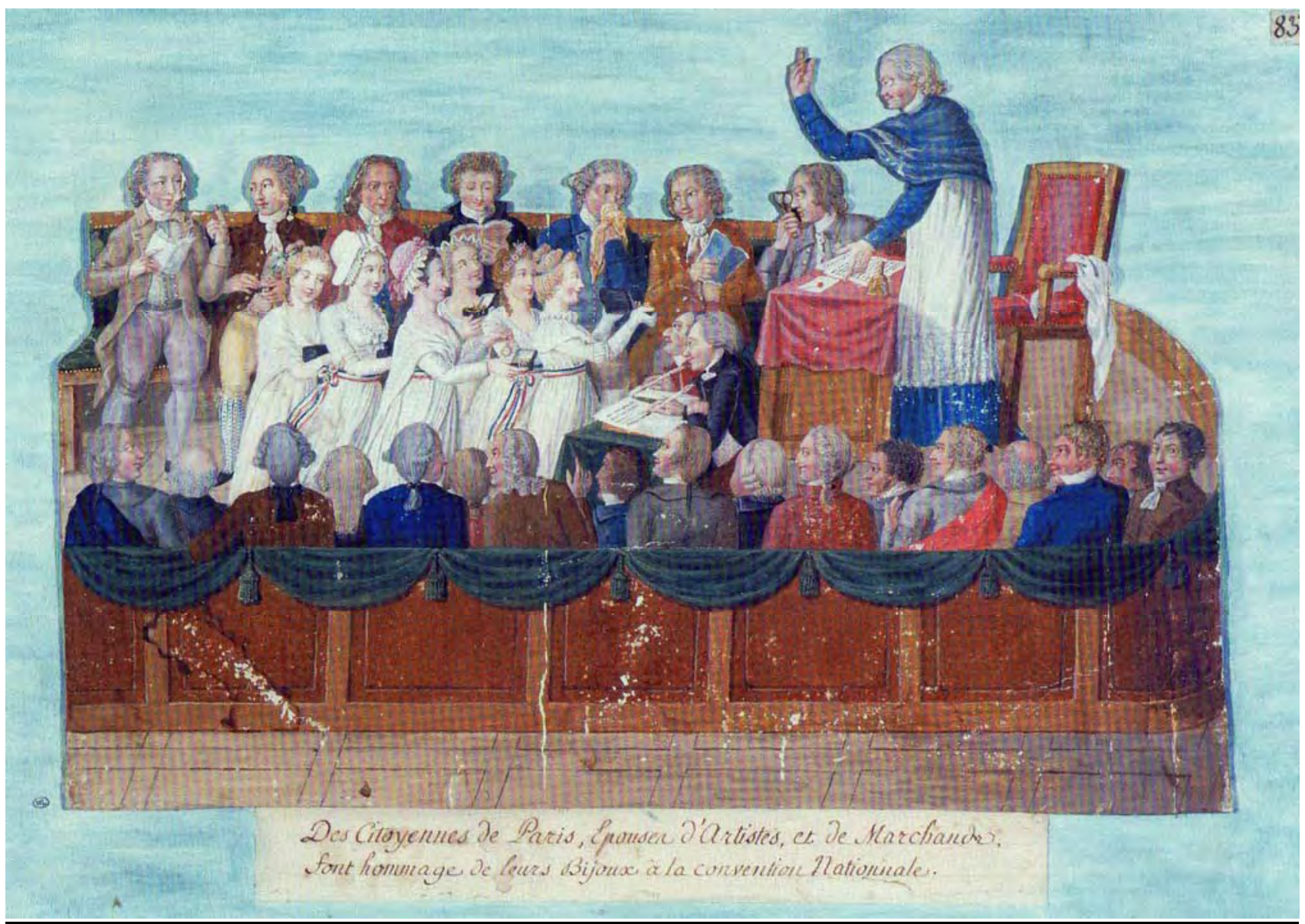

Figura - 19 As cidadãs de Paris, esposas de artistas e de comerciantes fazem a doação de suas jóias à Convenção Nacional. ${ }^{65}$ Aquarela de Lesueur, Museu Carnavalet.

O texto é posterior à realização da aquarela (fig. 19) como acontece em muitas obras dessa coleção. A doação ocorreu em 7 de setembro de 1789, à época da Assembléia Nacional em Versalhes e não da Convenção, que se reuniu só três anos depois. Entre as esposas dos artistas só havia uma comerciante, a cidadã Corne de Cerf. Mais uma vez Lesueur atesta seu interesse pelo sexo feminino, retratando cenas em que as mulheres têm o papel principal. Em geral ele as apresenta numa luz favorável, e desta vez elogia seu espírito público e desprendimento. A dívida nacional era imensa e vários grupos de mulheres doaram seus bens e pertences à nação. Nesta aquarela vemos o momento em que o grupo de mulheres de artistas foi à Assembléia Nacional oferecer suas jóias à pátria. A iniciativa partiu de cento e trinta esposas e filhas de artistas que escolheram onze dentre elas para representá-las. No meio do grupo estão

\footnotetext{
${ }^{65}$ CARBONNIÈRES, Philippe de , Lesueur - Gouaches Révolutionnaires - Collections du Musée Carnavalet, Paris, Paris-Musées, 2005, p.79-80
} 
Madame David, Vien, Fragonard, Lagrenée, Vernet, Gérard, lideradas por Madame Moitte, a qual propôs que se criasse uma caixa especialmente para receber tais doações patrióticas. Alguns deputados seguiram o exemplo e doaram as fivelas de prata de seus sapatos. As cidadãs foram homenageadas com as honras da sessão, e voltaram a Paris acompanhadas por uma multidão exuberante. A maioria delas morava no Louvre, que na época servia de moradia e estúdio dos artistas e suas famílias ${ }^{66}$. Essas mulheres queriam mostrar que eram cidadãs patriotas dispostas a sacrificar os símbolos da vaidade feminina pelo bem comum. Não queriam mais ser identificadas como fúteis e inconseqüentes, como supostamente o eram as aristocratas do Antigo Regime. Por isso o gesto tem o significado importante de ruptura e recomeço. As damas queriam ser lembradas por suas qualidades morais e não pela beleza ou elegância, dentro do espírito revolucionário. A ação filantrópica era uma forma de integrar-se à cidadania. A autora anônima do panfleto "Du sort actuel des femmes" considerou que a exaltação do gesto das beneméritas beirou o exagero - e ponderou que, se aquelas damas demonstraram espírito cívico, foi porque seus maridos eram mais razoáveis que as leis francesas, permitindo mais liberdade às suas esposas. Estas, menos dependentes, tinham mais energia. Se houvesse mais igualdade entre os esposos, outras sairiam de sua apatia para doar jóias como as romanas ${ }^{67}$. Na França revolucionária, a virtude pessoal era também qualidade cívica, da qual se prestava contas à nação, mas era a primeira vez que um grupo de mulheres se apresentava na Assembléia para um ato público de filantropia. O acontecimento um tanto teatral de fato chamou a atenção, foi celebrado e incentivado por aqueles que gostavam da "cidadania filantrópica" para as mulheres. $\quad \mathrm{O}$ jornalista Prudhomme criticou a excessiva desenvoltura feminina: escreveu no seu jornal que elas deveriam ter ficado em casa e enviado as jóias por intermédio dos maridos.

Os vestidos das mulheres eram os habituais para cerimônias patrióticas: modelo simples, todo branco, cingido por uma fita tricolor na cintura, ou seja, o único enfeite era o símbolo patriótico. Para cidadãs sérias, era o suficiente. A simplicidade denotava o despojamento da aparência e da alma. O clérigo que preside a sessão as abençoa. Alguns deputados parecem prestar atenção no oferecimento das mulheres, mas outros

\footnotetext{
${ }^{66}$ CARBONNIÈRES, Philippe de , Lesueur - Gouaches Révolutionnaires - Collections du Musée Carnavalet, Paris, Paris-Musées, 2005, pp. 79-80.

${ }^{67}$ Cahiers de doléances des femmes en 1789 et autres textes - préfacé par Paule-Marie Duhet Paris, C. Des femmes 1981 , p. 122.
} 
conversam, dois lêem, e alguns exibem um sorriso condescendente ou mesmo irônico. Pelas expressões dos rostos, parece que julgaram o gesto feminino enternecedor, mas ingênuo e talvez de pouca utilidade. Para as mulheres, entretanto, simbolizou o pertencimento à nação e a prática da cidadania consciente. Além de Lesueur, vários outros artistas registraram a cena para a posteridade.

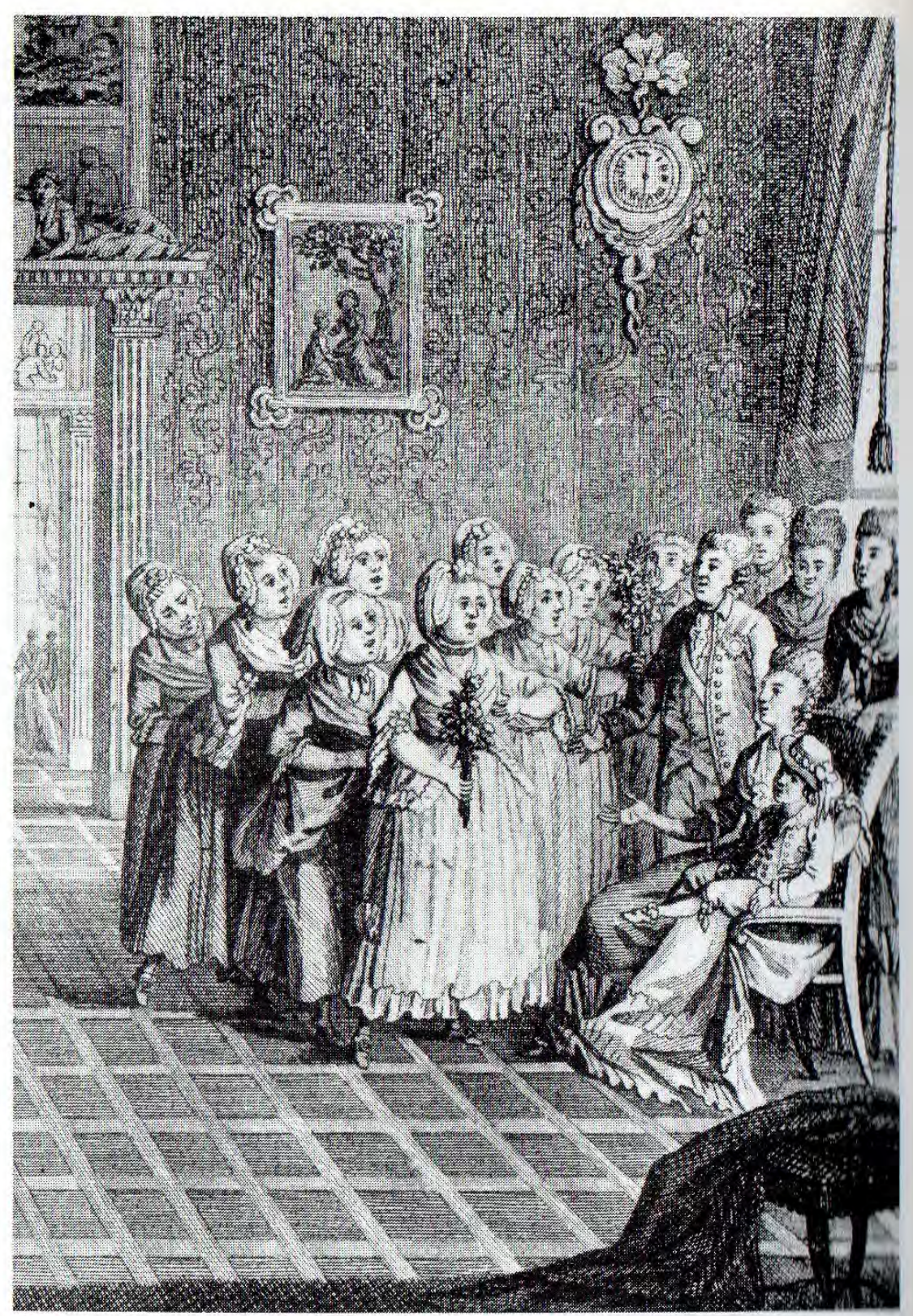

Figura 20 - "Vendedoras do mercado (Dames de la Halle) parabenizando suas Majestades pelo início da Constituição" outubro $1789^{68}$ - Gravura anônima. Museu Carnavalet.

\footnotetext{
${ }^{68}$ MARAND-FOUQUET, Catherine, La femme au temps de La Révolution - 1989, Éditions Stock/Laurence Pernoud. imagem no. 18 e índice p. 410.
} 